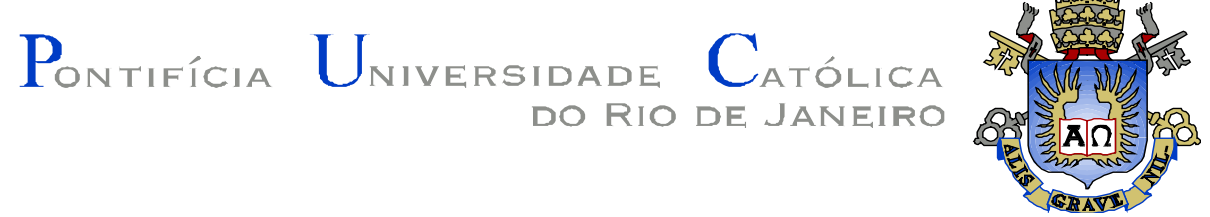

Maracy Domingues Alves

\title{
Sofrimento Psíquico do Trabalho: \\ Construção de um instrumento para o diagnóstico de penosidade
}

Tese de Doutorado

Tese apresentada ao Programa de Pós-graduação em Psicologia da PUC-Rio como requisito parcial para obtenção do grau de Doutor em Psicologia Clínica

Orientadora: Prof ${ }^{a}$. Terezinha Féres-Carneiro Co-orientador: Prof. Daniel Mograbi

Rio de Janeiro abril de 2019 
Pontifícia Universidade C Católica

\title{
Maracy Domingues Alves
}

\section{Sofrimento Psíquico do Trabalho: Construção de um instrumento para o diagnóstico de penosidade}

\begin{abstract}
Tese apresentada como requisito parcial para obtenção do grau de Doutor pelo Programa de Pós-Graduação em Psicologia (Psicologia Clínica) da PUC-Rio. Aprovada pela Comissão Examinadora.
\end{abstract}

Profa. Terezinha Féres-Carneiro

Orientadora Departamento de Psicologia - PUC-Rio

Prof. Daniel Correa Mograbi Co-orientador Departamento de Psicologia - PUC-Rio

Profa. Andrea Seixas Magalhães Departamento de Psicologia - PUC-Rio

Profa. Maria Helena Rodrigues Navas Zamora

Departamento de Psicologia - PUC-Rio

Profa. Rita Maria Manso de Barros

UNIRIO

Profa. Claudia Osório da Silva Departamento de Psicologia- UFF

Rio de Janeiro, 05 de abril de 2019. 
Todos os direitos reservados. É proibida a reprodução total ou parcial do trabalho sem autorização da universidade, da autora, da orientadora e do co-orientador.

\section{Maracy Domingues Alves}

Graduação e Licenciatura em Psicologia (Universidade Católica de Santos), Especialização em Psicologia Social (PUC-Pr) e Mestrado em Psicologia Social e da Personalidade (Fundação Getúlio Vargas - RJ). Estudos no Doutorado em Psicologia Social das Organizações no Instituto Superior de Ciências do Trabalho e da Empresa - ISCTE da Universidade de Lisboa. Certificada Lean Six Sigma no grau Green Belt. Professora do Departamento de Psicologia da PUC-Rio. Professora do curso de Psicologia da Universidade Católica de Petrópolis - UCP.

Ficha Catalográfica

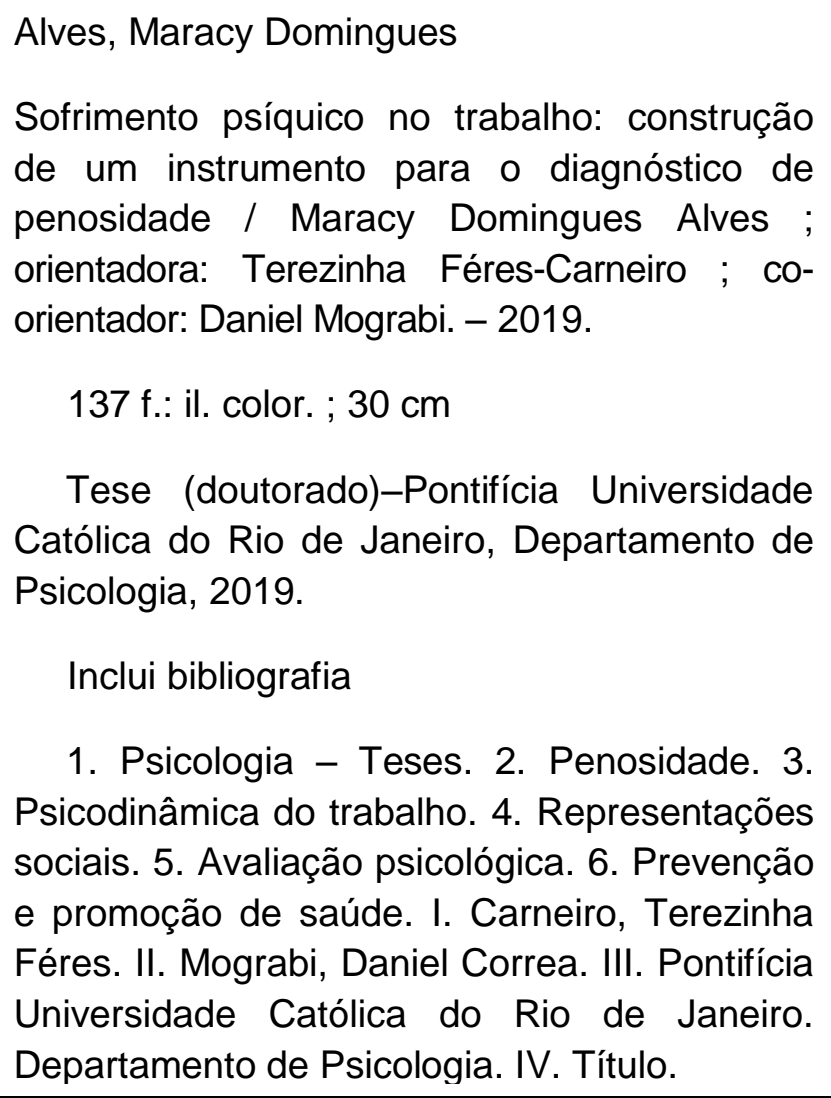

1. Psicologia - Teses. 2. Penosidade. 3. Psicodinâmica do trabalho. 4. Representações sociais. 5. Avaliação psicológica. 6. Prevenção e promoção de saúde. I. Carneiro, Terezinha Féres. II. Mograbi, Daniel Correa. III. Pontifícia Universidade Católica do Rio de Janeiro. Departamento de Psicologia. IV. Título. 
Para Ellen e Yghor, meus filhos. 


\section{Agradecimentos}

Ao Departamento de Psicologia da Pontifícia Universidade Católica do Rio de Janeiro, pelo ambiente de estudos e trabalho e financiamento do curso de doutorado.

Ao Ministério da Saúde, Programa PET Saúde - Redes de Atenção a Urgência e Emergência, pelo financiamento da pesquisa.

Ao Centro de Ciências Biológicas e da Saúde da Pontifícia Universidade Católica do Rio de Janeiro, pelo patrocínio do Projeto PET Saúde - Redes de Atenção a Urgência e Emergência.

Ao Hospital Municipal Miguel Couto, pela permissão de coleta de dados e, em especial aos funcionários da Emergência pelo gentil acolhimento para responder aos itens do instrumento.

Aos preceptores do projeto PET Saúde - Redes de Atenção a Urgência e Emergência, representantes do Hospital Municipal Miguel Couto, pela parceria agradável e eficaz durante o período do projeto.

Aos queridos estagiários da graduação em Psicologia da Pontifícia Universidade Católica do Rio de Janeiro pelo trabalho conjunto, alegre e companheiro, durante o PET Saúde - Redes de Atenção a Urgência e Emergência.

À orientadora Terezinha Feres Carneiro e ao co-orientador, Daniel Mograbi, pela carinhosa e assertiva orientação na tese.

Ao colega Rodrigo Leão pelo apoio nas análises estatísticas.

À Andrea Magalhães e Flávia Solero pelo encaminhamento e encorajamento para o processo seletivo de ingresso no Programa de Doutorado.

À Rita Manso, pelos ricos anos de convívio no ambiente acadêmico e na alegria dos anos de amizade desde o curso de mestrado e, por ter me apresentado às ideias de Christophe Dejours.

À Junia de Vilhena pelo coleguismo acadêmico, pela possibilidade de submissão de publicações e amizade na vida.

À Maria Helena Zamora, pela amizade e discussões acaloradas sobre o Bem Comum.

À banca desta tese, pela paciência na leitura e contribuições ao trabalho.

Aos colegas professores dos cursos de psicologia da Pontifícia Universidade Católica do Rio de Janeiro e da Universidade Católica de Petrópolis pela convivência cotidiana nas lides docentes.

Aos meus alunos que, ao longo dos últimos anos, participaram no processo ensino-aprendizagem das discussões sobre a qualidade da experiência no trabalho relacionada à penosidade.

Aos colegas de turma do doutorado, pelas discussões nas disciplinas e seminários.

À Lilian Marques pelo apoio e leal companhia durante o trabalho. 


\section{Resumo}

Alves, Maracy Domingues; Féres Carneiro, Terezinha; Mograbi, Daniel. Sofrimento psíquico no trabalho: Construção de um instrumento para o diagnóstico de penosidade. Rio de Janeiro, 2019. 134p. Teses de Doutorado - Departamento de Psicologia, Pontifícia Universidade Católica do Rio de Janeiro

Com base na Psicodinâmica do Trabalho e na Teoria das Representações Sociais, apresentam-se a criação e verificação da qualidade psicométrica do instrumento, Inventário para Avaliação de Penosidade - IAP. O conceito de Vita Activa de Hanna Arendt é articulado com uma discussão sobre o mundo do trabalho, enfatizando que é necessário relevar os aspectos psicológicos tanto quanto os aspectos do corpo no trabalho. O objetivo geral desta investigação é construir e validar um instrumento para diagnóstico do sofrimento psíquico relacionado ao trabalho e investigar as representações sociais de tal sentimento. O instrumento tem como propósito a identificação das dificuldades encontradas no desempenho da função que possivelmente levam ao sofrimento psíquico tais como: falta de familiaridade do profissional com as técnicas e conhecimentos relativos ao seu trabalho; sua percepção em relação à autonomia no trabalho; os limites concernentes às adversidades de sua ocupação profissional. São objetivos específicos: definir indicadores mensuráveis de penosidade com base nas dimensões descritas na Psicodinâmica do Trabalho e nos níveis de representação propostos na Abordagem Societal das Representações; verificar a qualidade psicométrica do instrumento; e investigar as representações sociais de sofrimento psíquico em relação ao trabalho. $\mathrm{O}$ delineamento foi baseado em estudo exploratório-descritivo com abordagem quali-quantitativa. A pesquisa foi realizada na emergência de hospital público, no município do Rio de Janeiro, com entrevistas realizadas com 249 funcionários. Concluiu-se que a percepção de sofrimento psíquico está relacionada à autonomia na realização do trabalho e a quanto, como e até quando o sujeito pode suportar este tipo de sofrimento.

\section{Palavras-chave}

1.Psicologia 2. Penosidade. 3. Psicodinâmica do Trabalho. 4. Representações Sociais. 5. Avaliação Psicológica. 6. Prevenção e promoção de saúde. 


\section{Abstract}

Alves, Maracy Domingues; Féres Carneiro, Terezinha; Mograbi, Daniel. Psychological suffering at work: Construction of an instrument for the diagnosis of painfulness. Rio de Janeiro, 2019. 137p. Tese de Doutorado Department of Psychology, Pontifical Catholic University of Rio de Janeiro

Based on the Psychodynamics of Work and Social Representation Theory, the creation and verification of the psychometric quality of the instrument is presented, Inventory for Evaluation of Penosity (IAP). Hanna Arendt's Concept of Active Vita is articulated with a discussion of the world of work, emphasizing that it is necessary to emphasize psychological aspects as much as aspects of the body at work. The general objective of this research is to construct and validate an instrument for the diagnosis of psychological suffering related to work and to investigate the social representations of such feeling. The purpose of the instrument is to identify the difficulties encountered in the performance of the function that may lead to psychological distress such as: lack of familiarity of the professional with the techniques and knowledge related to their work; their perception of autonomy at work; the limits concerning the adversities of their professional occupation. Specific objectives are: to define measurable indicators of painfulness based on the dimensions described in the Psychodynamics of Work and at the levels of representations proposed in the Societal Approach of Representations; verify the psychometric quality of the instrument; and to investigate the social representations of psychic suffering in relation to work. The design was based on an exploratory-descriptive study with a qualitative-quantitative approach. The research was carried out in the emergency of a public hospital, in the city of Rio de Janeiro, with interviews with 249 employees. It is concluded that the perception of psychic suffering is related to the autonomy in the accomplishment of the work and how much, how and until when the subject can endure this type of suffering. 


\section{Sumário}

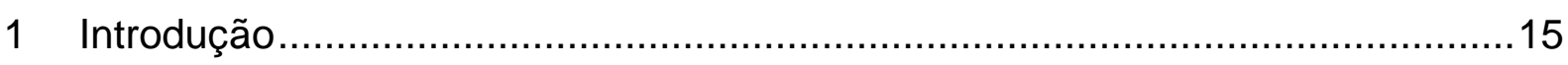

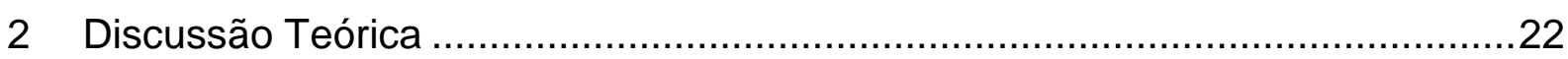

2.1 Vita activa: sofrimento no corpo c'alma ....................................................22

2.2 Mundo do trabalho em tempos sombrios …….............................................34

2.3 Sobre Psicodinâmica do Trabalho e Representações Sociais. ........................53

2.3.1 Psicodinâmica do Trabalho: Burnout e estratégias de defesas. ...............53

2.3.2 Subjetividade e representações .....................................................56

2.3.3 Representações sociais e engendramento de instituintes ........................71

2.3.4 Dimensões e Níveis de Representação no sofrimento psíquico

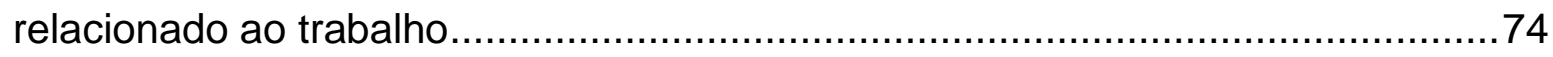

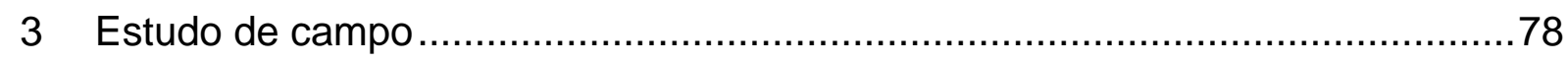

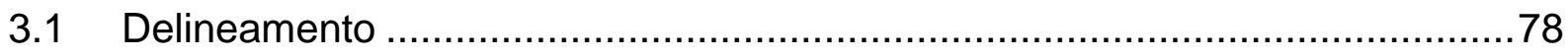

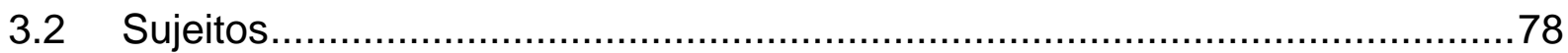

3.3 Instrumento

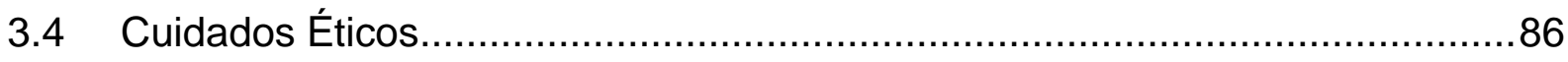

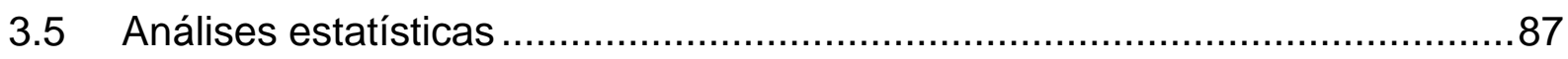

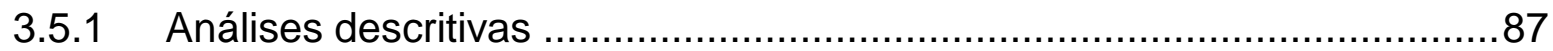

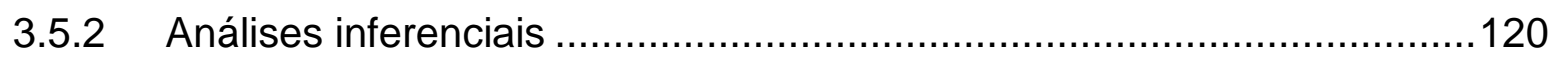

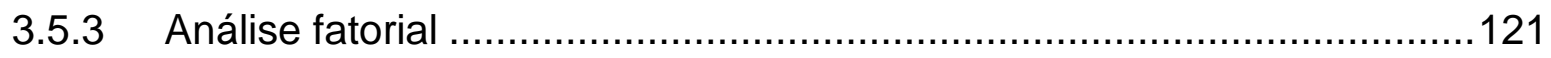

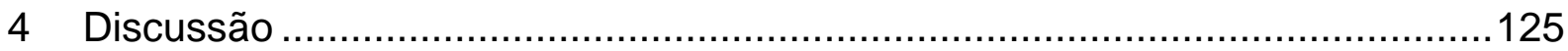

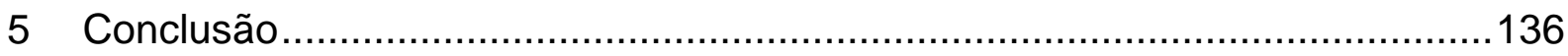

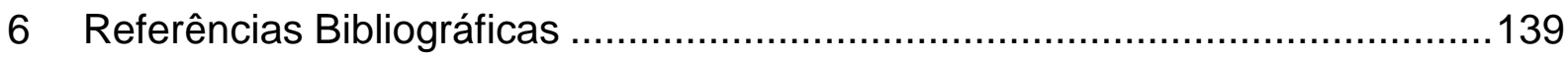




\section{Lista de Figuras}

Figura 1 - dimensões e níveis de representações para análise do sofrimento psíquico no trabalho humano, segundo dejours e sato, e moscovici e doise

Figura 2 - protocolo de entrevista sobre sofrimento psíquico no trabalho .86

Figura 3 - matriz de esforço-impacto para tomada de decisões 135 


\section{Lista de Quadros}

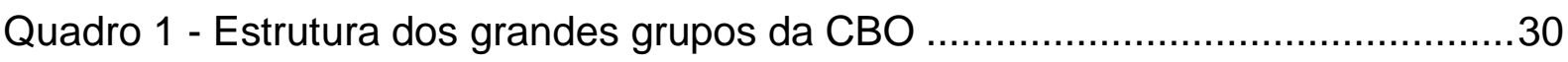

Quadro 2 - Identificação de responsáveis - caso Aurora .......................................36

Quadro 3 - Projeção da população ativa no brasil ................................................39

Quadro 4 - Comparação entre população urbana e rural por região -

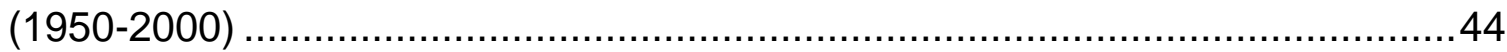




\section{Lista de Gráficos}

Gráfico 1 - Taxa de desemprego no brasil (2004-2016) .....................................39 gráfico 2 - Percentual de crescimento da população por região/década -

(1950-2000)

gráfico 3 - Penosidade funcionários do hospital municipal miguel couto -

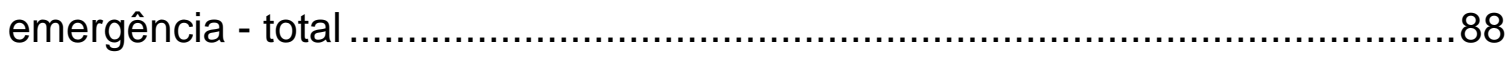

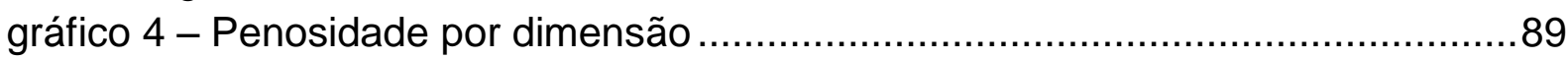

gráfico 5 - Penosidade por nível de representação ………...............................90

gráfico 6 - Penosidade por dimensão/nível de representação................................91

gráfico 7 - Penosidade responsabilidade da ocupação gg/cbo - total .....................92

gráfico 8 - Penosidade responsabilidade da ocupação gg2/cbo máximo

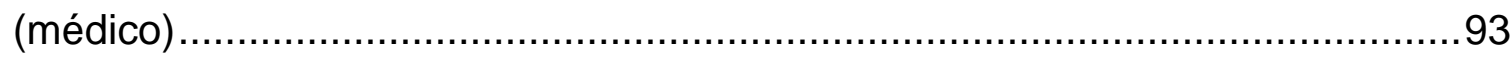

gráfico 9 - Penosidade responsabilidade da ocupação gg2/cbo altíssimo

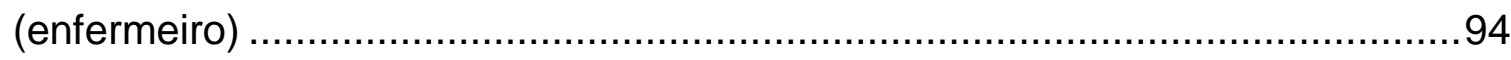

gráfico 10 - Penosidade responsabilidade da ocupação gg2/cbo alto

(assistente social, dentista, fonoaudiólogo, nutricionista, psicólogo) ..................95

gráfico 11 - Penosidade responsabilidade da ocupação gg3/cbo

médio/alto (técnico de enfermagem)

gráfico 12 - Penosidade responsabilidade da ocupação gg3/cbo médio

(instrumentista cirúrgico, técnico gessista, técnico em radiologia,

secretária)

gráfico 13 - Penosidade responsabilidade da ocupação gg4/cbo

médio/baixo (auxiliar administrativo e recepcionista)

gráfico 14 - Penosidade responsabilidade da ocupação gg5/cbo baixo

(auxiliar de serviços gerais, copeiro, gari, maqueiro, segurança,

vigilante)

gráfico 15 - Penosidade responsabilidade da ocupação sem código/cbo

mínimo (acadêmico e estagiário)....

gráfico 16 - Penosidade responsabilidade do setor de alocação - total ..................100

gráfico 17 - Penosidade responsabilidade do setor de alocação - alta

(centro cirúrgico, sala vermelha e sala amarela)

gráfico 18 - Penosidade responsabilidade do setor de alocação - média

(consultório nefrologia, consultório ortopedia, consultório pediatria,

multi consultório, multi salas, regulação, radiologia e sala verde)

gráfico 19 - Penosidade responsabilidade do setor de alocação - baixa

(esterilização, consultório bucomaxilo, consultório otorrinolaringologia,

farmácia, recepção, salas/ consultórios) 103

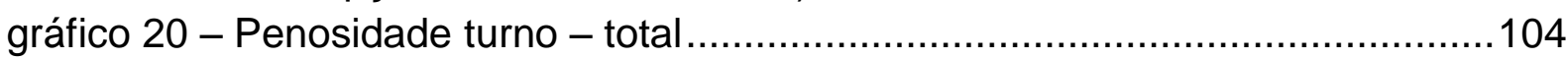

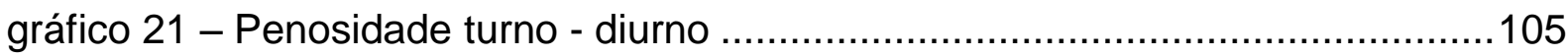

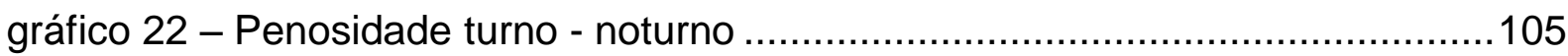

gráfico 23 - Penosidade turno - diurno/noturno..................................................106

gráfico 24 - Penosidade escala - total............................................................107 
gráfico 25 - Penosidade escala - diarista .................................................... 108

gráfico 26 - Penosidade escala - plantonista ...............................................108

gráfico 27 - Penosidade escala - dupla matrícula ...........................................109

gráfico 28 - Penosidade sexo - ambos .......................................................110

gráfico 29 - Penosidade sexo - feminino .................................................... 110

gráfico 30 - Penosidade sexo - masculino .................................................... 111

gráfico 31 - Penosidade faixa etária - total ...................................................112

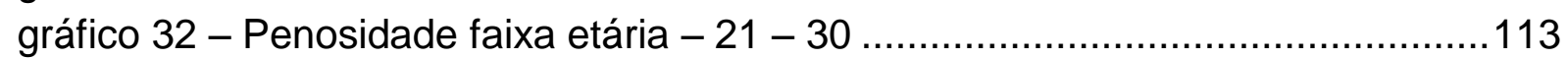

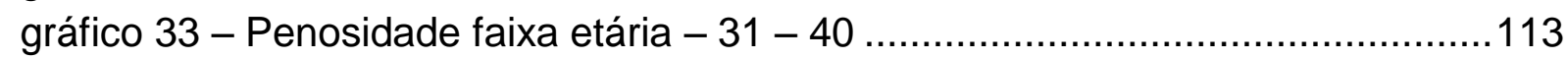

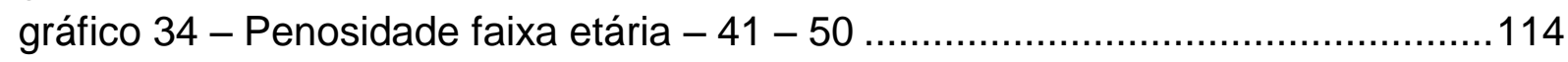

gráfico 35 - Penosidade faixa etária -51 - mais............................................... 114

gráfico 36 - Penosidade tempo na ocupação - to, por dimensão e nível de representação .................................................................................... 115

gráfico 37 - Penosidade tempo em emergência - te, por dimensão e nível

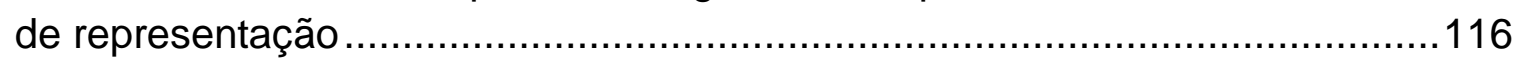

gráfico 38 - Penosidade tempo no hospital municipal miguel couto -

thmmc, por dimensão e nível de representação ........................................117

gráfico 40 - Penosidade moradia núcleo ........................................................118

gráfico 41 - Penosidade responsabilidade financeira núcleo familiar .....................119

gráfico 42 - Anova dimensão / nível de representação......................................121

gráfico 43 - Scree plot parar análise dos eigenvalues.....................................124 


\section{Lista de Tabelas}

Tabela 1 - Pessoas sem proteção do sst - mte (2012-2017)

Tabela 2 - Ocupações nos grandes grupos cbo e nível de responsabilidade

Tabela 3 - Setor de alocação na emergência - nível de responsabilidade .82

Tabela 4 - Turno, escala, sexo e faixa etária..... .83

Tabela 5 - Tempo na ocupação, tempo na emergência, tempo no hmmc e tempo na emergência dohmmc .84

Tabela 6 - Moradia/núcleo familiar . .85

Tabela 7 - Matriz padrão. 124 
Aventurar-se causa ansiedade, mas deixar de arriscar-se é perder a si mesmo. Soren Kierkegaard 


\section{Introdução}

Nas suas considerações, ou reconsiderações, sobre angustia, dor e tristeza, Freud (1925) reconhece que

"nosso conhecimento dos processos afetivos é tão reduzido que as tímidas observações que a seguir serão expostas não deverão ser submetidas a um julgamento muito severo. (...) Contentar-nos-emos, pois com precisar alguns contornos do problema e achar alguma orientação nova". (Freud, 1925/1973, p.317)

É uma constatação que remete à discussão sobre a possibilidade do conhecimento científico, sobretudo os relacionados à Psicologia, levar ao acesso ao mundo externo, somente por inferências. O conceito de senso comum desenvolvido pelos filósofos da Grécia antiga partiu do princípio que o acesso à realidade externa sempre é limitado pelos órgãos sensoriais, que são comuns a todas as pessoas. Por essa razão, qualquer teoria que busque testar empiricamente seus pressupostos fatalmente tem limitações. Um dos principais ganhos no início da filosofia foi a busca de explicações para fenômenos naturais. Explicações metafísicas ou religiosas foram descartadas e surgiram conceitos que, de alguma forma poderiam potencializar o grau de explicação para os fenômenos humanos a partir de conhecimento científico. Para contornar as limitações do senso comum, é necessária a construção de instrumentos que permitem o acesso indireto ao mundo empírico, não apenas para testar teorias, mas, sobretudo, para a aplicação deste conhecimento a aspectos relacionados à vida cotidiana. A principal limitação dos erros metodológicos está relacionada com a natureza do instrumento. Esta questão é particularmente importante na área da Psicologia. Isto porque os instrumentos que visam a acessar de forma indireta a atividade mental de uma pessoa (ou a realidade psicológica) apresentam grandes limitações. Por esta razão, deve-se certificar de que o instrumento psicológico apresenta um mínimo de propriedades psicométricas, tais como Fidedignidade e Validade.

Estudar o sofrimento psíquico se insere nesta dificuldade. Rocha (2011) estuda as etapas principais da elaboração freudiana da teoria metapsicológica da dor, tanto na sua dimensão física quanto psíquica. Em seu trabalho, o autor aponta que Freud escreve sobre a vivência da dor (Schmerzerlebnis), que está relacionada aos sistemas de neurônios phi, psi e ômega e à condição de desamparo 
(Hilflosigkeit) do recém-nascido e, também, sobre a experiência de satisfação originária. No que se refere ao desamparo, a interpretação de Rocha é a de que Freud "utilizou a sugestiva palavra alemã Hilflosigkeit, que, no seu sentido etimológico, quer dizer precisamente a situação na qual alguém se encontra sem nenhuma possibilidade de poder ajudar a si mesmo. A palavra Hilfe quer dizer ajuda e Losigkeit significa a falta de ou a ausência de alguma coisa" (p. 601). De fato, sem a ajuda de um outro diferente de si, não há sobrevivência. Sobre a vivência de satisfação, a discussão freudiana, no estudo de Rocha (2011), se refere ao aparelho psíquico do recém-nascido que, para eliminar a fonte de estímulo de insatisfação endógena, busca desfazer a tensão pelo grito ou choro como signos de apelo. E, sendo assim, uma necessidade orgânica e vital demanda uma expressão de comunicação.

Na explicação sobre angústia, dor e tristeza, Freud (1925/1973) aponta que, embora inicialmente tenha definido que a angústia estivesse relacionada ao perigo da perda do objeto, considerou necessário incluir a tristeza e a dor como parte da explicação. E, ainda assim, segundo ele, não se esgotará a necessidade de explicação sobre quando a separação do objeto produz angústia, tristeza ou dor. Como ponto de partida, Freud (1925/1973) exemplifica uma situação do lactente que encontra uma pessoa estranha em lugar de sua mãe. Para ele, é indiscutível que a criança experimenta angústia nesta situação. Mas, “além disso, a expressão de sua fisionomia em tais momentos e seu pranto fazem supor que também sente dor” (p. 317). São necessárias várias experiências consoladoras para dirimir este estado até que se instale a experiência de anelo (Sehnsucht) com a mãe. Esse processo demonstra que a primeira condição de angústia é a perda de percepção, que Freud compara com perda do objeto. As repetidas experiências de satisfação permitem a carga de anelo. A dor surge de um órgão interno com representações associadas ao terreno psíquico. “A representação do objeto altamente carregada pela necessidade desempenha o papel de lugar do corpo intensamente carregado pelo aumento de estímulo. A continuidade do processo de carga e a impossibilidade de impedi-lo dão origem ao mesmo estado de impotência psíquica.” (p. 320). A tristeza advém da constatação da perda do objeto.

Para além das postulações freudianas sobre sofrimento psíquico, Dejours (2015) articula suas ideias sobre o sofrimento psíquico relacionado ao trabalho, à insatisfação e ao conteúdo significativo da tarefa. Para ele, o trabalho impacta a 
atividade psíquica. E esse impacto é maior quando destituído de atividade intelectual. "Entre a organização do trabalho e o aparelho mental desapareceu amortecedor que constituía até aí a responsabilidade de concebeu de realizar a tarefa em função de Know-how, isto é, a atividade intelectual engajada pelo operário-artesão no seu trabalho.” (p. 53). O autor se refere ao período da implantação taylorista no modelo de gestão. Para ele, o corpo, no período prétaylorista, atuava com base no pensamento, controlado pelo aparelho psíquico que é o lugar do prazer e dos afetos. Assim, a organização do trabalho, despersonalizante, faz emergir o sofrimento psíquico. E como lidar com esse sofrimento psíquico relacionado ao trabalho?

Para Dejours (2015) os trabalhadores podem recorrer a defesas individuais, que, no entanto, segundo ele, não são eficazes e o sofrimento se agrava. Seu argumento é o de que "até indivíduos dotados de uma sólida estrutura psíquica podem ser vítimas de uma paralisia mental induzida pela organização do trabalho" (p. 56). Quanto mais a organização do trabalho for rígida, menor a possibilidade de que ao trabalho seja possível associar conteúdo significativo, e menores as possibilidades de mudá-lo. E, desta forma, o sofrimento aumenta. A ergonomia, como ciência aplicada, é uma tentativa de minimizar essa característica. Mas não tem sido suficiente. Acrescenta-se aí um componente importante referido às condições em que o trabalho organizado se insere. Entretanto, ainda assim, o conhecimento e adaptação do trabalho, às condições em que ele é realizado, não proporciona a vivência subjetiva dos seus atores. Nem a área da Saúde Ocupacional e nem as denúncias sobre as contradições do sistema dominante oriundas da área da Saúde do Trabalhado tratam, efetivamente, da integração entre os objetivos dos trabalhadores e os das organizações de trabalho em essência. Há, historicamente, uma luta polarizada no escopo de ideias entre as duas áreas.

Acredita-se que o trabalho é organizado dentro de uma estrutura definida pelo Estado que, por sua vez, é constituído pelos valores desdobrados da mentalidade do mercado mundial. Nesse sentido, se impõe uma análise que vá além das oposições entre empregador e empregado, ou ainda entre empregador e forma de produção vigente do Estado. É preciso, portanto, compreender quais os valores que integram o substrato das diversas ideologias e, sobretudo, de que forma estes valores, construídos coletivamente, também, constroem a realidade no 
mundo do trabalho. Desta forma, será possível tentar certo nível de explicação para o estudo do sofrimento psíquico relacionado ao trabalho. Se essa explicação for obtida pela "voz" dos atores principais, os trabalhadores, acredita-se possível propor intervenções que se constituam como estratégias defensivas coletivas.

A Constituição Brasileira no seu artigo $7^{\circ}$, que define os "direitos dos trabalhadores urbanos e rurais, além de outros que visem à melhoria de sua condição social", no seu inciso XXIII prevê adicional de remuneração para as atividades penosas da mesma forma que aquelas insalubres e perigosas. A definição desse adicional de penosidade refere-se à modalidade de indenização destinada a todo tipo de atividade que, embora não cause efetivo dano à saúde do trabalhador, cause sofrimento psíquico, desde que não percebam qualquer outro adicional.

O surgimento desta figura jurídica relacionada à saúde psíquica do trabalhador tem origem na Lei Orgânica 3.807 de 1960 da Previdência Social. Foram consideradas atividades penosas: funções de magistério; funções relativas ao transporte rodoviários, como motoristas e cobradores de ônibus; funções com operações industriais que trazem desprendimento de poeiras capazes de fazerem mal à saúde, incluindo os trabalhos permanentes no subsolo e os trabalhos permanentes em galerias, rampas, poços, depósitos etc. Com a Lei, também da Previdência Social, 7.850 de 1989, a atividade de telefonista, também passa a ser definida como penosa. Entretanto, com as Leis 8.212/91, 8.213/91 e o decreto 3.048/99, estas atividades penosas desapareceram para a concessão da aposentadoria especial, mas passaram por jurisprudência a ter seu entendimento com base no artigo 57 da Lei 8.213/91, “A aposentadoria especial será devida, uma vez cumprida a carência exigida nesta Lei, ao segurado que tiver trabalhado sujeito a condições especiais que prejudiquem a saúde ou a integridade física, durante 15 (quinze), 20 (vinte) ou 25 (vinte e cinco) anos, conforme dispuser a lei." Interpreta-se em decorrência que como as atividades penosas são prejudiciais à saúde do trabalhador, deverão também ser incluídas neste rol alvo da jurisprudência.

A partir do conhecimento sobre o grau de sofrimento psíquico relacionado ao trabalho, é possível realizar uma atuação preventiva e criar mecanismos para minimizar o estresse do trabalhador, melhorar a saúde ocupacional e buscar formas de intervenção que possibilitam a melhoria das condições de trabalho. 
Segundo o Manual Técnico de Promoção da Saúde e Prevenção de Riscos e Doenças na Saúde Suplementar, publicado pela Agência Nacional de Saúde Suplementar (2009) "Os primeiros conceitos de promoção da saúde foram definidos pelos autores Winslow, em 1920, e Sigerist, em 1946. (...) Posteriormente, Leavell e Clark, em 1965, delinearam o modelo da história natural das doenças, que apresenta três níveis de prevenção: primária, secundária e terciária. "(Agência Nacional de Saúde Suplementar, 2009, p.17). A promoção de saúde, como movimento, surgiu no Canadá em 1974, com o documento "A new perspective on the health of canadians" (Informe Lalonde). Supondo que as principais causas de morbimortalidade no Canadá estavam relacionadas à biologia humana, ao meio ambiente e ao estilo de vida, o Informe Lalonde propõe cinco estratégias no campo da saúde: promoção da saúde, regulação, eficiência da assistência médica, pesquisa e fixação de objetivos. Esse documento foi precursor da I Conferência Internacional sobre Cuidados Primários de Saúde, em 1978, abrindo espaço, também, para o evento promotor da Carta de Ottawa, em 1986, a I Conferência Internacional sobre Promoção da Saúde. De acordo com esse documento, a promoção de saúde não é responsabilidade somente dos profissionais de saúde. Prevê o estilo de vida saudável para o bem-estar global e inclui os aspectos socioculturais, econômicos e ecológicos. Por outro lado, ao definir ações preventivas, o Manual, indica que são "intervenções orientadas a evitar o surgimento de doenças específicas, reduzindo sua incidência e prevalência nas populações. (...). A prevenção orienta-se às ações de detecção, controle e enfraquecimento dos fatores de risco de enfermidades, sendo o foco a doença e os mecanismos para atacá-la”. (Agência Nacional de Saúde Suplementar, 2009, p.18)

Erdmann et al (2006) discutiram a gestão das práticas de saúde considerando o ser humano como um ser de cuidado, mas que, ao mesmo tempo é responsável por suas ações. Com esta visão, sob a perspectiva do cuidado complexo realizado por equipes de saúde, os autores apontam para a necessidade de promoção da saúde e da valorização da vida e respeito a diversidade humana. Como ser do cuidado e ator das práticas de saúde, o usuário do sistema de saúde deve participar ativamente no exercício da sua autonomia e na luta dos seus direitos. Sendo assim, o trabalhador do sistema de saúde interage com usuários ativos e detentores do uso de voz em reivindicações. Neste sentido, a gestão das 
práticas de saúde envolve o contato com a diversidade humana, reconhecendo igualdades e diferenças instituídas, em nível biológico, social, político e cultural.

A gestão do cuidado e a gestão de qualidade são temas fundamentais quando se procura analisar as questões referidas ao sofrimento psíquico de trabalhadores. Os estudos sobre gestão do cuidado inserem-se no tema das relações humanizadas e da atuação de equipes multidisciplinares que, ultrapassando as questões estritamente biológicas, atentam para as noções de integralidade, acolhimento e vínculo como fundamentais para a qualidade da gestão do cuidado. Entretanto um dos pontos exaltados na atualidade é a aplicação de Gestão da Qualidade nas instituições de saúde brasileiras. Assim, compreendendo, de forma sistematizada, o trabalho humano nas diversas ocupações será possível definir indicadores mensuráveis de penosidade. E, em sequência, torna-se concreta a minimização dos estressores com base na elaboração de plano de ação específico.

O tema do sofrimento psíquico no trabalho interessa para a Psicologia, no que se refere ao efetivo desenvolvimento de atividades vinculadas à atenção de saúde como preconizado nas Diretrizes Nacionais de Psicologia. Neste sentido, os profissionais devem estar aptos a desenvolver ações de prevenção, promoção, proteção e reabilitação da saúde psicológica e psicossocial. Com base nas mesmas Diretrizes, no que se refere aos processos de gestão, este projeto tem relevância no que tange ao "uso de procedimentos e técnicas específicas voltadas para analisar criticamente e aprimorar os processos de gestão organizacional, em distintas organizações e instituições" (Resolução n5, de 15 de março de 2011, p. 4) Outro aspecto relevante deste projeto, refere-se à aplicabilidade do diagnóstico nos processos clínicos, sobretudo, como base para a Clínica da atividade proposta por Clot (2006).

A pesquisa sobre penosidade é importante para identificar as dificuldades encontradas no desempenho da função que possivelmente leva à insatisfação do profissional e, em decorrência ao sofrimento psíquico. Dentre elas, podemos citar: falta de familiaridade do profissional com as técnicas e conhecimentos relativos ao seu trabalho; sua percepção em relação à autonomia no trabalho; os limites concernentes às adversidades de sua ocupação profissional. Quantificar as dificuldades que, eventualmente, levam à insatisfação do trabalhador, a partir de 
dados qualificáveis coletados no seu cotidiano de trabalho trará, sem dúvida, conhecimentos importantes para a área da saúde do trabalhador.

Além disso, por ter indicadores mensuráveis por métricas confiáveis, configura-se como argumentação para resgatar os pressupostos da Lei Orgânica 3.807 de 1960 da Previdência. Assim, a promoção de saúde psíquica de trabalhadores poderá ser embasada como figura de Lei assemelhada às Leis 8.212/91, 8.213/91 ao invés da fundamentação em jurisprudência conforme o artigo 57 da Lei 8.213/91. Com o instrumento, será possível verificar o grau de penosidade de cada ocupação ou família de ocupações que estão descritas na Classificação Brasileira de Ocupações - CBO do Ministério do Trabalho e do Emprego- MTE. Com as informações obtidas pelo instrumento, também será possível consubstanciar as convenções propostas pela Organização Internacional do Trabalho - OIT e ratificadas pelo Brasil. Desta forma, esta pesquisa pretende, com seu produto final, garantir o diagnóstico do sofrimento psíquico no trabalho que o caracterize como penosidade. E sendo assim, com seus indicadores quantitativos, possibilitará que a gestão do cuidado programe intervenções específicas na saúde do trabalhador, por meio de políticas públicas ativas e passivas.

Em face deste cenário, o objetivo geral desta investigação é construir e validar um instrumento para diagnóstico do sofrimento psíquico relacionado ao trabalho e investigar as representações sociais de tal sentimento. São objetivos específicos: definir indicadores mensuráveis de penosidade com base nas dimensões descritas na Psicodinâmica do Trabalho e nos níveis de representações propostos na Abordagem Societal das Representações; verificar a qualidade psicométrica (fidedignidade e validade) do instrumento; e investigar as representações sociais de sofrimento psíquico em relação ao trabalho; 


\section{Discussão teórica}

\subsection{Vita activa: sofrimento no corpo c'alma}

Na visão de Arendt (1991), labor, trabalho e ação são as três atividades que correspondem às condições básicas "mediante as quais a vida foi dada ao homem na Terra" (ARENDT, 1991, p.15). O labor se refere ao processo biológico do corpo humano e sua condição é a vida. O trabalho é a atividade criada pelo homem e sua condição humana é a mundanidade. A ação está relacionada à pluralidade e tem caráter político. Vita activa, então, na interpretação de Arendt com inspiração aristotélica, equivale à expressão grega askholia (ocupação, desassossego).

Cabe aqui uma ampliação da etimologia da palavra askholia. Wagner (2002) aponta a crítica de Hannah Arendt e Karl Marx tratando a vita activa como valorização da vida, o labor como o trabalho na sociedade moderna e a ação como fabricação na política marxista. E, culmina definindo a sociedade utópica como um lugar de contradições. Do texto de Wagner (2002) busca-se a ampliação do conceito trazido por Arendt em sua apresentação da condição humana. Na interpretação de Wagner em relação ao pensamento aristotélico, vita activa não incluía as atividades relacionadas à fabricação de objetos com fins de sobrevivência. Entretanto, não havia nesta visão uma ênfase da vita activa em contraposição à vita contemplativa. Na primeira, activa, havia uma conotação negativa porque estaria associada a in-quietude ou a-skholia. Na interpretação de Wagner (2002),

O primado da contemplação sobre a atividade baseia-se na convicção de que nenhum trabalho de mãos humanas pode igualar em beleza e verdade o Kosmos físico, que revolve em termo de si mesmo em imutável eternidade, sem qualquer interferência ou assistência externa, seja humana ou divina, do ponto de vista da contemplação. Não importa o que perturba a necessária quietude; o que importa é que ela seja perturbada" (WAGNER, 2002, p.56)

De acordo com Silva (2014) askholia é do mesmo étimo do grego skholé, que originou schola em latim e escola em português e, é quase um sinônimo de nec otium, que originou negócio, descanso ocupado. $\mathrm{O}$ a de askholia indica negação. 
O descanso ocupado vislumbra que seja retomado o estudo de Arendt (1991) sobre a condição humana, iluminando-se a sua discussão da localização das atividades humanas no que tange às esferas pública e privada. A autora propõe uma distinção entre labor e trabalho discutindo "o labor do nosso corpo e o trabalho de nossas mãos" (ARENDT, 1991, p.90). Na sua interpretação há coincidência etimológica em todas as línguas europeias, antigas e modernas, entre labor e trabalho, o que os torna, contemporaneamente como sinônimos, sobretudo no senso comum.

Assim, a distinção de Locke entre as mãos que trabalham e o corpo que labora é, de certa forma, reminiscente da antiga distinção grega entre o cheirotechnes, o artífice, ao qual corresponde o handwerker alemão, e aqueles que, como escravos e animais domésticos, atendem com o corpo às necessidades da vida - ou na expressão grega, to somati ergazesthai, trabalham com o corpo. (ARENDT, 1991, p.90)

A conotação negativa destes termos advém do fato de que as necessidades da vida na polis grega eram supridas pelos artesãos que, envolvidos em seus ofícios na esfera privada, não se dedicavam à esfera pública. Sendo assim, essa ideia permeou a classificação das ocupações, hierarquizando-as com base na quantidade de esforço que cada uma exige. Neste sentido, o significado de laborar, na antiguidade, estava associado a "ser escravizado pela necessidade, escravidão esta inerente às condições da vida humana" (ARENDT,1991, p.94) Além disso, do cheirotechnes surge a mentalidade do homo faber.

Ao discutir os instrumentos do trabalho e a divisão do labor, Arendt (1991) questiona:

Parece ser da natureza das condições da vida, tal como esta foi dada ao homem, que a única vantagem possível da fertilidade da humana força de trabalho (labor power) consista em sua capacidade de prover as necessidades da vida de mais de um homem ou de uma família. Os produtos do labor, produtos do metabolismo do homem com a natureza, não duram no mundo o tempo suficiente para se tornarem parte dele, e a própria atividade do labor, concentrada exclusivamente na vida e em sua manutenção, é tão indiferente ao mundo que é como se não existisse. O animal laborans, compelido pelas necessidades do corpo, não usa esse corpo livremente como o homo faber utiliza as mãos, que são os seus instrumentos primordiais;(ARENDT, 1991, p.130).

E, como isso remete a vita activa em sua condição humana?

É preciso relembrar as definições arendtianas das atividades inerentes às condições básicas da vida humana, considerando a indissolubilidade entre elas. A síntese destas definições está calcada nos três binômios já referidos inicialmente: 
labor/vida; trabalho/mundanidade; ação/pluralidade que se entrelaçam pelo caráter político. Desse caráter político decorre a ideia de que o trabalho humano tem sua divisão oriunda do agir conjunto no percurso da vida e, isso ocorre dentro de estruturas de organização política. Nesse percurso transcendem-se os processos da própria vida e "a vitalidade e o vigor só podem ser conservados na medida em que os homens se disponham a arcar com o ônus, as fadigas e as penas da vida" (ARENDT, 1991, p.133). Na sequência desta ideia a constatação é a de que todo o trabalho precisa de instrumentos para a sua produção. $\mathrm{O}$ surgimento do homo faber e das coisas do mundo feita pelos homens é coetâneo à criação, também pelo homem, de instrumentos e ferramentas, justamente para amenizar este ônus do corpo. Na interpretação de Arendt (1991), embora as ferramentas e instrumentos minimizem o sofrimento em termos de esforço e dor, "não mudam a necessidade em si; servem apenas para escondê-la de nossos sentidos". (ARENDT, 1991, p.137)

E as condições de existência na mentalidade brasileira? ${ }^{1}$

O tema deste texto é o trabalho humano e seu sofrimento relacionado. Portanto, remete-se à importância do estudo do fenômeno de nosso tempo e do nosso lugar. Defende-se, aqui, a ideia de que a pesquisa em Psicologia, sem deixar o interesse pela pesquisa básica, deve ser revestida de função política. Sendo assim, buscou-se fontes em alguns autores clássicos, que para além do estudo histórico fatual, propõem suas análises críticas com base no substrato de ideologias, viés da história das mentalidades. Assim, Jaguaribe (1986), Oliveira Vianna (1974) e Penna (1989) apontam para o aforismo fica o que significa.

No estudo histórico da democracia brasileira, Jaguaribe (1986) apresenta uma democracia de notáveis, instaurada por Pedro I e que perdurou durante o Império e a República Velha até que a Revolução de 1930 modificou as relações de poder e conduziu a uma democracia de classe média, transformando-se, com Vargas numa democracia de massas. Refere-se aos latino-americanos como o grupo onde existem maiores contradições entre ideais e atos. E, aponta como determinante deste fenômeno, o fato de tais países tomarem emprestados o

\footnotetext{
${ }^{1}$ Recorre-se aqui à visão da História das mentalidades como área de estudos permeável com as Representações Sociais, conforme mostra Vovelle (1987) "dentro dessa alquimia (...) podemos ver, em uma extremidade, o insumo sociológico e, na outra, o produto conforme se expressa nas atitudes e comportamentos." (VOVELLE, 1987, p. 113)
} 
parlamentarismo da Inglaterra, a democracia da França e o presidencialismo dos Estados Unidos, esperando que produzam os mesmos resultados, decorrendo daí, discordâncias acentuadas entre normas e comportamentos, num conflito entre cultura do povo-massa e das elites. O Brasil, na análise de Jaguaribe, está no rol das nações com esse traço.

Oliveira Vianna (1974) descreve, minuciosamente, o processo de colonização dos principais estados do Brasil, citando nominalmente as famílias, para mostrar que o grupo familiar crescia por contiguidade. Sugere que a solidariedade familiar e a formação de clãs parentais são decorrência desse processo, somado a necessidade de união para proteção dos perigos. Ressalta, porém, que esta solidarização é peculiar e exclusiva à classe senhorial. Indica que os clãs parentais intervêm frequentemente no nosso direito público e na nossa história política, principalmente nos conflitos intervicinais e nos motins contra as autoridades ou guerras contra o estrangeiro. Conclui a análise do clã parental mostrando que a democratização por decreto, em 1822, que instituiu o sufrágio universal, contraditoriamente, recaiu sobre este tipo de sociedade, qual seja, dispersa, incoesa e de estrutura aristocrática.

Penna (1989) prioriza a análise dos fatos e mudanças importantes dentro da história republicana, procurando ressaltar a participação do povo neste processo, sobretudo dos grupos sociais organizados da sociedade, dando uma maior ênfase na apreciação dos grupos de pressão que atuaram de forma decisiva nos acontecimentos. Entre os marcos que assinalam o regime republicano no Brasil segundo Penna (1989), é o da ditadura e populismo do Estado Novo. Enfatiza o papel da Aliança Nacional Libertadora, frente à política dos segmentos de esquerda, da Ação Integralista Brasileira na década de 1930. A coetânea Carta de 1937, como fundamento do Estado Novo e das leis trabalhistas, é o ponto central da análise.

Esse tema é retomado por Kerscher (1990) que apresenta uma análise das representações sociais pelo Exército Brasileiro sobre a República brasileira, justamente na época em que se comemorava o centenário de sua proclamação em 1989. Utilizando como quadro teórico a História das Mentalidades e a Teoria das Representações Sociais, a pesquisa analisou os documentos denominados Ordens do Dia que, sob a responsabilidade de líderes da corporação foram produzidos nos cem anos da instauração desse regime no Brasil, entre 1889 e 1989, considerando 
que estes personagens da história da república brasileira foram considerados, não coadjuvantes, mas figuras centrais neste cenário. Esta pesquisa foi realizada com a permissão da instituição, nos arquivos do Palácio Duque de Caxias. Foram 37 documentos analisados, sendo 20 com autoria registrada no próprio documento e 17 sem registro de autoria no documento, mas que, como comandantes em chefe da corporação, respondiam por seu conteúdo. Nos demais 63 anos de comemoração, não houve alusão à efeméride. A análise privilegiou as ideias de ordem, progresso, segurança e desenvolvimento, que foram articuladas com as ideologias que dominaram as conjunturas republicanas durante os 100 anos alvo. Os resultados demonstraram a associação aos conceitos de soldado-cidadão, aos quais não se poderia negar o direito de participar na vida política do país; o soldado-profissional, considerando que sendo missão do Exército a defesa nacional, com consequente afastamento de participação direta ou indireta na política; e, o soldado-corporação em que se admitia aberta intervenção na política sem a abstenção da preparação profissional em prol da defesa nacional.

Após esse período muitos movimentos sociais e políticos engendraram a vita activa no país, na medida em que impactaram o desenvolvimento econômico e social. Em 2017, em que o tema produtividade volta ao ápice das discussões da economia, as garantias das lides do trabalho e da quietude dos aposentos estão em pauta com propostas de reformas que, em atropelo para votação nas várias instâncias face à grave crise institucional, privilegiam não o trabalho do homo faber ou sua quietude posterior, mas o labor do animal laborans em constante quietude do alto de seus nec otium.

Retoma-se aqui o estudo de Arendt (1991) especificamente sobre o trabalho como uma das três atividades da condição humana. Releve-se sua discussão sobre os instrumentos no âmbito do animal laborans e do homo faber. Nesta análise parte do pressuposto que os instrumentos essenciais do homo faber são as suas mãos. E que os instrumentos que aliviam a carga e automatizam o labor do animal laborans são criados e produzidos pelo homo faber. O desenvolvimento da tecnologia tem forte impacto nessa premissa. Sendo assim, Arendt (1991) descreve os três principais estágios de desenvolvimento da tecnologia desde o início da era moderna. 
Como primeiro momento, aponta o advento da invenção da máquina a vapor em que a tecnologia apenas ampliava o vigor das mãos humanas com o uso da energia alimentada por minas de carvão.

O segundo momento apresentado pela autora mostra o início do uso da eletricidade que resultou em mudança de paradigma na medida em que altera o conceito de fabricação de estanque em contínuo porque

As categorias do homo faber, para quem todo instrumento é um meio de atingir um fim prescrito, já não se aplicam. Pois agora já não usamos material tal como a natureza o fornece, matando processos naturais, interrompendo-os ou imitando-os. (...) alteramos e desnaturalizamos a natureza para nossos próprios fins mundanos, de sorte que o mundo ou o artifício humano, de um lado, e a natureza, de outro, passam a ser duas entidades nitidamente separadas (ARENDT, 1991, p. 161).

O terceiro e último momento é caracterizado pela automação que existe de forma auto propelida e neste sentido já não mais se configura como "produto de um esforço humano consciente no sentido de multiplicar a força material, mas sim uma evolução biológica da humanidade" (ARENDT, 1991, p.166).

A conclusão de Arendt (1991) é que, em decorrência deste desenvolvimento da tecnologia, homo faber e animal laborans deixam de compreender a própria razão final porque, enquanto os primeiros, por ser um fabricante de coisas, e o segundo por ser incapaz de dar significado ao conceito de instrumento, perdem o seu próprio valor intrínseco.

No que tange à terceira atividade da condição humana, a ação, o estudo da autora aponta para a pluralidade humana como condição básica da ação e do discurso: "no homem, a alteridade, que ele tem em comum com tudo o que existe, e a distinção, que ele partilha com tudo o que vive, tornam-se singularidade, e a pluralidade humana é a paradoxal pluralidade de seres singulares" (ARENDT, 1991, p.189). Sendo assim, através do discurso e da ação os seres humanos se manifestam, não como objetos físicos, mas c' alma.

Na era moderna, surpreende-se Arendt (1991), não se produziu teoria sobre a distinção entre o labor do nosso corpo e o trabalho de nossas mãos. As polarizações no pensamento da época e, é possível pensar que mesmo na visão contemporânea, estão definidas em três binômios: trabalho produtivo e improdutivo; trabalho qualificado e não qualificado; e, trabalho manual e intelectual. 
No Brasil contemporâneo essa realidade também se manifesta na Classificação Brasileira de Ocupações - CBO que é o documento normalizador do reconhecimento, da nomeação e da codificação dos títulos e conteúdo das ocupações do mercado de trabalho brasileiro. É ao mesmo tempo uma classificação enumerativa que codifica empregos e outras situações de trabalho para fins estatísticos de registros administrativos, censos populacionais e outras pesquisas domiciliares. Inclui códigos e títulos ocupacionais e a descrição sumária; e, uma classificação descritiva que faz um inventário detalhado das atividades realizadas no trabalho, os requisitos de formação e experiência profissionais e as condições de trabalho.

A CBO foi, inicialmente, elaborada em 1977, resultado do convênio firmado entre o Brasil e a Organização das Nações Unidas - ONU, por intermédio da Organização Internacional do Trabalho - OIT, tendo como base a Classificação Internacional Uniforme de Ocupações - CIUO de 1968. Entre 1994 e 2002 houve necessidade de reestruturação, realizada em parceria entre o Ministério do Trabalho e do Emprego - MTE e o Instituto Brasileiro de Geografia e Estatística IBGE, em função de atualização da CIUO. Para a sua elaboração, o MTE contou com a colaboração voluntária de sindicatos de trabalhadores, patronais, empresas e sete mil trabalhadores que participaram dos painéis de descrição das 596 famílias ocupacionais que compõem o documento, cobrindo 2.422 ocupações e 7.258 títulos sinônimos.

Essa versão da CBO permanece em vigência desde então. Como base conceitual, duas definições são utilizadas: ocupação e competência. Ocupação é um conceito sintético não natural, artificialmente construído pelos analistas ocupacionais. O que existe no mundo concreto são as atividades exercidas pelo cidadão em um emprego ou outro tipo de relação de trabalho. O conceito de competência tem duas dimensões: nível de competência, entendida como função da complexidade, amplitude e responsabilidade das atividades desenvolvidas no emprego ou outro tipo de relação de trabalho; e domínio (ou especialização) da competência que se relaciona às características do contexto do trabalho como área de conhecimento, função, atividade econômica, processo produtivo, equipamentos, bens produzidos que identificarão o tipo de profissão ou ocupação. Agrega os empregos por habilidades cognitivas comuns exigidas no exercício de um campo de trabalho mais elástico, composto por um conjunto de empregos 
similares que vai se constituir em um campo profissional de determinado domínio. Assim como a ocupação, o grupo de base ou família ocupacional é uma categoria sintética, um construto, ou seja, ela é elaborada a partir de informações reais, mas ela não existe objetivamente. A estrutura da CBO pressupõe somente um nível de competência possível por ocupação, família, subgrupo, subgrupo principal e grande grupo ocupacional, mas em alguns poucos casos não foi possível manter esse critério.

Os grandes grupos formam o nível mais agregado da classificação. Comportam dez conjuntos, agregados por nível de competência e similaridade nas atividades executadas. Por falta de outro indicador homogêneo entre países, a CIUO 88 usou como nível de competência a escolaridade. A filosofia da CIUO 88 é de uma classificação de ocupações que coloca em segundo plano o critério de atividade econômica. O Quadro 1 sintetiza a estrutura geral da CBO.

Assim sendo, foram criados dez grandes grupos - GGs para a CBO. O GG 1 agrupa os empregos que compõem as profissões que estabelecem as regras e as normas de funcionamento para o país, estado e município, organismos governamentais de interesse público e de empresas, além de reunir os empregos da diplomacia. O GG 2 agrega os empregos que compõem as profissões científicas e das artes de nível superior. O GG 3 agrega os empregos que compõem as profissões técnicas de nível médio. O GG 4 agrega os empregos dos serviços administrativos, exceto os técnicos e o pessoal de nível superior. Trata-se de empregos cujos titulares tratam informações (em papéis ou digitalizadas, numéricas ou em textos). O GG 4 está subdividido em dois SGP - aqueles que trabalham em rotinas e procedimentos administrativos internos e aqueles que atendem ao público (trabalham com o público, tratam informações registradas em papéis ou formas magnéticas, operam equipamentos de apoio ao trabalho etc.). O GG 5 agrega os empregos que produzem serviços pessoais e à coletividade, bem como aqueles que trabalham na intermediação de vendas de bens e serviços. $\mathrm{O}$ GG 6 agrega os empregos do setor agropecuário. Na estrutura da $\mathrm{CBO}$, não foi adotado o conceito de "artesanal" da CIUO 88. Primeiramente porque é difícil, em um sistema de trabalho desestabilizado, fixar quais são as profissões "artesanais" no sentido de conhecer todo o processo e quais são as "profissões" parceladas. Sendo assim, reservaram-se os GG 7, 8 e 9 aos trabalhadores que fabricam bens, operam e mantêm equipamentos, sejam eles estacionários ou móveis (por 
exemplo, veículos). No GG 7 foram agrupados os trabalhadores de sistemas de produção que tendem a ser discretos e que lidam mais com a forma do produto do que com o seu conteúdo físico-químico. No GG 8 agruparam-se os trabalhadores de sistemas de produção que são ou tendem a ser contínuos (química, siderurgia, dentre outros). E, finalmente, no GG 9 foram classificados os trabalhadores de manutenção e reparação.

\section{QUADRO 1 - Estrutura dos Grandes Grupos da CBO}

\begin{tabular}{|c|l|c|}
\hline Código & \multicolumn{1}{|c|}{ Categorias } & Competências \\
\hline GG 0 & $\begin{array}{l}\text { Forças Armadas } \\
\text { Policiais } \\
\text { Bombeiros Militares }\end{array}$ & Não definido \\
\hline GG 1 & $\begin{array}{l}\text { Membros superiores do poder público } \\
\text { Dirigentes de organizações de interesse público } \\
\text { Dirigentes de empresas } \\
\text { Gerentes }\end{array}$ & Não definido \\
\hline GG 2 & Profissionais das ciências e das artes & 4 \\
\hline GG 3 & Técnicos de nivel médio & 3 \\
\hline GG 4 & Trabalhadores de serviços administrativos & 2 \\
\hline GG 5 & $\begin{array}{l}\text { Trabalhadores dos serviços } \\
\text { Vendedores do comércio em lojas e mercados }\end{array}$ & 2 \\
\hline GG 6 & $\begin{array}{l}\text { Trabalhadores agropecuários } \\
\text { Trabalhadores florestais }\end{array}$ & 2 \\
\hline GG 7 & Trabalhadores da caça e pesca & 2 \\
\hline GG 8 & Trabalhadores da produção de bens e serviços industriais & 2 \\
\hline GG 9 & Trabalhadores de manutenção e reparação & 2 \\
\hline
\end{tabular}

Os grandes grupos foram subdivididos em subgrupos principais, subgrupos e grupos de base. O subgrupo principal foi criado para: melhorar o equilíbrio hierárquico entre o número de grandes grupos e subgrupos e aprimorar as agregações por domínio. O subgrupo indica, de forma ampla, o domínio dos campos profissionais de famílias ocupacionais agregadas. E, o grupo de base ou família ocupacional agrupa situações de emprego ou ocupações similares. É possível verificar que o Brasil, com a $\mathrm{CBO}$, acompanha as ideias que fundamentam a divisão do trabalho internacional embasadas, também, pelo CIUO.

Cabe apresentar a forma de proteção à saúde e segurança do trabalho na versão brasileira. O mundo do trabalho é fonte de lesões, adoecimento e morte desde priscas eras, segundo apresenta Santos (2012). O autor cita exemplos desse fenômeno com base em documentos antigos, inclusive no Novo Testamento de Lucas, em que está registrada a queda da Torre de Siloé que resultou na morte de 
trabalhadores. Também aponta a intoxicação por chumbo de um trabalhador de minas, informada por Hipócrates em seus escritos. O fenômeno, portanto, é de longa data, considerando os casos registrados. Na sequência das ideias, Santos (2012) mostra que durante a Revolução Industrial houve considerável aumento do número de agravos à saúde e segurança no trabalho. Com esse advento surgem as primeiras ações no âmbito da prevenção. Inicialmente na Inglaterra, o primeiro programa que se tem notícia surge com a Lei de saúde e moral dos aprendizes, em 1802. Esse cuidado se desenvolve internacionalmente no pós-segunda Guerra Mundial com a criação da Organização Internacional do Trabalho - OIT, em 1919.

No Brasil, esta situação foi por muito tempo deixada de lado. Segundo Santos (2012)

Durante o período colonial e imperial (1500-1889), a maior parte do trabalho braçal era realizada por escravos (índios e negros) e homens livres pobres. A preocupação com suas condições de segurança e saúde no trabalho era pequena e essencialmente privada. $\mathrm{O}$ desenvolvimento de uma legislação de proteção aos trabalhadores surgiu com o processo de industrialização durante a República Velha (1889-1930). Inicialmente esparsa, a legislação trabalhista foi ampliada no Governo Vargas (1930-1945) com a Consolidação das Leis Trabalhistas - CLT em 1943 (SANTOS, 2012, p.23)

Embora a saúde e segurança no trabalho constituam uma área com participação interministerial, envolvendo o Ministério da Saúde-MS e o Ministério da Previdência Social-MPS, o Ministério do Trabalho e Emprego-MTE tem a responsabilidade de intermediar a subordinação jurídica entre o trabalhador e o tomador de seu serviço. As atribuições do MTE são: política e diretrizes para a geração de emprego e renda e de apoio ao trabalhador; política e diretrizes para a modernização das relações de trabalho; fiscalização do trabalho, inclusive do trabalho portuário, bem como aplicação das sanções previstas em normas legais ou coletivas; política salarial; formação e desenvolvimento profissional; segurança e saúde no trabalho; política de imigração; e, cooperativismo e associativismo urbanos. No que se refere a segurança e saúde do trabalhador, o MTE tem as atribuições de regulamentar; atualizar as normas; e, inspecionar os ambientes laborais.

O referencial normativo em Saúde e Segurança no Trabalho-SST do MTE foi inspirada na Carta del Lavoro italiana de 1927 e, embora muito do conjunto de normas deste documento permaneçam em vigência, desde 1977 as influências 
para a atualização de normas são oriundas das convenções da OIT. Das 188 convenções da OIT, o MTE ratificou e estão em vigor 82, das quais 20 tratam especificamente da SST. Entre elas estão duas de amplo espectro, as convenções 148 e 155.

A convenção 148, de 1977, trata dos riscos ocupacionais no ambiente de trabalho oriundos da poluição do ar, ruído e vibração e foi adotada pelo TEM em 1982. Três aspectos são relevantes nesse tema: privilégio de medidas de proteção coletivas; consulta a representantes de trabalhadores e empregadores no estabelecimento de parâmetros de proteção; e, obrigatoriedade de controle médico sem ônus para o trabalhador.

Na convenção 155, de 1981 e promulgada no Brasil em 1994, o viés foi a instituição de política nacional de segurança e saúde dos trabalhadores e do meio ambiente de trabalho, com base no conceito atual de ergonomia e participação de trabalhadores e empregadores de forma representada.

A SST se utiliza de normas regulamentadoras, as NRs, definidas para a proteção e fiscalização do trabalhador e orientação de empregadores. São elas: NR-1 Disposições gerais; NR-2 Inspeção prévia; NR-3 Embargo ou interdição; NR-4 Serviços especializados em engenharia de segurança e em medicina do trabalho - SESMT; NR-5 Comissão interna de proteção individual - CIPA; NR-6 Equipamento de proteção individual - EPI; NR-7 Programa de controle médico de saúde ocupacional - PCMSO; NR-8 Edificações; NR-9 Programa de prevenção de riscos ambientais - PPRA; NR-10 Segurança em instalações e serviços em eletricidade; NR-11 Transporte, movimentação, armazenagem e manuseio de materiais; NR-12 Máquinas e equipamentos; NR-13 Caldeiras e vasos de pressão; NR-14 Fornos; NR-15 Atividades e operações insalubres; NR-16 Atividades e operações perigosas; NR-17 Ergonomia; NR-18 Condições e meio ambiente de trabalho na indústria de construção; NR-19 Explosivos; NR-20 Líquidos combustíveis e inflamáveis; NR-21 trabalho a céu aberto; e de conforto nos locais de trabalho;NR-22 Segurança e saúde ocupacional na mineração; NR-23 Proteção contra incêndios; NR-24 Condições sanitárias; NR-25 Resíduos industriais; NR26 Sinalização de segurança; NR-27 Registro profissional do técnico de segurança do trabalho no Ministério do trabalho; e, NR-28 Fiscalização e penalidades. 
No que se refere ao quantitativo de trabalhadores sem proteção da SST do MTE, entre 2012 e 2017, o percentual de pessoas variou de 43,1\% a 46,2 \%. Com a interpretação da tabela 1, é possível constatar esse indicador.

Tabela 1 - Pessoas sem proteção do SST - MTE (2012-2017)

\begin{tabular}{|c|c|c|c|c|}
\hline Ano & $\begin{array}{c}\text { População em } \\
\text { idade de trabalhar }\end{array}$ & $\begin{array}{c}\text { População } \\
\text { ocupada }\end{array}$ & $\begin{array}{c}\text { População } \\
\text { desocupada }\end{array}$ & $\begin{array}{c}\text { Percentual } \\
\text { sem proteção }\end{array}$ \\
\hline 2012 & 157.267 & 89.497 & 67.771 & 43,1 \\
\hline 2013 & 159.511 & 90.764 & 68.747 & 43,1 \\
\hline 2014 & 162.029 & 92.112 & 69.917 & 43,2 \\
\hline 2015 & 164.344 & 92.142 & 72.202 & 43,9 \\
\hline 2016 & 166.371 & 90.384 & 75.988 & 45,7 \\
\hline 2017 & 168.362 & 90.647 & 77.715 & 46,2 \\
\hline
\end{tabular}

Fonte: IBGE/PNAD julho2018 (adaptado)

Essa proteção será ampliada se a sanção presidencial do Plano Nacional de Segurança e Saúde no Trabalho, proposta em 2010, for realizada. Até 2018 isto não ocorreu. Este plano comporta as seguintes diretrizes: inclusão dos trabalhadores brasileiros no sistema nacional de promoção e proteção da saúde; harmonização da legislação e a articulação das ações de promoção, proteção, prevenção, assistência, reabilitação e reparação da saúde do trabalhador; adoção de medidas especiais para atividades laborais de alto risco; estruturação de rede integrada de informações em saúde do trabalhador; promoção da implantação de sistemas e programas de gestão da segurança e saúde nos locais de trabalho; reestruturação da formação em saúde do trabalhador e em segurança no trabalho e estímulo à capacitação e à educação continuada de trabalhadores; e, promoção de agenda integrada de estudos e pesquisas em segurança e saúde no trabalho.

No mesmo plano constam as responsabilidades do MTE na implantação: formular e propor as diretrizes da inspeção do trabalho; supervisionar e coordenar a execução das atividades relacionadas a SST; elaborar e revisar, em modelo tripartite, as NRs; promover estudos da legislação trabalhista e correlata, no âmbito de sua competência, propondo o seu aperfeiçoamento; e, acompanhar o cumprimento, em âmbito nacional, dos acordos e convenções ratificados pelo governo brasileiro junto a organismos internacionais, em especial à OIT. 
Embora deva ser reconhecido o avanço dessa proteção ao trabalho humano da forma como vem sendo aplicada, é curioso constatar que, para a SST sob a égide do MTE, os corpos sofridos pelo trabalho não estão c'alma...

\subsection{Mundo do trabalho em tempos sombrios}

Exclamando que intelectuais são capazes de agir sobre assuntos humanos de forma inteligente, Chomsky (2017) relata que,

Dewey levou apenas alguns anos para passar de responsável intelectual da Primeira Guerra Mundial a anarquista dos palanques de aulas e palestras, denunciando a imprensa não livre e questionando até que ponto a genuína liberdade intelectual e responsabilidade social são possíveis em qualquer grande escala sob o regime econômico existente (p.15).

Diferente de outros intelectuais, Dewey teve a sorte de poder, pelo menos, clamar. No mundo, e o Brasil não foi exceção, embora em épocas diversas, os tempos sombrios fizeram muitos calar, senão por capacidade de argumentos, pela força. Chomsky (1991) relembra o calvário de Bertrand Russell, Eugene Debs, Rosa de Luxemburgo, Karl Liebknecht, Zola, Thorstein Veblen, Randolph Bourne, Nelson Mandela, e muitos outros não nomeados individualmente, mas, da mesma forma, mencionados coletivamente.

Sobre o fenômeno no Brasil, Chomsky (2017) afirma que "Uma iniciativa de grande envergadura foi um golpe militar no Brasil, respaldado por Washington e implementado pouco depois do assassinato de Kennedy, que instituiu um homicida e brutal Estado de Segurança Nacional" (p.21).

Foi isso. Em 2012, numa sessão da Comissão da verdade com advogados de presos e perseguidos políticos do Brasil, a advogada Eny Moreira fez um relato emocionado sobre os ferimentos que ela constatou no corpo morto de Aurora Maria Nascimento Furtado, que foi entregue por agentes no Caju, em 11/11/1972. $\mathrm{Na}$ noite anterior o apresentador Cid Moreira, no telejornal da Globo, havia informado que a terrorista Aurora teria morrido em decorrência de ferimentos ocorridos, num tiroteio com as forças de segurança. Entretanto, não foram ferimentos decorrentes de tiroteio que a advogada constatou ao fazer o reconhecimento. O corpo da estudante de Psicologia na Universidade de São 
Paulo, segundo o relato de Eny Moreira, tinha $\operatorname{marcos}^{2}$ da ação truculenta da tortura do regime. Segundo ela, um olho de Aurora estava pulado para fora e o outro completamente preto; o cotovelo do lado esquerdo tinha um osso para fora; o maxilar estava afundado; não tinha bico do seio e também não tinha as unhas; havia inúmeras mordidas pelo corpo; no perímetro cefálico havia um afundamento pela ação de torniquete, denominado por coroa de cristo o que explicou o olho pulado.

Aurora Maria Nascimento Furtado, de 26 anos, na universidade, era responsável pela imprensa da UEE/SP e manteve ativa presença no movimento estudantil nos anos 1967 e 1968, como militante da Aliança Libertadora NacionalALN. Nos registros oficiais da Comissão da Verdade do Estado de São Paulo consta que:

Foi presa em 9 de novembro de 1972, no bairro de Parada de Lucas, Rio de Janeiro, durante uma batida policial realizada por uma patrulha do $2^{\circ}$ Setor de Vigilância Norte, após rápido tiroteio, em que matou um policial. Depois de correr alguns metros e esconder-se em vários lugares, Aurora foi aprisionada, viva, dentro de um ônibus onde havia se refugiado. Foi torturada desde o momento de sua prisão na presença de vários populares que se aglomeravam ao redor da cena. Aurora foi conduzida para a Invernada de Olaria, onde continuou sendo torturada por policiais do DOI-CODI/RJ e integrantes do Esquadrão da Morte. Aurora viveu os mais terríveis tormentos nas mãos dos torturadores que, além de utilizarem os tradicionais paus-de-arara, sessões de choques elétricos, espancamentos, afogamentos e queimaduras, aplicaram-lhe a "coroa de Cristo", ou torniquete, uma fita de aço que vai sendo gradativamente apertada, esmagando aos poucos o crânio da vítima. Em 10 de novembro, morreu em consequência das torturas, quando jogaram seu corpo crivado de balas na esquina das ruas Adriano com Magalhães Couto, no bairro do Méier, no Rio de Janeiro. Seu corpo chegou ao IML/RJ classificado como o de "desconhecida", pela guia 43 da $26^{\mathrm{a}}$ DP. A versão oficial divulgada pelos órgãos de segurança, publicada no jornal $O$ Estado de S. Paulo, de 11 de novembro de 1972, afirmava: Na madrugada de ontem, Aurora Maria Nascimento Furtado, que fora presa às 9h40min de 9 de novembro, conduzia agentes da polícia carioca a um local do Méier, na Guanabara, onde estaria localizado um "aparelho" (local de encontro) da organização terrorista Aliança Libertadora Nacional, informa o documento distribuído ontem pelas autoridades de segurança da Guanabara. Chegando à esquina da rua Magalhães Couto e Adriano, Aurora pediu para descer. Disse que preferia, por motivos de segurança, dirigir-se sozinha, a pé, até o "aparelho", próximo dali. Ao descer, Aurora saiu correndo e gritando em direção a um Volkswagen que estava nas proximidades. Nesse momento, começou um intenso tiroteio entre os agentes da polícia e os ocupantes do carro. Ao terminar o tiroteio, Aurora, baleada, estava morrendo, caída na rua. Preocupados em socorrer Aurora Maria, os agentes procuraram atendê-la. Com isso não alcançaram o grupo do Volkswagen, que arrancou em alta velocidade. A necropsia feita no IML em 10 de novembro, firmada pelos legistas Elias Freitas e Salim Raphael Balassiano, confirma a falsa versão policial

\footnotetext{
${ }^{2}$ No discurso da advogada o termo foi "marcas", a alteração para marcos foi propositalmente grifada.
} 
de morte em tiroteio e assinala como a causa mortis "[...] ferimentos penetrantes na cabeça com dilaceração cerebral". Descreve ainda 29 perfurações por projétil de arma de fogo, não especificando, entretanto, as entradas e saídas dos tiros, não permitindo a reconstituição das trajetórias. Foram encontrados oito projéteis em seu corpo. Os projéteis usados eram de vários calibres, pois as perfurações variaram de 5 a 19 milímetros, com pontas de metal amarelo ou chumbo nu. O laudo afirma que o tórax e o abdômen foram transfixados por projéteis, mas " [...] as cavidades pleurais não contêm sangue; a cavidade abdominal não contém sangue; na região glútea direita há três orifícios sem reação vital". Ou seja, os tiros, pelo menos parte deles, foram dados quando Aurora já estava morta, apenas para confirmar o tiroteio que não ocorreu e que é assumido como verdadeiro pelos legistas. As lesões no crânio são descritas como feridas irregulares de 60 e 25 milímetros, localizadas nos parietais esquerdos e direito. Essas medidas não são de projéteis, o que confirma a denúncia de que Aurora foi morta sob tortura com a coroa de Cristo.

Assim como há heróis para os grandes feitos para o bem comum, há também, nomeados, os algozes na ordem inversa. E a Comissão da Verdade, com o compromisso da transparência, disponibiliza publicamente os registros que informam os responsáveis pelo mal feito (Quadro 2). Cabe a lembrança dos conceitos de cínicos viris e antolhos voluntários proposto por Dejours (2005). Cínico viril refere-se àqueles que, dotados de poder de decisão, agem em nome da autoridade à qual estão subordinados, para garantir o mal feito. Antolhos voluntários, de outro lado, são todos os que, sem poder de decisão, percebem o mal feito, mas são impotentes na luta pelo bem comum.

\section{QUADRO 2 - Identificação de responsáveis - caso Aurora}

\begin{tabular}{|c|c|c|c|c|c|}
\hline Órgão / Período & Nome & Função & conduta & $\begin{array}{l}\text { Vivo/date } \\
\text { do óbito }\end{array}$ & Observaçöes \\
\hline IML- RJ & Elias Freitas & $\begin{array}{l}\text { Médico } \\
\text { legista }\end{array}$ & $\begin{array}{l}\text { Falsificação } \\
\text { de laudo } \\
\text { necroscópico }\end{array}$ & & Dossiê, p. 388 \\
\hline IML - RJ & $\begin{array}{l}\text { Salim Raphael } \\
\text { Balassiano }\end{array}$ & $\begin{array}{l}\text { Médico } \\
\text { legista }\end{array}$ & $\begin{array}{l}\text { Falsificação } \\
\text { do laudo } \\
\text { necroscópico }\end{array}$ & & Dossiê, p. 388 \\
\hline $\begin{array}{l}\text { DOl-Codi do I } \\
\text { Exército - RJ }\end{array}$ & $\begin{array}{l}\text { Adyr Fiúza de } \\
\text { Castro }\end{array}$ & Comanc & $\begin{array}{l}\text { Prisão, } \\
\text { tortura e } \\
\text { assassinato }\end{array}$ & morto & Dossiê, p. 388 \\
\hline
\end{tabular}

Fonte: Comissão da verdade do Estado de São Paulo.

http://comissaodaverdade.al.sp.gov.br/mortos-desaparecidos/aurora-maria-nascimento-furtado

Essa foi a realidade brasileira nos idos entre 1961 e as "Diretas já". Há um corolário de casos de desaparecidos e mortos, considerados pelo regime como 
terroristas, ou no dizer de Chomsky (2017), prophets, que foram acusados de corromper almas da sociedade de forma geral. E, sendo assim "Eles enfureceram violentamente o establishment com suas críticas análises geopolíticas, suas condenações dos crimes dos poderosos, suas reivindicações de justiça e sua preocupação com os pobres sofridos”. (CHOMSKY, 2017, p. 31). Conclamar os intelectuais quanto à responsabilidade na medida em que são privilegiados é a ação de Chomsky (2017), porque privilégio remete à responsabilidade e neste lugar há escolhas. Sim, há escolhas na vita activa (ARENDT, 1991), sobretudo em relação ao binômio ação/pluralidade como atividade política.

Hobsbawm (1998) apresenta uma importante análise do fenômeno denominado terceiro mundo. No seu estudo o autor mostra que um dos fatores coincidentes nos países incluídos como terceiro mundistas foi, justamente, a predominância de regimes militares.

Se omitirmos o corpo principal dos regimes comunistas do Terceiro Mundo (Coréia do Norte, China, as repúblicas indochinesas e Cuba), e o regime há muito estabelecido oriundo da Revolução Mexicana, é difícil pensar em quaisquer repúblicas que não tenham conhecido pelo menos episódicos regimes militares depois de 1945 (p.340).

A tônica do texto de Hobsbawm (1998), sobretudo, remete à explosão demográfica mundial, principalmente, dos países pobres.

A explosão demográfica no mundo pobre foi tão sensacional porque as taxas de nascimento básicas nestes países foram em geral muito mais altas que a dos períodos históricos correspondentes nos países desenvolvidos, e porque a enorme taxa de mortalidade, que antes continha a população, caiu como uma pedra a partir da década de 1940 - quatro ou cinco vezes mais rápido que a queda correspondente na Europa do século XIX (p. 338).

Interessante fazer um parêntese sobre as estratégias pensadas pelos mestres da humanidade que "eram de longe os principais arquitetos da política e iam ao encalço de sua vil máxima: tudo para nós e nada para os outros" (CHOMSKY, 2017, p. 17). E aqui se bebe na fonte da análise do Informe Lugano (GEORGE, 2013), em que a autora, misturando fatos e acontecimentos da realidade, propõe inferências permeadas com os escritos de vários pensadores contemporâneos. Assim a história é relatada.

Um organismo llamado Grupo de Solicitantes, cuya sede se encuentra em la cidad suiza de Lugano (no muy lejos de Davos), les encomenda a unos intelectuales la tarea de reflexionar sobre como podría ser esta política estratégica mundial. El trabajo de este cenáculo de pensadores esta sintetizado en el Informe Lugano I (...). Se enumeraron entonces três grandes retos: el médio ambiente, la gestión de 
la sociedade y las finanzas. Hoy, el mesmo Grupo de Solicitantes reclama um segundo informe que haga al mismo tempo um balance de las medidas adoptadas y de los nuevos retos, siempre según la misma preocupación: cumplir los objetivos de la globalización liberal y garantir la eternidade del capitalismo financeiro mundia. (GEORGE, 2013, prólogo, p. 14).

Inicia-se pelo Lugano I (2010) que trata, especificamente, sobre a situação do planeta no ponto de vista demográfico e ecológico na década de 1990. A ideia era diminuir a pressão demográfica de qualquer forma, coercitivamente ou não. Entre os temas apontados estão fome, epidemias e guerras. Sim, isso mesmo, fome, epidemias e guerras! E o argumento básico é a simples existência de muitas pessoas que não estão incluídas na população economicamente ativa-PEA, consideradas inúteis porque não produzem e tampouco consomem o suficiente, mas que ocupam espaço, físico, social e ecológico, no planeta.

Segundo a autora, tanto as mudanças climáticas quanto o desmembramento social atentam para o perigo iminente.

¿Pueden el médio ambiente y la sociedade civilizada sostener las cifras actuales y futuras? ¿Debe ser representada la cultura occidental por el 15\%, despúes por el $10 \%$ y después por el 5\% de la humanidade? ¿Deben sacrificar su bienestar los indivíduos y las naciones más productivos em aras de unos dudosos benefícios para los menos productivos? ¿Deben renunciar a su autoridade los países que ahora son poderosos? Éstas son las preguntas que nuestro análisis nos obliga a plantearmos a nosotros mismos y a los Solicitantes; por nuestra parte, la respuesta es "no" a todas ellas (GEORGE, 2013, p. 233).

Uma das conclusões para esta negativa é a de que o mercado mundial jamais incluirá todas as pessoas, inclusive o potencial grupo em idade produtiva. A informação de dirigentes governamentais de que priorizam a criação de empregos é irreal na análise da autora. ${ }^{3}$

Vale aqui mostrar os indicadores de tendência brasileira. O IBGE disponibiliza uma plataforma em que é possível verificar vários indicadores relacionados à economia, geociências e população. Pelo acesso interativo à pirâmide etária verifica-se a tendência populacional. (Quadro 3). Assim, pesquisando as informações sobre pessoas em idade ativa, entre 1990 e 2030, verifica-se que o aumento rápido da competição potencial, cada vez mais acelerada, no mercado produtivo, vem ocorrendo nos demais países ditos do terceiro mundo, tal como citado, também, por George (2013).

\footnotetext{
${ }^{3}$ Vide o recente ato falho do presidente em exercício no Brasil, Michel Temer, em que ele comemora ter feito "voltar o desemprego"!
} 


\section{QUADRO 3 - Projeção da População ativa no Brasil}

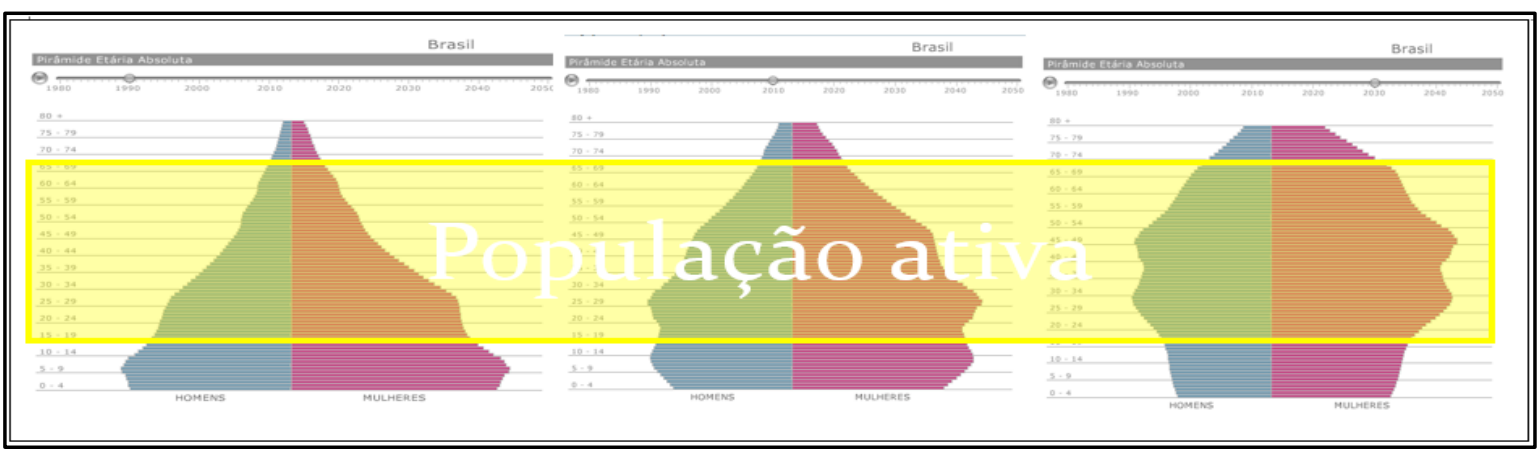

Fonte: IBGE - Projeção de População. (consulta)

http://www.ibge.gov.br/home/estatistica/populacao/projecao_da_populacao/2008/piramide/piramide.shtm

Concomitantemente, a partir de 2015, o cenário mostra uma forte ruptura na empregabilidade, como informa o Instituto Brasileiro de Geografia e EstatísticaIBGE, demonstrado pelo ADVFN Brasil: Portal de investimentos em ações da bolsa de valores do Brasil, que consubstancia os indicadores para os investidores BOVESPA e BM\&F. (Gráfico 1)

\section{GRÁFICO 1 - Taxa de desemprego no Brasil (2004-2016)}

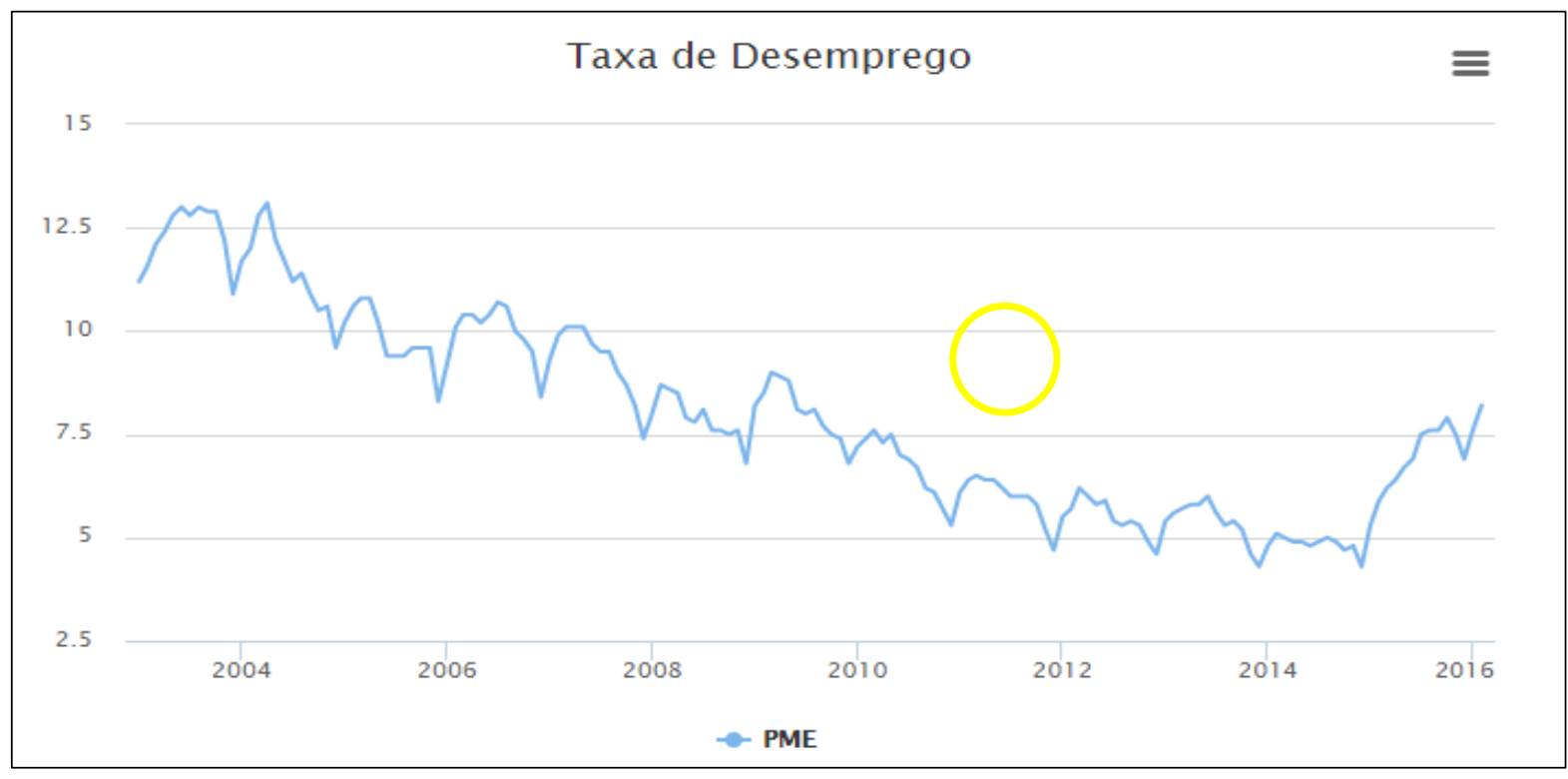

Fonte: ADVFN Brasil: Portal de investimentos em ações da bolsa de valores do Brasil, com cotações da Bovespa e BM\&F. https://br.advfn.com/indicadores/pme

No relato de George (2013), de modo semelhante ao Grupo de Solicitantes, foi criado um Grupo denominado Good Club, que inspirados nas análises de Bill 
Gates, chegaram a conclusão, também, que priorizar soluções para a superpopulação, considerada ameaçadora é ação fundamental. Este grupo, reunido na residência de Sir Paul Nurse, prêmio Nobel de Biologia, teria como participantes vários multimilionários, "segun The Sunday Times fueron David Rockefeller Jr., Warren Buffet, George Soros, Michael Bloomberg, Ted Turner e Oprah Winfrey George” (p.237). Da reunião resultou o comprometimento para investimentos filantrópicos em saúde e educação. A autora questiona sobre este meio de alcançar o proposto e analisa empreendimentos anteriores e seus fins para compreender o interesse deste grupo. E, acertadamente faz um estudo sobre a AGRA, programa implantado na África, também por Bill Gates, de forma aparentemente filantrópica. Vale dizer que o programa, associado à Monsanto, visou a produção de alimentos testando transgênicos sem comprovação científica sobre suas consequências e, sobretudo, conhecendo os riscos de transformação em inférteis os solos antes potenciais, que estavam sendo usados como sujeitos da pesquisa monsanteana.

O tema da filantropia, em tempo, tomou um rumo vultoso na mentalidade mundial. E por que não afirmar que, aparentemente virtuoso, pelo discurso explicitado, quando analisado pelo discurso pronunciado reservadamente, verifica-se que, na verdade é vantajoso, em seu discurso não dito. (SOARES, 2004) ${ }^{4}$. A fórmula $\mathrm{Vu}+\mathrm{Vi}=\mathrm{Va}$ da mentalidade filantrópica contemporânea, onde dado o caráter publicamente vultoso em virtuosidade resulta em vantagem. Este resultado beneficia a quem? Certamente aos beneméritos, que escolhem a quem, aonde, e o quanto em valores e tempo, desejam beneficiar por ação assistencialista. Se retirada, não produz mais os efeitos nos beneficiados, mas, desenvolvimentista para os fins dos próprios beneméritos, sim, porque em médio e, talvez, longo prazo, se beneficiarão, também, vultuosamente. Acrescente-se o caráter $a$-viltoso neste maniqueísmo.

\footnotetext{
${ }^{4}$ Soares (2004) mostra que a leitura atenta dos discursos organizacionais revela palavras sequer pronunciadas e de que existem contradições entre o que os membros das organizações assumem como sendo ética, moral e democracia e o que efetivamente é praticado no ambiente organizacional. Esta outra face da responsabilidade social corporativa é desvelada ao identificar-se os três tipos de discurso: o explicitado, o pronunciado reservadamente e o não-dito. Uma análise crítica do discurso não-dito revela o que se esconde por trás das ações preconizadas pela responsabilidade social corporativa bem como as contradições inerentes a essas práticas.
} 
No Brasil o Instituto Nacional de Metrologia, Qualidade e TecnologiaINMETRO é o órgão formal em relação à certificação sobre responsabilidade social.

A palavra Responsabilidade é originária do latim Responsus (...) e o termo Social está relacionado à sociedade, à característica de interação dos organismos vivos, de sua coexistência coletiva, independentemente de serem ou estarem conscientes dessa interação ou da interação ser voluntária ou involuntária. Aplica-se a populações tanto de seres humanos quanto de outras formas de vida. (...) refere-se àqueles a quem nossas atitudes, escolhas e decisões, de algum modo, geram consequências, impactam ou afetam. (...). Portanto, a responsabilidade social está intrinsecamente relacionada aos indivíduos, à responsabilidade perante os outros a quem, direta ou indiretamente, consciente ou inconscientemente, estamos ligados e para quem nossas escolhas, decisões e ações possam causar impactos. A partir dos anos 1990, surgiu uma nova visão sobre a Responsabilidade Social: a que se materializa por meio de políticas, estratégias e ações que visam, em última instância, a contribuir para o Desenvolvimento Sustentável (DS). E, para que o desenvolvimento seja sustentável, passa a ser necessária uma revisão de crenças e valores que embasam as ações sociais de todas as organizações, bem como o desenvolvimento de novos modelos de atuação dos diferentes atores sociais. Em 2010, a International Organization for Standardization - ISO, entidade que coordena a elaboração de normas técnicas Internacionais de diversos assuntos, publicou a ISO 26000 - Diretrizes sobre Responsabilidade Social (p. 7-9).

Essa norma, ISO 26000 e, também, a NBR 16001 são a base para certificação das organizações públicas e/ou privadas no Brasil com o selo de responsabilidade social. Cabe colocar que as empresas certificadas utilizam o selo em seus discursos explicitados, sobretudo em peças de publicidade.

Como exemplo da análise sugerida por Soares (2004), é possível descrever o caso da empresa AngloGold Ashanti do Brasil (RICHARDSON. e outros, 2017). No discurso explicitado verifica-se que o projeto de responsabilidade social denominado Raposos Sustentável, foi criado sob a égide da Ashanti que explora minério de ouro no Quadrilátero Ferrífero situado no Estado de Minas Gerais. Com tecnologia avançada na atividade de mineração em subsolo, no texto publicado, a Ashanti afirma que promove saúde e segurança dos trabalhadores como primeiro compromisso da empresa. Da mesma forma, cita que seu desempenho operacional está relacionado à habilidade de construir e fortalecer relações com a sociedade e em ser reconhecida como parceira de seu público. A melhoria da qualidade de vida das comunidades vizinhas aos seus empreendimentos é referida como compromisso essencial. A aplicação prática deste compromisso, é análoga aos propósitos do Good Club, citado por George (2013). A Ashanti o faz por meio do incentivo fiscal investido em educação, 
geração de renda, saúde e qualidade ambiental, além de esporte e cultura. O projeto Raposos Sustentável, financiado pela Ashanti foi executado pela ONG Centro Popular de Cultura e Desenvolvimento-CPCD, que foi fundado na comunidade de Raposos em parceria com a própria Ashanti. O projeto da CPCD, criou o Banco da Solidariedade, entidade que não é financeira, como pode parecer, mas uma locadora de projetos de ensino para a comunidade tendo como docentes os próprios membros da comunidade de forma voluntária que, para além das aulas, também gerenciam os recursos necessários. Como fonte de informação para análise do discurso pronunciado reservadamente, Richardson. e outros (2017) se basearam em três reportagens: Raposos: da riqueza do ouro à estagnação de cidade-dorrmitório, publicada sob autoria de Bruno Porto, publicada no jornal online Hoje em dia; Doença respiratória atinge cerca de 500 mil trabalhadores da mineração, de autoria de Mário Zota, no Especial para Brasil de fato, de Minas Gerais; e, Ouro e arsênio na sentinela de Raposos, de autoria do sociólogo Tádzio Peters Coelho, publicada no site Guayabera Mineira: Mineração, Petróleo e Dependência. Na primeira reportagem a informação é a de que, ao fechar suas operações, os três mil empregados, sem emprego em Raposos, região dependente da mineração, buscaram trabalho em Belo Horizonte e entorno, e Raposos em crise econômica e social, passou a servir apenas como cidade dormitório. Na segunda matéria, sobre doenças respiratórias, a tônica é a possível falsificação de laudos de exames periódicos ocupacionais, que não informaram as doenças por inalação de partículas de dióxido de silício e poeiras minerais em 3077 trabalhadores da Ashanti. Na terceira fonte, a informação é a de que em Galo Velho, local onde era realizada a separação entre ouro e rejeito que fica entre Raposos e Nova Lima, há um alto índice de contaminação por arsênio na população. Cerca de $85 \%$ dos operários examinados apresentaram lesões oriundas do arsenismo. Para além destes operários, a população de forma geral ficou exposta pela contaminação em índices acima do permitido na água consumida na região. Contrapondo-se os dois discursos anteriores, o explicitado e o pronunciado reservadamente, Richardson e outros (2017) apresentam, no discurso não dito, que entre os critérios para obtenção desta certificação estão a conformidade com a legislação aplicável e em consonância com normas internacionais além da real contribuição para o desenvolvimento sustentável. A Ashanti demonstra que não está preocupada com o impacto e consequências de 
longo prazo que suas operações resultaram e mesmo assim está certificada pela NBR 16001, conforme explicitado em seu site atualizado em 2017. Parafraseando Soares (2004), responsabilidade social corporativa: por uma boa causa?

Retomando Hobsbawm (1998), no seu estudo sobre a era dos extremos, cabe analisar a questão da Reforma Agrária e seus impactos no mundo do trabalho. Segundo o autor o pós Segunda Guerra Mundial, entre 1945 e 1950, houve ênfase neste fenômeno, na Europa Oriental, após 1949, na China, em 1952 no Egito, Iraque, Síria, Argélia e Cairo. Na América Latina, embora o fenômeno já se configurasse desde 1910, no México através de discussões políticas, efetivamente se iniciou em 1952 na Bolívia. No Brasil, a população aumentou de 51.941.767 em 1950 para 169.799.170 em 2000. E esse crescimento ocorreu de forma diferenciada por região. A região que apresentou o maior índice no período foi a sudeste, seguida pelo nordeste, sul, e centro-oeste e norte por último.

Entretanto, ao longo do período este crescimento foi diferenciado quando comparamos as regiões em cada década, em relação ao próprio crescimento. $\mathrm{O}$ nordeste teve o maior percentual de crescimento populacional entre 1950 e 1970, embora com tendência menor entre 1960 e 1970. Na década de 1980 e também na de 1990, o maior percentual de crescimento ocorreu na região sul. Na década de 2000, a região nordeste volta a ter o maior percentual de crescimento. (Gráfico 2).

Comparando-se o mesmo período entre 1950 e 2000 a população rural e urbana, verifica-se que houve uma inversão do fenômeno. A análise é realizada, também, de forma diferenciada por região. (Quadro 4). 
GRÁFICO 2 - Percentual de crescimento da população por região/década - (1950-2000)

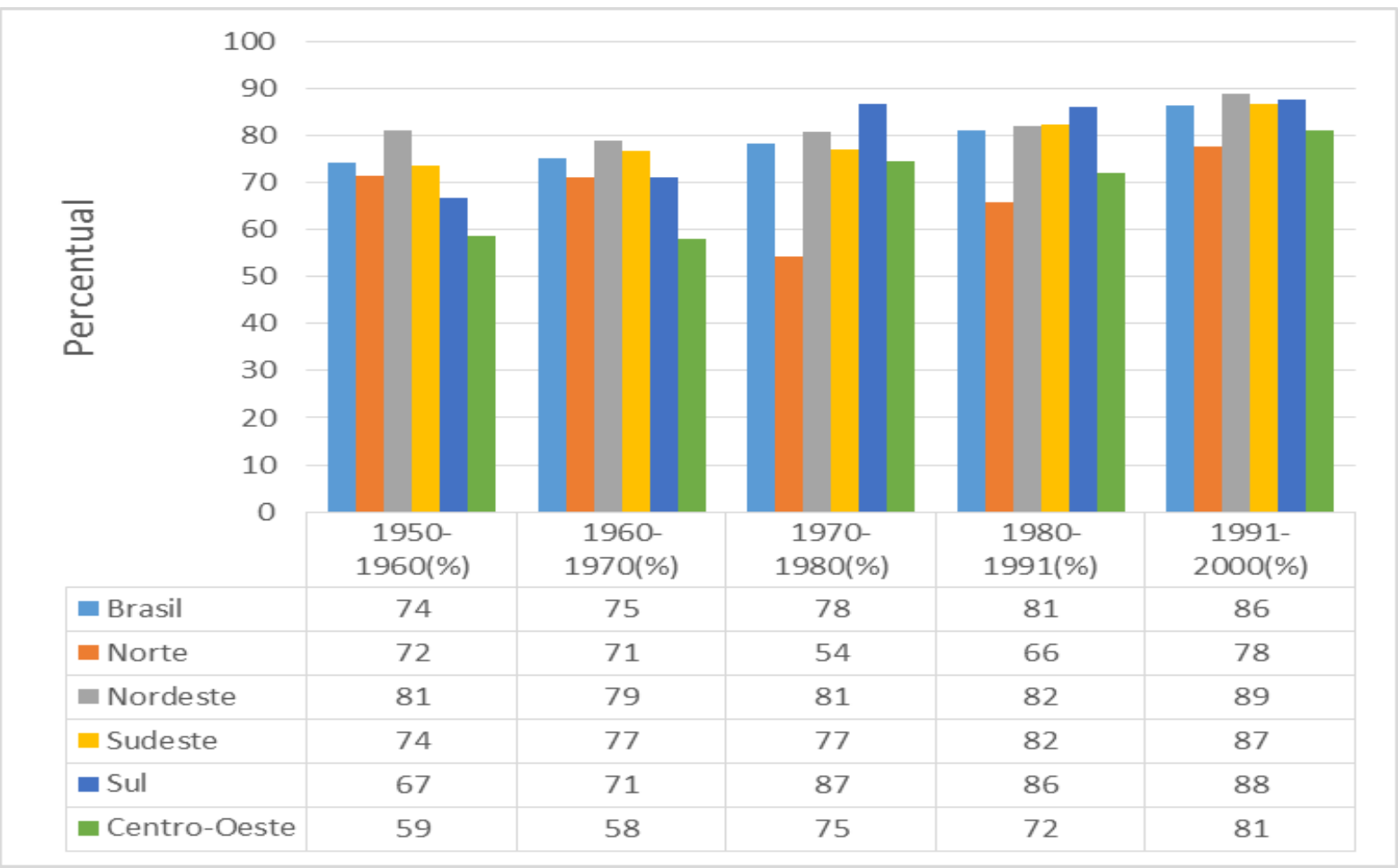

Fonte: IBGE (consulta)

\section{QUADRO 4 - Comparação entre população urbana e rural por região} $-(1950-2000)$

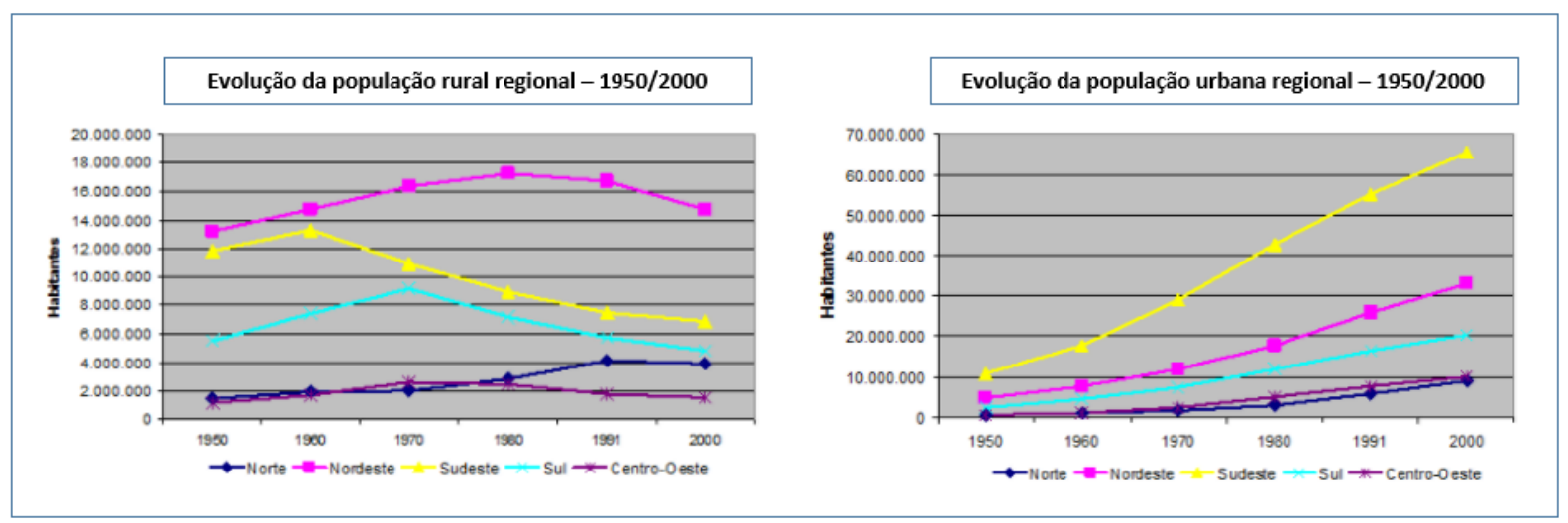

Fonte: IBGE (consulta)

Assim, é possível verificar que o fenômeno do êxodo rural está longe de se estabilizar. E essa concentração da população nas áreas urbanas traz 
consequências em vários fenômenos da geopolítica com impactos na vida cotidiana.

A transferência da população agrária para os centros urbanos potencializou uma nova divisão internacional de trabalho. Adicione-se a isto a transferência de industriais que produziam para o mercado mundial para outras partes do mundo. Segundo Hobsbawm (1998),

Isso se deveu em parte à deliberada mudança, por empresas do velho mundo industrial, de parte ou de toda a sua produção ou estoques para o Segundo e Terceiro Mundos, seguida eventualmente por algumas transferências até mesmo de processos bastante sofisticados em indústrias de alta tecnologia, como pesquisa e desenvolvimento. A revolução nos transportes e comunicações modernos tornou possível e econômica uma produção verdadeiramente mundial. Também se deveu aos esforços deliberados de governos do Terceiro Mundo para industrializarem-se, conquistando mercados de exportação, se necessário (mas preferentemente não) à custa da velha proteção de mercados internos. (p. 354).

O fenômeno não é particularidade do Brasil. As populações estão mais concentradas nas áreas urbanas de forma geral em todos os países. Dessa nova divisão do Trabalho originaram-se as classes operárias industriais nos países do terceiro mundo com a consequente luta por direitos trabalhistas e criação de sindicatos. Assim, ocorreu na Coréia do Sul, nos países da Europa Ocidental e, também, no Brasil, que originou, na década de 1980 o Partido dos Trabalhadores.

No estudo sobre o Informe Lugano II, George (2013) mostra que o sucesso dos movimentos sociais foi inquietante para os mestres da humanidade, porque novos prophets, desta vez organizados coletivamente, surgiriam com mais força para converter almas. Na visão da autora, inquietante também, mas porque os augúrios são o aparecimento de formas de arrogância e depreciação pelo sofrimento alheio. Ilustra isso com o acontecimento de possível ocupação em Wall Street em que,

banqueiros y operadores que estaban assomados al balcón por encima de los manifestantes se réian mientras bebían champán al más puro estilo de Maria Antonieta cuando dijo: "; Que coman pasteles !” (...) Las fotografias de policías llevando a cabo arrestos massivos o rociando gas pimienta contra manifestantes no violentos provocan reacciones de simpatia hacia las víctimas (p. 225).

Os solicitantes teriam que justificar aos mestres da humanidade que estes comportamentos são inapropriados. Essa ilustração parece tão factual quando analisamos a situação brasileira nos últimos anos. Um dos acontecimentos 
recentes, ocorrido em 2013é análogo a esta ilustração. Numa festa de casamento no Copacabana Palace houve uma manifestação social em que a tônica do protesto se referia aos serviços de transporte público no Rio de Janeiro. Por que uma manifestação desse tema na entrada do local de celebração de união? Porque a noiva é filha herdeira do empresário majoritário de concessão de transporte público e o noivo de deputado federal a época. A união dos filhos, simbolicamente representava a união entre políticos e empresários para obtenção de privilégios. Os manifestantes em protesto humorado e pacífico foram vigiados e contidos por um grande contingente de seguranças privados e públicos e atingidos moral e fisicamente por convidados. Do alto do primeiro andar do Copacabana Palace, os convidados lançavam dobraduras de aviõezinhos feitas com notas de $\mathrm{R} \$ 20,00$, em alusão hierárquica. Um dos manifestantes foi ferido por um cinzeiro jogado por um dos convidados.

Muitas manifestações sociais de protesto vêm ocorrendo nos últimos anos em que o tema sempre gira em torno do binômio política/capital. Citem-se as ocorridas na época dos grandes eventos Copa do Mundo e Olimpíadas e mais recentemente os gerados pela polarização patos e mortadelas em relação aos acontecimentos no poder executivo maior brasileiro. Nesse período surge o ativismo Black Bloc, visto pelo senso comum como marginais individuais e predadores. O movimento Black Boc não é um comportamento original surgido no Brasil. Remonta à década de 1970, na Alemanha, como uma nova estratégia anarquista.

Entre 1917 e 1920, o movimento anarquista esteve em pleno auge sob a égide de Edgard Leuenroth, jornalista criador de vários jornais de cunho em defesa do operariado brasileiro. Como introdutor do movimento anarquista neste país, participava de movimentos grevistas através da imprensa e na rua com discursos inflamados liderando protestos. O cerne do movimento era a propaganda e educação dos trabalhadores para a revolução. A greve geral de 1917 em São Paulo teve início tímido com a participação de 400 operários e operárias de uma indústria têxtil de São Paulo. O intuito da greve foi a atualização salarial e a abolição da extensão de carga horária noturna. Mas, na verdade, este início simbolizava o início do forte caráter de levante ligado "à reação contra a deterioração das condições de vida e de trabalho" (BIONDI, 2009, p. 3). Esta greve de inspiração anarquista se configurou como um ponto de divisão entre um 
período de desorganização das associações sindicais e a formação de grupos mais sólidos para estratégias defensivas coletivas.

Wallerstein (1998) apresenta quatro argumentos para explicar que a economia-mundo capitalista, sua geopolítica e sua geocultura estão num momento mais de mudança estrutural do que conjuntural: a desrruralização em ritmo acelerado no mundo; a deterioração ecológica; as pressões para democratizar o sistema mundo; e, por último o fim da polarização liberalismo/velha esquerda. Esta análise/previsão do autor parece estar sendo confirmada nestes tempos sombrios.

Quem manda no mundo do trabalho no mundo em tempos sombrios? Não se trata de identificar a nação ou um indivíduo com espírito ditatorial. Não, não se trata dos Estados Unidos, em declínio, ou de quaisquer outros candidatos à ascensão. Trata-se, sim, da doutrina dos programas neoliberais dos mestres da humanidade que pressiona a mão daqueles, pobres de espírito e moral, que seguram a caneta para assassinar o bem comum na vita activa. Para Chomsky (2017), “os programas neoliberais da geração passada concentraram riqueza e poder em um número bem menor de mãos ao mesmo tempo em que arruinaram a democracia vigente (...) os grandes partidos tradicionais rapidamente perderam integrantes à esquerda e à direita” (p. 298). Entretanto, há também, uma oposição crescente aos ataques neoliberais, e "essa desobediência preocupou as classes dominantes. "Atendo-nos apenas à história norte americana, George Washington considerava as pessoas comuns que formavam as milícias que ele comandava um povo excessivamente sujo e sórdido (...) uma espécie incompreensível de estupidez nas classes mais baixas dessa gente” (p. 299). Este pensador interpreta que esse desprezo pelas classes mais baixas dessa gente se apresenta por diversas formas. Mas, algumas poucas vezes, entretanto, os clamores contra o poder da doutrina neoliberal surtiram algum efeito neste período historicamente. $\mathrm{O}$ centro das atenções, no ponto de vista do autor, sobre quem manda no mundo contemporâneo, está sob a égide da Ásia Oriental, Europa e Oriente Médio. Isso se dá porque no conjunto destas regiões se encontra o maior alvo do poder bélico liderada pelos Estados Unidos. A conclusão do autor sobre quem manda no mundo é a de que mais do que nunca é preciso responder à pergunta: quais princípios e valores regem o mundo? Certamente não são aqueles de uma 
ideologia única. Mas da mentalidade, no tempo de longa duração, que se configura como substrato das diversas ideologias.

Como o exposto impacta diretamente a vita activa? Em oito de novembro, a Organização Meteorológica Mundial-OMM apresentou um relatório na COP-22 de 2016, a reunião anual da Conferência das Nações Unidas sobre mudanças climáticas realizada em Marrocos. O documento relatou que a elevação dos níveis dos mares derreterá mais rapidamente as calotas polares. Em decorrência, a população de Blangadesh, muito em breve, terão que migrar para outras terras ou viver em jangadas sobre águas salgadas, sem água potável para sobrevivência. $\mathrm{Na}$ Índia já há relatos sobre a existência de 300 milhões de pessoas sob a escassez de água. Relembre-se o Informe Lugano I: fome, epidemias e guerras.

E o que a atual potência mundial pensa e pratica sobre isso? O líder dessa potência, pelo viés do partido republicano, além de não se associar ao acordo de Paris da COP-2, efetiva o aumento do uso de combustíveis fósseis, além de extinguir o possível apoio aos países em desenvolvimento que estão buscando avançar no uso de energia sustentável. Essa é uma das mais fortes bandeiras embora incompreensível à análise do senso comum e do conhecimento científico - dos mestres da humanidade, que fomentam os programas neoliberais. Republicanos estão, com certeza, incluídos nesta visão. Mas o fato é que, embora pareçam estar na outra ponta da polarização ideológica, democratas, mais por omissão do que ação, também permitem a ascensão desta bandeira.

O que se perdeu na história da humanidade? Como pode ser explicada essa apatia e negativismo frente à catástrofe iminente? Que mistério se oculta para garantia da continuidade de vida no planeta? Surgirá um novo Messias, ou ressurgirá o Messias conhecido, que a todos salvará? Já existe vida possível em outro planeta? Há tecnologia criogênica para possível retorno de alguns poucos em tempos de possível reconstrução? Há meios de vida humana subaquática? É possível viver em forma hologramática? Há respostas para essas perguntas? Devem existir, mas que não estão acessíveis àqueles subordinados e subjugados aos mestres da humanidade. Mas isso é tema para desenvolver em outro tempo e em outro espaço.

De que forma esse sofrimento psíquico se articula com o mundo do trabalho? Relembrem-se as três atividades da vita activa (Arendt, 1991) e seus 
correlatos: labor/vida, trabalho/mundanidade e ação/pluralidade, com o entrelaçamento da política. Esse é o caminho da resposta que se percorre.

Chomsky (2017) relata, a título de posfácio do seu Quem manda do mundo, que, de modo análogo ao tema da catástrofe climática que se afigura, as ideologias republicana e democrata, tratam o trabalho humano com, senão sordidez, com a certeza da indiferença pelo sofrimento físico e psíquico a ele relacionado. Ilustra isso, com a análise do recente resultado do processo eleitoral estadunidense.

\footnotetext{
“(...) é importante reconhecer o veemente e fervoroso apoio que Trump recebeu dos raivosos e descontentes, notadamente eleitores brancos sem educação universitária, a classe operária e a classe média baixa. Houve inúmeros fatores, mas um deles é que esses grupos são vítimas das políticas neoliberais da geração passada, as diretrizes políticas descritas em detalhes por Alan Greenspan, presidente da Federal Reserve - FED, o banco central dos Estados Unidos-, em depoimento ao Congresso" (p.322).
}

Mais adiante descreve a política de economia liderada por Greenspan tendo como objetivo demonstrar que seu sucesso estava associado diretamente a insegurança para o trabalhador porque "trabalhadores intimidados não exigiriam aumento de salários nem benefícios, mas aceitariam de bom grado padrões de vida mais baixos em troca da mera possibilidade da manutenção do emprego" (p. $323)$.

Os resultados da aplicação desta política causaram insatisfação nos trabalhadores, e não sem razão. Para além de toda a penosidade imputada a eles, os salários em 2007, corrigidos pela inflação, estavam mais baixos que a remuneração em 1979, início da implantação da política econômica de Greenspan. Outro aspecto refere-se a instabilidade no mercado de trabalho em função da política de gestão de pessoas ter priorizado precarização do trabalho formal com a permissão de trabalhos temporários e terceirização.

Na conclusão de Chomsky (2017), o caminho para reencaminhamento da qualidade da vita activa está na mobilização popular e no ativismo. Pelo âmbito acadêmico, a construção de conhecimento sobre sofrimento psíquico relacionado ao trabalho, e sua aplicabilidade no mundo concreto do trabalho, com indicadores mensuráveis, é um caminho que, associado à vida cidadã, se configura como prática viável.

As conquistas trabalhistas obtidas desde a década de 1940 sofreram um golpe no que se refere aos direitos sociais e trabalhistas. Krein (2018) descreve as 
consequências da reforma trabalhista explicitadas pelo documento "Uma Ponte Para o Futuro" que serviu como base para a elaboração das estratégias neoliberais propostas pelo programa do PMDB para governar o Brasil nos últimos dois anos. Essas consequências implicam diretamente no âmbito das ações coletivas e, naturalmente diminuem a possibilidade do uso de estratégias de defesa coletiva por parte dos trabalhadores brasileiros.

As mudanças oriundas da reforma trabalhista estão consubstanciadas, principalmente em duas leis.: lei $\mathrm{n}^{\circ} 13.467 / 2017$ (alterações na CLT) e a lei $\mathrm{n}^{\mathrm{o}}$ 13.429/2017 (terceirização). O conjunto de mudanças apresenta duas consequências de amplo espectro que, certamente, potencializarão o sofrimento psíquico relacionado ao trabalho.

A primeira se refere à transferência das regras sobre relações de trabalho para as empresas, invocando a possibilidade de negociações entre patronato e empregados.

Nessa perspectiva, a reforma não se refere somente ao conteúdo da regulamentação, mas também às instituições públicas do trabalho que podem interferir tanto na aplicação quanto na materialidade dos direitos. Assim, por um lado, indica uma descentralização do processo de definição das regras da relação de emprego para o interior da empresa, inclusive de individualização da negociação para segmentos com melhor remuneração. (Krein, 2018, p.78)

A segunda está relacionada diretamente ao esvaziamento de sindicatos e suas convenções coletivas que:

tende a predominar uma organização mais descentralizada e articulada com os interesses da empresa. É a constituição de um padrão de regulação social mais afeita com as características do capitalismo contemporâneo, que proporcionou uma situação desfavorável aos trabalhadores. (Krein, 2018, p.78)

Segundo Krein, a negociação coletiva com base na regulação estatal compreende princípios básicos do direito do trabalho. De um lado está a relação entre capital e trabalho em que a existência de sindicatos, de forma efetiva, como essencial para assegurar a proteção do trabalhador que se caracteriza como a parte mais frágil da relação no que tange ao poder de decisões e de suporte técnico para a argumentação na negociação. De outro está a visão, defendida na justiça trabalhista de que o trabalho não deva ser caracterizado como mercadoria em função da dignidade da pessoa estar garantida.

Cabe aqui registrar, por exemplo, dois casos, no Brasil, de processos recentes relacionados ao assédio moral, praticados por empresas conhecidas, em 
que, houve mediação da regulação estatal: Processo 1) Uma funcionária do Carrefour Comércio e Indústria Ltda. sofreu assédio moral relacionados aos seguintes mecanismos: discriminação racial, tratamento grosseiro e excesso de trabalho. Essa situação perdurou durante catorze anos e, em decorrência do assédio moral, ela acabou sendo vítima da síndrome de esgotamento profissional, ficando incapacitada por três anos. É possível verificar que estes mecanismos se enquadram em grupos de ações descritos por Guimarães e Rimoli (2006). São eles: manipulação da comunicação com a vítima (tratamento grosseiro; manipulação da reputação da vítima -discriminação racial e manipulação do trabalho da vítima -excesso de trabalho. (Tribunal Superior do Trabalho Processo:RR - 331-41.2011.5.10.0018). Na sequência do processo a indenização para a vítima foi pautada em três aspectos: proporcionalidade, esgotamento profissional e discriminação racial. A indenização por proporcionalidade foi embasada na ênfase ao caráter pedagógico para gerar o valor da condenação da empresa ré, em que o relator argumenta que a empresa adote medidas preventivas de proteção ao trabalhador, em especial a mulher, de ações abusivas dos superiores hierárquicos. Sobre o esgotamento profissional, reconhecida como síndrome de burnout, de cunho depressivo e estresse crônico resultantes de condições de trabalho física e psicológica desgastantes. Por fim, em relação à discriminação racial sofrida por ela também foi vetor para o distúrbio psicológico. O Carrefour Comércio e Indústria Ltda. foi condenado, pela Sexta Turma do Tribunal Superior do Trabalho, a pagar R\$ 100 mil. Caso 2) A Schincariol Logística e Distribuição Ltda. em Curitiba (PR) foi condenada a indenizar em R \$ 20 mil, por dano moral, um vendedor submetido a condutas abusivas na cobrança de metas, entre elas a prática reiterada de ofensas pelo superior que configurou assédio moral. (Tribunal Superior do Trabalho - Processo:RR - 6830089.2009.5.09.0012). Quando havia o descumprimento de metas, segundo a vítima, ele era punido com a exigência de fazer polichinelos, escrever à mão, 50 vezes, as rotinas básicas do vendedor, sentar com venda nos olhos para receber borrifadas de água e, também relata agressão física com galhos de árvore ao mesmo tempo em que foi obrigado a gritar cantos motivacionais. O superior imediato justificava as técnicas como demonstração para que superasse as dificuldades. A sentença, por decisão unânime, baseou-se no entendimento de que houve extrapolação dos 
limites da razoabilidade e na afronta a dignidade humana, caracterizando assédio moral.

No Brasil não há estudos quantitativos suficientes para avaliar o índice e as consequências decorrentes, conforme exposto por Guimarães e Rimoli (2006), há em muitos países no mundo uma epidemiologia de assédio moral no trabalho.

A Fundação Europeia para a melhoria das condições de vida e trabalho, em pesquisa realizada em abril de 1997 relata que o mobbing (assédio moral no trabalho) pode afetar a cada ano, 12 milhões de empregados europeus, com uma incidência de $10 \%$ em trabalhadores temporários. Em 2002, a Espanha passa de 5,5\%, dos 12 milhões de 1997, para a alarmante cifra de $11.4 \%$ dos casos europeus. A Organização Internacional do Trabalho (OIT), em 1998, estimou uma prevalência de mobbing na Europa de 5,0\% e após um ano, um aumento para $7 \%$ (Guimarães e Rimoli (2006, p. 187).

Krein (2018) corrobora que a fragilização da regulação pública em favorecimento da privada, no Brasil será potencializada com a atual reforma trabalhista implantada recentemente. E aponta como consequência derradeira a desconstrução dos direitos e proteção social.

Como a lei $n^{\circ}$ 13429/17 ainda necessita de regulamentação que envolve modificações infraconstitucionais as possíveis interpretações jurídicas geram controvérsias que impactam a definição de jurisprudências. Esse fato poderia demonstrar que haverá muitos embates nos três poderes e que a caracterização das relações formais de trabalho estaria longe de resolução. Entretanto, há mecanismos não ditos que certamente perenizarão o alcance de objetivos neoliberais. A celeridade dessas medidas, implantadas em 2019, já está em curso com a extinção do Ministério do Trabalho e Emprego, para ser implantada com desmembramento de suas funções para outros ministérios do Executivo. Certamente as consequências afetarão várias esferas que envolvem o desenvolvimento social e o Bem Comum. Segundo Krein estariam entre elas a desestruturação do mercado de trabalho; a precarização do trabalho; a fragilização da ação sindical que não receberá os insumos obrigatórios; os efeitos sobre os fundos públicos relacionados à seguridade e; sobretudo as condições de saúde e segurança no trabalho.

Ainda é uma incógnita a sequência deste fenômeno nos anos a seguir. Não parece promissor, na medida em que o novo executivo, tem verbalizado elogios à flexibilização da legislação trabalhista em curso e defenda a implantação de reforma previdenciária com alterações. O próprio presidente em exercício, em 
2019, entretanto, é constantemente desmentido e/ou corrigido por membros de sua equipe, nas afirmações que faz. Sendo assim, é preciso aguardar não apenas a apresentação de projeto de reforma pelo executivo, mas sua tramitação no legislativo e os diversos passos do judiciário, para a avaliação das possíveis novas situações eliciadoras de sofrimento psíquico relacionado ao trabalho. Essas novas situações podem ser analisadas com base nas dimensões da Psicodinâmica do Trabalho, proposta por Dejours (1994) a partir dos níveis de Representação Social apresentados por Doise (2002).

\subsection{Sobre Psicodinâmica do Trabalho e Representações Sociais.}

\subsubsection{Psicodinâmica do Trabalho: Burnout e estratégias de defesas.}

Desde a década de 1970 o fenômeno denominado burnout tem sido alvo de pesquisas acadêmicas, sobretudo nos Estados Unidos. O termo nomeia a síndrome relacionada ao esgotamento por sofrimento psíquico no trabalho e, supunha-se desde então que estivesse efetivamente vinculado à percepção que as pessoas têm em relação ao seu contexto e condições de trabalho. As relações interpessoais receberam um foco de atenção nestes estudos. Uma proposta acadêmica importante ao longo da década de 1980 surgiu com os estudos de Maslach e Jackson (1981). Para as autoras "Burnout is a syndrome of emotional exhaustion and cynicism that occurs frequently among individuals who do 'people-work' of some kind. A key aspect $f$ the burnout syndrome is increased feelings of emotional exhaustion" (p. 99). Além disso, Malasch e Jackson acreditam que os trabalhadores com a síndrome de burnout sentem-se infelizes consigo próprios e insatisfeitos com suas realizações no trabalho.

Três são os fatores propostos pelas autoras para o estudo da síndrome. São eles: Exaustão Emocional (EE); Despersonalização (DE); e, falta de Realização Pessoal (rRP). Esse constructo surgiu da ideia de que os burnout decorre de uma reação aos estressores crônicos sem a utilização adequada de estratégias de defesa. Assim, a Exaustão Emocional ocorre como consequência de altas exigências no âmbito do trabalho; a Despersonalização aparece caracterizada por dificuldades no que se refere às relações interpessoais no cotidiano de trabalho; e, a redução da Satisfação Pessoal é registrada pela frustração profissional. Silva et al (2015) 
ampliam estas discussões ao propor a utilização da Teoria do Intercâmbio Social supondo como importante analisar "o quanto o indivíduo percebe a justiça ou a reciprocidade nas relações sociais" (p. 133).

Dejours (1993) enfatiza a necessidade de identificação das raízes do sofrimento no trabalho e, através da Psicodinâmica do Trabalho procura compreender a relação do trabalhador com esse sofrimento, e o contexto do trabalho como possível ofensor à saúde do trabalhador. Dejours (1992) afirma que quando a relação do homem com o conteúdo significativo do trabalho é bloqueada por alguma circunstância, ocorre a incidência de sofrimento. Esse sofrimento gera insatisfação que afeta a subjetividade.

Dejours (1994) também distingue o conceito de sofrimento patogênico do conceito de sofrimento criador. O sofrimento patogênico surge quando todas as possibilidades de organizar o trabalho já foram tentadas anteriormente sem lograr êxito. Seria análogo às características do burnout pelo fato de as estratégias defensivas utilizadas não forem adequadas. Para ele, se, no entanto, as ações no trabalho são criativas, torna-se possível modificar o sofrimento para uma estruturação positiva da identidade. E neste sentido, o trabalho pode ser o mediador entre a saúde e a doença.

Como tolerar o intolerável? É a pergunta que Dejours (2005) lança ao discutir a banalização da injustiça social. O emprego seguro ou a sua disponibilidade são questões levantadas pelo autor que articula a situação com o papel do trabalho na identidade.

Indubitavelmente, quem perdeu o emprego, quem não consegue empregar-se (desempregado primário) e passa pelo processo de dessocialização progressivo, sofre. E sabido que esse processo leva à doença mental ou física, pois ataca os alicerces da identidade. Hoje todos partilham um sentimento de medo - por si, pelos próximos, pelos amigos ou pelos filhos - diante da ameaça de exclusão (p. 19).

Para ele, por um processo de clivagem, uma parte da população não acredita no binômio desemprego-injustiça. Essa descrença dá um cunho de resignação porque se justifica o problema da falta de emprego como um fenômeno sistêmico vinculado à fatores econômicos. E, esse fato diminui o ímpeto para ações coletivas de indignação social. Sendo assim, ao ser ignorado esse tipo de injustiça, não há uma percepção do sofrimento alheio o que potencializa a banalização da injustiça social e promove as "ideologias defensivas". Inspirado na visão de 
Hanna Arendt de banalização do mal, Dejours (2005) propõe sua Psicodinâmica do Trabalho, oriunda da análise psicodinâmica das situações de trabalho, que prioriza estudos pelo viés psicossocial.

Por que o discurso economicista que atribui o infortúnio à causalidade do destino, não vendo responsabilidade nem injustiça na origem desse infortúnio, implica a adesão maciça de nossos concidadãos, com seu corolário, à resignação ou à falta de indignação e de mobilização coletiva? Para responder a essa pergunta, creio que a psicodinâmica do trabalho, que tem implicações nos campos psicológico e sociológico, pode nos trazer algumas luzes (p. 20-21).

Segundo Dejours (2005) as ideologias defensivas se relacionam com as estratégias coletivas de defesa, mas no relato em questão, se configuram como potencialização da banalização do mal, embora sirvam como suporte viril para aqueles que fazem o "trabalho sujo". Trata-se da atitude de gestores que exercem cargos de responsabilidade que envolve ações para reduzir despesas na empresa ou da atitude de governantes e legisladores diante da redução de benefícios sociais. O autor denomina esse fenômeno como "estratégia coletiva de defesa do cinismo viril” (p. 90) e o articula com o conceito de racionalização em seu sentido psicológico como aquele que designa a defesa que "consiste em dar uma experiência, a um comportamento ou a pensamentos reconhecidos pelo próprio sujeito como inverossímeis (mas dos quais ele não pode prescindir) uma aparência de justificação, recorrendo a um raciocínio especioso, mais ou menos obscuro ou sofisticado" (p.72).

Onde há algoz, há condenados à manutenção da injustiça. Dejours (2005) aponta o comportamento das vítimas a serviço desta racionalização na medida em que o "trabalho sujo" oriundo do realismo econômico os adoece e os amedronta.

Veem-se, por toda parte, práticas que lembram o tráfico de escravos, seja na construção civil, seja na manutenção de usinas nucleares e químicas, seja nas firmas de limpeza: a terceirização em cascata leva por vezes à constituição de uma 'reserva' de trabalhadores condenados à precariedade constante, à subremuneração e a flexibilidade alucinante de emprego, o que os obriga a correr de uma empresa para outra, de um canteiro de obras para outro, instalando-se em locais provisórios, em acampamentos nas imediações da empresa, em trailers etc. Por estar se deslocando [...] certos trabalhadores não podem mais voltar para casa e não têm mais períodos de folga, nem férias, nem limitação dos horários de trabalho... até que uma estafa, uma doença ou um acidente os possibilite de todo de obter um emprego (p. 92). 
Desta forma, estas vítimas recorrem à racionalização da mentira construída pelo comportamento viril disseminado. E isso pode conduzir ao burnout em todas as suas configurações.

As estratégias de defesa individuais são insuficientes para minimizar essa violência decorrente da banalização do mal, embora tenham um significado importante na adaptação ao sofrimento, (Dejours, 2005). Via de regra, a utilização das estratégias de defesa individuais aponta para a negação da realidade, tal como "antolhos voluntários" que, em negação à percepção de riscos, optam por atitudes que lhes pareça minimizá-los com pensamentos mágicos. Destes, “alguns, em situações extremamente ansiogênicas, logram êxito. Mas outros fracassam. É nessas circunstâncias que se observam descompensações psicopatológicas” (p. 123). De acordo com a Psicodinâmica do Trabalho é necessária a construção coletiva de estratégias de defesa coletiva. E diferem daquelas estratégias coletivas de defesa do cinismo viril. A construção pelo coletivo de trabalhadores em interação que objetivam a minimização do sofrimento psíquico relacionado ao trabalho, ocorrem, de fato, quando a percepção torna consciente os riscos e o tipo de sofrimento psíquico no próprio cotidiano de trabalho.

As estratégias coletivas de defesa contribuem de maneira decisiva para a coesão do coletivo de trabalho, pois trabalhar é não apenas ter uma atividade, mas também viver a experiência da pressão, viver em comum, enfrentar a resistência do real, construir o sentido do trabalho, da situação e do sofrimento (p. 103).

Entretanto é preciso continuidade de construção sistematizada porque,

Essa construção é sempre marcada por certo grau de fragilidade, de precariedade. Notadamente quando sobrevém uma nova onda de 'reformas estruturais'. Cada nova onda desestabiliza a estratégia coletiva de defesa anteriormente utilizada e que se ajustava especificamente às condições precedentes (p. 103).

Desta forma, o diagnóstico detalhado por dimensões e níveis de representações, possibilita a coordenação da construção coletiva de defesa com intervenções focalizadas nos aspectos específicos do fenômeno.

\subsubsection{Subjetividade e representações}

Para Garcia-Roza (1985) “...a filosofia moderna constrói uma subjetividaderepresentação no interior da qual mantém as mesmas exigências e os mesmos 
objetivos do discurso platônico" (p. 10), e que, embora algumas modificações tenham sido feitas, o cerne do pensamento platônico permanece, na medida em que o mundo das ideias tenha sido substituído pela subjetividade e topus uranos por cogito. É preciso rebobinar esta história para compreender a citação.

Por que existe alguma coisa ao invés do nada? Tanto quanto na filosofia grega antiga, no pensamento atual essa dúvida aparece como relevante. Compartilha-se da visão de Koyré (1991) no que se refere à proposição de que os problemas da ciência atual remetem, ainda, à tentativa de responder à "ordem délfica de Sócrates: conhece-te a ti mesmo, responde às perguntas: Quem sou? E onde estou? O que significa ser e o que é o mundo? E enfim, o que faço e o que devo fazer neste mundo?” (p. 26). Isto posto, cabe relembrar um dos possíveis inícios de duas das vertentes de tomada de posição epistemológica: o primado do sujeito e o primado do objeto.

É possível considerar Platão e Aristóteles como aqueles que caminharam soberbamente para que esta ordem délfica socrática se tornasse a grande discussão epistemológica. A filosofia platônica é centrada na alma. A verdade só existe no interior da alma. E os adeptos da filosofia de Platão supõem que o homem não é dotado de pensamento, "mas a alma pensa e percebe a verdade" (p. 32). Esta visão caracteriza o primado do sujeito. Na filosofia aristotélica o desejo subjacente é o do saber científico. Desta filosofia consta o interesse pela física e pelas ciências naturais. Para Aristóteles o mundo é um conjunto estável de naturezas que possui existência própria. $\mathrm{O}$ mundo em si não muda. Portanto, a verdade existe nele próprio. Para esta visão filosófica o mundo, então, é mais relevante do que a alma, que Platão priorizou, ressaltando, assim, o primado do objeto.

Sugere-se que tenha sido Sócrates o autor da afirmação de que existe a ideia de conceito na mente humana. Esta afirmação deu margem a que se perguntasse a origem deste conceito. Estaria o conceito desde o início na mente ou surgiu posteriormente? Platão "ensina que nada se pode aprender senão o que já se sabe e Aristóteles julga que nada se pode saber senão o que se aprendeu. E também que só se pode aprender alguma coisa se houver alguém que a tenha aprendido antes de nós, que a sabe e que nos transmite - nos impõe - esse saber" (KOYRÉ, 1991, p. 40/41).

A visão de Koyré opta pela solução tomista que supõe a individualidade espiritual e a personalidade humana como possíveis. Para ele, o espaço real se 
identifica com a geometria, e o movimento é considerado como uma translação de um ponto a outro na ciência moderna. Na física aristotélica, a percepção sensível é diferente dos conceitos matemáticos, e o movimento é entendido em dois planos: no terrestre e no celeste. No terrestre, os corpos se movem em linha reta; no celeste, em círculos. Sendo assim, os fenômenos que se manifestam na superfície da Terra seriam afetados pelo movimento desta. Uma pedra "lançada ao ar jamais cairia no lugar de onde tivesse partido, uma vez que, durante o tempo de sua queda ou de seu voo, esse lugar ter-se-ia afastado rapidamente e se encontrasse em outra parte" (p. 187). O conceito de Galileu supera o aristotélico. No entanto, Galileu mudou a própria concepção inicial. Pensou no movimento em termos de velocidade e de direção, enquanto a maior parte dos pensadores coetâneos a ele o faziam em termos de esforço (impectus) e do deslocamento. O ponto central da importância que Koyré dá à revolução galileana na história da ciência é o de que tratar o pensamento em termos de esforço e do impectus significa imaginá-lo e não pensá-lo. Para ele, imaginar é tarefa do senso comum, e à ciência cabe pensar.

No diálogo sobre Deus e a ciência empreendido pelo filósofo Guitton com os físicos Bogdanov (1993), os autores concluem que "estamos no limiar de uma revolução de pensamento, de uma ruptura epistemológica não experimentada pela filosofia desde vários séculos (...) através da via conceitual aberta pela teoria quântica, emerge uma nova representação de mundo...” (p. 6). E associam realidade ao pensar. Para eles "o mundo objetivo parece não existir fora da consciência que determina as suas prioridades. O Universo que nos cerca torna-se cada vez menos material; não é mais comparável a uma máquina, mas antes a um vasto pensamento" (p. 22). E como eles contam esta história? Escolheram o tempo de longa duração para percorrê-la. Mostram-nos que a Física, antes dos anos de 1900, vincula a realidade aos estudos sobre a matéria, que é definida de um modo simples. Quando uma pedrinha se quebra, obtém-se uma poeira com moléculas formadas de átomos supostamente indivisíveis. No início dos anos de 1900, a teoria quântica aponta que, para compreender a realidade, é necessário renunciar à concepção tradicional de matéria e supor que o espaço e o tempo são ilusões. Uma partícula de matéria, segundo esta visão, pode ser detectada em dois lugares ao mesmo tempo. Portanto, a realidade fundamental não é cognoscível. Isso remete à Teoria do Conhecimento, que iniciou este texto pelo dito de Garcia-Roza. Guitton 
e os Bogdanov, entretanto, nos brindam com um novo saber. Os autores mostram que desta discussão da Física decorre uma ruptura na história da ciência. O filósofo e os físicos supõem que um tipo de pensamento metalógico sobrepõe-se ao pensamento lógico. Segundo eles, tal deslocamento é importante porque,

Enquanto o campo de pensamento lógico se limita à análise sistemática dos fenômenos desconhecidos - mas, afinal, cognoscíveis -, o pensamento incognoscível situa-se além das linguagens, além mesmo das categorias do entendimento: nada perdendo de seu rigor, toca o mistério e se esforça por descrevê-lo (p. 9).

Nesta interpretação, existem limites físicos ao conhecimento porque a realidade é cercada por fronteiras que, embora progressivamente identificadas e calculadas, são absolutamente inultrapassáveis. Assim, a Teoria do Big Bang, que se vincula à Teoria Quântica e tenta responder o porquê da existência de alguma coisa ao invés do nada - ou, em outras palavras, explicar o aparecimento do Universo -, é uma interpretação metalógica. Baseia-se em três conceituações do pensamento metalógico do físico Max Planck. Tais conceituações referem-se à constante de Planck, ao comprimento de Planck e ao tempo de Planck. Este último, o tempo de Planck designa a menor unidade de tempo possível e representada numericamente por $10^{-43}$. Um espaço de tempo inimaginavelmente pequeno, pois o algarismo 1 é precedido de 43 zeros. Segundo Guitton, I. Bogdanov e G. Bogdanov (1993), “aceitar esta conclusão é descobrir que existe uma solução alternativa para a estranheza física: a estranheza lógica” (p. 11).

Mas afinal do que trata a Teoria do Big Bang? É possível dizer que se trata de contar a história dos últimos 15 bilhões de anos. Seria como retroceder ao tempo zero e explicar a origem de tudo o que existe hoje. E é disso que trata o diálogo entre o filósofo e os irmãos Bogdanov. Eles contam essa história com perguntas e tentativas de respostas, em um diálogo, quase duelo, que intriga e esclarece tal como uma conversa maiêutica.

Muitos objetos são usados no cotidiano por várias pessoas sem que disso resulte uma curiosidade sobre qual força os tenha dotado das formas que apresentam hoje. Faz-se uso do objeto no momento que se precisa dele. Tais objetos, por mais familiares que sejam ao seu usuário, podem, por outro lado, conduzir a grandes enigmas. Uma chave de ferro, como o exemplo citado pelos autores, é um objeto muito usado diariamente por um grande número de pessoas. 
Ninguém precisa retroceder no tempo e refazer a história dos átomos que a compõem para abrir uma tranca ou acionar uma ignição com esta chave de ferro. Entretanto a ciência precisa, pois é na busca da compreensão dos fenômenos do Universo que sacia a sua curiosidade.

Assim, o que seria encontrado na história invisível desta chave? É possível retroceder a alguns anos e verificar que esta chave estaria no âmago de uma rocha na forma de minério bruto. E com esta resposta estaria encerrada a dúvida sobre a história da chave de ferro. O bloco de ferro que deu origem à chave existia dentro da rocha havia bilhões de anos. E esse novo dado mostra que o metal da chave pode ser mais antigo do que a própria Terra, cuja idade é estimada em 4,5 bilhões de anos. E, como o ferro é considerado o elemento mais estável do Universo, afirma a Física que, antes da existência da Terra ou mesmo do Sol - há cerca de oito ou dez bilhões de anos -, o metal da chave já flutuava no espaço interestelar, sob a forma de uma nuvem. E esta nuvem continha quantidades de elementos pesados necessários à formação do próprio Sistema Solar. Admitindo-se que esta chave, outrora, existia sob a forma de átomos de ferro perdidos em uma nuvem de matéria nascente, cabe-se perguntar de onde surgiu esta nuvem? Os físicos, sem dúvida, responderiam, facilmente, que a nuvem surgiu de uma estrela, de um sol que já existia antes do sol da Via Láctea e que explodiu, há dez ou 12 bilhões de anos.

Nessa época, o Universo era essencialmente constituído de imensas nuvens de hidrogênio que se condensaram, se reaqueceram e acabaram por acender-se, formando as primeiras estrelas gigantes. (...). No fim de uma vida relativamente breve - apenas algumas dezenas de milhões de anos -, essas estrelas gigantes explodem, projetando no espaço interestelar os materiais que servirão para fabricar outras estrelas menores, chamadas estrelas de segunda geração, assim como seus planetas e os metais que eles contêm (GUITTON; BOGDANOV; BOGDANOV, 1993, p. 22).

Tudo que se encontra na terra atualmente, inclusive a chave de ferro, segundo esta concepção da ciência, seria apenas o resíduo gerado pela explosão dessa antiga estrela. Entretanto, a explosão dessa estrela pode ser entendida como o Bang dessa história, mas ainda não tão Big. Para chegar ao Big Bang é preciso retroceder ainda mais um pouco no tempo. Ou será preciso retroceder mais um muito? Afinal o que aconteceu há 15 bilhões de anos ou há $10^{-43}$ no tempo de Planck? 
Os Bogdanov explicam que haveria no tempo zero uma singularidade microcósmica no vácuo, impensavelmente pequena, que reuniria planetas, sóis e galáxias aos bilhões. A Física moderna aponta, então, que o Universo surgiu a partir de uma explosão - o Big Bang -, que provocou a expansão da matéria. As galáxias afastam-se uma das outras sob o impulso desta explosão. Tal fenômeno de expansão, segundo esta teoria, continua até hoje. Desta forma, bastaria medir a velocidade de afastamento dessas galáxias para poder retroceder ao tempo zero da singularidade microcósmica “...como se víssemos um filme ao contrário. Rebobinando o grande filme cósmico imagem por imagem, acabaremos por descobrir o momento preciso em que o Universo inteiro tinha o tamanho de uma cabeça de alfinete" (GUITTON; BOGDANOV; BOGDANOV, 1993, p. 23).

Os astrofísicos tomam como origem de todo o Universo e do que ele contém - inclusive a chave de ferro - os primeiros bilionésimos de segundo que se seguiram à criação. Os eventos, segundo este paradigma, sucediam-se em um ritmo de tal imensidão que durante esses bilionésimos de segundo aconteceram mais coisas do que nos bilhões de anos que se seguiram. Então, após o instante original, entre $10^{-35}$ segundo e $10^{-32}$ segundo, surgiu a era inflacionária. Esta fase recebe este nome porque o Universo, que teria o tamanho de um núcleo atômico, infla por um fator de $10^{50}$. A grandeza da expansão do Universo, nesta era inflacionária, pode ser comparada ao tamanho de uma maça de dez centímetros de diâmetro. Este foi o momento culminante da expansão do Universo desde a grande explosão inicial. Desde a era inflacionária até hoje o Universo aumentou por um fator de $10^{9}$. No instante $10^{-32}$ segundo, existia apenas uma partícula, denominada "partícula X", que veicularia um campo de forças sem, entretanto, a matéria. Foi no momento $10^{-31}$ segundo que as partículas $\mathrm{X}$ dão origem às primeiras partículas de matéria que, por sua vez, dão origem a flutuações de densidade, através das quais surgem irregularidades de todos os tipos. O Universo mede, então, treze metros de diâmetro, e sua temperatura é extremamente alta. Ao mesmo tempo em que ocorre a expansão do Universo, ocorre também o seu resfriamento. E essa história invisível percorrida até então, durou o equivalente a cerca de três minutos no tempo de Planck. Durante milhões de anos o Universo permanece em radiações e em um gás turbulento. As primeiras estrelas se formam em meio a estes imensos turbilhões de gás. No núcleo das estrelas os átomos de hidrogênio e de hélio se fundem para dar origem aos elementos pesados, como o 
ferro daquela chave. Esta seria a história invisível da chave de ferro. Os Bogdanov, astrofísicos adeptos da teoria quântica, encerram a possibilidade de respostas à retomada da pergunta inicial do teólogo Guitton: Por que existe alguma coisa ao invés do nada? E Guitton permaneceu sem resposta por parte da ciência astrofísica, o que permitiu, na sequência, afirmar seu ponto de vista teológico de que quanto mais a Ciência avança, mais se aproxima de Deus.

Em 1932, na nova série de conferências, embora não proferidas, Freud (1932, sd) pondera que

nenhum leitor de um trabalho sobre Astronomia se sentirá fraudado e superior à Ciência se lhe mostram os limites entre os quais nosso conhecimento do Universo se desvanece no nebuloso. Só em Psicologia sucede coisa diferente; neste setor se manifesta plenamente a incapacidade constitucional do homem para a investigação científica (FREUD, 1932, sd, p.8).

A psicanálise conduz a qual concepção do Universo? Ao responder a esta interrogação, Freud aponta que a Weltanschauung (concepção do Universo) "é uma construção intelectual que resolve unitariamente, baseada em uma hipótese superior, todos os problemas de nosso ser e na qual, portanto, nada fica por responder, e tudo o que desperta nosso interesse encontra o lugar determinado" (FREUD, 1932, sd, 167). E após discutir criticamente as concepções do ponto de vista da religiosidade e da visão político-econômica do marxismo, afirma que a psicanálise é

Incapaz de criar uma concepção do Universo a ela peculiar. Não o necessita; é uma parcela da ciência, e pode agregar-se à concepção científica do Universo. Porém, esta mal merece nome pomposo, pois não concebe tudo, está bastante imperfeita e não aspira a concretização nem a formação de sistemas. (...). Uma concepção do Universo baseada na Ciência tem, fora da acentuação do mundo exterior real, traços essencialmente negativos, como a limitação à verdade e a repulsa das ilusões (FREUD, 1932, sd, 192).

E a concepção de Freud sobre o tempo? É tal como esta visão teológica e astrofísica? De que forma o incognoscível e a acronia se apresentam no pensamento freudiano? Como a concepção psicanalítica imbrica passadopresente-futuro? Em Os tempos de Freud, Gondar (1995) propicia um passeio por estas questões. A recusa do tempo, segundo a autora, é o viés predominante no campo filosófico na medida em que

... a questão filosófica primordial consiste em extrair, daquilo que muda e passa, o que permanece estável e imutável. (...) Em Platão o tempo é uma imagem móvel da 
eternidade; é uma cópia imperfeita de uma ideia perfeita. (...). É certo que em Aristóteles não existe mais um mundo supra terreno de ideias puras; as essências não pairam sobre a nossa realidade, mas dela devem ser extraídas. Porém, é ainda a mesma motivação de recusa do tempo que permanece. O tempo deixa de estar submetido a uma ideia perfeita para tornar-se subordinado ao movimento" (p. 3).

$\mathrm{O}$ argumento principal apontado é o de que somente quando a recusa do tempo se ameniza nas discussões filosóficos é que passa a emergir o sujeito neste campo, condição necessária para que a temporalidade também seja problematizada. E neste sentido a visão de Descartes, seguida por Kant, Husserl e Heidegger abrem a possibilidade de discussões sobre outro prisma em relação ao tempo. Nelas inclui-se o rastreamento do tema nos escritos de Freud, segundo a autora. Neste rastreamento, três temas são relevantes: finitude, tópica temporal $e$ tempo no cogito.

Diferente da visão clássica de racionalidade, a de Freud não considera o tempo como ilusão, mas sim a eternidade, na medida em que afirma a finitude. Neste sentido, considerando-se a contribuição epistemológica de Freud, é possível dizer que esta rechaça a ideia de conhecimento completo, porque, para ele, na verdade o que reside é o desejo que impele o sujeito de perceber o mundo. $\mathrm{Na}$ interpretação de Gondar (1995), essa percepção do mundo pelo desejo - velado à consciência - se articula com o pensamento. Sendo inconsciente, o desejo não é previsível e nem cognoscível e, assim, desfaz-se a possibilidade de infinito e absoluto. "Se nenhum saber pode ter a pretensão a um conhecimento completo, não é apenas porque o real não pode ser esgotado no simbólico, mas porque o homem desconhece o próprio desejo que o move; nesse desejo residiria a verdade, como um próprio do homem que é, em si mesmo, incognoscível” (p. 9).

No que se refere à tópica temporal, cabe lembrar que, por tópica, Freud denomina a diferenciação das localizações psíquicas em esquemas. Tópica, ou tópico, no vocabulário da Psicanálise de Laplanche e Pontalis (2001) é definida como,

Teoria ou ponto de vista que supõe uma diferenciação do aparelho psíquico em certo número de sistemas dotados de características ou funções diferentes e dispostos em uma certa ordem uns em relação aos outros, o que permite considerálos metaforicamente como lugares psíquicos de que podemos fornecer uma representação figurada espacialmente (p. 505). 
Sendo assim, não seria uma discussão sobre o espaço e não sobre o tempo? Três aspectos respondem esta dúvida. O primeiro se refere à suposição de que, se o aparelho psíquico é um sistema que funciona em uma certa ordem, cabe trazer a categoria tempo para a teorização sobre as tópicas freudianas.

O segundo aspecto, conforme mostra Gondar (1995), decorre da visão de que, ao valorizar a diferenciação qualitativa e específica em funcionamento, Freud está dando outro sabor à tópica que não o espacial. Neste caso, o valor exaltado é função e relação.

Um apontamento importante de Laplanche e Pontalis (2001) sobre esta argumentação traz a concepção de inconsciente para esta discussão.

...o próprio inconsciente, compreende uma organização por camadas, a investigação analítica faz-se necessariamente por determinadas vias que supõem uma determinada ordem entre os grupos de representações. A organização das lembranças, arrumadas em verdadeiros 'arquivos' ao redor de um núcleo patogênico, não é apenas cronológica; tem também um sentido lógico, pois as associações entre as diversas representações realizam-se segundo modalidades diversas (p. 506).

O terceiro aspecto, tomado emprestado do psicanalista francês Jacques Lacan por Gondar (1995), se refere à ideia de processos psíquicos, que é compreendida como conjunta à interpretação estrutural, condição necessária para a compreensão do movimento e rearranjo do inconsciente. Neste caso, mais um argumento para incluir a visão temporal da tópica.

Sobre o tempo no cogito, sintetizando Descartes e Kant, Gondar (1995) mostra a subversão freudiana ao cogito. Sobre a posição cartesiana das quatro fontes de conhecimento - memória, sentidos, conhecimento objetivo do mundo e conhecimento das essências -, é argumentado que sempre se interpõe uma dúvida que refuta a confiabilidade. Sobre a memória, esta oposição menciona a impossibilidade de garantir a continuidade de ideias. Aos sentidos, sugere-se que as impressões sensíveis estão sujeitas à transitoriedade. Ao conhecimento objetivo do mundo indica-se a alternância entre sono e vigília. E quanto à essência, o surgimento inusitado de um gênio maligno que falseasse a realidade. Só excluindo a categoria tempo seria possível tratar estas fontes com a confiabilidade necessária, tentativa realizada por Descartes, mas sem lograr êxito, escreve Gondar (1995). "O fato é que Descartes se desvia do tempo a cada passo de suas 
Meditações" (p. 18). E aponta os escritos kantianos como reforçadores dessa ideia. Se em Descartes há uma relação direta entre determinante e determinado, Eu penso - Sou uma coisa que pensa, em Kant não há possibilidade que se configure esta relação porque "a forma pela qual a existência indeterminada é determinável só pode ser a forma do tempo" (KANT, citado por GONDAR, 1995, p. 19).

A subversão freudiana ao cogito ocorre, nesta história do tempo em Freud, entre a primeira e a segunda tópica. E, novamente insere-se a visão cartesiana para a argumentação em oposição. Em Freud o sujeito se identifica com a consciência pela, também, identificação com o cogito. Considerando-se o inconsciente, o sujeito não pode ser em um tempo contínuo, mas a posteriori, na medida em que Freud aponta para a consequência do trabalho das pulsões e também para a constatação de que os impulsos chegam, eventualmente, como se fossem de estranhos. A compulsão à repetição, decorrente da sequência dos estudos de Freud, é justamente o conceito que permite reinserir ao cogito a temporalidade retirada em Descartes. E considerando que o pensamento freudiano nesta questão também difere do apontado por Kant, Gondar (1995) mostra que "o sujeito kantiano não é inconsciente e o inconsciente freudiano não é transcendental” (p. 22).

Com base nesta descrição do tempo em Freud, é possível pensar em uma teoria freudiana do tempo? Para Gondar (1995) existem duas versões de teorização de Freud em relação ao tempo. Uma negativa - e é a mais conhecida -, que aponta os processos atemporais. E a outra a positiva, menos discutida, mas que se relaciona à modalidade temporal da consciência.

Sobre a atemporalidade do inconsciente, são relevadas três asserções que aparentemente se traduzem pelo mesmo significado. "Os processos mentais inconscientes não são ordenados temporalmente; o tempo de modo algum os altera; e a ideia de tempo não lhes pode ser aplicada" (GONDAR, 195, p. 30). Na análise da autora, e considerando os diferentes significados das asserções, a primeira e a terceira são rechaçadas na medida em que à ideia de processo está implicada, necessariamente, a existência temporal. Em relação a asserção de que $o$ tempo de modo algum os altera, a argumentação é parcimoniosa porque a autora questiona: 
É possível se pensar em processos que não se desgastam (...) mesmo assim, se esses processos consistem na articulação de representações inconscientes, que podem ser a qualquer momento rearranjadas, é difícil conceber que alguma modalidade temporal não esteja implicada nesses rearranjos (p. 30).

Sobre a versão positiva referida a consciência e tempo, dois aspectos são apontados. O primeiro relaciona-se ao tempo vivido, e o segundo, à destituição da consciência. O tempo vivido é caracterizado como algo intrínseco à subjetividade e, sendo assim, é uma experiência não compartilhável e relacionada à consciência. Ao tratar da destituição da consciência, a autora mostra as duas camadas da consciência do sistema Pcpt-Cs. A primeira funciona como um escudo protetor do excesso de estímulo, e a segunda camada, como a superfície que recebe os estímulos já abrandados. Entretanto, o sistema Pcpt-Cs, ao receber as estimulações, não retém qualquer traço, dependendo dos sistemas mnemônicos pré-conscientes e inconscientes que teriam esta função com a participação protagonista do Ego na classificação das excitações. E somente durante a classificação que a consciência emerge, para, posteriormente, extinguir-se. Ao tratar a consciência como instantes a serviço de outras instâncias do psiquismo, Freud abandona a consciência para firmar o inconsciente como objeto de estudo.

No escopo de sua análise do tema, Gondar (1995) pondera que há uma mistura na concepção de tempo nos escritos de Freud. O tema aparece em cinco discussões. A primeira refere-se à concepção de representação no funcionamento do sistema percepção-consciência. A segunda é tratada na lógica temporal do modo inconsciente de operação. O tempo da pulsão é a terceira. A quarta compreende três outras acepções: a do tempo mítico, tempo das origens do psiquismo e da constituição do sujeito. E, por último, a existência da herança arcaica no psiquismo. Ao descrever mais amiúde cada uma destas cinco discussões, a autora conclui: "Pensar o tempo sob a égide da disjunção e da diferença; fornecer um estatuto teórico ao puro devir, como fonte de modalidades temporais diversas; postular um determinismo a posteriori, com uma plasticidade sem precedentes na esfera científica" (p. 133).

Mas afinal, o que é o aparelho psíquico em Freud? O que são os sistemas $\varphi$, $\psi$ e $\omega$ ? E do que tratam, efetivamente, os sistemas Ics, Pcs e Cs. Como estão inseridos memória, percepção e representação nestes sistemas? 
Ao contar a história do Projeto de Freud, escrito em 1895, mas efetivamente publicado em 1950, Garcia-Roza (1991) ressalta que a concepção deste trabalho visou apresentar a psicologia como ciência natural. Este fato parece "remar contra a maré" expressada à época pela Fenomenologia do Espírito de Hegel e pela Psicologia Comparada de Dilthey. Por quê? A visão da época associava as ciências da natureza às categorias de significação e força. Entretanto, Garcia-Roza pontua várias ideias convergentes entre Herbart e Exner, ambas de concepções quantitativas, com as apresentadas por Freud, no Projeto e em outros escritos. Vale ressaltar que esta visão freudiana da psicologia como ciência natural traduzse por sua inserção no cenário positivista da época, mas com interseção, embora não claramente denominada, com a filosofia do espírito. Mas o foco principal de Freud nesta postulação diz respeito à exigência de rigor teórico-conceitual, do qual ele nunca descuidou.

Duas são as ideias que norteiam o Projeto. A primeira pretendia conceber uma lei geral do movimento para diferenciar atividade e repouso. A segunda preceitua que os neurônios são partículas materiais. E, embora estas ideias não fossem originais, pois foram estudadas anteriormente, no trabalho de Freud adquirem uma nova configuração porque são articuladas entre si, estabelecendo uma diferença estrutural. Assim sendo, no Projeto os neurônios $\varphi, \psi$ e $\omega$ são descritos com visão sistêmica. A proposta de Freud utiliza, portanto, um modelo sistêmico de natureza hipotética que se caracteriza como uma teoria neuronal sem pretensão de apresentar uma descrição anatômica do neurônio, que era o interesse da histologia da época. Ao contrário, Freud pretende apresentar uma metapsicologia. “Os neurônios são condutores de energia, sendo que dependendo do sistema por eles formado, são capazes de armazenar energia" (GARCIAROZA, 1991, p. 80).

Com base nos casos de histeria e de neurose obsessiva, Freud "levanta a hipótese de uma proporcionalidade entre a intensidade dos traumas e a intensidade dos sistemas por eles produzidos" (GARCIA-ROZA, 1991, p. 83). E, a partir disto, propõe a distinção entre quantidades e intensidades e, em seguida o princípio da constância que se relaciona à regulação da intensidade.

Um aspecto interessante desta temática relacionada ao princípio da constância se refere à noção de investimento, que designa uma representação cujo afeto não foi descarregado. Nesta discussão surge uma relação entre o princípio da 
inércia e o princípio do prazer. E, apontando o evitar do desprazer, Garcia-Roza mostra que "o desprazer é identificado com o aumento do estímulo, enquanto que o prazer resulta de sua diminuição. Como o princípio da inércia neurônica enuncia a tendência do neurônio a aliviar-se da quantidade, somos tentados a identificar o princípio de inércia com o princípio de prazer" (GARCIA-ROZA, 1991, p. 90).

Entretanto, o próprio Freud percebe a necessidade de substituir o princípio da inércia pelo da constância para a regulação dos processos psíquicos. E é deste estudo que surge a distinção entre processos primários e processos secundários, que posteriormente, por sua relação temporal, terão papel fundamental na definição de ego $(\mathrm{Eu})$ como resultado da diferenciação progressiva do id (Isso). Esses processos, entendidos como modos de funcionamento do aparelho psíquico, podem ser entendidos de duas formas, segundo Laplanche e Pontalis (2001). De um lado, descrito pela visão tópica, o primário refere-se ao sistema inconsciente, e o secundário pelo sistema pré-consciente-consciente. Na segunda forma, tratado pela visão econômico-dinâmica, no processo primário ocorre o livre escoamento da energia psíquica, e no secundário a energia escoa de forma controlada. Em ambos os processos, a representação tem funções diferentes. No primário, após o escoamento a representação é transferida de um ponto a outro pelos mecanismos de deslocamento e de condensação. No secundário, "a energia começa por estar 'ligada' antes de se escoar de forma controlada: as representações são investidas de uma maneira mais estável, a satisfação é adiada, permitindo assim experiências mentais que põem à prova os diferentes caminhos possíveis de satisfação" (p. $371)$.

Com a leitura da interpretação de sonhos (FREUD,1900, sd) é possível compreender o fluxo destes processos. As representações ocorrem em diferentes intensidades e se tornam suscetíveis de derivação para outras representações que, em continuidade, geram um conjunto de representações providas de grande intensidade. Esta dinâmica é denominada condensação e é o processo pelo qual são obtidas as intensidades necessárias para o caminho que leva ao sistema de percepção. Entretanto, através da livre transferência das intensidades são constituídas representações intermediárias para além daquelas que transferem suas energias reciprocamente e, este fenômeno pode levar "a alguma coisa inaudita no curso normal das representações, no qual se trata, sobretudo da escolha e conservação do verdadeiro elemento de representação" (p. 365). 
Na sequência dos estudos sobre o Projeto associadas ao conceito de investimento estão duas hipóteses freudianas importantes no que tange ao entendimento da memória. A primeira refere-se às barreiras de contato (sinapses), e a segunda, à facilitação.

A importância para o entendimento da memória propiciada pela hipótese das barreiras de contato está no fato de que, na memória neurônica, é possível distinguir os neurônios permeáveis (neurônios $\varphi$ ) dos impermeáveis (neurônios $\psi)$. Este relacionado à memória e aquele à percepção, na medida em que a fluidez necessária no processo perceptivo requer permeabilidade. E esse aspecto está relacionado com a ideia de Freud sobre as duas características do sistema nervoso: a recepção de estímulos externos (sistema $\varphi$ ) e a descarga de excitações endógenas (sistema $\psi$ ). O sistema $\varphi$ é protegido da estimulação direta externa pela mediação dos órgãos dos sentidos, mas o mesmo não ocorre com o sistema $\psi \mathrm{em}$ relação aos estímulos endógenos. Nesta dinâmica, ocorre a mola pulsional do mecanismo psíquico.

A segunda hipótese, a facilitação, configura-se como crucial para a visão de Freud do aparato psíquico. Conforme mostra Garcia-Roza (1991), “A distinção entre neurônios permeáveis e neurônios impermeáveis é o suporte necessário para Freud conceber o sistema como um aparato de memória que se forma por estratificação sucessiva" (p. 98). Este processo da memória é constituído por facilitações na construção do trilhamento necessário para o reordenamento de novos nexos. $\varphi, \psi \mathrm{e} \omega$

Enquanto os sistemas $\varphi$ e $\psi$ são quantitativos e estão relacionados ao inconsciente, o sistema $\omega$ é qualitativo e está relacionado à consciência. A qualidade está relacionada aos aspectos sensíveis da percepção, tais como som, cor, textura; e se origina na visão de Freud, no sistema $\omega$ "que é excitado junto com a percepção, mas não com a reprodução, e cujos estados de excitação produzem as diversas qualidades - ou seja, são sensações conscientes“ (FREUD, citado por GARCIA-ROZA, 1991, p. 103). Sendo assim, é este sistema $\omega$ o responsável pela percepção-consciência. Os três sistemas atuam interativamente: $\omega$ é alimentado por $\varphi$, que fornece informações para $\psi$.

Surge uma situação, nesta primeira tópica, em que a solução de Freud reforça o rastreamento de Gondar sobre o tempo. Os neurônios $\omega$ são, na afirmação de Freud, órgãos de percepção que, entretanto, têm a permeabilidade 
implicada na fluidez necessária. Se, no caso dos neurônios $\varphi$, a permeabilidade é completa por estar em contato direto com a fonte endógena, a quantidade de energia é maior; e, no caso dos neurônios $\psi$, estes terem energia menor por sua capacidade de criar barreiras de contato; cria-se uma dúvida. Se a carga de energia recebida pelos neurônios $\omega$ é menor por ser intermediado, por que não têm a capacidade maior de criar barreiras de contato? É justamente na resposta a esta dúvida que surge a temporalidade.

Os neurônios não são capazes de receber $\mathrm{Q}$, o que eles recebem é uma temporalidade ou um período de excitação que lhes possibilita uma carga mínima de Q necessária para a consciência. (...) ele (Freud) faz uma correção do esquema anterior e afirma que existem três formas segundo as quais os neurônios podem se afetar mutuamente: $1^{\circ}$ ) transferindo quantidade (Q) entre si; $2^{\circ}$ ) transferindo qualidade entre si e $3^{\circ}$ ) exercendo uma forma de excitação recíproca (GARCIAROZA, 1987, p. 53).

Decorre deste modelo de funcionamento a noção freudiana de experiência de satisfação e, na sequência, a emergência do ego que configura a reestruturação, pela segunda tópica, da visão freudiana de aparelho psíquico. A noção de experiência de satisfação está ligada ao estado de desamparo original do ser humano, um dos principais temas retomado, de Freud, na visão winnicottiana. E, conforme mostram Laplanche e Pontalis (2001) "A vivência de satisfação - real e alucinatória - é a noção fundamental da problemática freudiana de satisfação; nela se vêm articular o apaziguamento da necessidade e a realização do desejo" (p. 531).

A segunda tópica, embora não represente uma ruptura no conjunto da teoria psicanalítica, aponta o interesse para outras direções que não as da percepção e consciência. Os conceitos de ego, id e superego (Eu, Isso e Supereu). Assim, o ego, nesta versão, tem sua origem no sistema Pcpt-Cs e do seu núcleo segue pelo Pc e pelo Ics. Sendo o id a porção inacessível do aparelho psíquico, a função do ego, como instância duplamente modificada do id e do superego, "é servir de mediador entre o id e o mundo externo, o que coloca em confrontação os dois princípios reguladores do aparelho psíquico: o princípio de prazer e o princípio da realidade" (GARCIA-ROZA, 1987, p. 207).

E qual a pontuação contemporânea sobre a percepção e a representação? Segundo Botella e Botella (2002), os estudos sobre percepção não empreenderam um conceito preciso na psicanálise. Para os autores "nos textos freudianos, ela aparece muitas vezes reduzida a uma função elementar, utilizada antes mais 
especificamente em acepções tais como auto percepção, percepção interna ou endopsíquica, ou integrada em uma concepção teórica que considera o id como seu próprio sistema de percepção" (p. 178). Entretanto, da mesma forma que sinalizam esta falha, reconhecem a importância “que Freud dá ao retorno, durante o tratamento, da realidade do passado, da verdade histórica, sob forma de lembrança representada” (p. 179). Mas é na análise da segunda tópica que os autores outorgam a Freud o bem-posto em relação ao perceptivo. Essa coroação se dá pela constatação da prioridade em relacionar percepção e representação no estudo do psiquismo. "A segunda tópica é o produto da necessidade de poder pensar o psiquismo também enquanto conjunto dos fenômenos submetidos a mudanças; em suma, em termos de processo e não unicamente de conteúdos representacionais e de sistemas" (p. 184).

\subsubsection{Representações sociais e engendramento de instituintes}

Sobre as discussões propostas referidas à construção da realidade a partir do senso comum ou delimitada como área da ciência, Moscovici (1978) realizou um grande percurso acadêmico no âmbito das ciências sociais, com sua Teoria das Representações Sociais. Suas discussões iniciam-se, na verdade, com inspiração na sociologia molecular (MOSCOVICI, 1990). Esta sociologia molecular é pautada no conceito de redes e representações que aponta o princípio da complementaridade de Bohr ${ }^{5}$. Neste princípio a descrição dos fenômenos físicos e a descrição dos objetos atômicos invisíveis não se excluem, eles se complementam. Com base neste estudo é possível refletir sobre a lógica simbólica. O autor supõe que o verdadeiro elemento atômico da sociedade é a ação mental recíproca de onde tudo provém e para onde tudo retorna. E divide os fatos em duas classes: os fatos anônimos e os fatos nominados. Refere-se ao primeiro como os minúsculos acontecimentos e os pequenos fatos que vão sendo colecionados através da observação dos estados físicos e dos estados da alma. Quanto aos fatos nominados, aponta que só existem através de categorias que os classificam e revestem-nos de uniformidade. Assim como os átomos em física, os

\footnotetext{
${ }^{5}$ Niels Bohr - Recebeu o prêmio Nobel em 1922 por seu trabalho sobre estrutura atômica.
} 
indivíduos só têm realidade através das interações. Para ele, os costumes, as leis, as nações são manifestações na vida em comum, assim como a matéria com relação às forças atômicas que a cimentam.

Moscovici (2003) articula as ideias de pensamento primitivo, ciência e senso comum. Para ele,

a crença em que o pensamento primitivo "está baseado é uma crença no poder ilimitado da mente em conformar a realidade, em penetrá-la e ativá-la e em determinar o curso dos acontecimentos. A crença em que o pensamento científico moderno está baseado é exatamente o oposto, isto é, um pensamento no poder ilimitado dos objetos de conformar o pensamento, de determinar completamente sua evolução e de ser interiorizado na e pela mente. No primeiro caso, o pensamento é visto como agindo sobre a realidade; no segundo, como uma reação à realidade humana; em uma, o objeto emerge como uma réplica do pensamento; na outra, o pensamento é uma réplica do objeto; e se para o primeiro, nossos desejos se tornam realidade - ou wishful thinking - então, para o segundo, pensar passa a ser transformar a realidade em nossos desejos, despersonalizá-los. (...) enquanto a mente primitiva se amedronta diante das forças da natureza, a mente científica se amedronta diante do poder do pensamento (...) ambas, a seu modo, representam um aspecto real da relação entre nossos mundos internos e externos. (p. 29)

$\mathrm{Na}$ visão moscoviciana, representar alguma coisa e ter consciência de alguma coisa se assemelham em processo. A representação não se configura como uma instância intermediária, mas como um processo que engendra, de forma recíproca, percepção e conceito. Na relação com o objeto, a representação tem um status de gênese desta relação, na medida em que "a condição de seu aparecimento é uma supressão do objeto ou da entidade concreta; mas por outro lado, essa supressão não pode ser total e, a exemplo da atividade perceptiva, a percepção deve recuperar esse objeto ou essa entidade, e torná-los tangíveis" (MOSCOVICI, 2003, p. 58).

Através da Teoria das Representações Sociais, Moscovici (1978) sistematiza estas ideias. Mostra que a passagem da ciência para as das representações sociais implica uma descontinuidade, um salto de um universo de pensamento e de ação a um outro, e não uma continuidade, uma variação do mais ao menos. Constitui uma ruptura. Essa ruptura é a condição necessária para a "entrada de cada conhecimento físico, biológico, psicológico e etc., no laboratório da sociedade. Todos eles aí se encontram, dotados de um novo status epistemológico, sob a forma de representações sociais" (p. 26). Para ele, as Representações Sociais têm 
relação direta com o comportamento humano criador, na medida em que elas são dotadas de função constitutiva da realidade.

Assim, "as representações individuais ou sociais fazem com que o mundo seja o que pensamos que ele é ou deve ser. Mostram-nos que, a todo instante, alguma coisa ausente se lhe adiciona e alguma coisa presente se modifica" (MOSCOVICI, 1978, p. 59). Segundo este autor, à psicologia social coube penetrar nas representações sociais visando a descobrir sua estrutura e seus mecanismos internos socialmente compartilhados. Moscovici (2003), apoiado na antropologia e na sociologia, propõe esta abordagem teórica em psicologia social que busca circunscrever o senso comum e os saberes populares, elaborados e partilhados coletivamente. A Teoria das Representações Sociais se caracteriza como um campo de estudos sobre a construção da realidade. Pela representação social, o fenômeno passa de não familiar a familiar, tornando-se conhecido e real. Esta mudança, mesmo trazendo o peso da tradição, da memória e do passado, acrescenta elementos novos à realidade compartilhada por um determinado grupo da sociedade. Segundo o autor, o estranho atrai, intriga, perturbando as pessoas e as comunidades, provocando um medo de perda do referencial de continuidade e de compreensão mútua. Por isso, tornando o estranho familiar, mesmo este não sendo mais extraordinário, torna-se mais interessante. Para este autor, denominar alguma coisa ou pessoa é dotá-la de genealogia e incluí-la num complexo mundo de palavras específicas, localizando tal pessoa ou coisa numa matriz de identidade da nossa cultura. A Teoria das Representações Sociais considera a diversidade dos indivíduos, bem como a estranheza e imprevisibilidade de atitudes e fenômenos. Busca entender o que é estranho para tornar familiar. Moscovici indica que há universos de opinião característicos dos diferentes grupos e segmentos. Há questões que têm relevância e atualidade para alguns, mas há variados graus de consistência da informação que se hierarquizam no campo de representação quanto à atitude favorável ou desfavorável. É necessário identificar como é gerado o conhecimento e neste sentido, pode-se dizer que os conhecimentos são inerentes tanto à própria sociedade, como também oriundos de elaboração individual. Mas os indivíduos não pensam sozinhos, há participação de outras pessoas e grupos influenciando julgamentos e ideias pessoais. Essa é a origem das Representações Sociais. Aí se interconecta a "arte da conversação", permitindo a gênese das 
representações nas circunstâncias espaciais e temporais em que se manifestam. Segundo Moscovici (2003),

As representações sociais se baseiam no dito: Não existe fumaça sem fogo. (...). Quando nós vemos fumaça, nós sabemos que um fogo foi aceso em algum lugar e, para descobrir de onde vem a fumaça, nós vamos a busca do fogo. O dito, pois, não é uma mera imagem, mas expressa um processo de pensamento, um imperativo - a necessidade de decodificar todos os signos que existem em nosso ambiente social e que nós não podemos deixar sós, até que seu sentido, o fogo escondido, não tenha sido localizado. (p.79-80).

O conceito de representações sociais permitem informações diagnósticas fundamentais na medida em que "as práticas de conhecimento e do conhecimento prático desempenham um papel essencial, pois está inscrito nas experiências ou acontecimentos sustentados por indivíduos e partilhados pela sociedade." (MOSCOVICI, 2003, p. 217)

Inspirado em analogia à técnica de holografia, o conceito de holomorfia proposto por Wagner (1998) explica bem a ideia.

O caráter público requerido pelo 'pensamento' coletivo implica que as representações sociais contenham meta-informação nas representações sociais de holomorfia ou de características 'holomórficas' de uma representação. O termo implica em englobar uma classe de características das representações sociais que são resultantes diretamente da premissa de que as representações sociais são elaboradas no discurso público de um grupo reflexivo e 'pensante'. O termo se refere a aspectos relevantes de um grupo social - como um todo - que estão presentes em um sistema de conhecimento individualmente representado, mas compartilhado. (p. 13)

Sendo assim as representações sociais no âmbito do trabalho, sobre o trabalho e entre colegas de trabalho atuam holomorficamente para a consciência dos fatores que necessitam de intervenções especificadas para a diminuição do sofrimento psíquico relacionado ao trabalho. As pessoas, em seu cotidiano de trabalho tornam-se instituintes nas suas histórias e na história social.

\subsubsection{Dimensões e Níveis de Representação no sofrimento psíquico relacionado ao trabalho}


Ao estudar as representações sociais de trabalhadores sobre seu trabalho, busca-se o "fogo para descobrir de onde vem a fumaça": a penosidade no trabalho.

Com base na definição de representações sociais como uma forma de enfrentamento simbólico para compreender o não familiar, Wagner (1988) propõe que a representação social envolve a atividade discursiva e a atividade expressa. E neste sentido, ação e fala se configuram como parte integral da representação.

Sato (1994) desenvolveu uma pesquisa sobre penosidade no trabalho, partindo do referencial teórico da Representação Social e dos conceitos da Psicodinâmica do trabalho. Na pesquisa da autora, o conhecimento prático obtido de motoristas de ônibus urbanos no município de São Paulo, permitiu definir o trabalho penoso, relacionados aos contextos de trabalho gerador de incômodo, esforço e sofrimento físico e mental, sentido como demasiados, sobre os quais estes trabalhadores não tem controle. O controle sobre o trabalho é um dos aspectos já identificados em vários outros estudos como um dos principais requisitos para que o trabalho seja saudável. Ao estudar o controle a partir do conhecimento prático, Sato evidenciou, inspirada em Dejours, que, para que ele seja possível, são necessários três requisitos que devem estar presentes simultaneamente: familiaridade, poder e limite subjetivo.

Estes requisitos configuram-se como as três dimensões utilizadas como base para elaboração do levantamento de indicadores de penosidade no trabalho humano, alvo deste projeto.

O conceito de familiaridade é definido como um processo de aproximação gradativa com o trabalho, possibilitado mediante a construção de um conhecimento especifico dos próprios trabalhadores. A familiaridade possibilita prever o desenrolar do trabalho, os problemas existentes na tarefa e também como lidar com eles. Considera-se, então, que todo o período de adaptação é penoso. O poder implica a possibilidade de o trabalhador interferir e mudar prescrições que definem normas no nível da tarefa a ser por ele executada. Acarreta irritação, nervosismo e cansaço, pois o trabalhador precisa suportar uma situação incômoda ou que demande esforço e perceber que o poder de interferência na situação é restrito ou inexistente. Como limite subjetivo entende-se o conhecimento dos seus próprios limites, ou seja, quanto, quando e o que é possível suportar no trabalho. Sofre dupla determinação, pois depende ao mesmo tempo dos contextos de 
trabalho e das características de cada trabalhador. Não existe uma demarcação rígida e imutável, pois varia em função de diversos contextos de trabalho e do próprio trabalhador.

$\mathrm{Na}$ abordagem societal das representações (DOISE, 2002), a ideia principal é:

articular explicações no nível do indivíduo e explicações de ordem social, mostrando como o indivíduo dispõe de processos que lhe permitem funcionar em sociedade e, de uma maneira complementar, como as dinâmicas sociais, particularmente interacionistas, posicionais ou de valores e de crenças gerais, orientam o funcionamento desses processos. (p.1)

Para Doise (2002) a abordagem societal das representações, além de classificatória, com a distinção em quatro níveis, facilita a realização de articulações no estudo dos fenômenos. Nesta abordagem, recorre-se a quatro níveis de análise. São eles: 1) processos intraindividuais; 2) processos interindividuais e situacionais; 3) processos em grupos com status diferentes; e 4) processos relacionados aos sistemas de crenças, representações, avaliações e normas sociais.

No que se refere aos processos intraindividuais, Doise (2002) aponta que "tratam da maneira pela qual os indivíduos organizam suas experiências com o meio ambiente" (p. 2). Segundo o autor, muitos relatos de pesquisa que envolve este nível se referem a estudos sobre equilíbrio cognitivo. Em relação ao segundo nível, os processos interindividuais e situacionais, parte-se do princípio de que os indivíduos são considerados como intercambiáveis e são seus sistemas de interação que fornecem os princípios explicativos típicos das dinâmicas desse nível. No que concerne aos processos relacionados aos grupos com status diferentes, o terceiro nível, Doise considera que as diferentes posições que os atores sociais ocupam no tecido das relações sociais devem ser analisadas para verificar de que forma suas posições modulam os processos do primeiro e segundo níveis. O quarto nível analisa os sistemas de crenças, representações, avaliações e normas sociais na medida em que além de dar significação aos comportamentos dos indivíduos, também fundamentam as diferenciações sociais tomando como base os princípios gerais. Almeida (2009) sistematiza estes níveis 
de analise: 1) processos intraindividuais; 2) processos interpessoais; 3) processos intergrupais; e, 4) processos societais.

A Figura 1 a seguir, mostra as definições das dimensões e níveis de representações para a análise do estudo nesta tese de doutoramento, simplificando suas denominações.

Figura 1 - Dimensões e Níveis de Representações para Análise do Sofrimento Psíquico no Trabalho Humano, segundo Dejours e Sato, e Moscovici e Doise

\section{DIhENSÕES (DejoursiSato)}

Familiaridade: Processo de aproximaçẫo gradativa com o trabalho possibilitado mediante a construçấo de um conhecimento especifico dos próprios trabalhadores.

Poder: Implica a possibilidade do trabalhador interferir e mudar prescriçốes que definem normas no nivel da tarefa a ser por ele executada.

Limite subjetivo: Conhecimento dos seus próprios limites, ou seja, quanto, quando e o que é possivel suportar no trabalho.

\section{NÍVEIS DE REPRESENTAÇÃO (Moscovici/Doise)}

Intraindividual: Analisa o modo como os indivíduos organizam suas experiências com o meio ambiente.

Interpessoal: Centra-se nos processos interindividuais e situacionais, buscando nos sistemas de interaçẫo, os princípios explicativos típicos das dinâmicas sociais.

Intergrupal: leva em conta as diferentes posiçốes que os indivíduos ocupam nas relaçỗes sociais e analisa como essas posiçốes modulam os processos do primeiro e do segundo niveis.

Societal: enfoca os sistemas de crenças, representaçốes, avaliaçốes e nomas sociais, adotando o pressuposto de que as produccốes culturais e ideológicas, características de uma sociedade ou de certos grupos, dẫo significaçẫo aos comportamentos dos indivíduos e criam as diferenciaçốes sociais, a partir de principios gerais. 


\section{Estudo de campo}

\subsection{Delineamento}

Estudo exploratório-descritivo com abordagem quali-quantitativa.

\subsection{Sujeitos}

A pesquisa foi realizada na emergência de hospital público, no município do Rio de Janeiro. Dos 400 funcionários foram entrevistados 300, dos quais 51 protocolos foram descartados por dados incompletos, tendo como sujeitos finais 249 funcionários. Sobre o tamanho da amostra para análise da qualidade psicométrica de instrumentos, Damásio (2012) aponta que foi por muito tempo, um aspecto de divergências e controvérsias na literatura científica, principalmente em relação ao número mínimo de sujeitos necessários. Alguns recomendam (Gorsuch, e Hair e cols., citados por Damásio, 2012, p. 221), que o N deveria ser de pelo menos 100 sujeitos, e um número mínimo de cinco respondentes por item. Informa que Cattell (citado por Damásio, 2012, p. 221) argumentou que $\mathrm{N}$ igual a 250 seria o número mínimo recomendável com razão entre três e seis respondentes por item. Aponta que Everitt (citado por Damásio, 2012, p. 221) defende a quantidade de pelo menos 10 respostas para cada item, sendo que quanto maior o $\mathrm{N}$ melhor a análise. Entretanto, apesar das controvérsias e o fato de não existir experimento que corrobore ou refute nenhuma das informações, Damásio sustenta que

atualmente é fortemente aceito que a utilização de amostras grandes tende a fornecer resultados mais precisos, diminuindo o efeito erro amostral e fornecendo resultados mais próximos ao índice populacional, tanto no que se refere à estrutura fatorial, quanto à carga fatorial e a comunalidade dos itens. Porém, em relação ao tamanho mínimo da amostra, os resultados ainda são imprecisos, porque a qualidade de uma solução fatorial não depende exclusivamente do número de respondentes, mas varia de acordo com a qualidade do instrumento avaliado. (Damásio, 2012, p. 222.)

Como o instrumento em questão é composto de 12 itens, considerou-se 20 sujeitos por item suficientes, Sendo que os 249 respondentes considerados no 
estudo representam $63 \%$ do total de funcionários alocados na emergência do hospital.

Cabe uma fundamentação sobre a opção de não correlacionar os dados coletados com base nas três dimensões nos quatro níveis de representação com estado civil, como ocorre em muitas pesquisas. Decidiu-se verificar a influência de redes de apoio familiar em relação às estratégias de defesa.

Embora o viés seja o da diferenciação entre famílias pobres e não pobres no que se refere às novas configurações familiares, a argumentação de Sarti (2009) está relacionada com a pretendida articulação entre redes de apoio e estratégias defensivas coletivas, na medida em que mostra a distinção entre famílias nucleares e famílias em redes. A autora faz um caminho histórico para apontar as diferenças entre a família nuclear reforçada pela revolução industrial, que separou o mundo familiar do mundo do trabalho, e a família contemporânea, que com o advento da tecnologia médica, sobretudo, teve a dimensão escolha potencializada. Mostra a autora, neste sentido, que

Sabemos que o mundo de significações humano não tem uma relação mecânica com as possibilidades materiais da existência, sendo mediado pelas 'traduções' sociais, culturais e psíquicas dessas possibilidades, ou seja, dependem de como são incorporadas pela sociedade e internalizadas pelos sujeitos. (SARTI, 2009, p. 23)

Sarti (2009) mostra, de outro lado, a dificuldades advindas da mudança no que se refere a configuração de família. Sendo o modelo de família, aquele pautado nas concepções socialmente instituídas por dispositivos do Estado, da Igreja e da Educação, a família adquire um status de unidade biológica e naturalizada no ponto de vista nuclear, embora seja apenas idealizado e diferente do, efetivamente, vivido. Para a autora:

Embora a família continue sendo objeto de profundas idealizações, a realidade das mudanças em curso abala de tal maneira o modelo idealizado que se torna difícil sustentar a ideia de um modelo "adequado". Não se sabe mais, de antemão, o que é adequado ou inadequado relativamente à família. No que se refere às relações conjugais, quem são os parceiros? Que família criaram? Como delimitar a família se as relações entre pais e filhos cada vez menos se resumem ao núcleo conjugal? Como se dão as relações entre irmãos, filhos de casamentos, divórcios, recasamentos de casais em situações tão diferenciadas? Enfim, a família contemporânea comporta uma enorme elasticidade." (SARTI, 2009, p. 25)

O que, entretanto, se extrai de forte articulação do texto da autora com o este trabalho, é a síntese que ela apresenta sobre o papel da família "nesse jogo 
entre o mundo exterior e o mundo subjetivo, as construções simbólicas operam numa relação espetacular" (SARTI, 2009, p. 27). E esse jogo se dá desde as experiências primevas em que o componente simbólico aprendido na linguagem constitui o sujeito. E é nesta elaboração e reelaboração que ocorre a objetivação da experiência subjetiva. E o que se pode dizer em relação às redes de apoio, depois dessa explanação? Sarti (2009) mostra que é preciso desconectar os conceitos de família e unidade doméstica na nova configuração familiar, porque os recursos materiais e afetivos ultrapassam um único teto. Vão além do núcleo. E esse aspecto é o que traz a visão de redes de relações. Sarti (2009), com base em Woortmann, aponta o conceito de obrigações como aquele que fundamenta a noção de parentesco ao invés de consanguinidade. Esse eixo moral estrutura as relações na família. E, considerando que independente da classe social, essa é uma realidade na sociedade contemporânea, se vê a importância dada ao coletivo neste conceito ampliado de família em redes de relações e de apoio.

A amostragem foi baseada nos quatro Grandes Grupos - GG de ocupações da Classificação Brasileira de Ocupações - CBO, do Ministério do Trabalho e Emprego - MTE, a saber: GG2 - Profissionais das ciências GG 3 - Técnicos de nível médio, GG 4 - Trabalhadores administrativos e GG 5 - Trabalhadores em serviços. Foram incluídos na amostra, acadêmicos e estagiários, sem código específico na CBO. No GG 2, estão as ocupações de médico, enfermeiro, assistente social, dentista, fonoaudiólogo, nutricionista e psicólogo. No GG 3 estão as ocupações de técnico de enfermagem, instrumentista cirúrgico, técnico gessista, técnico em radiologia e secretária. No GG 4 estão as ocupações de auxiliar administrativo e recepcionista. No GG5 estão as ocupações de auxiliar de serviços gerais, copeiro, gari, maqueiro, segurança e vigilante. Foram considerados como estudantes, as ocupações acadêmicos e estagiários. Optou-se por definir, em reunião com a equipe gestora do hospital,-se, códigos de análise por nível de responsabilidade nas atividades da instituição hospitalar, numa escala de um a oito, para adequação da amostra. Os Médicos, do GG 2 do CBO, estão no nível 1 (n 67, 27 \%). No nível 2 estão os enfermeiros, também do GG 2 do CBO, (n 33, $13 \%$ ). Foram incluídos no nível 3: assistentes sociais, dentistas, fonoaudiólogos, nutricionistas e psicólogos, pertencentes da mesma forma no GG 2 do CBO (n 14, 6 \%). Técnicos de enfermagem, GG 3 do CBO, estão no nível 4 (n 43, 17 \%). No nível 5 estão: instrumentistas cirúrgicos, técnicos gessista, 
técnicos em radiologia e secretárias, também GG 3 do CBO, (n 10, 4 \%). No nível 6 estão: auxiliares administrativos e recepcionistas, GG 4 do CBO, (n 25, 10 \%). No nível 7 estão: auxiliares de serviços gerais, copeiros, garis, maqueiros, seguranças e vigilantes, GG 5 do CBO, (n 36, 14 \%). Finalmente, os acadêmicos, sem inclusão no CBO, estão no nível 8 (n 21, 8 \%). (tabela 2).

\section{Tabela 2 - Ocupações nos Grandes Grupos CBO e nível de responsabilidade}

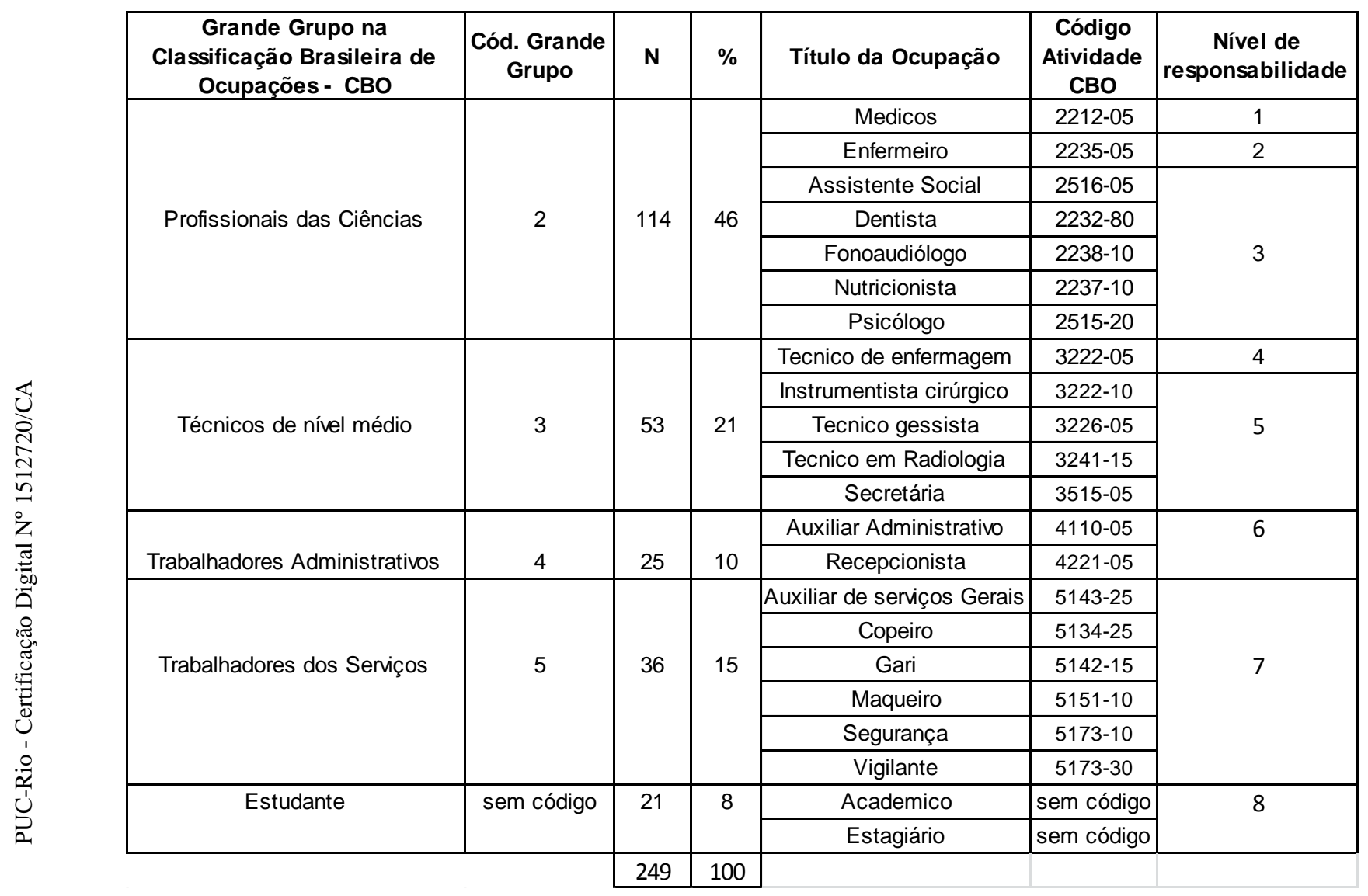

Os funcionários, sujeitos da amostra, estão alocados nos setores: Esterilização, Consultório bucomaxilo, Consultório otorrinolaringologia, Farmácia, Recepção, Consultório de nefrologia, Consultório de ortopedia, Consultório de ortopedia, Consultório de pediatria, NIR regulação, Radiologia, Centro cirúrgico, Sala verde, Sala amarela e Sala vermelha. Como há funcionários que atuam em mais de um setor, foram criados, para fins de análise, conjuntos de setores, a saber: Salas/consultório, Multi consultórios e Multi salas.

O critério nível de responsabilidade também foi utilizado para a codificação na pesquisa, numa escala de zero a 3. Foram 49 (20\%) sem especificação e por 
isso receberam nível zero como código de responsabilidade. No nível 1 estão os sujeitos que atuam no centro cirúrgico; na sala amarela e na sala vermelha (n 65, $26 \%)$. No nível 2 estão alocados os sujeitos dos setores: consultórios de nefrologia, ortopedia e pediatria; nos multi consultórios; nas multi salas; na regulação; na radiologia; e na sala verde (n 45, $18 \%$ ). Por último, definiu-se como nível 3 o trabalho de quem atua: na esterilização; nos consultórios bucomaxilo e otorrinolaringologia; na farmácia; na recepção e nas salas/consultório (n 90, 36 \%). (Tabela 3).

\section{Tabela 3 - Setor de alocação na Emergência - nível de responsabilidade}

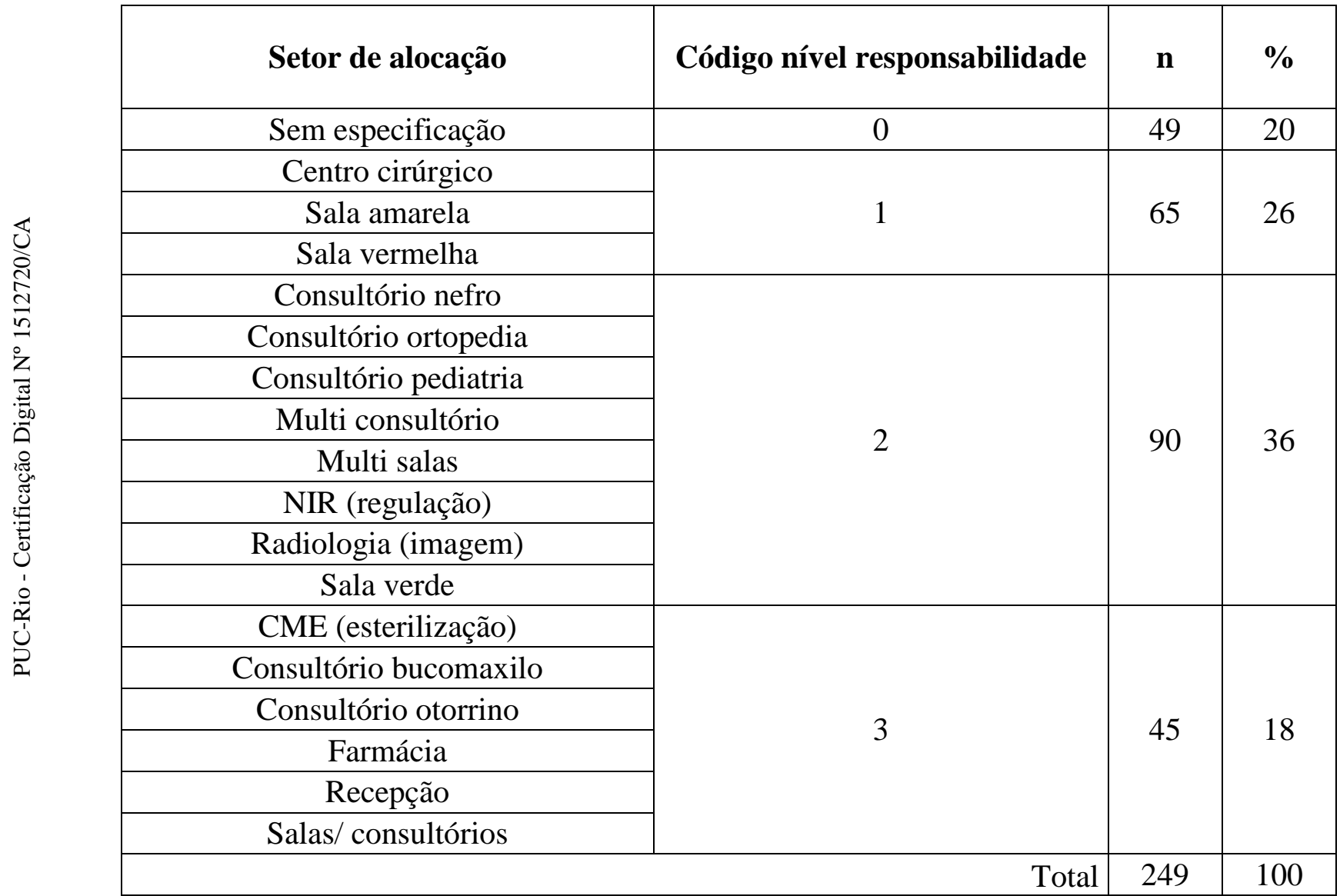

Na emergência os sujeitos da amostra são funcionários alocados nos turnos diurno, noturno e diurno/noturno e nas escalas: diarista, plantonista e dupla matrícula. Os códigos para análise foram definidos como dado nominal, sem critério de responsabilidade. A maior parte dos sujeitos atua no turno diurno (n 147, 59\%), seguidos por aqueles que trabalham em ambos os turnos (n 92, 37\%); e, no período noturno (n 10, 10\%) Quanto a escala de trabalho, os plantonistas 
foram maioria ( $\mathrm{n}$ 160, 64\%), seguidos pelos diaristas ( $\mathrm{n}$ 82, 33\%). O menor quantitativo foi o de sujeitos que atuam com dupla matrícula (n 7, 3\%). Foram 150 mulheres (60\%) e 99 homens (40\%). A faixa etária foi dividida em quatro grupos: 21-30 (n 78, 31\%); 31-40 (n 50, 20\%); 41-50 (n 55, 22\%); e 51 ou mais (n $66,27 \%$ ). (Tabela 4$)$

Tabela 4 - Turno, escala, sexo e faixa etária

\begin{tabular}{|c|c|c|c|}
\hline Turno & $\begin{array}{c}\text { Código } \\
\text { nominal }\end{array}$ & $\mathbf{n}$ & $\mathbf{\%}$ \\
\hline Diurno & 1 & 147 & 59 \\
\hline Noturno & 2 & 10 & 4 \\
\hline Diurno/noturno & 3 & 92 & 37 \\
\hline & Total & 249 & 100 \\
\hline Escala & $\begin{array}{c}\text { Código } \\
\text { nominal }\end{array}$ & $\mathbf{n}$ & $\mathbf{\%}$ \\
\hline Diarista & 1 & 82 & 33 \\
\hline Plantonista & 2 & 160 & 64 \\
\hline Dupla matricula & 3 & 7 & 3 \\
\hline \multicolumn{2}{|c|}{ Total } & 249 & 100 \\
\hline Sexo & $\begin{array}{c}\text { Código } \\
\text { nominal }\end{array}$ & $\mathbf{n}$ & $\mathbf{\%}$ \\
\hline Feminino & 1 & 150 & 60 \\
\hline Masculino & 2 & 99 & 40 \\
\hline \multicolumn{2}{|c|}{ Total } & 249 & 100 \\
\hline Faixa etária & $\begin{array}{c}\text { Código } \\
\text { nominal }\end{array}$ & $\mathbf{n}$ & $\%$ \\
\hline $21-30$ & 1 & 78 & 31 \\
\hline $31-40$ & 2 & 50 & 20 \\
\hline $41-50$ & 3 & 55 & 22 \\
\hline $51-m a i s$ & 4 & 66 & 27 \\
\hline \multicolumn{2}{|c|}{ Total } & 249 & 100 \\
\hline
\end{tabular}


Foi considerado o tempo no trabalho como uma variável para articulação. Neste aspecto, foram definidas quatro categorias divididas em duas faixas de 0,1 a 10 anos e de 11 ou mais. O tempo no trabalho considerou quatro características: o tempo na ocupação $(0,1-10$, n 137, 55\%; e, 11 - mais n, 112, 45\%); o tempo em emergência $(0,1-10$, n 163, 65\%; e, 11 - mais n, 86, 35\%); o tempo no Hospital Municipal Miguel Couto (0,1-10, n 144, 57\%; e, 11 - mais n, 105, 43\%); e, o tempo na emergência do Hospital Municipal Miguel Couto (0,1-10, n 169, 67\%; e, 11 - mais n, 80, 33\%). (Tabelas 5).

Tabela 5 - Tempo na ocupação, tempo na emergência, tempo no HMMC e tempo na emergência doHMMC

\begin{tabular}{|c|c|c|c|}
\hline $\begin{array}{l}\text { Tempo na } \\
\text { ocupação }\end{array}$ & $\begin{array}{c}\text { Código } \\
\text { nominal }\end{array}$ & $\mathbf{n}$ & $\%$ \\
\hline $0,1-10$ & 1 & 137 & 55 \\
\hline 11 - mais & 2 & 112 & 45 \\
\hline \multicolumn{2}{|r|}{ Total } & 249 & 100 \\
\hline $\begin{array}{c}\text { Tempo na } \\
\text { emergência }\end{array}$ & $\begin{array}{c}\text { Código } \\
\text { nominal }\end{array}$ & $\mathbf{n}$ & $\%$ \\
\hline $0,1-10$ & 1 & 163 & 65 \\
\hline 11 - mais & 2 & 86 & 35 \\
\hline \multicolumn{2}{|r|}{ Total } & 249 & 100 \\
\hline $\begin{array}{c}\text { Tempo no } \\
\text { HMMC }\end{array}$ & $\begin{array}{c}\text { Código } \\
\text { nominal } \\
\end{array}$ & $\mathbf{n}$ & $\%$ \\
\hline $0,1-10$ & 1 & 144 & 57 \\
\hline 11 - mais & 2 & 105 & 43 \\
\hline \multicolumn{2}{|r|}{ Total } & 249 & 100 \\
\hline $\begin{array}{l}\text { Tempo na } \\
\text { emergência } \\
\text { do HMMC }\end{array}$ & $\begin{array}{c}\text { Código } \\
\text { nominal }\end{array}$ & $\mathbf{n}$ & $\%$ \\
\hline $0,1-10$ & 1 & 169 & 67 \\
\hline 11 - mais & 2 & 80 & 33 \\
\hline \multicolumn{2}{|r|}{ Total } & 249 & 100 \\
\hline
\end{tabular}

No que se refere à moradia/núcleo familiar, foram categorizadas como: Sozinho (a) (n, 34, 14\%); com cônjuge (n, 37, 15\%); com cônjuge e/ou filhos (as) (n, 137, 55\%); e, com familiares e/ou amigos (as) (n, 41, 16\%); e, 2) 
responsabilidade financeira/núcleo familiar assim categorizadas: $\operatorname{Sim}(\mathrm{n}, 82$, 33\%); Não (n, 53, 21\%); e, Parcial (n, 114, 46\%). (Tabelas 6)

Tabela 6 - MORADIA/NÚCLEO FAMILIAR

\begin{tabular}{|c|c|c|c|}
\hline Moradia núcleo familiar & $\begin{array}{c}\text { Código } \\
\text { nominal }\end{array}$ & $\mathbf{n}$ & $\boldsymbol{\%}$ \\
\hline Sozinho(a) & 1 & 34 & 14 \\
\hline com cônjuge & 2 & 37 & 15 \\
\hline com cônjuges e/ou filhos(as) & 3 & 137 & 55 \\
\hline com familiares e/ou amigos(as) & 4 & 41 & 16 \\
\hline \multicolumn{2}{|c|}{ Total } & 249 & 100 \\
\hline $\begin{array}{c}\text { Responsabilidade financeira no } \\
\text { núcleo familiar }\end{array}$ & $\begin{array}{c}\text { Código } \\
\text { nominal }\end{array}$ & $\mathbf{n}$ & $\%$ \\
\hline sim & 1 & 82 & 33 \\
\hline não & 2 & 53 & 21 \\
\hline parcial & 3 & 114 & 46 \\
\hline \multicolumn{2}{|c|}{ Total } & 249 & 100 \\
\hline
\end{tabular}

\subsection{Instrumento}

Para investigar as representações sociais de sofrimento psíquico em relação ao trabalho, a coleta de dados foi realizada com o Inventário de avaliação de penosidade, protocolo de entrevista estruturada e direcionada, tendo como indicadores, as três dimensões extraídas da abordagem da Psicodinâmica do Trabalho (DEJOURS, 1993, 1994, 1998, 2000 e SATO, 1999), familiaridade, poder e limite subjetivo, definidas em quatro níveis de representações (MOSCOVICI, 1978, 1990, 2003; DOISE, 2002; ALMEIDA, 2009), intraindividual, interpessoal, intergrupal e societal, gerando os 12 itens para coletar o discurso dos sujeitos, conforme descrito na Figura 2. 


\section{Figura 2 - Protocolo de Entrevista sobre Sofrimento Psíquico no trabalho}

\begin{tabular}{|c|c|c|}
\hline Dimensão & Nível & Item \\
\hline \multirow[t]{4}{*}{ Familiaridade } & Intraindividual & $\begin{array}{l}\text { 1. O que significa, para você, ser [nome da ocupação] com atuação no } \\
\text { (a) [local de trabalho]? }\end{array}$ \\
\hline & Interpessoal & 2. Como é seu dia a dia com os colegas e/ou clientes? \\
\hline & Intergrupal & $\begin{array}{l}\text { 3. Como você percebe o seu trabalho quando comparado aos exercidos } \\
\text { por outros grupos de pessoas? }\end{array}$ \\
\hline & Societal & 4. O que a sociedade pensa sobre profissionais de sua área de atuação? \\
\hline \multirow[t]{4}{*}{ Poder } & Intraindividual & $\begin{array}{l}\text { 5. Como você percebe sua autonomia na realização de suas atividades } \\
\text { de trabalho? }\end{array}$ \\
\hline & Interpessoal & $\begin{array}{l}\text { 6. Relate uma situação em que você precisou intervir diante de uma } \\
\text { situação com colegas e/ou clientes. }\end{array}$ \\
\hline & Intergrupal & 7. Como é seu trabalho quando outros grupos também participam dele? \\
\hline & Societal & $\begin{array}{l}\text { 8. Como é a valorização do profissional de [nome da ocupação] com } \\
\text { atuação no (a) [local de trabalho]? }\end{array}$ \\
\hline \multirow{4}{*}{$\begin{array}{l}\text { Limite } \\
\text { Subjetivo }\end{array}$} & Intraindividual & 9. Comente sobre seu horário de expediente. \\
\hline & Interpessoal & $\begin{array}{l}\text { 10. Relate uma situação que ocorreu com você e seus colegas e/ou } \\
\text { clientes. }\end{array}$ \\
\hline & Intergrupal & $\begin{array}{l}\text { 11. Como é sua comunicação com seus familiares e amigos quando } \\
\text { está no turno de trabalho? }\end{array}$ \\
\hline & Societal & $\begin{array}{l}\text { 12. Qual a ideia que a sociedade tem sobre as situações que envolvem a } \\
\text { sua área de atuação? }\end{array}$ \\
\hline
\end{tabular}

\subsection{Cuidados Éticos}

A realização de entrevista foi por livre escolha e consentimento de acordo com o Termo de Consentimento Livre e Esclarecido -TCLE. Foram realizadas por estagiários devidamente treinados e supervisionados. Inicialmente, o estagiário apresentou os objetivos do trabalho aos funcionários e entregou o termo de consentimento livre e esclarecido, aprovado pelo Comitê de Ética em pesquisa da Secretaria Municipal de Saúde e Defesa Civil do município do Rio de Janeiro, que foi assinado por cada interessado em participar da pesquisa conforme apresentado no anexo 1 


\subsection{Análises estatísticas}

Quanto ao segundo e terceiro objetivos desta tese de doutorado, qual seja, verificar a qualidade psicométrica do instrumento e investigar as representações sociais de sofrimento psíquico em relação ao trabalho, foi avaliada a fidedignidade e validade de constructo do instrumento.

\subsubsection{Análises descritivas}

O protocolo de entrevista, sistematizado em planilha (Excel), foi analisado com cruzamentos realizados por gráficos dinâmicos. Os resultados são apresentados por dimensões (familiaridade, poder e limite-subjetivo) e níveis (intraindividual, interpessoal, intergrupal e societal).

Os critérios para transformar em dados quantitativos as respostas a cada item avaliado qualitativamente pela entrevista são: 0 - NÃO há aspecto negativo; 1 - há aspecto negativo de baixa intensidade acompanhado de aspecto positivo; 2 - há aspecto negativo de alta intensidade com aspecto positivo associado; 3 - há aspecto negativo de baixa intensidade sem aspecto positivo associado; 4 - há aspecto negativo de alta intensidade sem aspecto positivo associado; e, 5 - há aspecto negativo de alta intensidade reforçado por superlativos, repetições e emoções não verbais associadas.

No que se refere à investigação das representações sociais de sofrimento psíquico em relação ao trabalho, seguem-se a descrição dos resultados, apresentando-os por gráficos dinâmicos oriundo do software Excel. Esta opção justifica-se por considerar a facilidade de manejo do software, com fins de diagnóstico, a partir de banco de dados criado com a transformação da análise dos discursos das respostas dos sujeitos em relação aos 12 itens do instrumento.

Considerando todas as ocupações a penosidade apresentou uma média de 1,5. Isto significa que, de forma geral, os funcionários que atuam na emergência do Hospital Municipal Miguel Couto - HMMC tem um sofrimento psíquico, que embora tenha intensidade considerável, tem sido amenizado por algum tipo de estratégia defensiva que, entretanto, entretanto não tem sido suficiente. (Gráfico 3) 
GRÁFICO 3 - Penosidade funcionários do Hospital Municipal Miguel Couto - Emergência - total

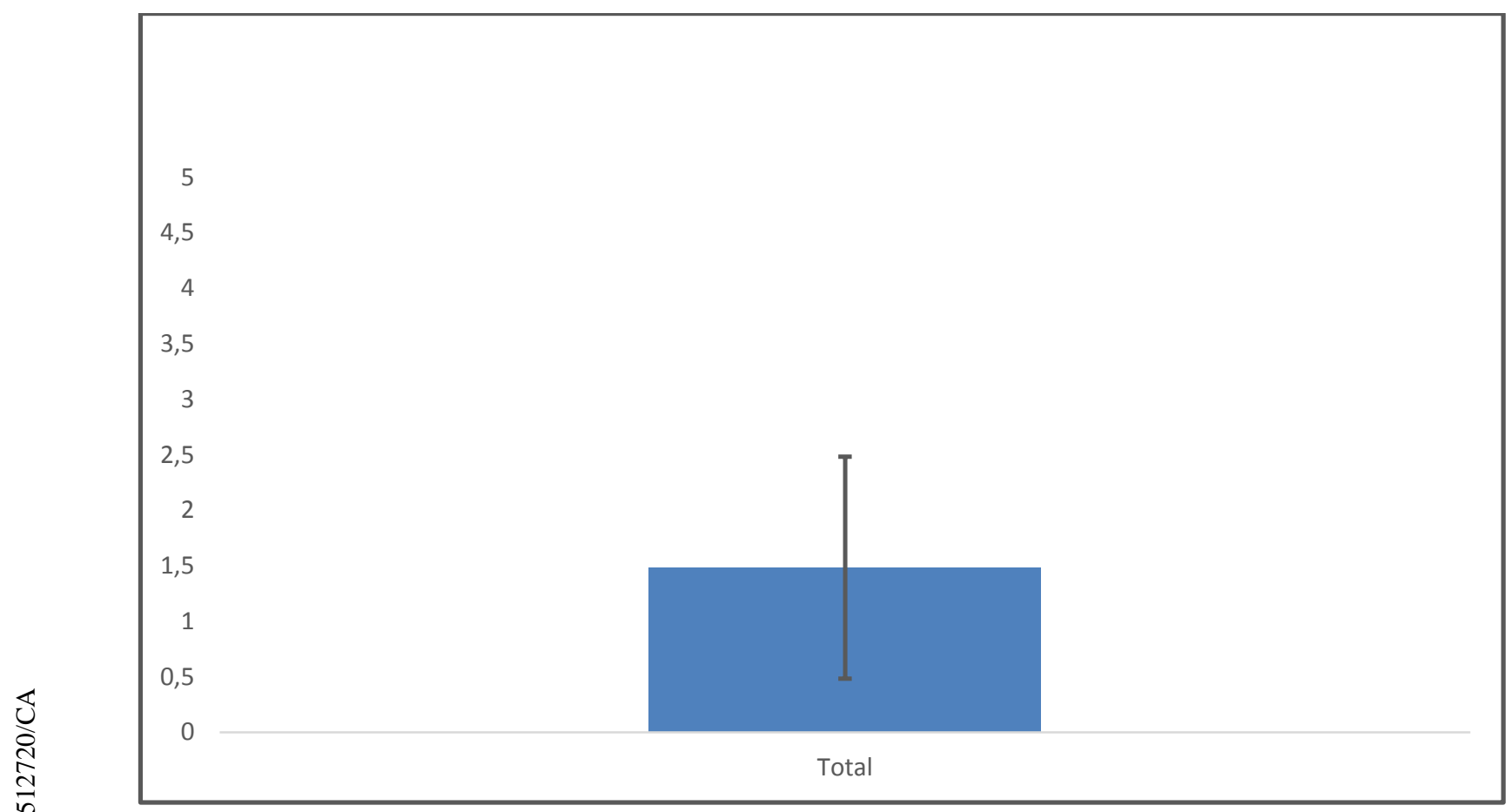

Considerando todas as ocupações, é possível verificar em quais dimensões este sofrimento ocorre. Embora apresente diferença pequena entre as dimensões, Limite Subjetivo (penosidade 1,6) e Poder (penosidade 1,5) apresentam-se com índices mais elevados que Familiaridade (1,3). (Gráfico 4) 


\section{GRÁFICO 4 - Penosidade por dimensão}

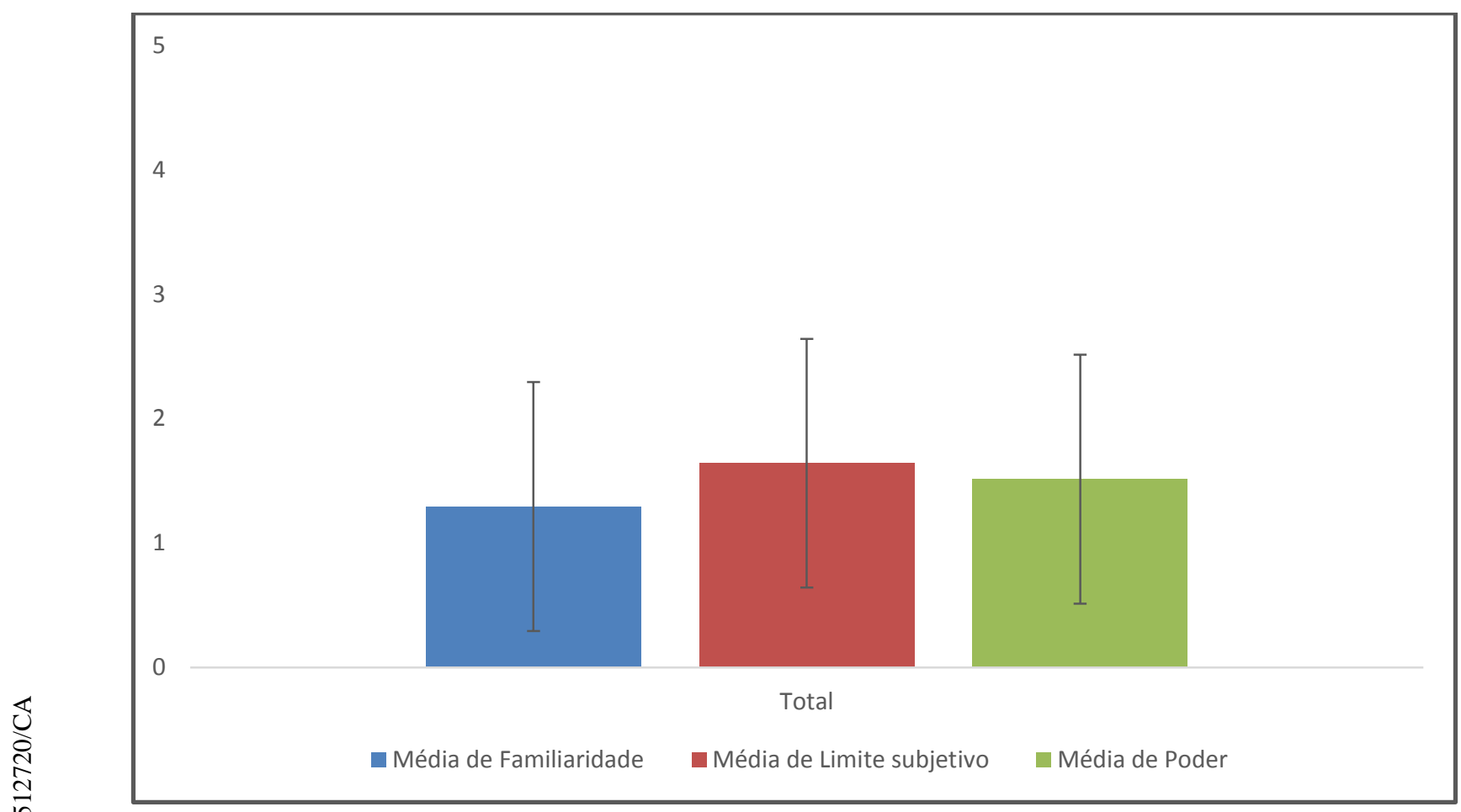

Ainda considerando todas as ocupações, é possível verificar que o nível Societal (penosidade 2,6) se distingue dos demais. Segue-se o nível Interpessoal (penosidade 1,4) e, na sequência os níveis Intraindividual (penosidade 1,0) e Intergrupal (penosidade 0,9). O nível Interpessoal e o nível Intraindividual, embora apresentem sofrimento, estão amenizados por estratégias de defesa. (Gráfico 5) 


\section{Grafico 5 - Penosidade por nível de representação}

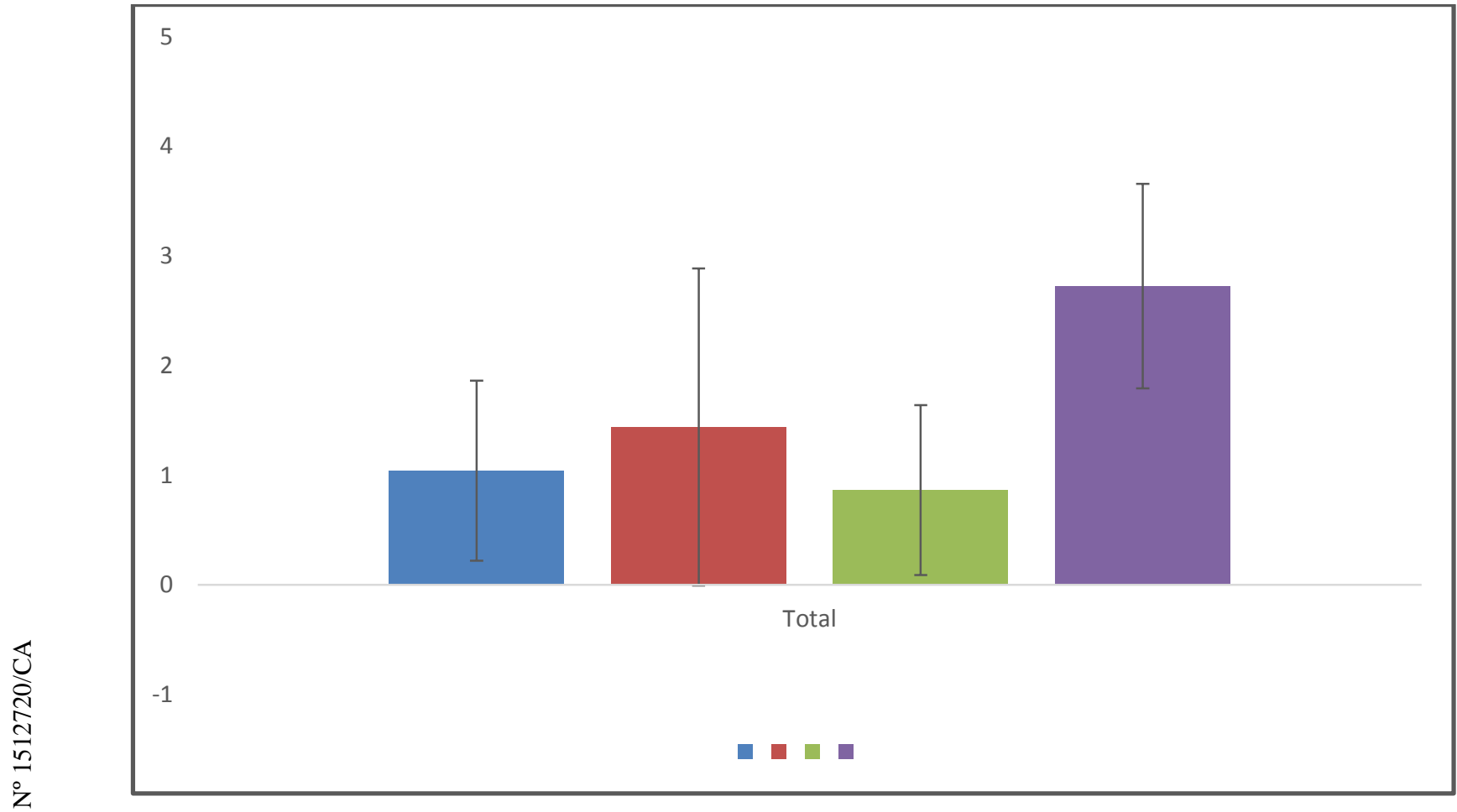

Ao associar dimensões e níveis de análise, verifica-se que o nível Societal, apresenta-se com sofrimento psíquico de alta intensidade (Limite Subjetivo penosidade 2,8; Familiaridade penosidade 2,5; Poder penosidade 2,4). (Gráfico 6) 


\section{Grafico 6 - Penosidade por dimensão/nível de representação}

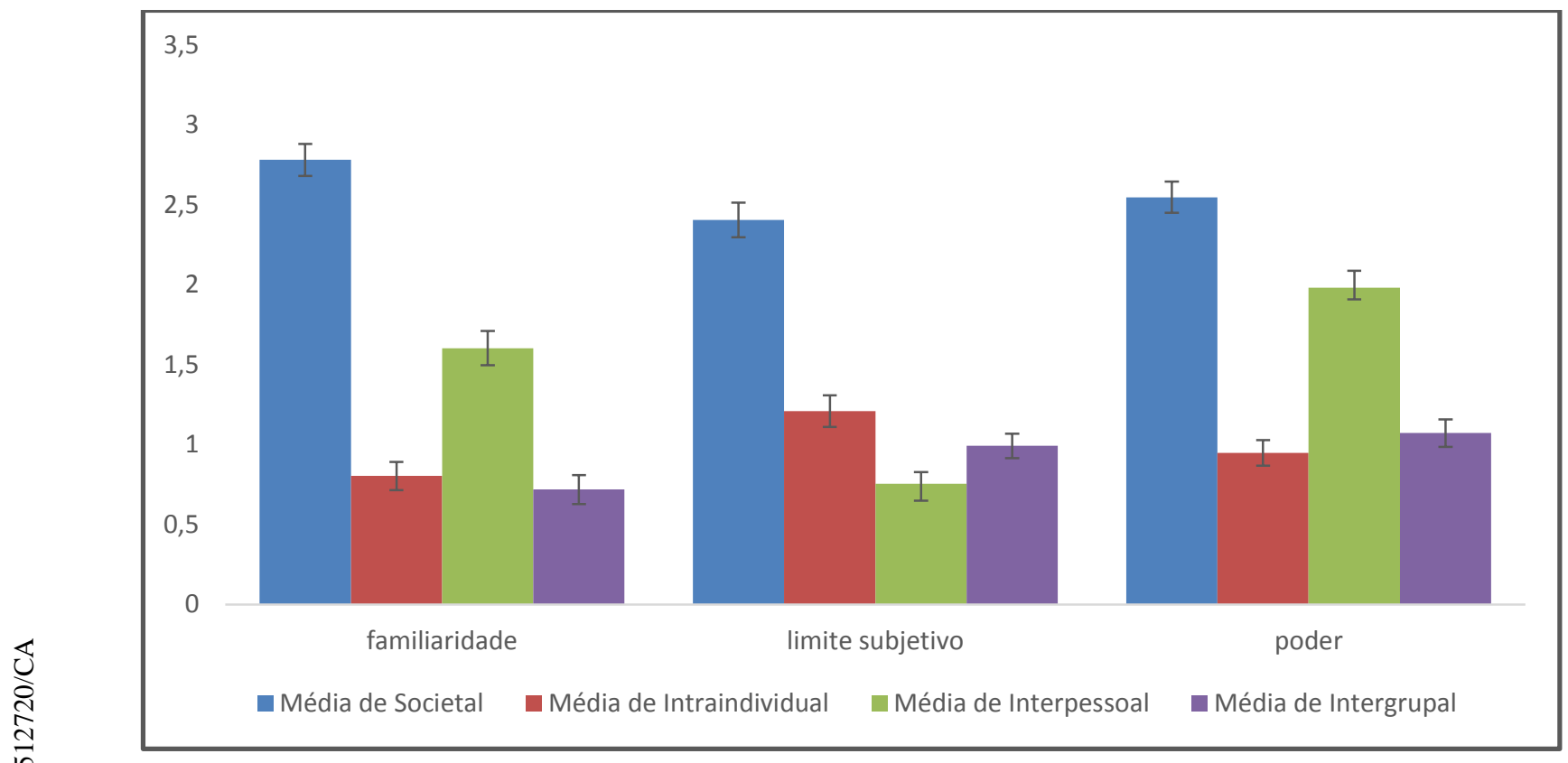

Quando os resultados são demonstrados pelo nível de responsabilidade das ocupações, verifica-se que os maiores níveis de responsabilidade, apresentaram penosidade de intensidade maior que 1,5.(médio alto 1,9; médio 1,7; máximo 1,6; altíssimo e alto 1,5). As ocupações, de forma geral, com nível responsabilidade menores apresentaram, também, menores índices de penosidade, embora significativos. (médio baixo 1,2; baixo e mínimo 1,1). (Gráfico 7) 


\section{Grafico 7 - Penosidade Responsabilidade da ocupação GG/CBO -} Total

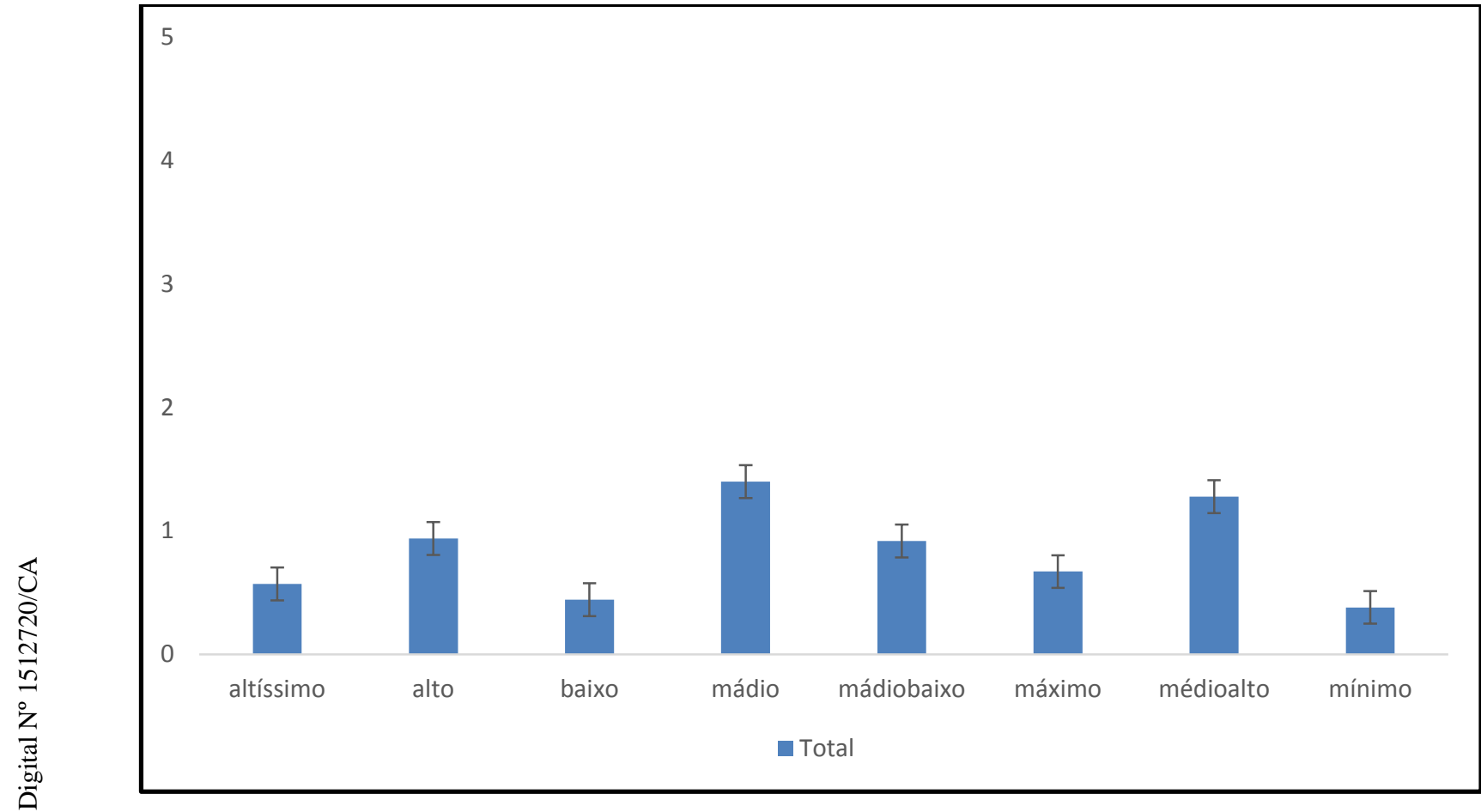

Ao desdobrar os indicadores por ocupação do Grande Grupo 2 do CBO, considerando a ocupação Médico, que está categorizada como nível máximo de responsabilidade, verifica-se que no nível de representação Societal há penosidade de alta intensidade nas três dimensões (Limite Subjetivo 3,0; Familiaridade 2,8; Poder 2,7). No que se refere ao nível Interpessoal, as dimensões Poder e Limite Subjetivo, também apontam para resultados significativos em termos de sofrimento psíquico (Poder 3,0; Limite Subjetivo 1,7) (Gráfico 8) 


\section{Grafico 8 - Penosidade Responsabilidade da ocupação GG2/CBO máximo (médico)}

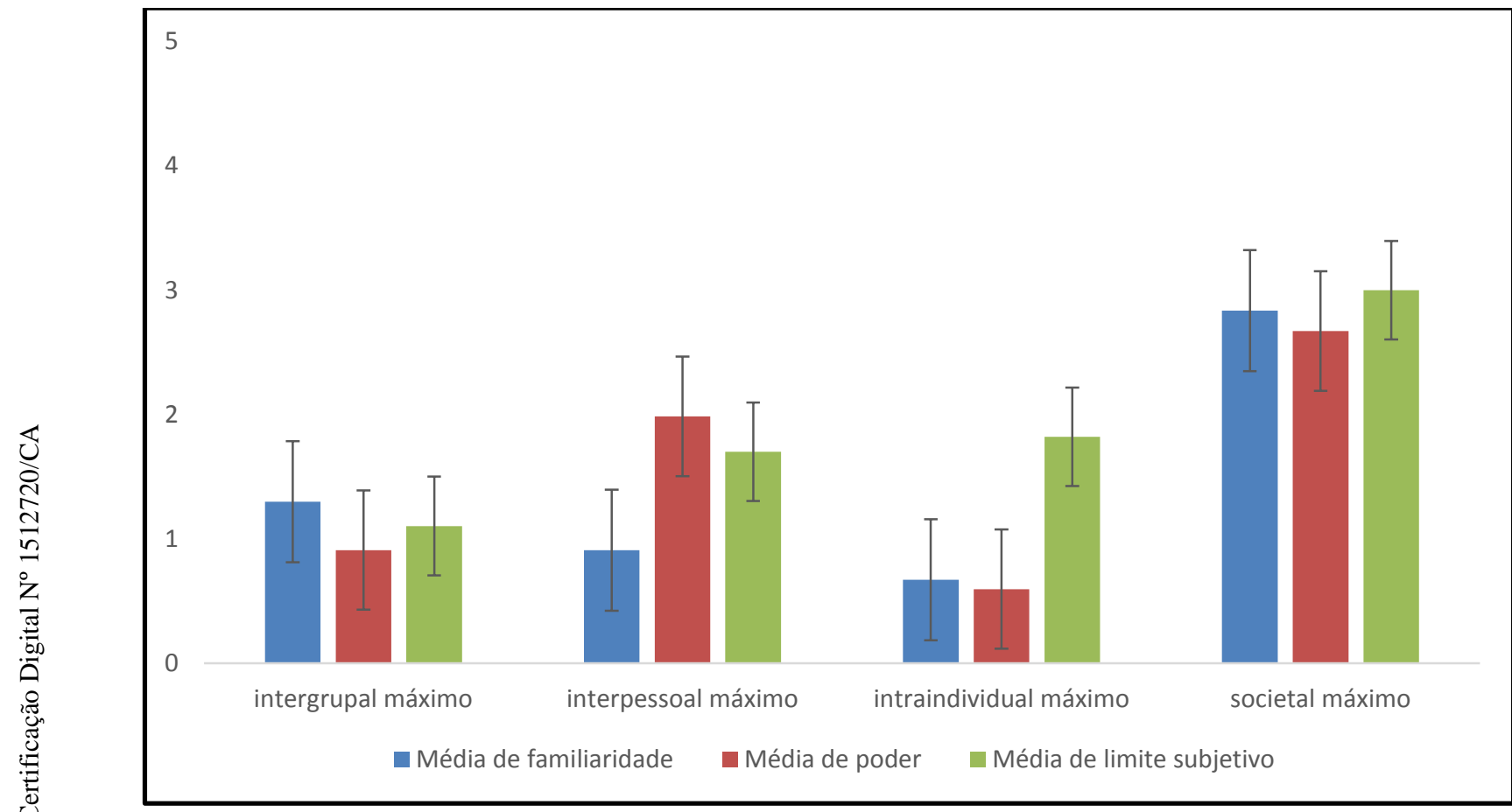

$\mathrm{Na}$ ocupação Enfermeiro, que está categorizada como nível altíssimo de responsabilidade na ocupação do Grande Grupo 2 do $\mathrm{CBO}$, verifica-se proximidade de resultados. O nível de representação Societal apresenta penosidade de alta intensidade nas três dimensões (Limite Subjetivo 3,3; Familiaridade 2,5; Poder 2,2). No que se refere ao nível Interpessoal, as dimensões Poder e Limite Subjetivo, também apontam para resultados significativos em termos de sofrimento psíquico (Poder 2,5; Limite Subjetivo 1,6). (Gráfico 9) 


\section{Grafico 9 - Penosidade Responsabilidade da ocupação GG2/CBO altíssimo (enfermeiro)}

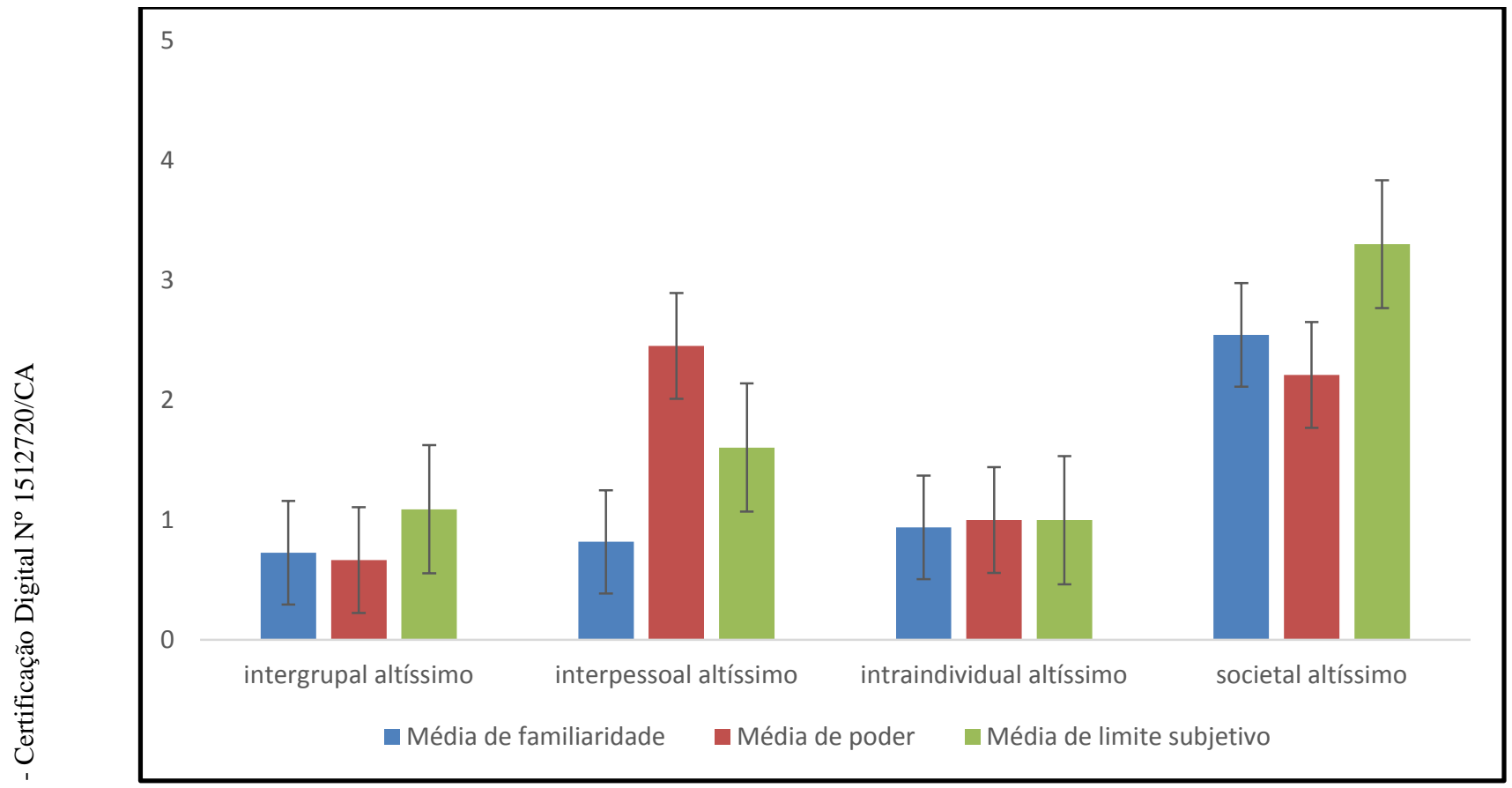

Nas demais ocupações no GG2 do CBO, Assistente Social, Dentista, Fonoaudiólogo, Nutricionista, Psicólogo, categorizadas como nível alto de responsabilidade, novamente verifica-se semelhança de resultados, no que tange ao nível de representação Societal apresenta penosidade de alta intensidade nas três dimensões (Limite Subjetivo 2,7; Poder 2,3; Familiaridade 2,0). Entretanto, a penosidade na dimensão Limite Subjetivo está distribuída quanto aos resultados nos níveis de representação Intergrupal (penosidade 1,6) e Intraindividual (penosidade 1,6). No que se refere ao nível Intergrupal, a dimensão Poder, 
também aponta para resultado significativo em termos de sofrimento psíquico (Poder 1,7;). (Gráfico 10)

\section{Grafico 10 - Penosidade Responsabilidade da ocupação GG2/CBO alto (Assistente Social, Dentista, Fonoaudiólogo, Nutricionista, Psicólogo)}

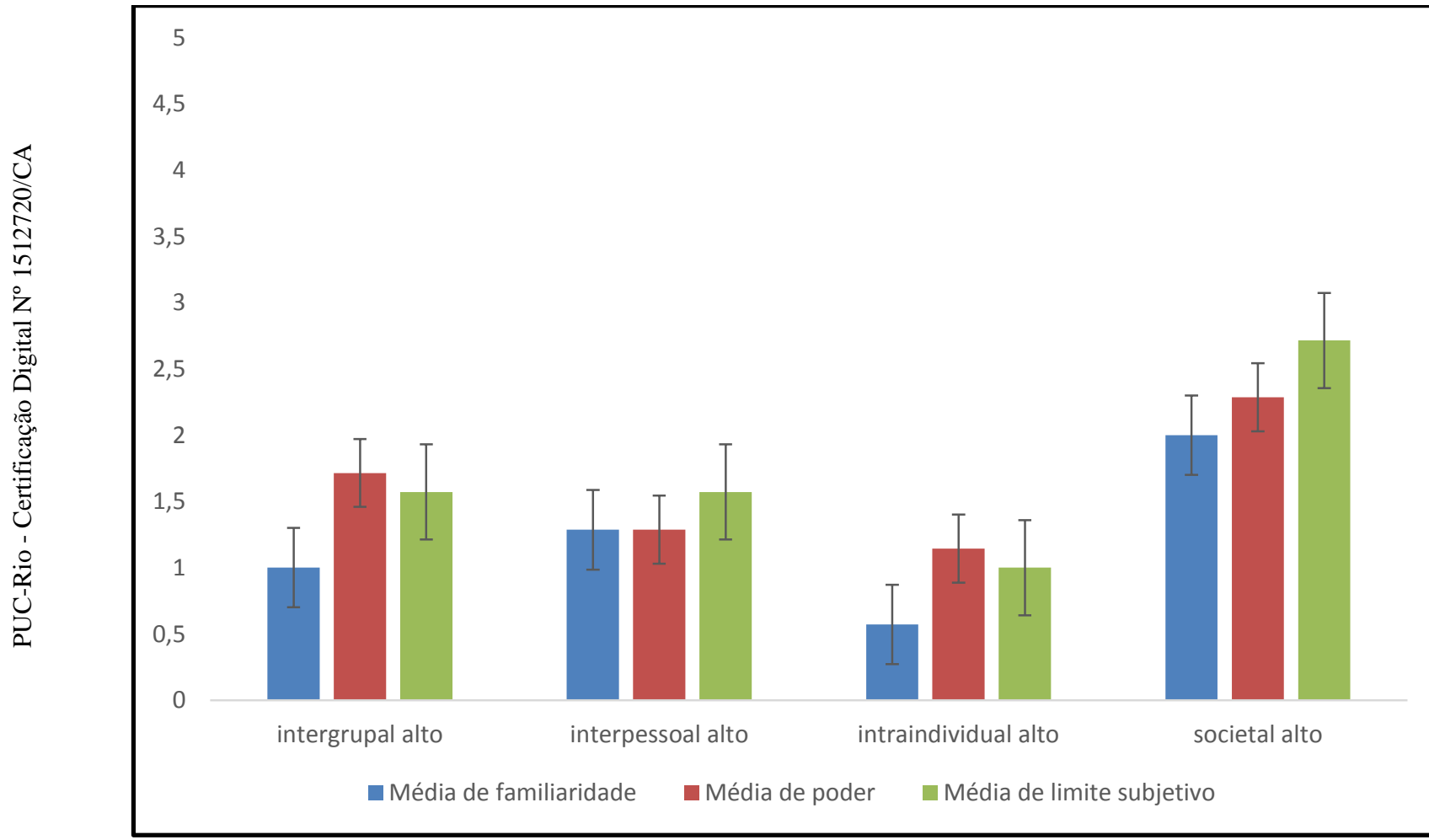

O Gráfico 11 mostra que a penosidade de Técnico de Enfermagem, incluída com grau médio/alto de responsabilidade no GG3 do CBO, apresenta sofrimento psíquico de alta intensidade, nos quatro níveis de representação (Intergrupal/Familiaridade penosidade 2,0; Interpessoal/Poder penosidade 2,3; Interpessoal/Limite Subjetivo penosidade 2,0; Intraindividual/Poder penosidade 
1,6; Intraindividual/Limite Subjetivo penosidade 1,5 Limite Subjetivo 3,1); Poder $(2,9)$ e Familiaridade $(2,9)$.

Grafico 11 - Penosidade Responsabilidade da ocupação GG3/CBO médio/alto (Técnico de enfermagem)

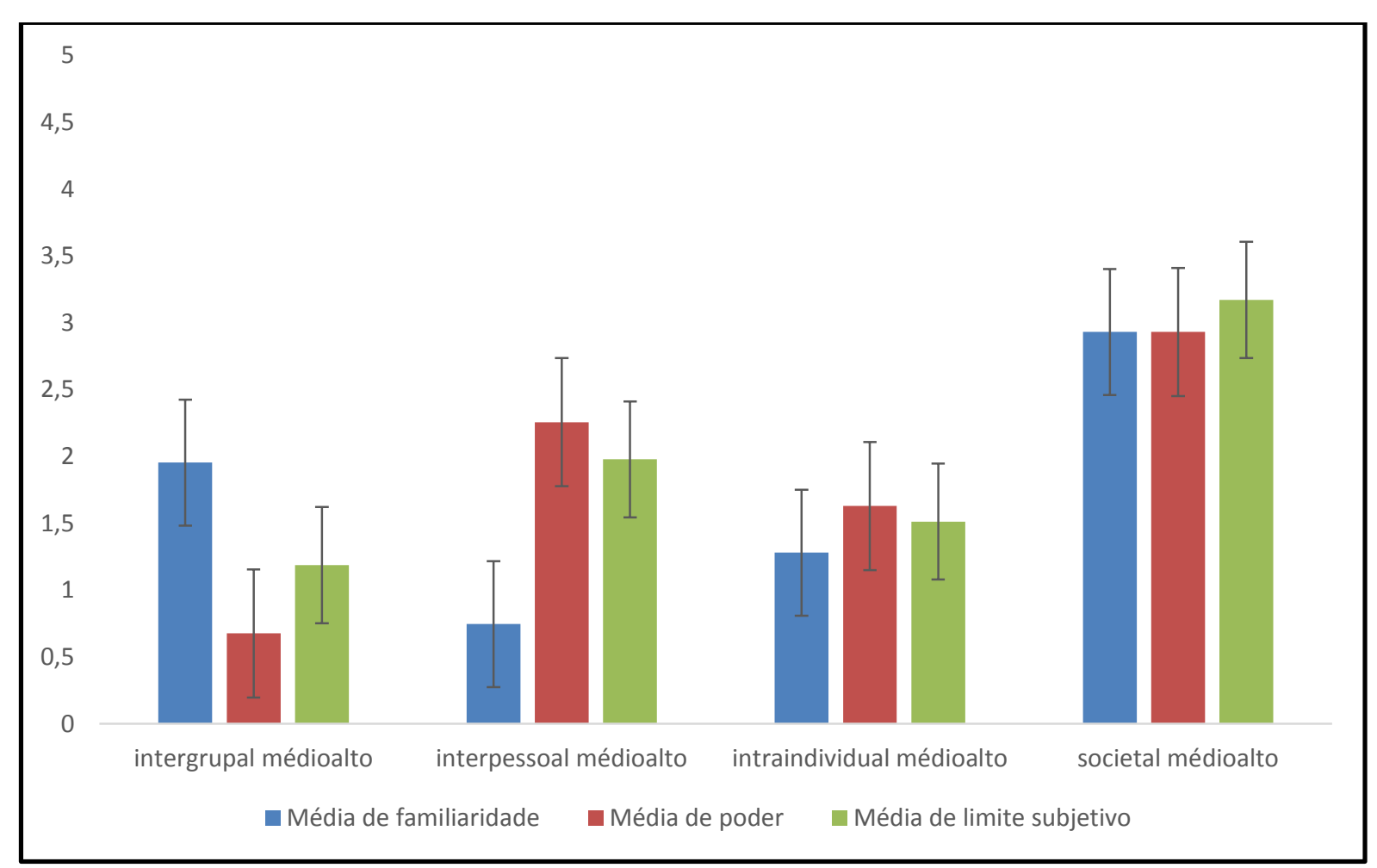

Nas demais ocupações no GG3 do CBO, Instrumentista cirúrgico, Técnico gessista, Técnico em radiologia, Secretária, categorizadas como nível médio de 
responsabilidade, os resultados também se assemelham em níveis de representação. Quanto ao nível de representação Societal apresentam penosidade de alta intensidade nas três dimensões (Familiaridade 3,4; Limite Subjetivo 3,3; Poder 2,2). Nas dimensões Familiaridade e Limite Subjetivo (Societal/Familiaridade penosidade 3,4; Societal/Limite Subjetivo penosidade 3,3). (Gráfico 12)

Grafico 12 - Penosidade Responsabilidade da ocupação GG3/CBO médio (Instrumentista cirúrgico, Técnico gessista, Técnico em radiologia, Secretária)

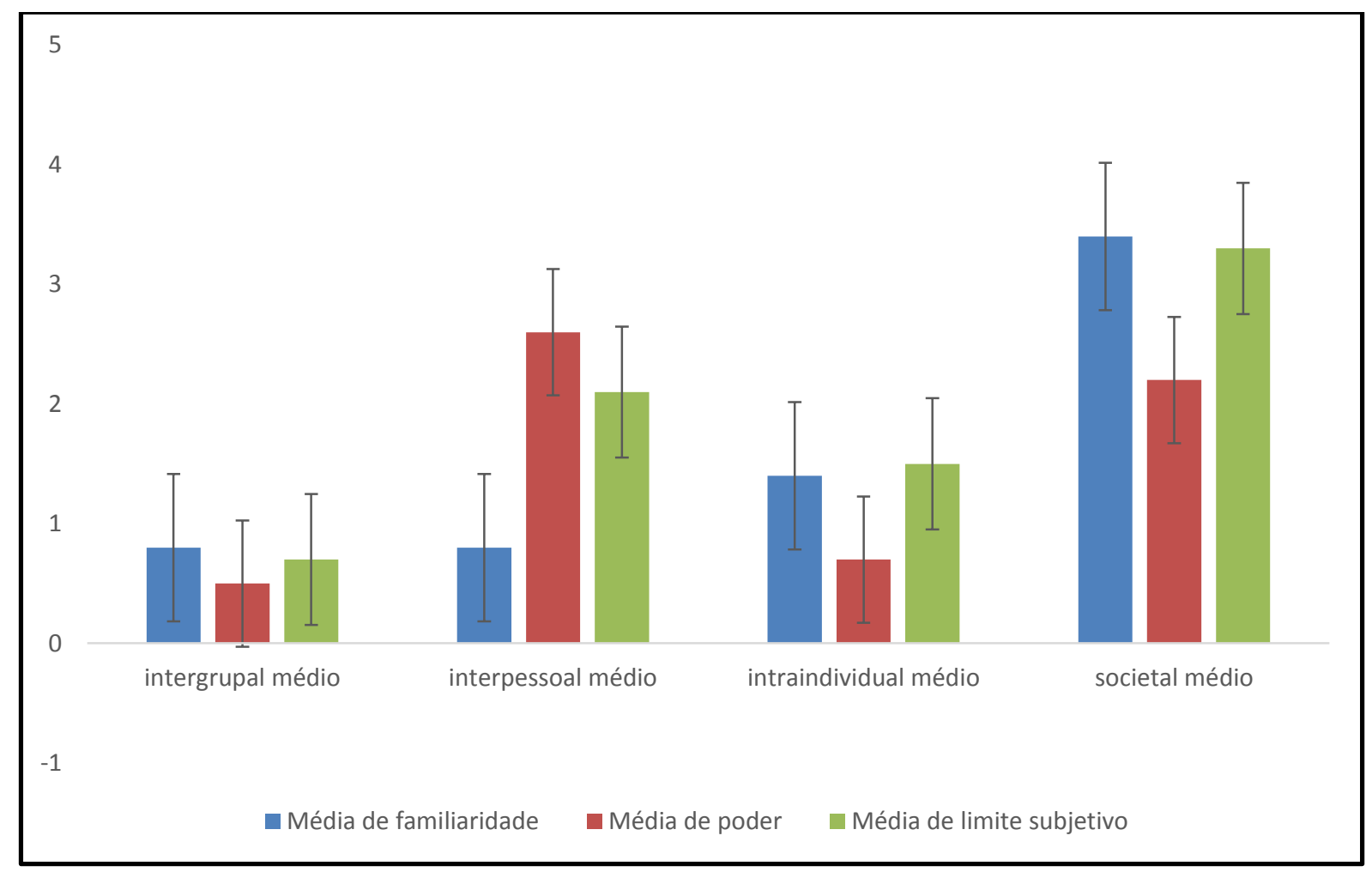


Nas ocupações dos grandes grupos - GG4 (nível de responsabilidade médio/baixo), Auxiliar administrativo e recepcionista; GG5 (nível de responsabilidade baixo), Auxiliar de serviços Gerais, Copeiro, Gari, Maqueiro, Segurança, Vigilante; e das ocupações sem código no CBO, (nível de responsabilidade mínimo), Acadêmico e Estagiário; o nível Societal também aparece como importante nos resultados. (GG4 - Familiaridade, penosidade 2,4; Limite Subjetivo, penosidade, 2,3; Poder, penosidade 2,0; GG5 - Poder, penosidade 2,1; Familiaridade, penosidade, 2,0; Limite Subjetivo, penosidade 1,9; Sem código CBO - Limite Subjetivo, penosidade 2,7; Familiaridade, penosidade, 2,0; Poder, penosidade 1,9). Também aparece como importante os indicadores no nível de representação Interpessoal nos GGs 4 e 5, (GG4 - Poder, penosidade 1,8; Limite Subjetivo, penosidade, 1,7; GG5 - Poder, penosidade 1,8). (Gráficos 13, 14 e 15)

\section{Grafico 13 - Penosidade Responsabilidade da ocupação GG4/CBO médio/baixo (Auxiliar administrativo e recepcionista)}

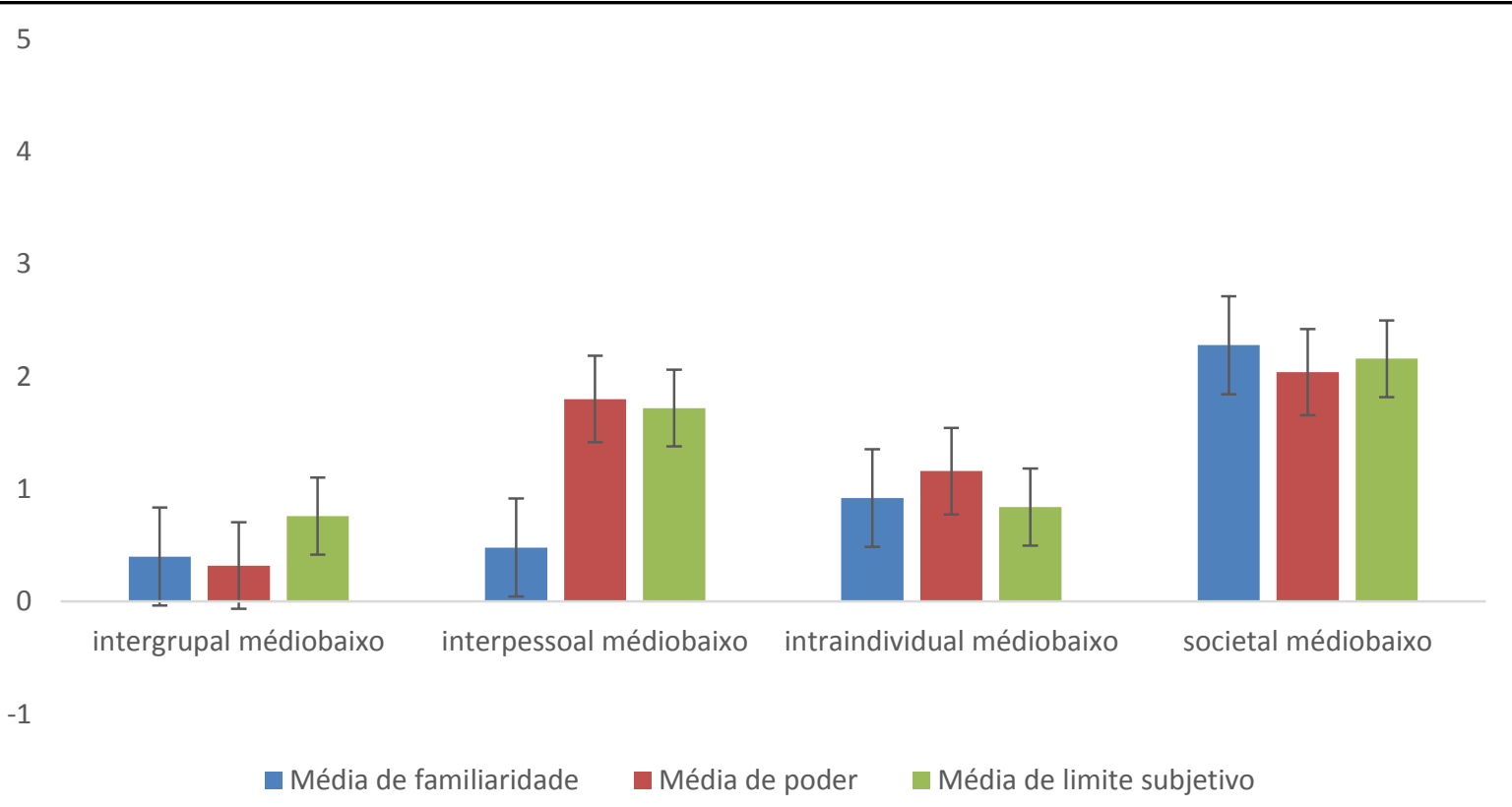


Grafico 14 - Penosidade Responsabilidade da ocupação GG5/CBO baixo (Auxiliar de serviços Gerais, Copeiro, Gari, Maqueiro, Segurança, Vigilante)

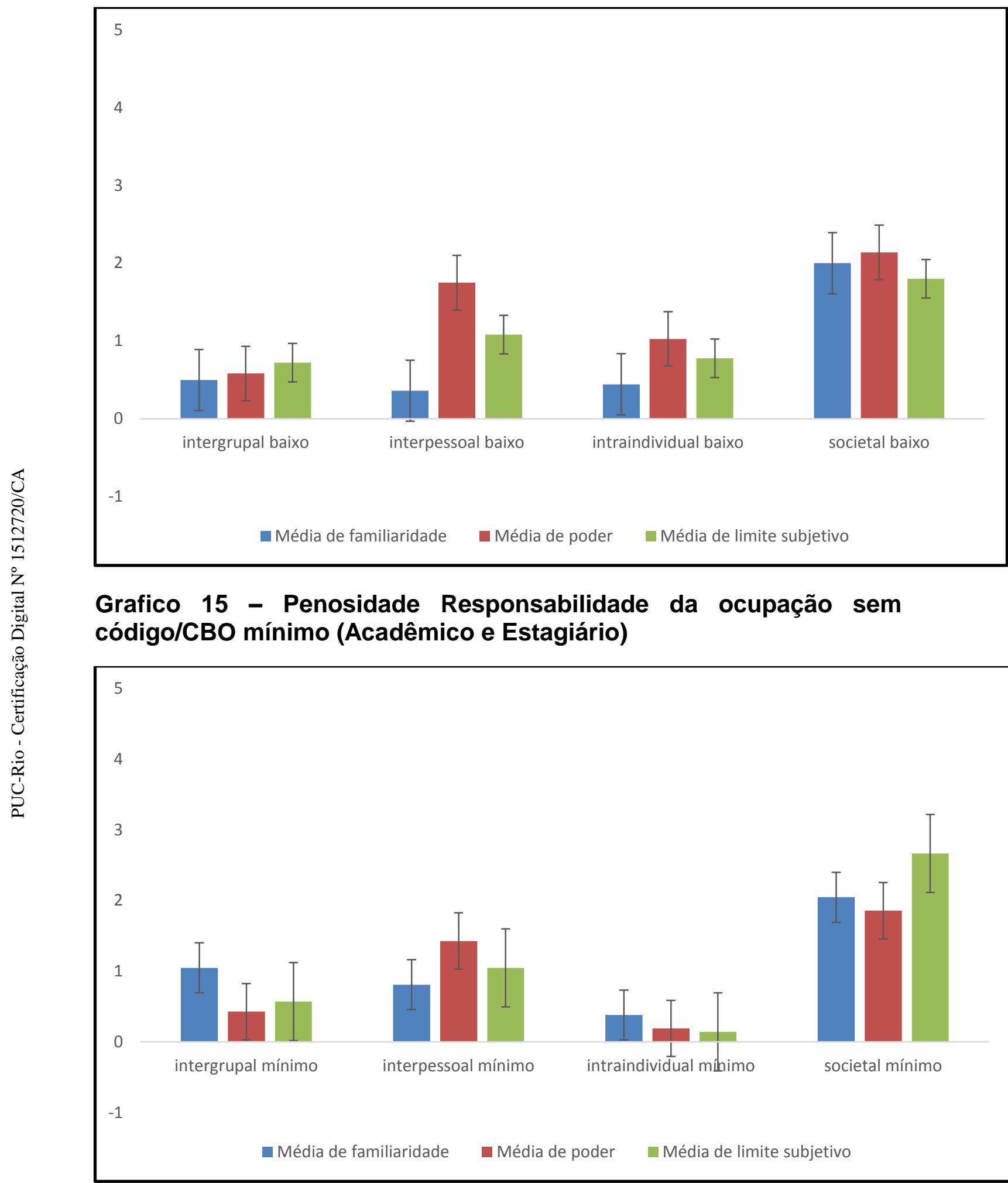


Quanto ao setor de alocação, os dados foram coletados em quatro níveis de responsabilidade: alta (centro cirúrgico; na sala amarela e na sala vermelha); média (consultórios de nefrologia, ortopedia e pediatria; nos multi consultórios; nas multi salas; na regulação; na radiologia; e na sala verde); baixa (esterilização; nos consultórios bucomaxilo e otorrinolaringologia; na farmácia; na recepção e nas salas/consultório) e sem especificação (atuam em todos os setores). O gráfico 16 mostra que, neste aspecto, a penosidade aparece de forma distribuída entre os níveis de responsabilidade, mas que nos níveis baixo e sem especificação a penosidade não está acompanhada de estratégias defensivas eficazes (Baixa: penosidade 1,5 e sem especificação: penosidade 1,5)

\section{Grafico 16 - Penosidade Responsabilidade do setor de alocação - Total}

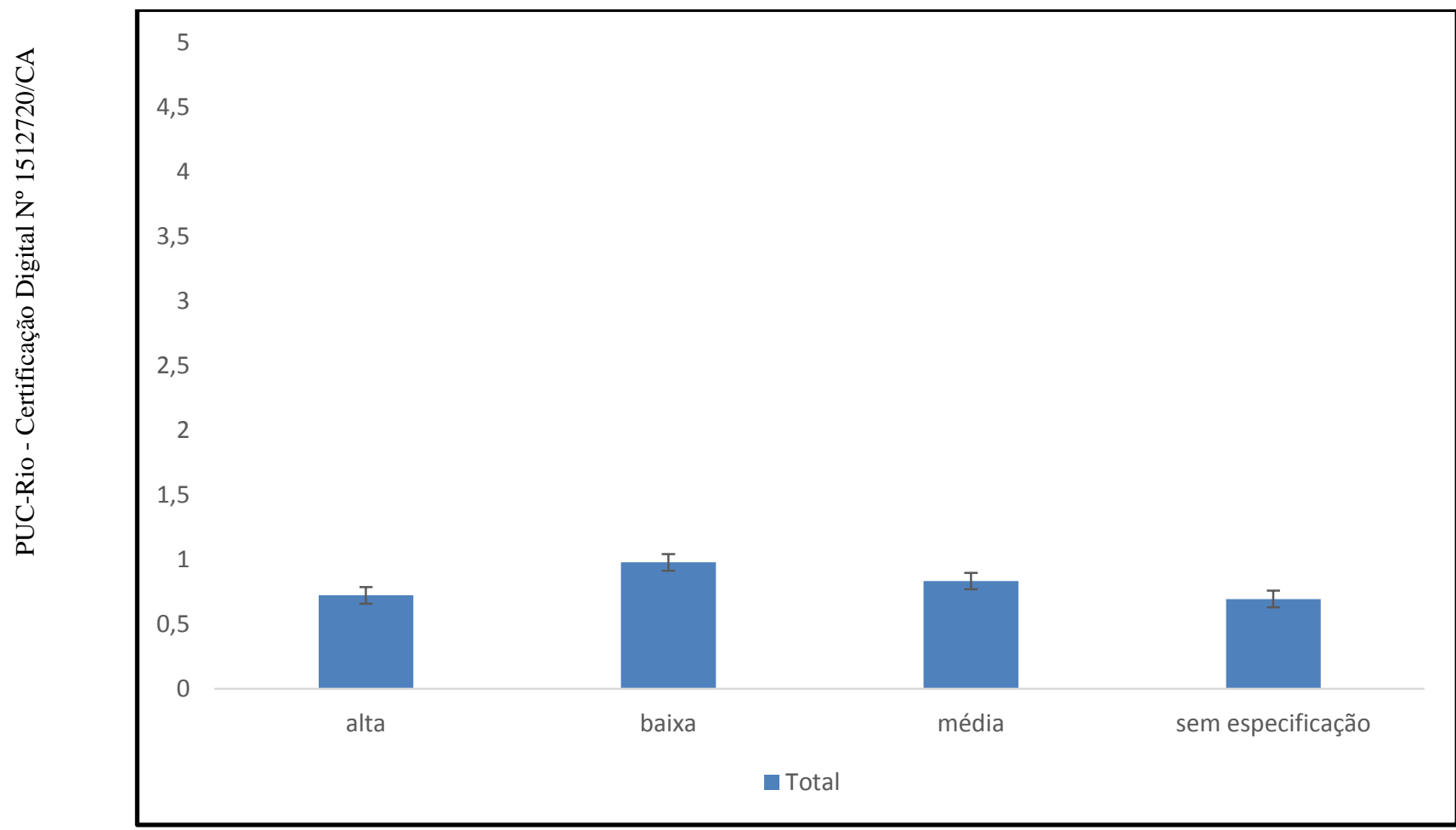

Quando desdobramos os resultados para analisar o nível alto no que se refere aos setores, o mesmo fenômeno se repete: os indicadores de maior intensidade estão nos níveis de representação Societal (Familiaridade e Limite 
Subjetivo penosidade 2,6; e Poder penosidade 2,3); e, Interpessoal (Poder penosidade 2,1; e Limite Subjetivo 1,7). (Gráfico 17)

Grafico 17 - Penosidade Responsabilidade do setor de alocação Alta (Centro cirúrgico, Sala vermelha e Sala amarela)

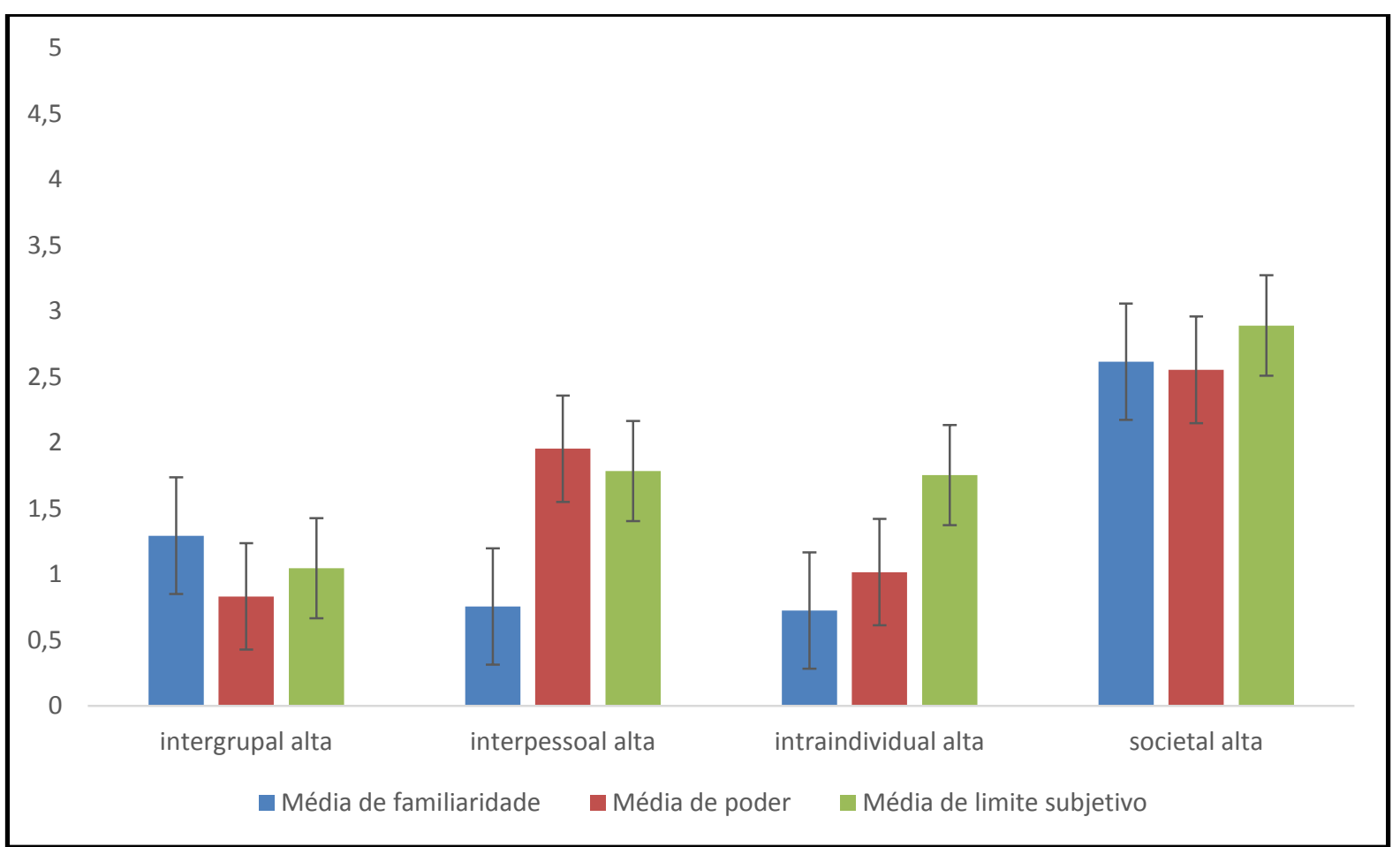


A mesma situação aparece no desdobramento do nível médio e também no nível baixo, quanto ao setor de alocação, onde os indicadores de maior intensidade estão nos níveis de representação Societal (Médio Limite Subjetivo penosidade 2,6; Médio Familiaridade penosidade 2,4 e Médio Poder penosidade 2,3; e Baixo Limite Subjetivo penosidade 2,9; Baixo Familiaridade penosidade 2,6 e Baixo Poder penosidade 2,6); e, Interpessoal (Médio Poder penosidade 2,0; e Médio Limite Subjetivo 1,5; Baixo Poder penosidade 2,0; e Baixo Limite Subjetivo 1,8). (Gráficos 18 e 19).

Grafico 18 - Penosidade Responsabilidade do setor de alocação Média (Consultório nefrologia, Consultório ortopedia, Consultório pediatria, Multi consultório, Multi salas, Regulação, Radiologia e Sala verde)

1

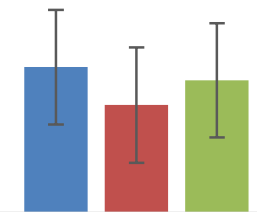

intergrupal média
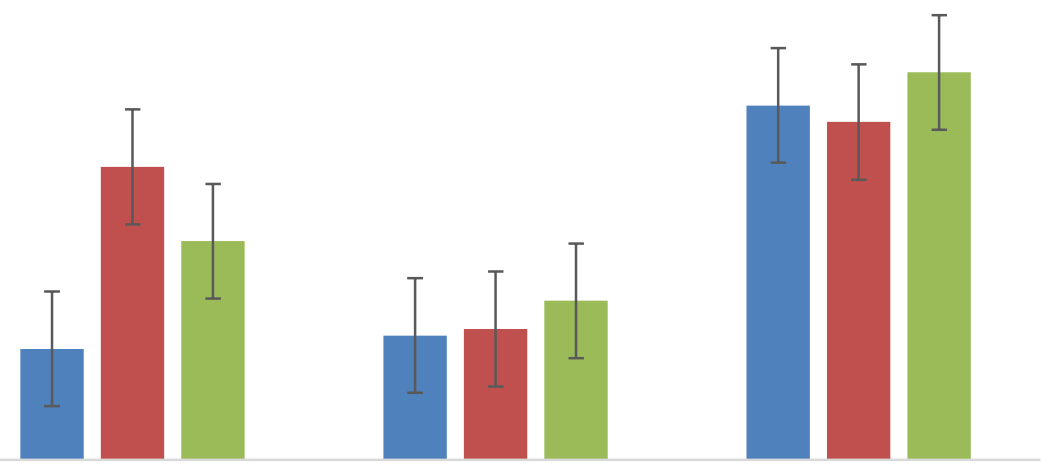

interpessoal média

intraindividual média

societal média 
Grafico 19 - Penosidade Responsabilidade do setor de alocação Baixa (Esterilização, Consultório bucomaxilo, Consultório otorrinolaringologia, Farmácia, Recepção, Salas/ consultórios)

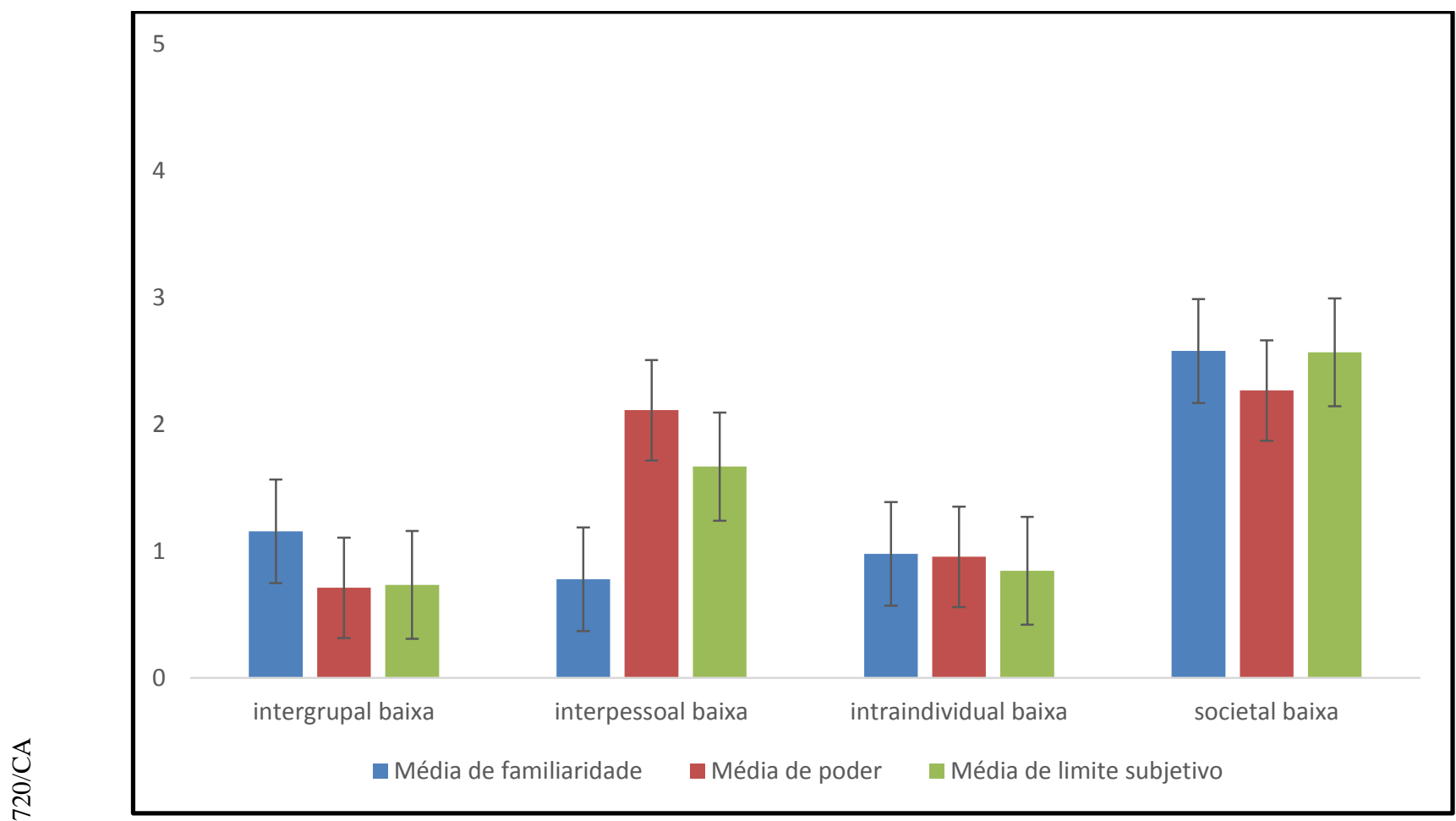

No que se refere aos turnos de trabalho, divididos em diurno, noturno e diurno/noturno, os resultados demonstram que o sofrimento psíquico afeta com maior intensidade aqueles sujeitos que atuam nos turnos noturno (penosidade 1,9) e diurno/noturno (1,6). (Gráfico 20) 


\section{Grafico 20 - Penosidade turno - Total}

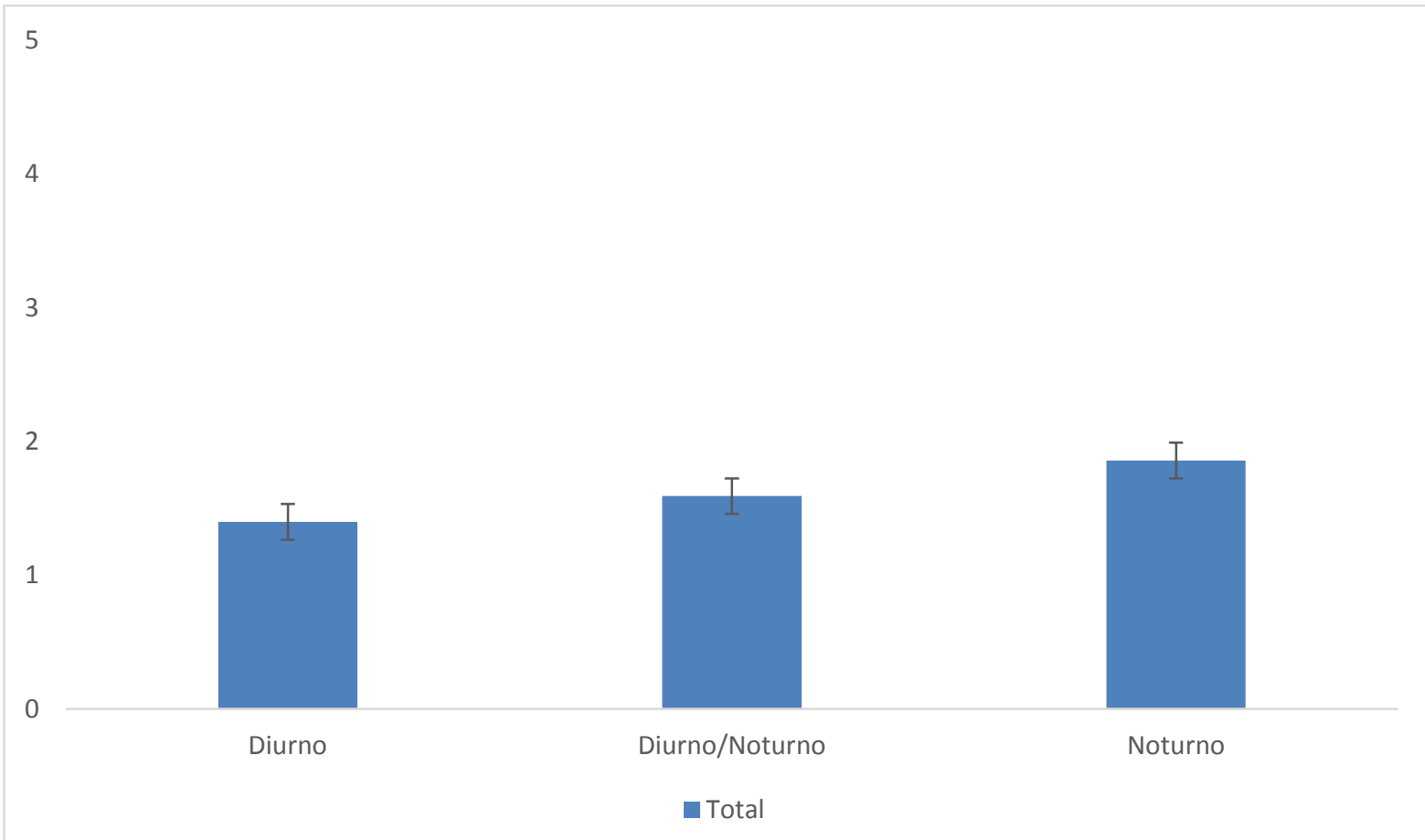

Entretanto, ao desdobrar os indicadores por turnos, verifica-se que no nível de representação Societal há penosidade de intensidade importante nas três dimensões e nos três turnos (Noturno Limite Subjetivo 4,0; Noturno Familiaridade 3,1; Noturno Poder 2,1; Diurno/Noturno Limite Subjetivo 2,9; Diurno/Noturno Familiaridade 2,7; Diurno/Noturno Poder 2,7 Diurno Limite Subjetivo 2,6; Diurno Familiaridade 2,4; Diurno Poder 2,2). Um ponto a ressaltar refere-se ao resultado do turno Noturno no Limite Subjetivo ter apresentado um grau próximo do insuportável. Não menos importantes são os resultados do nível de representação Interpessoal que nas dimensões Limite Subjetivo e Poder apresentaram graus de sofrimento psíquico correlato aos demais resultados (Noturno Limite Subjetivo 2,4; Noturno Poder 2,3; Diurno/Noturno Limite Subjetivo 1,7; Diurno/Noturno; Diurno/Noturno Poder 2,0 Diurno Limite Subjetivo 1,5; Diurno Poder 1,9). (Gráficos 21, 22 e 23) 
Grafico 21 - Penosidade turno - diurno

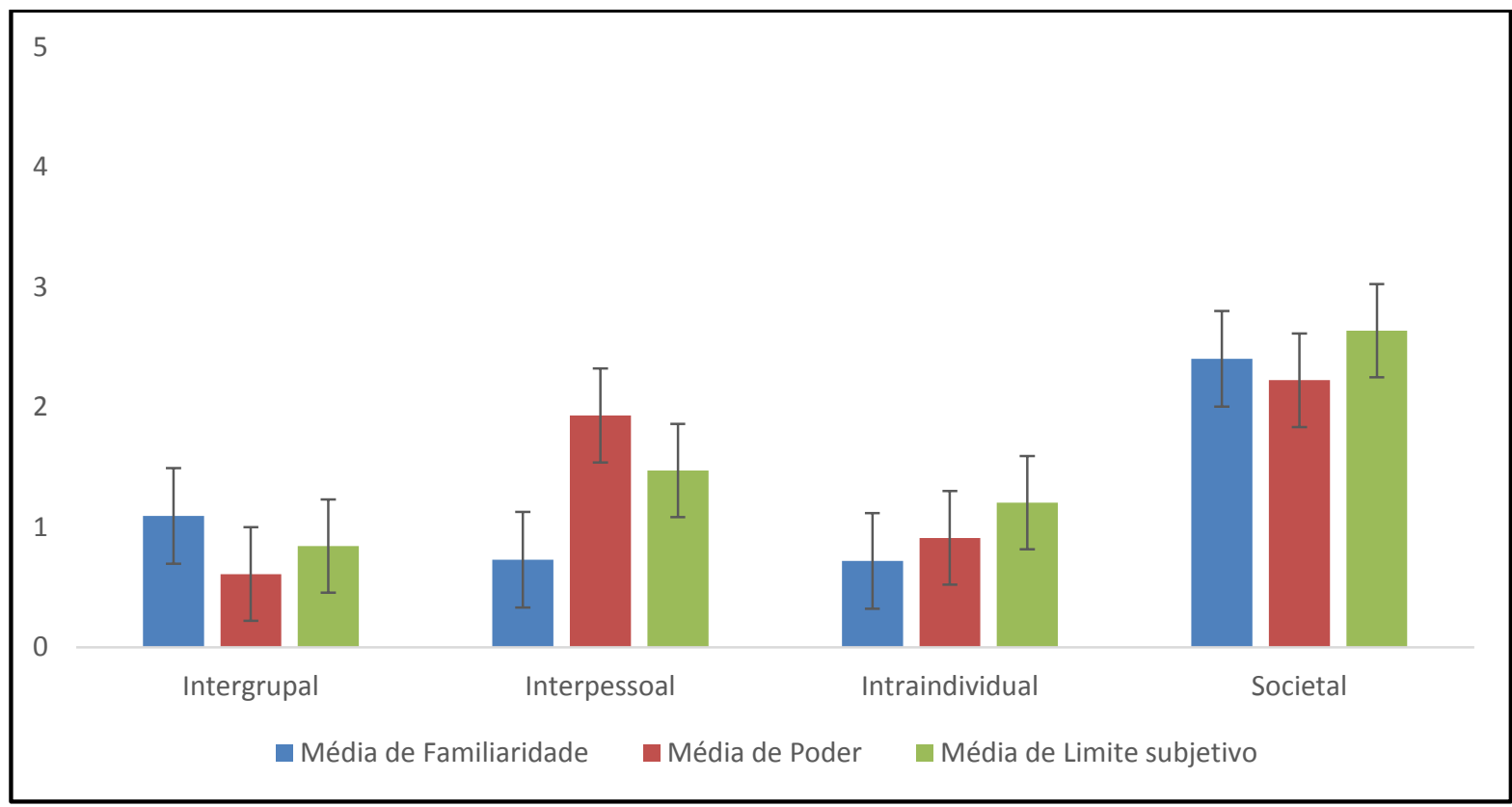

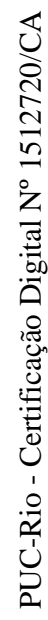

\section{Grafico 22 - Penosidade turno - noturno}

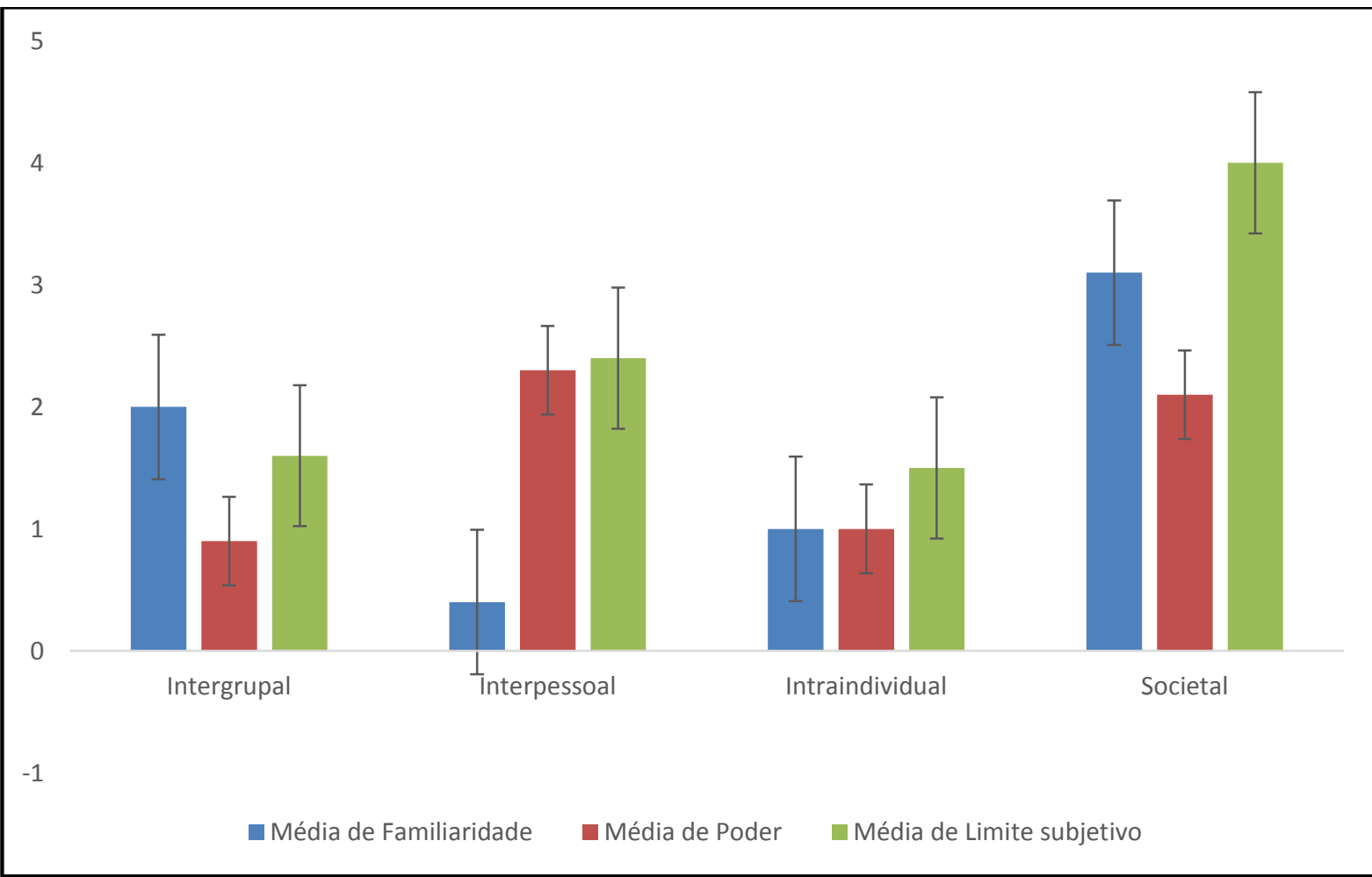




\section{Grafico 23 - Penosidade turno - diurno/noturno}

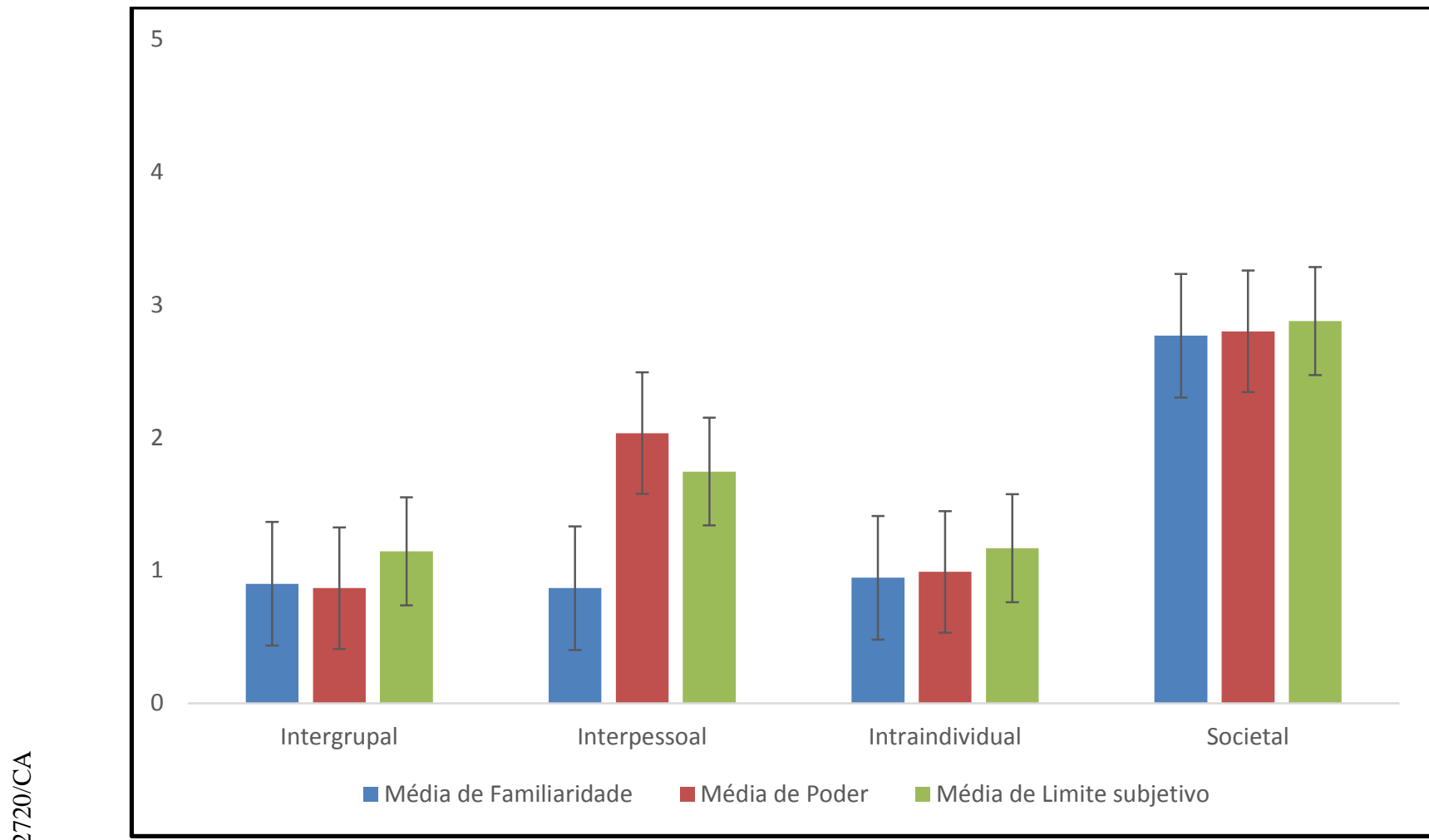

No que tange à escala de trabalho - diarista, plantonista e dupla matrícula, os resultados demonstram que o sofrimento psíquico afeta com maior intensidade aqueles sujeitos que atuam como plantonista e dupla matrícula, ambos com penosidade 1,6. (Gráfico 24) 


\section{Grafico 24 - Penosidade escala - total}

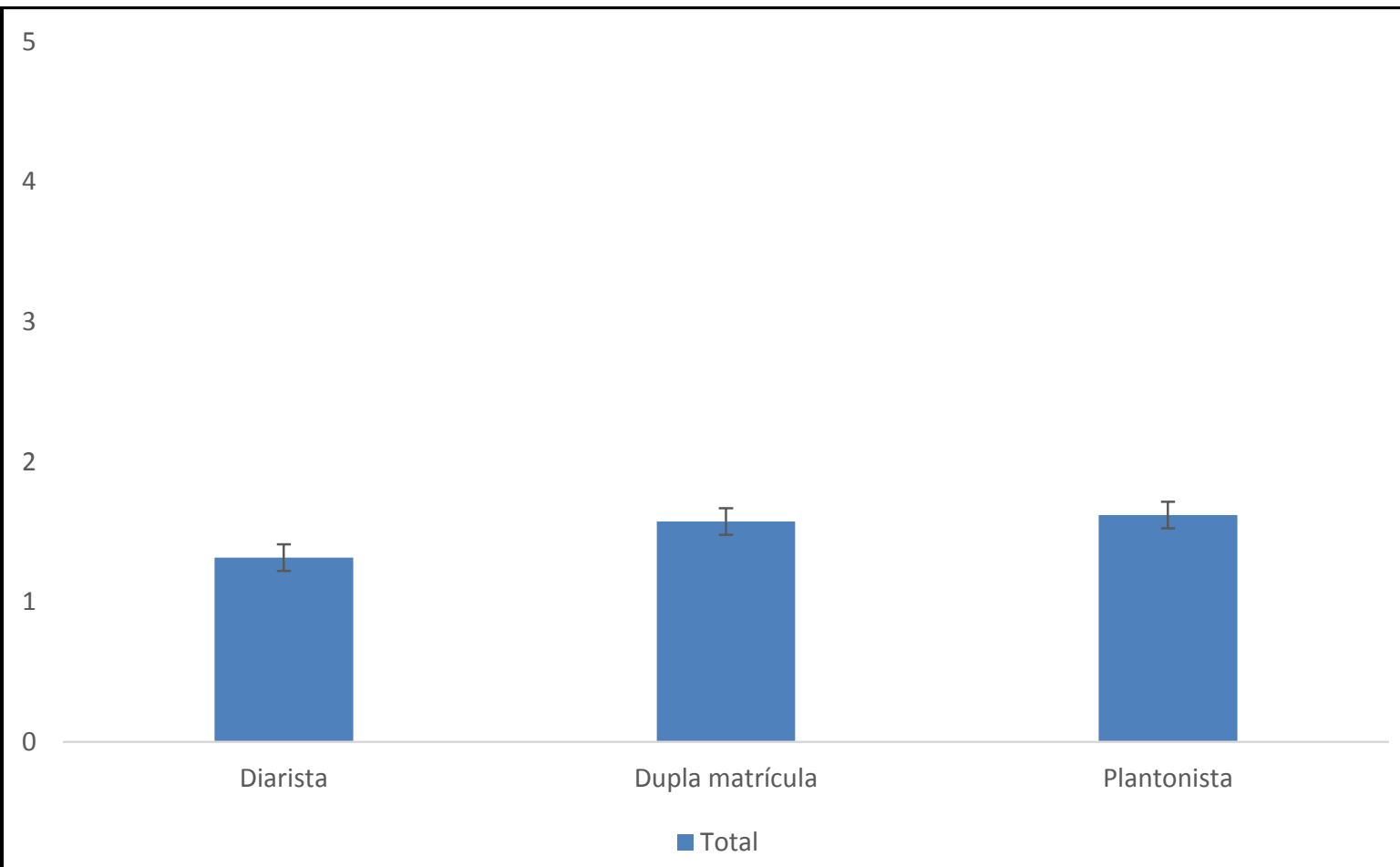

Com os indicadores por escala, desdobrados em dimensões e níveis de representação, verifica-se que no nível Societal há penosidade de alta intensidade nas três dimensões e nas três escalas (Dupla matrícula Limite Subjetivo 2,7; Dupla matrícula Familiaridade 3,6; Dupla matrícula Poder 3,7; Plantonista Limite Subjetivo 2,9; Plantonista Familiaridade 2,6; Plantonista Poder 2,5; Diarista Limite Subjetivo 2,6; Diarista Familiaridade 2,4; Diarista Poder 2,2). Um ponto a ressaltar refere-se ao resultado da escala Dupla matrícula nas dimensões Familiaridade (penosidade 3,7) e Poder (penosidade 3,6) ter apresentado graus de alta intensidade. Novamente os resultados do nível de representação Interpessoal que nas dimensões Limite Subjetivo e Poder apresentaram graus de sofrimento psíquico correlato aos demais resultados (Dupla matrícula Limite Subjetivo 1,7; Dupla matrícula Poder 1,7; Plantonista Limite Subjetivo 1,7; Plantonista Poder 2,1; Diarista Poder 1,9). (Gráficos 25, 26 e 27) 


\section{Grafico 25 - Penosidade escala - diarista}

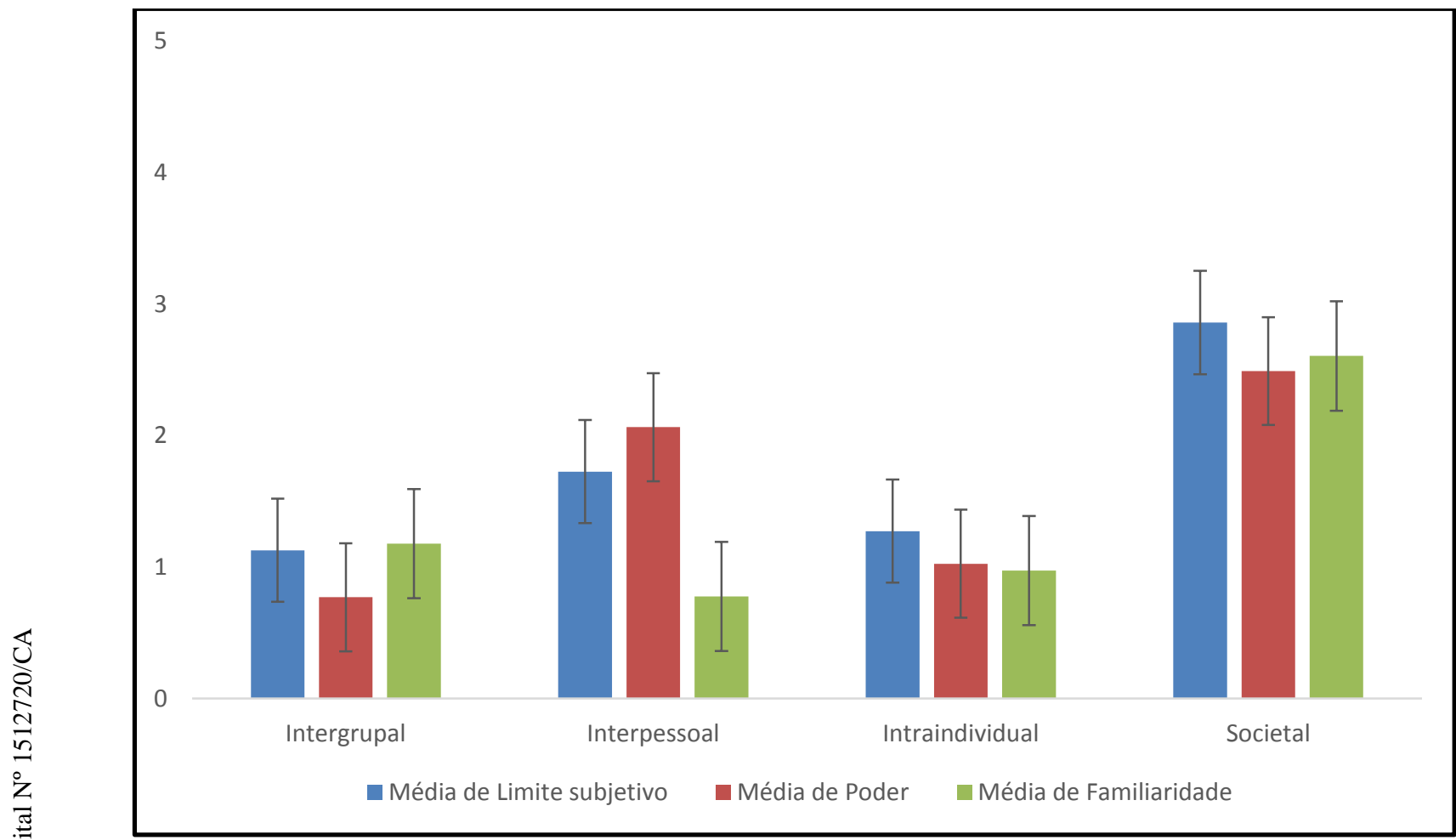

\section{Grafico 26 - Penosidade escala - plantonista}

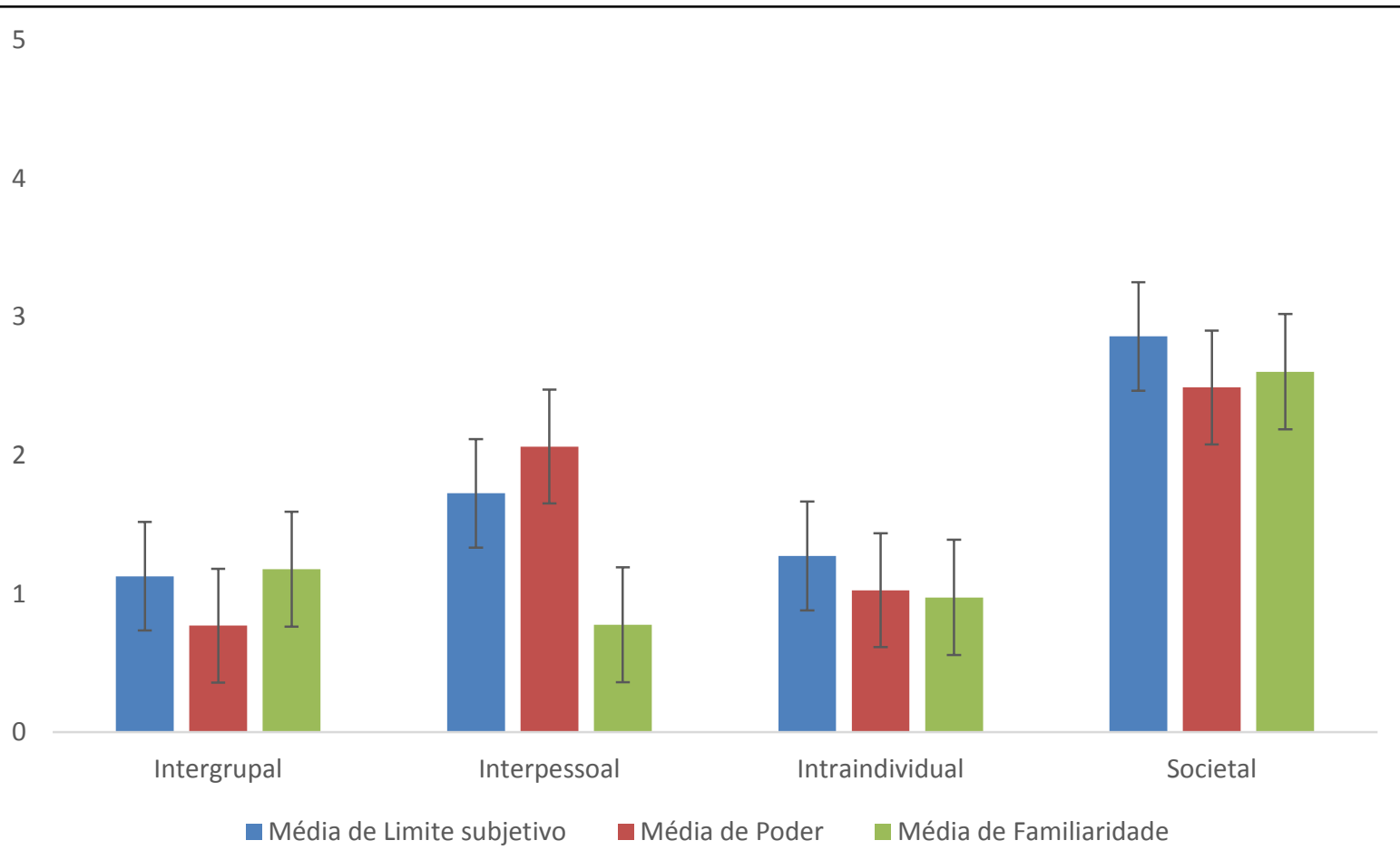




\section{Grafico 27 - Penosidade escala - dupla matrícula}

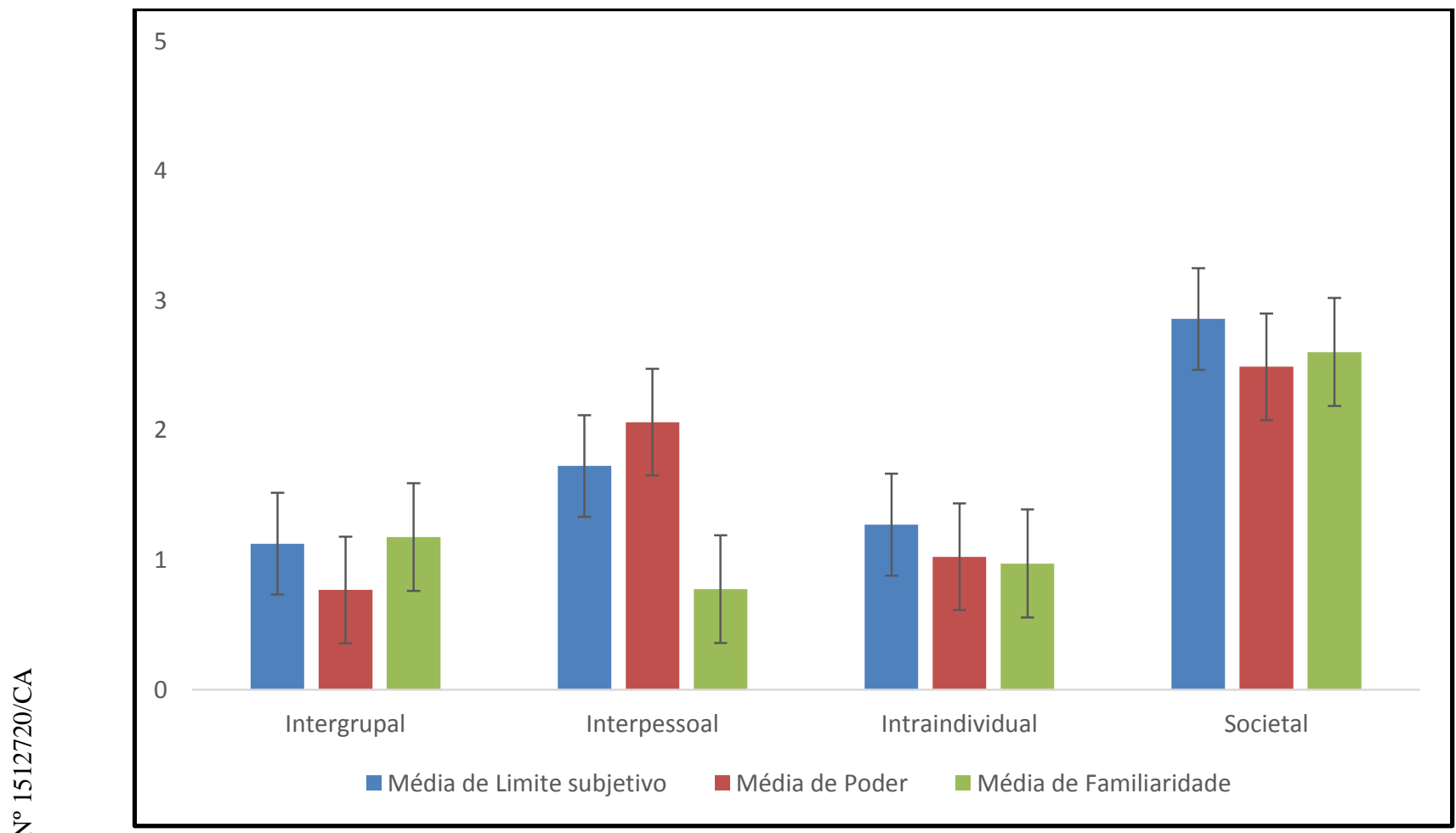

A variável sexo não apresentou distinção. Tanto o sexo feminino quanto o sexo masculino apresentaram resultados que indicam grau de penosidade 1,5. E, embora com alguma diferença numérica, o desenho gráfico dos resultados, enquanto níveis de representação por dimensão foram semelhantes e acompanhando as demais análises. (Societal Feminino Limite Subjetivo 2,8; Societal Feminino Familiaridade 2,5; Societal Feminino Poder 2,3; Societal Masculino Limite Subjetivo 2,7; Societal Masculino Familiaridade 2,6; Societal Masculino Poder 2,5; Interpessoal Feminino Limite Subjetivo 1,7; Interpessoal Feminino Poder 2,1; Interpessoal Masculino Limite Subjetivo 1,5; Interpessoal Masculino Poder 1,8). (Gráfico 28, 29 e 30) 
Grafico 28 - Penosidade sexo - ambos

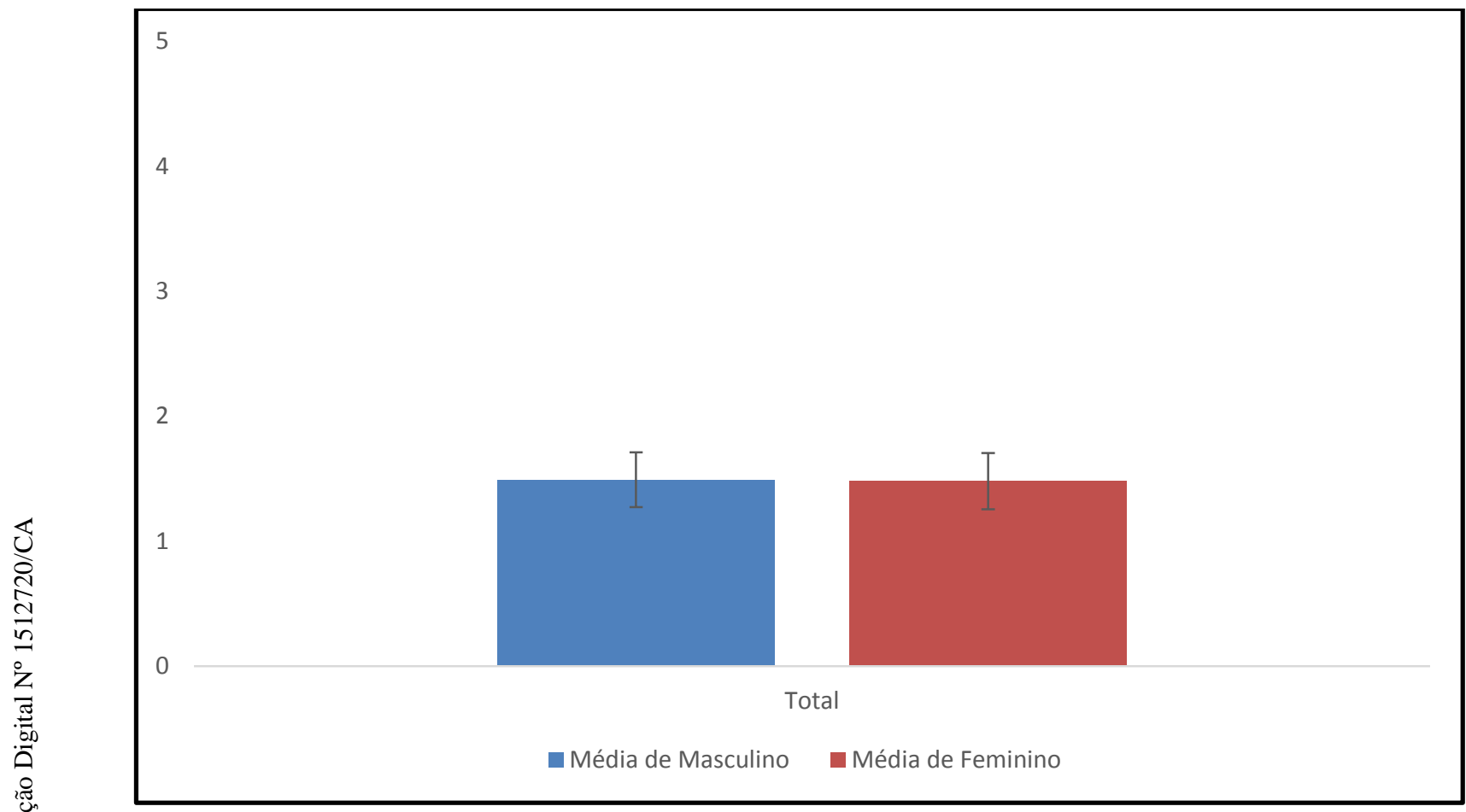

Grafico 29 - Penosidade sexo - feminino 


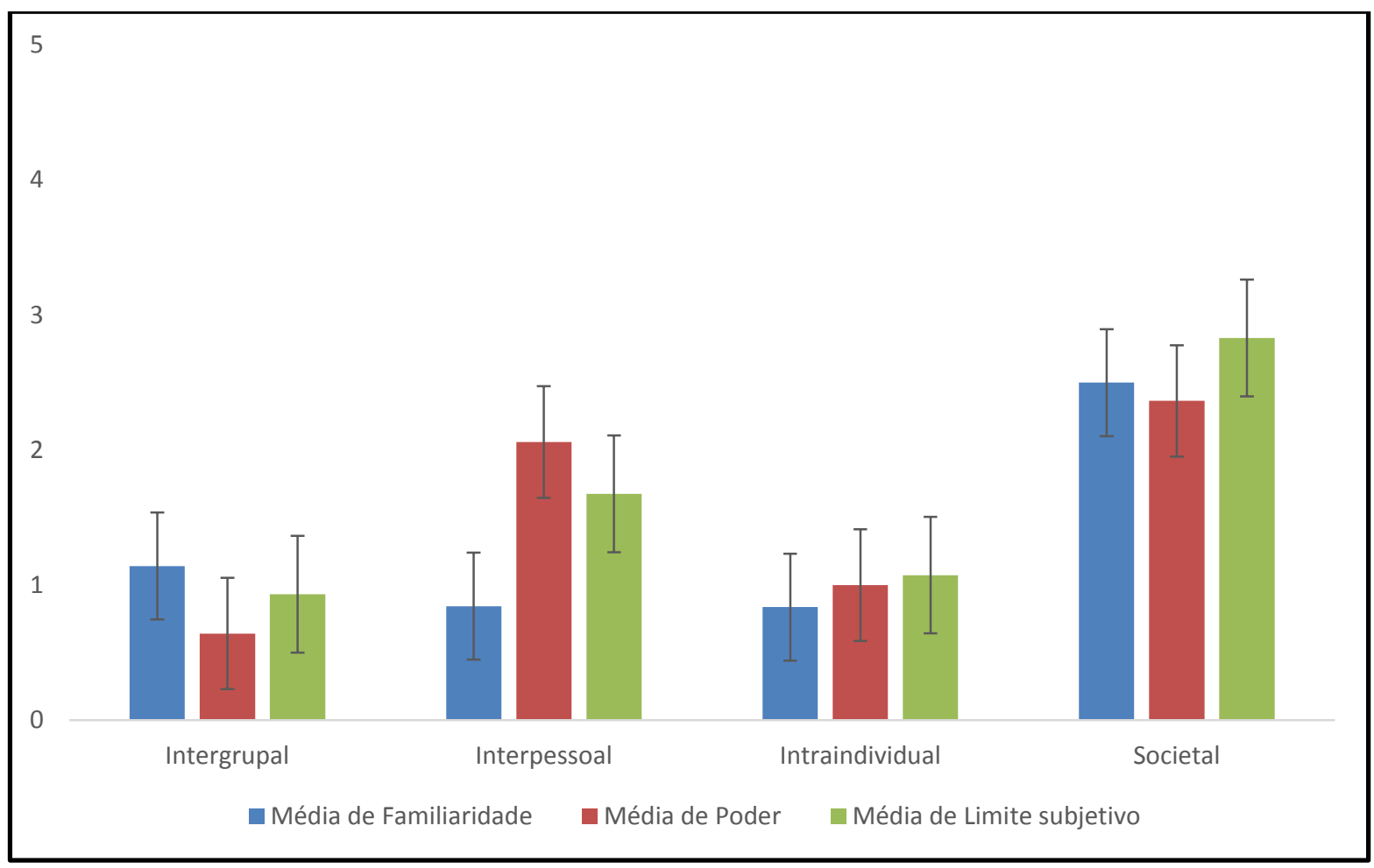

Uू.

\section{Grafico 30 - Penosidade sexo - masculino}

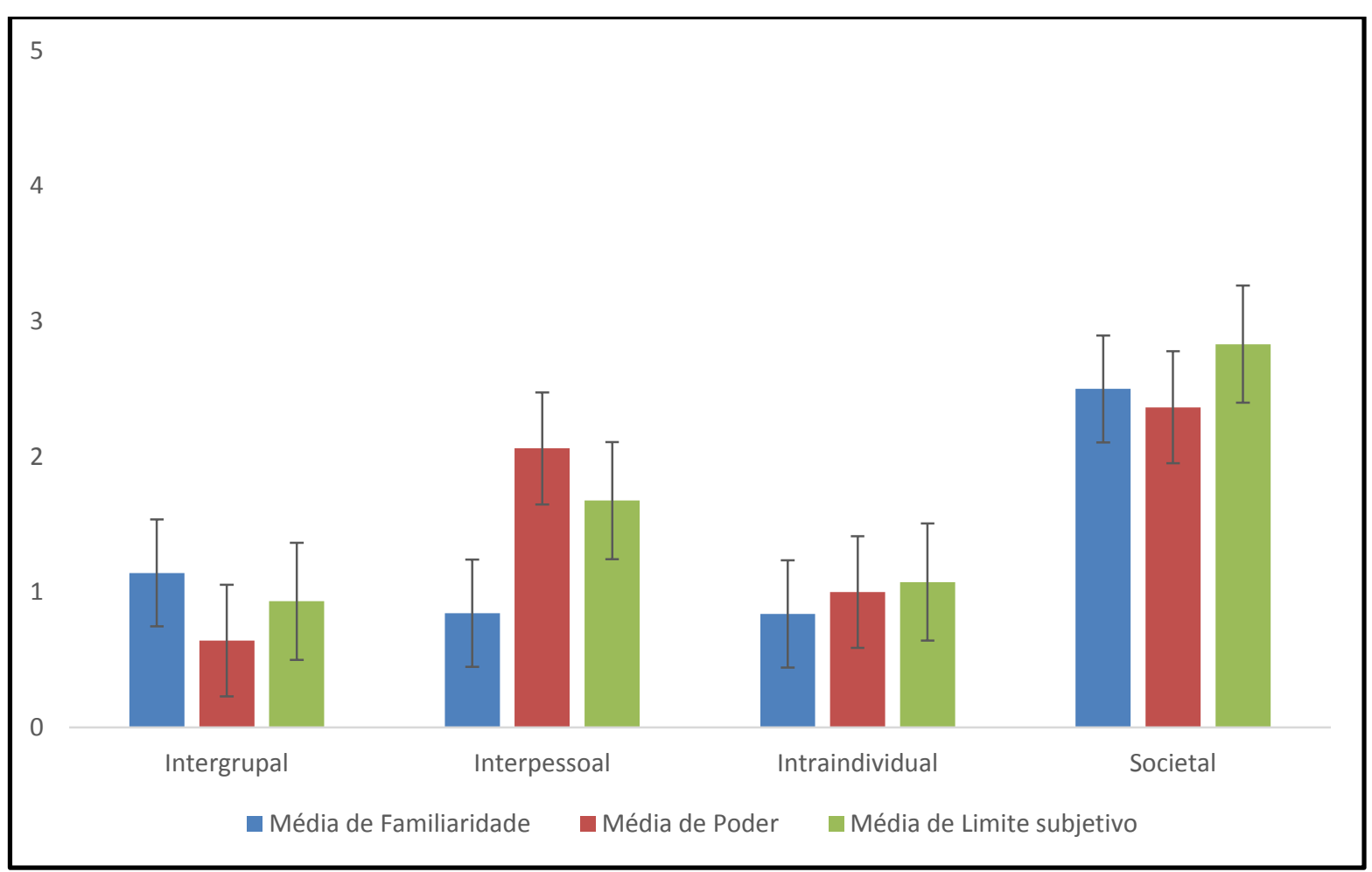


Quanto à faixa etária - 21-30; 31-40; 41-50; e, 51 ou mais, a diferença, embora pequena, mostram que os resultados acima de 1,5 estão nos sujeitos entre 41 e 50 ou mais $(1,6)$. Os níveis de representação por dimensão foram semelhantes e acompanhando as demais análises. (Societal 21-30 Limite Subjetivo 2,7; Societal 21-30 Familiaridade 2,5; Societal 21-30 Poder 2,3; Societal 31-40 Limite Subjetivo 2,7; Societal 31-40 Familiaridade 2,2; Societal 31-40 Poder 2,3; Societal 41-50 Limite Subjetivo 3,0; Societal 41-50 Familiaridade 2,7; Societal 41-50 Poder 2,8; Societal 41-50 Limite Subjetivo 3,0; Societal 41-50 Familiaridade 2,7; Societal 41-50 Poder 2,8; Societal 51-ou mais Limite Subjetivo 2,8; Societal 51-ou mais Familiaridade 2,7; Societal 51-ou mais Poder 2,3). Os índices mais altos referem-se à faixa etária 41-50 anos (Gráficos $31,32,33,34$ e 35$)$.

\section{Grafico 31 - Penosidade Faixa etária - Total}

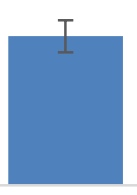

$31-40$

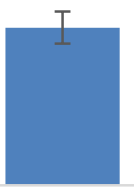

41-50

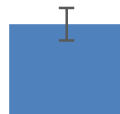

51 ou + 
Grafico 32 - Penosidade Faixa etária - 21 - 30

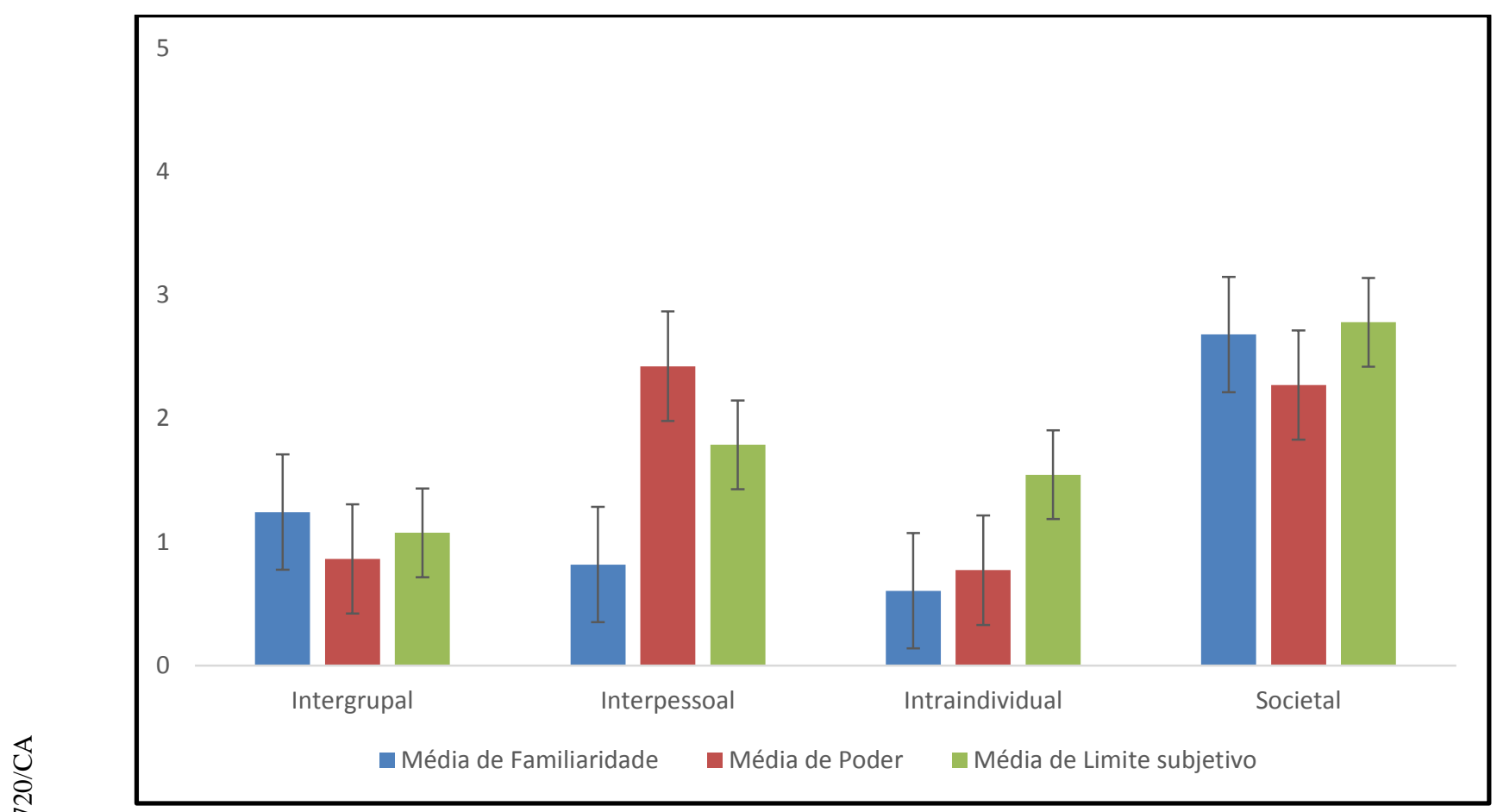

\section{Grafico 33 - Penosidade Faixa etária - 31 - 40}

3
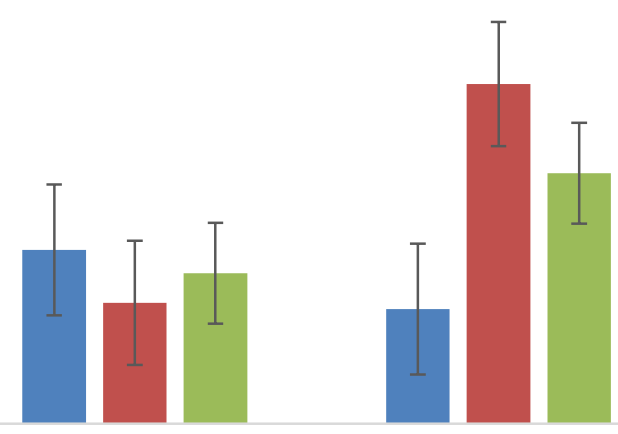

Interpessoal

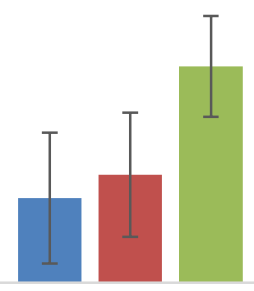

Intraindividual

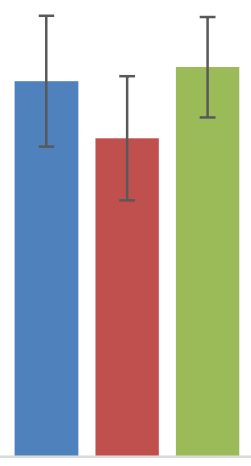

Societal 
Grafico 34 - Penosidade Faixa etária - 41 - 50

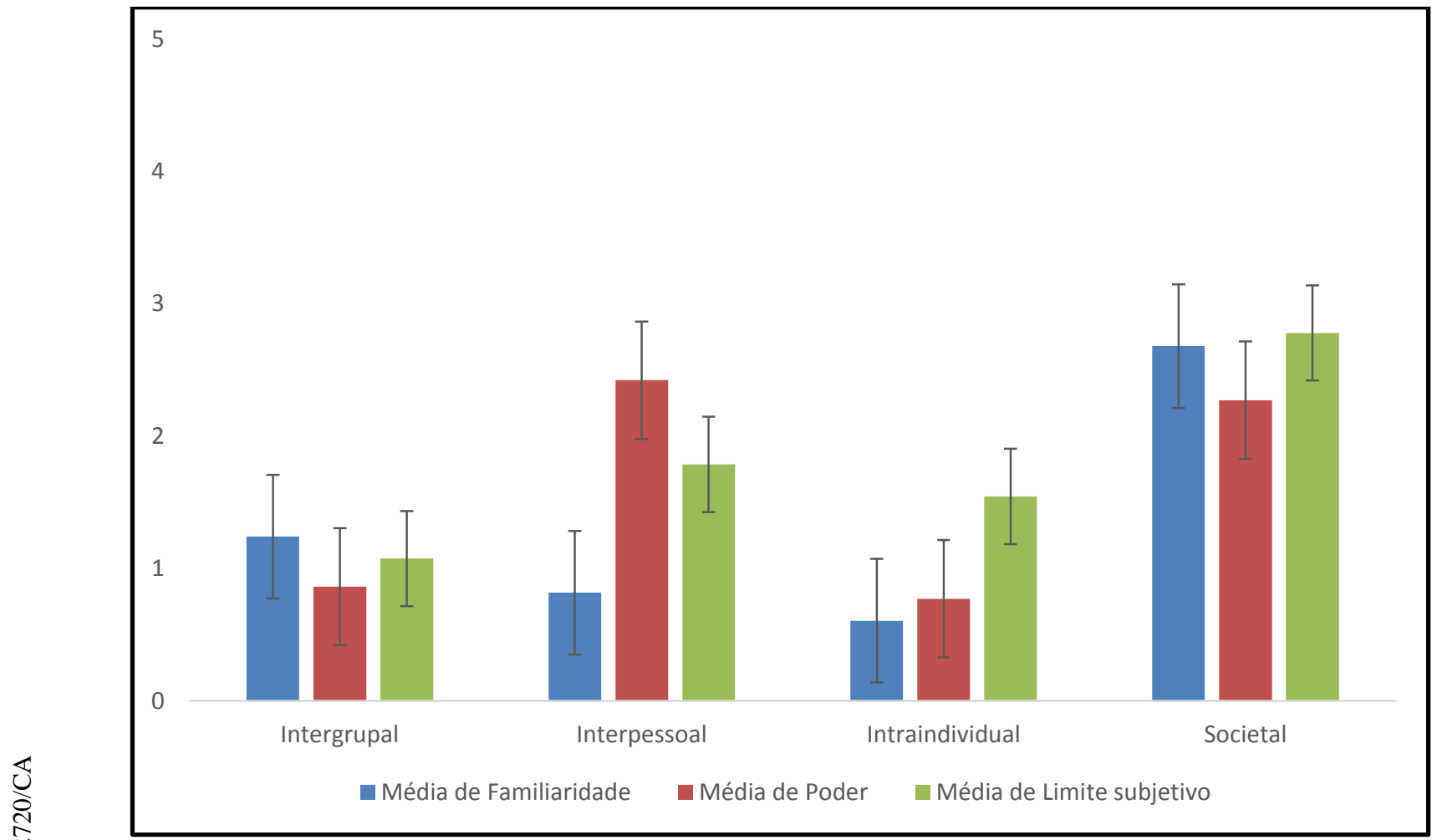

Grafico 35 - Penosidade Faixa etária - 51 - mais

4

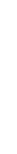

1
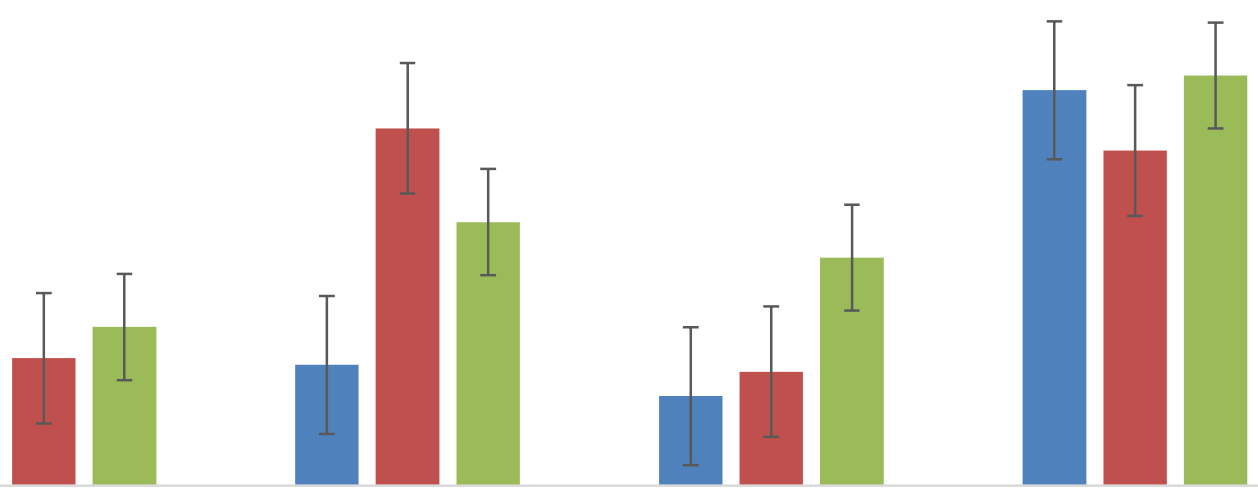

Intergrupal

Interpessoal

Intraindividual

Societal 
Quanto ao tempo na ocupação, tempo na emergência; e, tempo no Hospital Municipal Miguel Couto - HMMC; a penosidade também está com seus maiores índices no nível de representação Societal e Interpessoal. Os níveis de representação por dimensão foram semelhantes e acompanhando as demais análises. (TO Societal 0,1-10 Familiaridade penosidade 2,5; TO Societal 0,1-10 Limite Subjetivo penosidade 2,7; TO Societal 0,1-10 Poder penosidade 2,4; TO Interpessoal 0,1-10 Limite Subjetivo penosidade 1,5; TO Interpessoal 0,1-10 Poder penosidade 1,7; TO Societal 11-mais Familiaridade penosidade 2,6; TO Societal 11-mais Limite Subjetivo penosidade 2,9; TO Societal 11-mais Poder penosidade 2,5; TO Interpessoal 11-mais Poder penosidade 2,3; TO Interpessoal 11-mais Limite Subjetivo penosidade 1,7 (TE Societal 0,1-10 Familiaridade penosidade 2,5; TE Societal 0,1-10 Limite Subjetivo penosidade 2,7; TE Societal 0,1-10 Poder penosidade 2,4; TE Interpessoal 0,1-10 Limite Subjetivo penosidade 1,6; TE Interpessoal 0,1-10 Poder penosidade 1,8; TE Societal 11-mais Familiaridade penosidade 2,6; TE Societal 11-mais Limite Subjetivo penosidade 2,9; TE Societal 11-mais Poder penosidade 2,4; TE Interpessoal 11-mais Limite Subjetivo penosidade 1,6; TE Interpessoal 11-mais Poder penosidade 2,3; (THMMC Societal 0,1-10 Familiaridade penosidade 2,5; THMMC Societal 0,110 Limite Subjetivo penosidade 2,8; THMMC Societal 0,1-10 Poder penosidade 2,4; THMMC Interpessoal 0,1-10 Limite Subjetivo penosidade 1,6; THMMC Interpessoal 0,1-10 Poder penosidade 1,8; THMMC Societal 11-mais Familiaridade penosidade 2,7; TO Societal 11-mais Limite Subjetivo penosidade 2,8; THMMC Societal 11-mais Poder penosidade 2,5; THMMC Interpessoal 11mais Limite Subjetivo penosidade 1,6; THMMC Interpessoal 11-mais Poder penosidade 2,2. (Gráficos 36, 37 e 38).

\section{Grafico 36 - Penosidade Tempo na ocupação - TO, por dimensão e nível de representação}




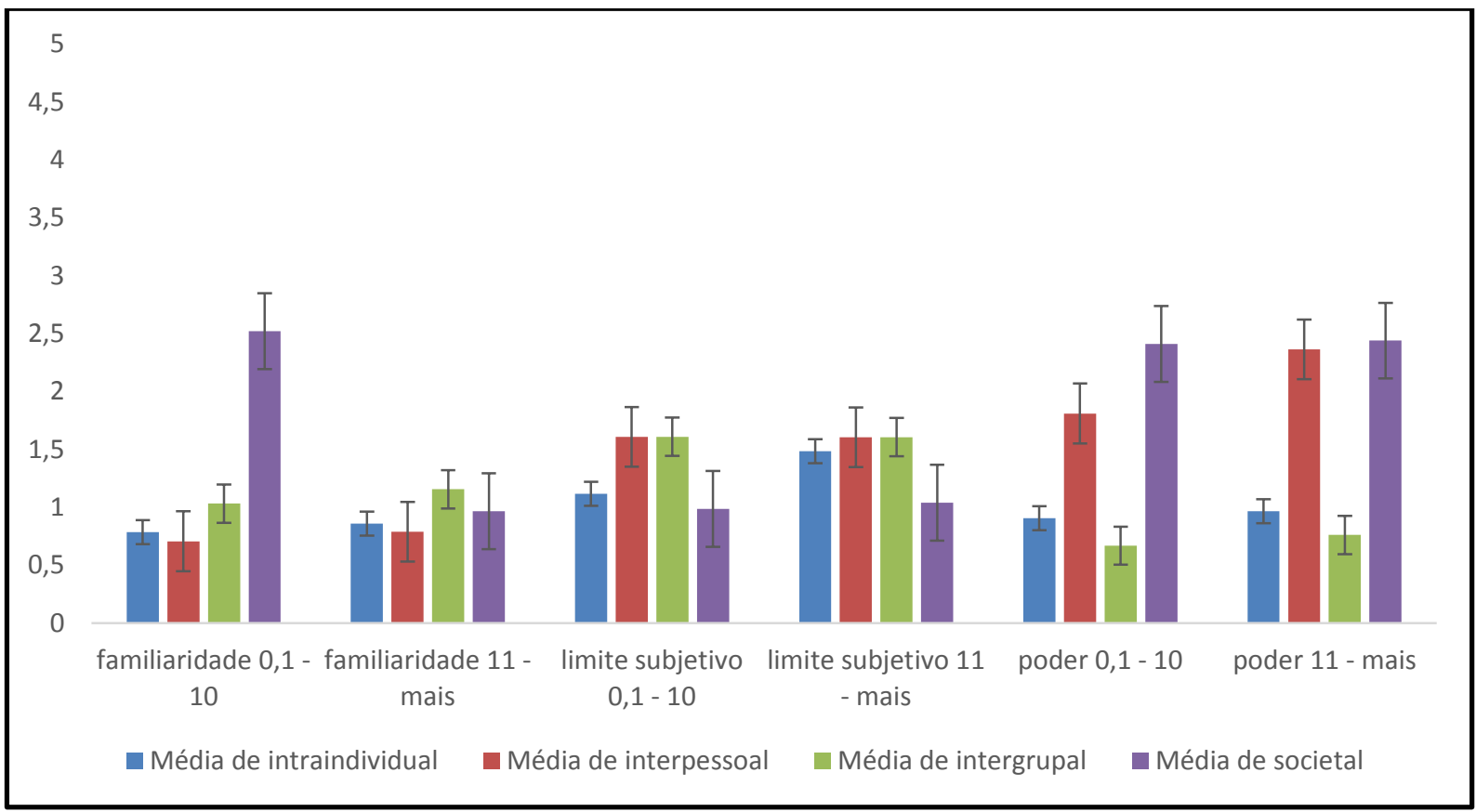
nível de representação 

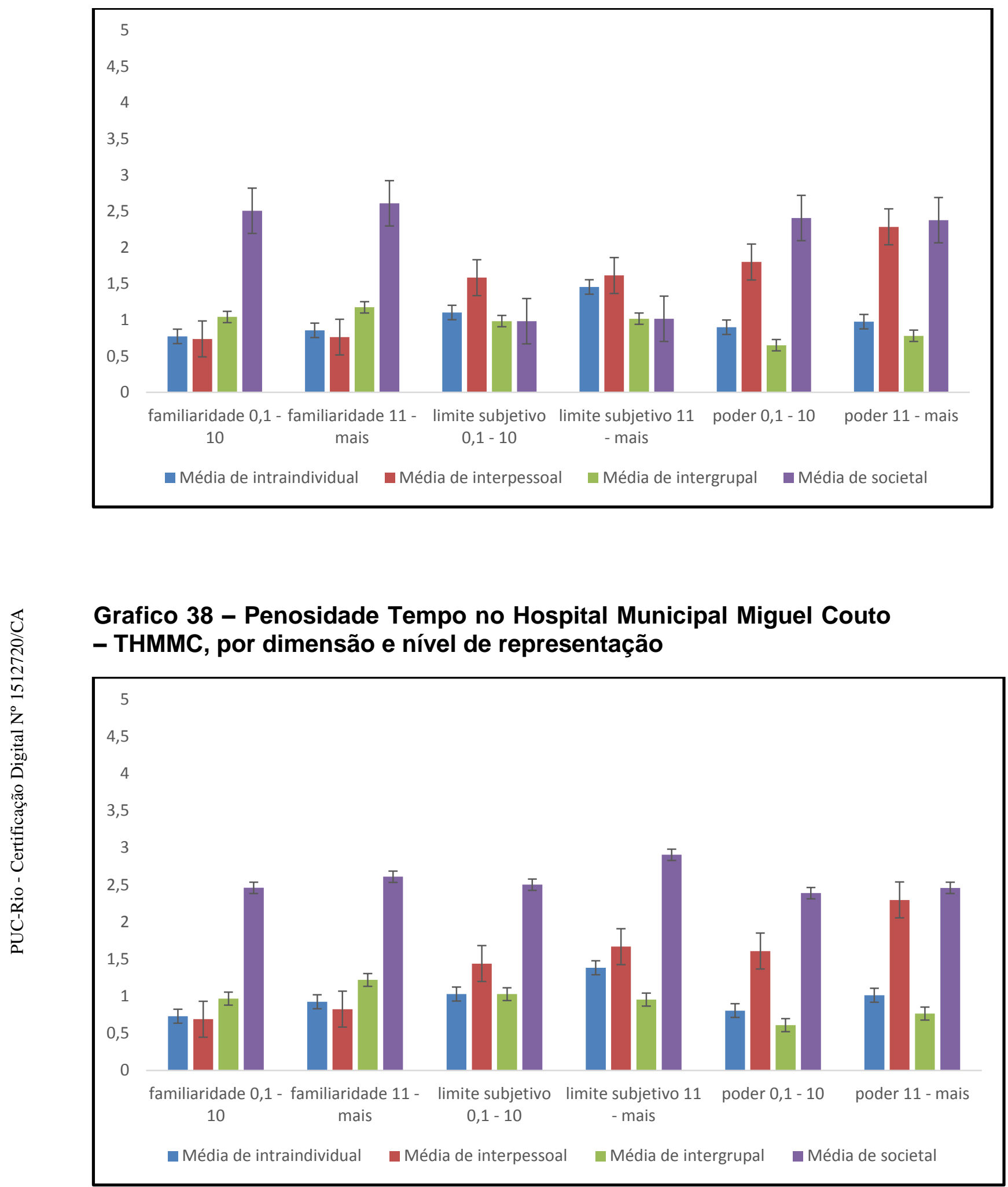

No que se refere à penosidade Moradia / Núcleo Familiar, os indicadores apontam para homogeneidade nos resultados com uma leve diferença nos sujeitos que habitam Com Cônjuge (penosidade 1,7) ou Sozinhos $(1,6)$. (Gráfico 4 


\section{Grafico 39 - Penosidade Moradia Núcleo}

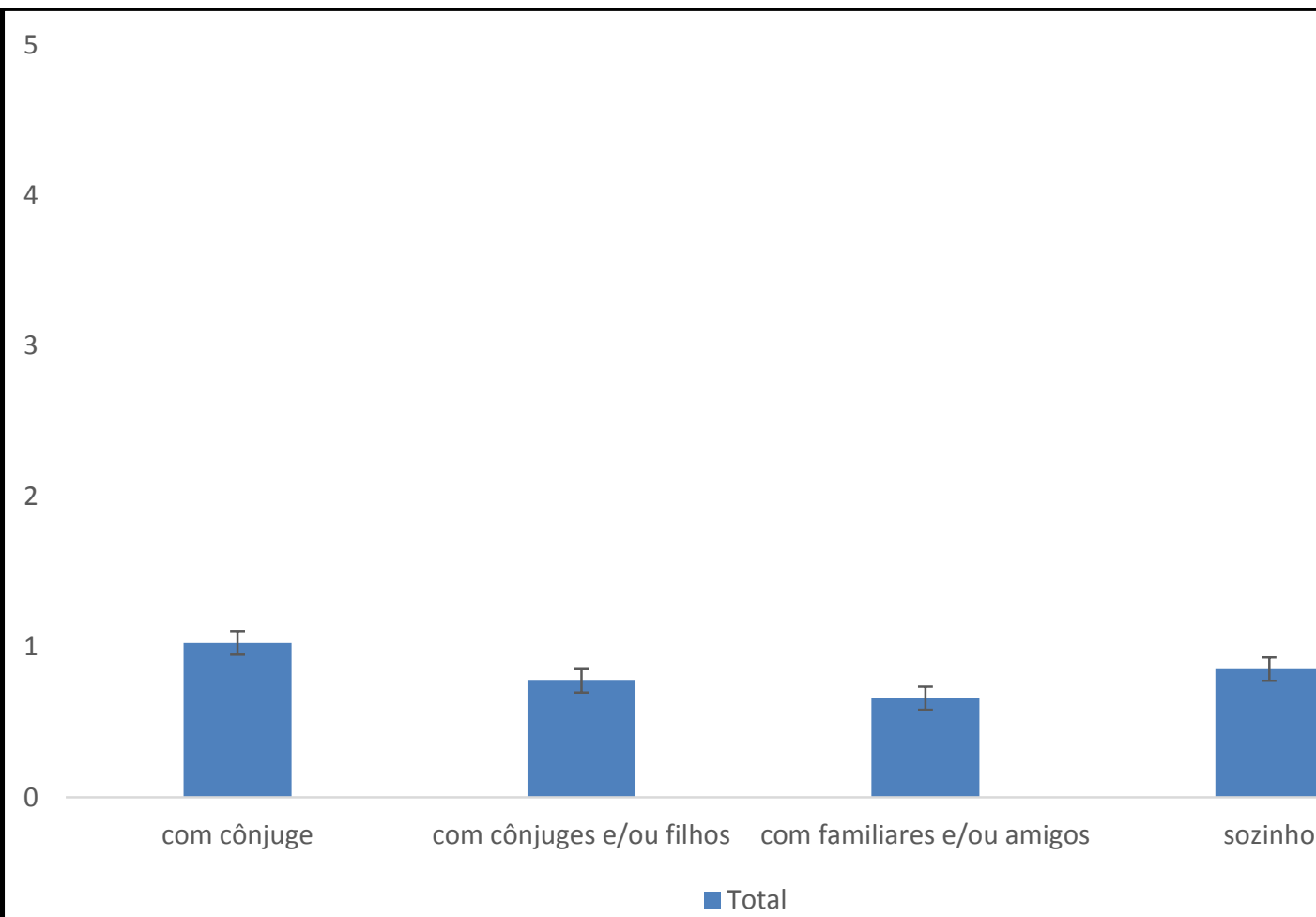


Em relação à penosidade por Responsabilidade Financeira / Núcleo Familiar, os indicadores apontam, também, para homogeneidade nos resultados com uma leve diferença nos sujeitos que respondem pelo provimento Parcial $(1,6)$ e Total $(1,5)$ no Núcleo Familiar. (gráfico 41)

Grafico 40 - Penosidade Responsabilidade Financeira Núcleo Familiar

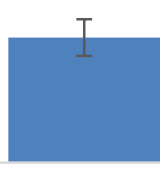

parcial

- Total

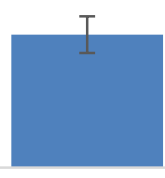

$\operatorname{sim}$ 


\subsubsection{Análises inferenciais}

Diferenças na variável sociodemográfica (idade e sexo) foram mensuradas por meio do teste qui-quadrado. Uma ANOVA de medidas repetidas com fator intra-grupos (3): poder, limite subjetivo e familiaridade foi calculada para diferenças nos escores médios, seguida de um teste post-hoc ajustado com correção tipo Bonferroni. Ainda, foi rodada uma ANCOVA para variável sexo a fim de controlar para eventuais diferenças.

A medida Kaiser-Meyer-Olkin (KMO) foi calculada para avaliar a adequação da amostra para condução de uma análise fatorial exploratória. Foi proposto que os valores KMO deveriam ser iguais ou maiores a .60 no sentido de interpretar de forma mais satisfatória a análise fatorial (Tabachnick \& Fidell, 2001). O método de extração PAF foi selecionado, além do fator de rotação oblíquo que foi utilizado (promax, $\delta=0$ ). A análise do scree plot, a inspeção dos eigenvalues (Hayton, Allen \& Scarpello, 2004) foi empregada para determinar o número de fatores.

Entre os 249 participantes testados no estudo, 114 participantes participavam do grupo (1) Profissionais das Ciências, 53 do grupo (2) Técnico de nível médio, 25 do grupo (3) Trabalhadores administrativos, 36 do grupo (4) Trabalhadores dos Serviços e 21 do grupo (5) Estudantes. O número de participantes do sexo feminino foi $(n=150)$, o total de sujeitos do sexo masculino foi $(n=99)$.

Um teste qui-quadrado foi calculado para a variável sexo $\mathrm{X}^{2}(1)=10.44$, $\mathrm{p}<.001$ sendo encontrada uma tendência no sentido feminino-masculino em relação ao total de participantes. O mesmo teste também foi calculado para a variável idade $\mathrm{X}^{2}(3)=7.46, \mathrm{p}>0.5$ não encontrando diferenças entre os participantes.

O escore para o instrumento foi calculado através de uma ANOVA de medidas repetidas que mostrou um efeito significativo para dimensão $F(2,490)$ $=16.947, p<.001, \eta^{2}=.06$, de nível $F(3,735)=202.284, p<.001, \eta^{2}=.45$ e da interação dimensão*nível $F(6,1470)=17.981, \quad p<.001, \eta^{2}=.07$ mostrando diferenças significativas entre os grupos. Conforme mostra o gráfico 42. 


\section{Grafico 41 - ANOVA Dimensão / Nível de Representação}

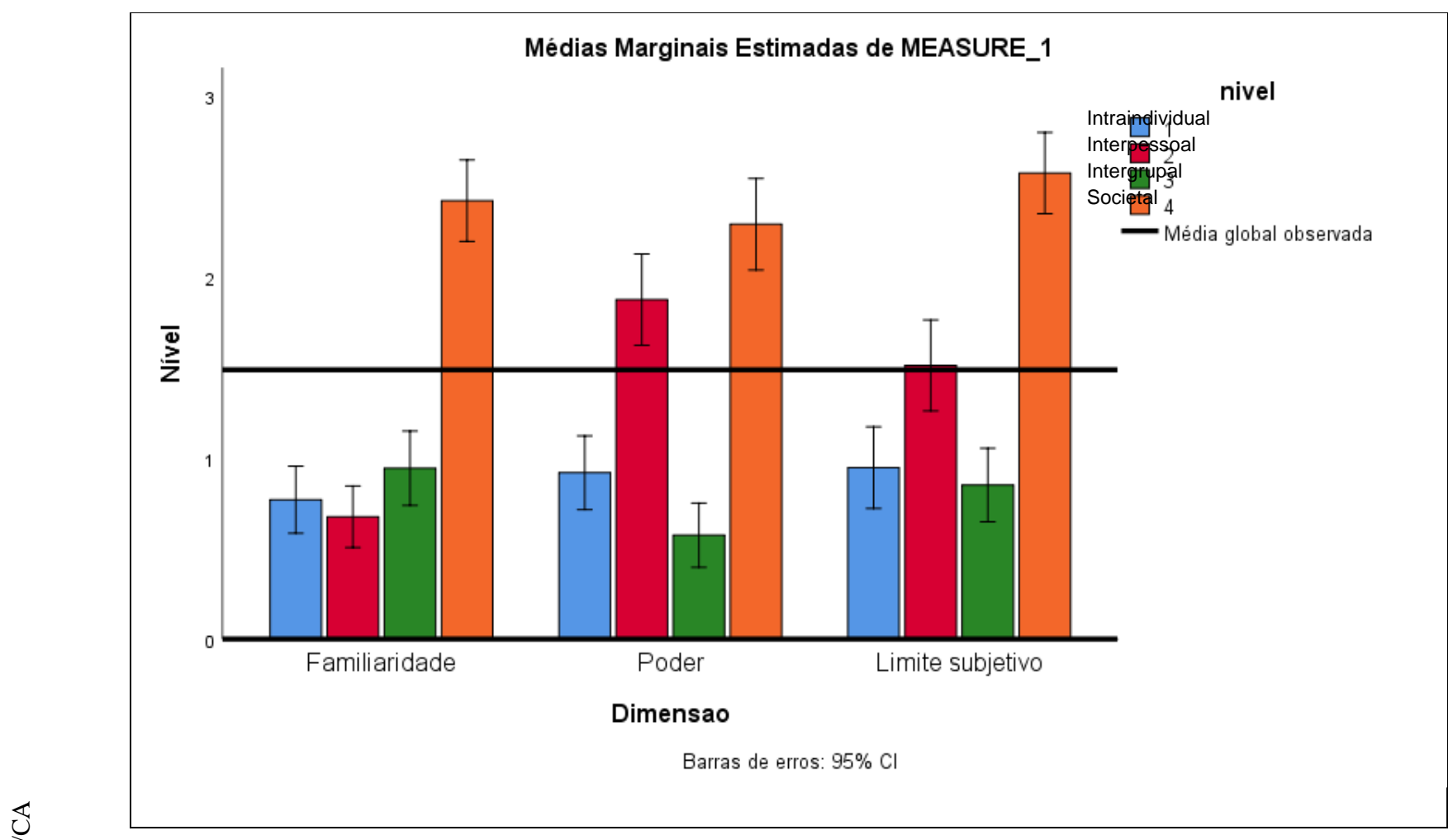

Em relação aos testes post-hoc executados, foram encontradas diferenças em relação ao grupo Profissionais das Ciências comparado com Trabalhadores de Serviços e Estudantes $(\mathrm{p}=.01)$; grupo Técnico de nível médio em relação à Trabalhadores administrativos, Trabalhadores dos Serviços e Estudantes (<.05); grupo Trabalhadores dos Serviços para Profissionais das Ciências $(\mathrm{p}<.05)$ e Técnico de nível médio ( $\mathrm{p}<.01)$; e, grupo Estudantes comparado à Profissionais das Ciências $(\mathrm{p}<0.5)$ e Técnico de nível médio ( $\mathrm{p}<.01)$. Uma ANCOVA foi calculada para a variável sexo $F(1,244)=2.772, \mathrm{p}=.094$ sobre as variáveis dimensão e nível.

\subsubsection{Análise fatorial}

Considerando-se a fidedignidade como uma das propriedades mais elementares de um instrumento, foi utilizado um parâmetro consagrado na literatura. Trata-se do Alfa de Cronbach. Além disso, foi realizada a Análise de Itens em relação a todos os itens que compõe a Escala. Neste caso, pode-se calcular a Correlação Item Total de cada um dos itens. Para a avaliação da validade de constructo foi realizada a Análise Fatorial Exploratória (Data Driven) 
para verificar até que ponto todos os itens que compõe o instrumento se constituem como Fatores que explicam os dados produzidos por este instrumento.

Para investigar a consistência interna da escala, o Alfa de Cronbach foi calculado para a escala completa e para os fatores extraídos. O índice de KaiserMeyer-Olkin (KMO) foi utilizado para determinar a adequação da amostragem para uma análise fatorial exploratória. Tabachnick e Fidell (2001) sugerem que os valores de KMO devem ser iguais ou maiores a .60 para que seja possível interpretar satisfatoriamente uma análise fatorial. Uma análise de componentes principais não foi utilizada, pois esse procedimento infla as estimativas de variância (COSTELLO \& OSBORNE, 2005). Em seu lugar, uma principal axis factoring foi usada como método de extração, com uma rotação oblíqua sendo empregada (promax, $\delta=0$ ) em função de potenciais correlações entre os fatores. O número de fatores foi determinado a partir do exame do scree plot e dos eigenvalues (HAYTON, ALLEN \& SCARPELLO, 2004).

O alfa de Cronbach para a escala completa chegou perto de níveis aceitáveis $(\alpha=.68)$, indicando razoável consistência interna (GEORGE \& MALLERY, 2003). A média das correlações item-total corrigidas foi moderada $(r=.32)$, variando de $\mathrm{r}=.45$ (item familiaridade societal) até $\mathrm{r}=.19$ (item familiaridade interpessoal). A remoção de um dos itens não levaria a melhoras na consistência interna.

A análise do índice KMO revelou um valor de .75, indicando boa adequação de amostragem e que a matriz correlacional era apropriada para a análise fatorial. $\mathrm{O}$ item de poder intraindividual apresentou comunalidade baixa (.08) e foi excluído de análises subsequentes.

A análise do scree plot e dos eigenvalues sugeriu uma solução de 3 fatores que respondem por $42.5 \%$ da variância. Os resultados da matriz estrutural e da matriz padrão foram similares, com os últimos sendo reportados em função de serem mais conservadores (BROWN, 2006; HATCHER, 1994). A Tabela 7 apresenta as cargas fatoriais para essa solução de 3 fatores. O gráfico 43 mostra Scree plot parar análise dos eigenvalues.

A solução de três fatores apresentou uma estrutura bem definida, com os itens apresentando cargas salientes em apenas um fator. Apenas um item hiperplano (sem carga relevante em nenhum fator) foi encontrado (MATSUNAGA, 2010). O primeiro fator foi responsável por $24.1 \%$ da variância 
e apresentava um eigenvalue de 2.7. Este fator contém os itens Familiaridade Societal (.67); Poder Intergrupal (.58); Poder Societal (.82); Limite Subjetivo Intraindividual (.77); Limite Subjetivo Intergrupal (.88); e Limite Subjetivo Societal (.81). O segundo fator foi responsável por $11.1 \%$ da variância, com um eigenvalue de 1.2, contendo itens Familiaridade Intraindividual (.72), Familiaridade Interpessoal (.79); e Familiaridade Intergrupal (.65) . Finalmente, o terceiro fator foi responsável por $10.2 \%$ da variância, com eigenvalue de 1.1, incluindo itens Poder Interpessoal (.73) e Limite Subjetivo Interpessoal (.76). A consistência interna dos fatores foi baixa (Fator 1: $\alpha=.57$; Fator 2: $\alpha=.47$; Fator 3: $\alpha=.42)$. 
Tabela 7 - Matriz Padrão

\begin{tabular}{|c|c|c|c|c|c|}
\hline item\#\# & Item & Fator 1 & Fator 2 & Fator 3 & Comunalidade \\
\hline 1 & Famliaridade Intaindividual & 08 & .72 & .06 & .64 \\
\hline 2 & Farriliariade Interpessoal & -.11 & .79 & .16 & .64 \\
\hline 3 & Farnliaridade Intergrupal & .15 & .65 & -28 & .47 \\
\hline 4 & Farnliaridade Societal & .67 & -102 & .05 & .59 \\
\hline 6 & Poder Interpess oal & -.18 & -01 & .73 & .55 \\
\hline 7 & Poder Intergnpal & 58 & 04 & -21 & .35 \\
\hline 8 & Poder Societal & 82 & -04 & .21 & .79 \\
\hline 9 & Limite Subjetivo Intraindividual & .77 & 01 & .05 & .70 \\
\hline 10 & Limite Subjetiwo Interpessoal & .16 & 01 & .76 & .72 \\
\hline 11 & Linite Subjetivo Intergnpal & 88 & -04 & -05 & .71 \\
\hline 12 & Limite Subjetivo Socital & 81 & .13 & -05 & .69 \\
\hline Eigenvahe & & 2.7 & 12 & 1.1 & \\
\hline - Variância(\%) & & 24.1 & 11.1 & 102 & \\
\hline 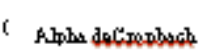 & & 57 & 47 & .42 & \\
\hline
\end{tabular}

\section{Grafico 42 - Scree plot parar análise dos eigenvalues}

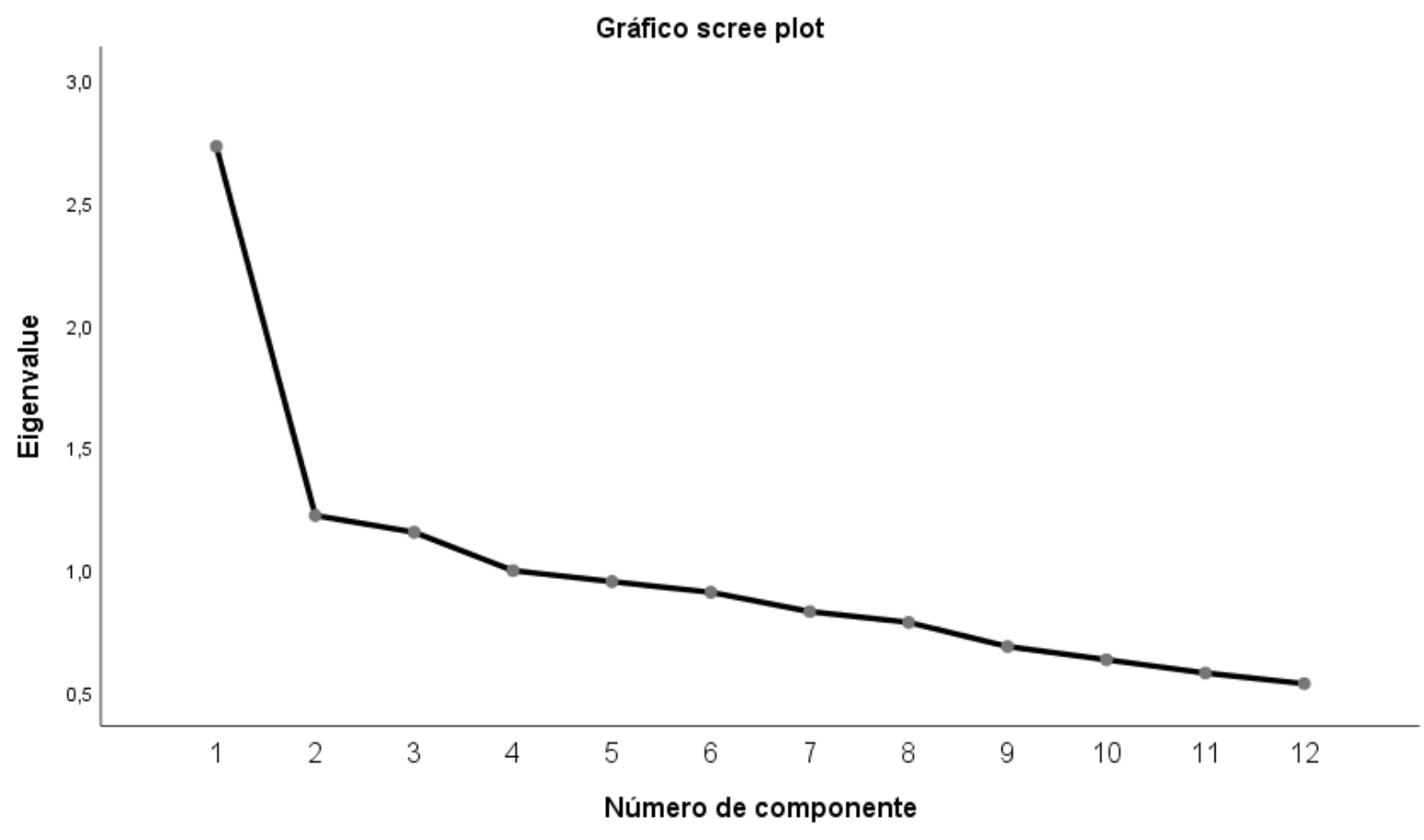




\section{Discussão}

Considerando o resultado geral, por dimensão verificou-se que a percepção de sofrimento psíquico dos sujeitos, pelo discurso nas entrevistas, está relacionada à percepção em relação à autonomia na realização do trabalho e o quanto, como e até quanto podem suportar este tipo de sofrimento. E, estas percepções imbricam no processo de aproximação gradativa com o trabalho. Um ponto a ressaltar se refere ao papel da atuação em equipe como parte importante na amenização do tipo de sofrimento apresentado. Esse fato aponta para a relevância das estratégias coletivas de defesa, positivadas pelo desenvolvimento, técnico e interpessoal, do trabalho em equipe representado pelos sujeitos avaliados. Outro ponto a ressaltar é a existência de protocolos e procedimentos padrão, que, no entanto, precisam ser periodicamente revisados e, de fato, utilizados no cotidiano do trabalho destas equipes.

Como estes sujeitos representam estas percepções de sofrimento psíquico? Considerando todas as ocupações, é possível verificar que o nível Societal (penosidade 2,6) se distingue dos demais. A representação dos funcionários que atuam na emergência do HMMC demonstra que os sistemas de crenças, representações, avaliações e normas sociais relacionadas à gestão da saúde no serviço público os afetam, de forma que não percebem formas de utilização de estratégias de defesa. E esse fenômeno, em seguimento, pode levá-los ao desenvolvimento de Síndrome de Burnout. É possível pensar que, de forma geral, estes trabalhadores que atuam na emergência de um hospital público, mal conseguem construir estratégias de defesa e que a capacidade de suportar está, de alguma forma, associada às suas percepções de autonomia para realizar seus trabalhos no nível da tarefa. Esse fato pode suscitar considerações sobre a própria escolha da ocupação destes trabalhadores na medida em que a Familiaridade aponta para o processo de aproximação gradativa com o trabalho, possibilitado mediante a construção de um conhecimento especifico dos próprios trabalhadores.

Um aspecto interessante se refere à dimensão Familiaridade expressa no nível Intergrupal de representação que se apresenta com possibilidade de articulador destas estratégias de defesas. O trecho da resposta ao item que se 
refere à dimensão Familiaridade Interpessoal (Como é a sua comunicação com familiares e amigos quando está atuando na emergência) ilustra esse aspecto.

(S7) Claro, com o celular eu falo a hora que quiser, a não ser quando eu estou no meio do procedimento, mas normalmente meu filho, minha mulher me ligam e eu ligo pra eles. Se me mandam um whatsapp eu ligo em dez minutos. O telefone toca, já tem o toque personalizado, já sei se é família, cliente de consultório só pelo tipo do toque.

Ao desdobrar os indicadores por ocupação do Grande Grupo 2 do CBO, considerando a ocupação Médico, que está categorizada como nível máximo de responsabilidade, verifica-se que no nível de representação Societal há penosidade de alta intensidade nas três dimensões (Limite Subjetivo 3,0; Familiaridade 2,8; Poder 2,7). Estes resultados apontam para a hipótese de que estes sujeitos não utilizam estratégias de defesa ou, se utilizam, estas não são suficientes para as situações que envolvem o nível Societal. Na análise dos itens Limite Subjetivo Societal (Sobre qual a ideia que a sociedade tem sobre as situações que envolvem o serviço de saúde pública.), Familiaridade societal (Sobre o que a sociedade pensa sobre profissionais da emergência); e, Poder societal (Sobre a valorização e o reconhecimento de quem trabalha em emergência), os sujeitos de forma geral apresentaram ideias semelhantes aos trechos de respostas descritos a seguir.

(S201) Eu acho que hoje em dia a imagem tá muito deteriorada. Antigamente você tinha uma imagem do médico melhor, né? Era quase como um semi-deus, é claro que esse exagero também não é nada bom, mas hoje em dia eu acho que a imagem do médico, da saúde, está muito deteriorada, até mesmo porque você vê muitas deficiências em termos de recursos, e de hospitais, e tudo isso... Mas você tem profissionais muito bons, dedicados, que apesar de tudo continuam aí... Mas esses aí ficam também com a minoria, né? Não tem muita expressão. Mas sempre também quando aparece alguma coisa positiva (...) sempre aparece algumas notícias, mas as piores notícias, de denegrir, são muito mais quantidade, do que as notícias de valorizar, mas vira e mexe aparece, recentemente, ano passado, teve o nosso neurocirurgião que foi muito comentado o caso do vergalhão que atravessou, né? Teve também até um menino da P. que foi assaltado, tem uns dois ou três anos, vê se você se lembra, aí ele foi assaltado, foi baleado, foi assistido tudo por aqui, pela pediatria, pela neuro, e hoje em dia ele tá lá estudando na P. de novo... Aí isso aparece na mídia assim... Um pouco, né? Aí depois só críticas negativas... Mas aí, assim, a gente vai continuando, fazer o quê?

(S70) Eu acho que cada vez mais tem se pensando de maneira negativa. Eu acho que a primeira vez que um profissional da área de saúde, é... questionado e 
afrontado de maneira pública pelo governo, pelos governos. Essa é a minha opinião.

(S32) É engraçado, o pessoal diz assim: "a você trabalha lá na emergência, pô lá, aquilo é duro, é pesado né", mas logo depois: "há, isso é funcionário público.", então é um misto que todo mundo acha, que é pesado trabalhar na emergência, mas acho que já estão tão habituadas a falar mal, que na mesma hora de reconhecer que o trabalho aqui é pesado, logo depois, é... Olha com desprezo, raiva, seja lá o que for.

$\mathrm{Na}$ ocupação Enfermeiro, que está categorizada como nível altíssimo de responsabilidade na ocupação do Grande Grupo 2 do $\mathrm{CBO}$, verifica-se proximidade de resultados. O nível de representação Societal apresenta penosidade de maior intensidade na dimensão Limite Subjetivo (3,3). Estes resultados apontam para a hipótese de que estes sujeitos, também, não utilizam estratégias de defesa ou, se utilizam, estas não são suficientes para as situações que envolvem o nível Societal.

(S 54) Eu acho assim, veja, que eles tem muito uma visão hospitalar ainda, sabe? Que o SUS não funciona, que saúde pública não funciona, eles vêm muito com essa mentalidade. E quando a gente às vezes, não está no nosso protocolo, diz um não aqui na nossa emergência, pra acolher, eles veem isso como uma falta de cuidado, como uma falta de consideração com a situação deles. Mas não é que a gente está desmerecendo a dor... "Ah, eu tenho uma dor há dois meses no meu joelho", se fosse emergência, se fosse alguma fratura, alguma coisa, ele não teria esperado dois meses, mas a gente não está dizendo que a dor dele não é importante pra nós, a gente está dizendo que não é nosso protocolo. Por quê? Se abrir a porta pra esse paciente com dor há dois meses, amplifica o cuidado, Isso aqui vai estar cheio, vai ter fila aqui, como tinha antigamente. Ai o que acontece: chega um paciente grave, que realmente necessita de um cuidado e imediato, o médico vai estar estressado ou ocupado ou envolvido com esses outros pacientes que não cabem em emergência. Então é por isso que tem essa diferenciação. Não é que a gente não queira atender, não é que a gente não se preocupa com o cuidado, ou o médico ou a enfermagem, acho que a emergência tem meio esse conceito de... Ah, não se preocupa, não está se preocupando com minha dor, às vezes a gente abre aqui, alguém torce um pé, entrou, é protocolo, torce é. A gente sabe que quem torce dói bastante, dependendo do caso, então a gente deixa o paciente lá aguardando, às vezes a equipe está toda lá em cima no centro cirúrgico, ou em cima de algum paciente que está grave, porque eles não deixam o setor pra atender pouca coisa, pelo menos um fica, quando está a equipe toda é porque o negócio está feio. E eles, tipo, aqui embaixo, ficam "ah, porque é um descaso do médico, a gente fica esperando", nãnãnãnã, então pensa , às vezes é um paciente que tá precisando e ainda espera, imagina um que não precisa, imagina a fila que ia ter aqui. Entendeu?

Nas demais ocupações no GG2 do CBO, Assistente Social, Dentista, Fonoaudiólogo, Nutricionista, Psicólogo, categorizadas como nível alto de responsabilidade, novamente verifica-se semelhança de resultados, no que tange 
ao nível de representação Societal apresentando penosidade de alta intensidade, também na dimensão Limite Subjetivo $(2,7)$. Estes resultados apontam para a hipótese de que as estratégias de defesa não são suficientes para as situações que envolvem o nível Societal:

(S33) Bom, obviamente que é tanto atendimento que existem criticas também porque, cada familiar ele pensa no seu ente querido e aquele diretamente voltado a ele. Então o familiar esquece que as vezes existem outros que precisam ser também observados. Então ele só que a junta medica pra aquele paciente e se torna difícil. Existem criticas por causa disso, por que "ah, o paciente ficou largado", não o paciente não ficou largado, ele ficou em observação, pra ver a evolução do trauma, com vai ser e o organismo vai reagir. Então dependendo da reação vai ser dada medicação ou outra, o paciente vai ser reavaliado... outros exames. Então ele precisa desse tempo e as vezes a família acha que o paciente está largado e não pensa muito que esse tempo é importante, né. E outra coisa é que às vezes o paciente fica nervoso querendo ver a evolução do seu caso rápido e nem sempre isso é possível. Então existe sempre esse nervosismo do ente querido, do acidentado em emergência. Eles puxam muito do medico em relação a isso, pra ver o seu ente querido.

Diferente da penosidade do Enfermeiro, a de Técnico de Enfermagem, incluída com grau médio/alto de responsabilidade no GG3 do CBO, apresenta sofrimento psíquico equilibrado entre as dimensões e níveis de representação, com seu índice mais elevado em Poder interpessoal (Como é a representação no que se refere à autonomia no nível da tarefa), $(2,3)$, o que indica que não há utilização de estratégias defensivas neste fator.

(S173) Aqui a gente não se posiciona. Por que tipo assim, notícia ruim e essas coisas, quem tem q comunicar é o médico. Por que vai que alguém passe mal aí quem foi que deu a notícia? "Ah foi a técnica de enfermagem", então a gente não tem autonomia pra isso, quem tem que dar é o médico, porque ele que opera ele que sabe as condições do paciente.

Nas demais ocupações no GG3 do CBO, Instrumentista cirúrgico, Técnico gessista, Técnico em radiologia e Secretária, categorizadas como nível médio de responsabilidade, os resultados também se assemelham em níveis de representação. Quanto ao nível de representação Societal apresentam penosidade de alta intensidade nas dimensões Familiaridade $(3,4)$ e Limite Subjetivo $(3,3)$. Estes resultados apontam para a hipótese de que as estratégias de defesa não são suficientes. 
(S45) Olha, infelizmente no geral, eu posso tirar isso porque eu já presenciei isso, as pessoas julgam muito mal o servidor público, porque infelizmente vem uma mentalidade, já antiga, que o servidor público não faz nada, não quer nada, e ficou estigmatizado isso, realmente a gente vê que tem casos que a gente chega e há falta de atenção, falta de você ser solícito com uma pessoa que está passando mal, de você dar atenção, de você poder ajudar aquela pessoa, já passei por isso, de eu ser profissional da área e chegar numa unidade, e você vê todo mundo conversando, aquele descaso, e você está angustiado, está passando mal, e ninguém toma uma providência, você tem que muitas das vezes brigar, ou questionar, ou então bater de frente para você ser bem atendido. Mas eu acho que hoje em dia, a demanda é muito grande, que o que acontece. Na minha opinião, as pessoas sofrem acidente na rua, tem plano de saúde, vem pra aqui pra dentro, faz o primeiro atendimento, são depois levados para uma clínica particular para, fazer o procedimento final, e quem pegou a primeira situação foi um hospital de emergência, que muitas das vezes não tem valor nenhum pra eles porque, já trabalhei em clínica particular, e você chega lá com todos os exames, e os médicos fazem você fazer tudo de novo, porque eles dizem: "ah... Não foi feito aqui"... Então assim, eu acho que emergência de todos os hospitais públicos, federais, municipais e estaduais, está um caos porque a gente não tem uma direção, nós cansamos de atender pacientes que nem do município do Rio é, porque vem de diversos hospitais que passam e não são atendidos, então assim, eu acho que a emergência está muito complicada, está estigmatizada. Então os funcionários foram rotulados como medíocres, como que não querem nada, porque tem estabilidade... e não é bem por aí, porque a gente sabe que as coisas não funcionam dessa forma né.

(S37) A sociedade em si, você tem visto pela reportagem o que você está falando. Alguns estão satisfeitos, mas a maioria está insatisfeita, com a maneira do tratamento, que não é legal, entendeu? Uma indiferença, não dá um total apoio pro doente, é a hora que ele mais precisa, quando a pessoa está doente, ele volta a ser criança entendeu?, Conversar com o paciente, falar o que ele tem entendeu? Dar uma força maior pra ele, conversar com os familiares, ter uma comunicação com os pacientes em si, e aqui eles não tem isso.

Nas ocupações sem código, Acadêmico e Estagiário; o nível Societal também aparece como importante nos resultados. O resultado maior, para estagiários e acadêmicos, está na dimensão Limite Subjetivo $(2,7)$.

(S78) Ah, eu... Eu não sei, é... Por que eu tenho muito... na minha visão, é muito difícil eu conseguir saber exatamente o que as outras pessoas pensam, mas eu acho que... Não sei... E... Muitas vezes, como tipo: "Será que vai salvar naquela situação". Sabe, aquela situação de muitas vezes, de vida ou morte...Vai conseguir, realmente salvar alguém e às vezes pode acabar sendo... Meio demonizado por alguma conduta errada, sabe... Mas... é uma área muito difícil, que ao mesmo tempo você consegue ser... Idolatrado e por outro lado... Demonizado. em muita gente que critica muito. Como os hospitais públicos estão hoje em dia, sabe? Mas eu vejo que... assim, eu acho que a sociedade tem uma péssima visão, mas quando você tá dentro, você acaba mudando um pouco de ideia, por que você vê o como, como aqueles profissionais trabalham, como eles estão empenhados em te ajudar. Então acho que é uma visão que só é de fora... Quando você vive que ela acaba mudando. 
Quando desdobramos os resultados para analisar o nível de responsabilidade alto no que se refere aos setores, Centro cirúrgico, Sala vermelha e Sala amarela, os indicadores de maior intensidade estão nos níveis de representação Societal nas dimensões Familiaridade $(2,6)$ e Limite Subjetivo $(2,6)$.

(S56) No Brasil a gente é desvalorizado, eu acho. É, em outros países o profissional de emergência é na verdade aquele mais qualificado. No Brasil na verdade quem entra pra fazer emergência é quem acabou de se formar então a gente é menos valorizado do que um profissional que faça consultório ás vezes.

(S144) Eu acho que a sociedade não tem muita ideia de funcionamento do sistema de saúde e do gerenciamento de cuidados. Eu acho que o grande problema do nosso sistema de saúde, e ai entra todas as classes, todas as camadas da sociedade que não tem essa formação bem estabelecida e bem divulgada por fora pelo menos do meio médico que não entende o trâmite, como isso funciona, como é que funciona esse cuidado, como é que tem que ser a busca por esse cuidado, da onde começa, os níveis que devem ser seguidos, exatamente para ter esse atendimento que todo mundo reclama que a emergência esta vazia, mas é porque nem sempre o paciente tem que buscar emergência. Então, fica lotada. A emergência esta sempre sobrecarregada porque ela não é escoada. Então essa necessidade de cuidados é ideia básica: "ah, eu vou pro hospital e tenho que ser cuidado", mas ele não sabe que segmento do hospital tem que ser procurado. Essa educação não existe.

No que se refere aos turnos de trabalho, os resultados demonstram que o sofrimento psíquico afeta com maior intensidade aqueles sujeitos que atuam no turno noturno no nível de representação Societal Limite Subjetivo $(4,0)$ resultado apresentado com um grau próximo do insuportável. Cabe colocar mais uma vez a necessidade de trabalho no que se refere à utilização de estratégias de defesa.

(S23) O pessoal tem aquela ligeira impressão que enfermeira é comida de médico, que só está aqui pra se prostituir né? Trabalhar no turno noturno é complicado. Porque antigamente a enfermagem nada mais era do que isso, se você for ver a história de Florence Nightingale, as mulheres enfermeiras eram prostitutas, que ficavam na guerra pra ajudar. Lê a história dela pra você ver, é mais ou menos assim. Tem gente que vem trabalhar a noite pra ser caso de médico, e não é bem assim, a gente vem pra... por mim que eu estou falando, eu venho porque eu gosto , eu gosto de trabalhar no centro cirúrgico, de trabalhar na área do centro cirúrgico. Mas, o turno noturno é complicado assim porque tem muita gente que tem esse preconceito que a gente é... Ainda mais quando a gente é casada. Quando eu era recém-casada uns colegas do meu marido falavam, "ué você deixa sua mulher trabalhar à noite?" Aí ele: "ué, mas eu confio nela". Você ouve uns comentários assim, que você fica: Aham... Será? A pessoa tá falando isso mesmo?

No que tange à escala de trabalho, com os indicadores desdobrados em dimensões e níveis de representação, verifica-se que no nível Societal há 
penosidade de mais alta intensidade na dimensão Familiaridade $(3,7)$ e Poder $(3,6)$ naqueles funcionários que atuam em dupla matrícula, ou seja, além de seu trabalho diário, também atuam em plantões.

(S84) Olha, de uma manera geral, eu acho que as pessoas conhecem muito superficialmente o trabalho que a gente faz, entendeu? Esse trabalho da emergência, na realidade, é um trabalho fundamental, né? O número de pacientes que são atendidos aqui... as pessoas não têm noção do número de atendimentos que é feito aqui na emergência, na quantidade de trauma que existe, queda de moto que a gente vê quase todo dia. Os acidentados, por exemplo, na praia, que às vezes uma simples onda no mar causa uma lesão de coluna, ou até um afogado mesmo. O serviço de emergência tá aí pra... É fundamental, é a certeza de você poder procurar um lugar, né?, com qualquer tipo de problema que você precisa resolver naquele dia, né?, desde um problema ocular, uma simples conjuntivite e tal, até um problema mais grave, de repente um aneurisma cerebral ou alguma coisa assim, é bom você saber que você tem um ponto de referência que chegando lá os colegas são colegas bem preparados pra resolver o seu problema. Mas eu acho que a população em geral não tem essa noção, talvez, até da importância do hospital.

(S55) A valorização e o reconhecimento ainda estão aquém do que deveriam entendeu, tanto em termos de remuneração, como em termos ainda de, sabe de, resgate desse valor junto a mídia né, de valorizar a imagem o profissional, nos órgão de imprensa, isso ainda esta muito aquém do que deveria.

Quanto à faixa etária, os índices mais altos referem-se à faixa etária 41-50 anos, nos níveis de representação por dimensão; Societal Limite Subjetivo $(3,0)$

(S77) Acho meio complexo... acho complexo, porque, o pessoal de fato acha assim, que a gente não trabalha muito bem, sempre tem uma reclamação de uma coisa ou outra, sempre reclama de uma coisa ou outra, não acho muito boa

Quanto ao tempo na ocupação, tempo na emergência; tempo no Hospital Municipal Miguel Couto; e, tempo na emergência do Hospital Municipal Miguel Couto, a faixa 11 ou mais apresentou maior penosidade no Limite Subjetivo $(2,9)$.

(S77) Acho meio complexo, acho complexo, porque, o pessoal de fato acha assim, que a gente não trabalha muito bem, sempre tem uma reclamação de uma coisa ou outra, sempre reclama de uma coisa ou outra, não acho muito boa.

O que se articula com a Psicodinâmica do Trabalho a partir destas representações dos funcionários que atuam na emergência é sobretudo a ideia sobre as estratégias defensivas coletivas como mediadoras entre carga psíquica e 
organização do trabalho. Para Dejours (2015), o trabalhador é, “despossuído de seu corpo físico e nervoso, domesticado e forçado a agir conforme a vontade do outro (...) mas, vemos que a inatividade na organização de trabalho, entrava a descarga pulsional e pode ocasionar verdadeira inflação da carga psíquica.” (p. 26).

A carga pulsional acumulada no aparelho psíquico, porque não houve descarga no exercício do trabalho, causa sentimento de desprazer e tensão, e a carga psíquica aumenta, podendo ocasionar fadiga e astenia, o que leva à patologia trabalho fatigante. Se, de outro lado, se o trabalho permite a diminuição da carga psíquica, propicia o equilíbrio. A representação de autonomia em relação ao trabalho (dimensão Poder) quando percebida positivamente, é um dos vetores importantes para a descarga de energia psíquica e promove o trabalho equilibrante. Conforme Dejours (1994) descreve:

Um trabalho livremente escolhido ou livremente organizado oferece, geralmente, vias de descarga mais adaptadas às necessidades: o trabalho torna-se então um meio de relaxamento, às vezes a um tal ponto que uma vez a tarefa terminada, o trabalhador se sente melhor que antes de tê-lo começado (p.25)

Para possibilitar a diminuição da penosidade nos profissionais que atuam na emergência do hospital público, alvo do diagnóstico obtido com o Inventário de Avaliação da Penosidade - IAP, tanto na dimensão Poder quanto na dimensão Limite Subjetivo, as intervenções advêm da implantação de estratégias de defesa coletiva.

Tanto Dejours (1994) quanto Moscovici e Doise (1991) oferecem discussões relevantes para o entendimento do conceito. Moscovici e Doise formularam uma teoria sobre o trabalho de decisão no contexto de dissensões e consenso, em que descrevem a transformação das representações individuais para a representação social. Dejours (1994) conceitua estratégia defensiva coletiva no interior da teoria da Psicodinâmica do trabalho.

Moscovici e Doise (1991) apontam que, para a busca do consenso é preciso encontrar a base comum dos argumentos apresentados pelos indivíduos. 
pessoas que no início não se conhecem encontram sempre um núcleo de noções ou significados que conduzem a uma tal visão. (...) A partir do momento que surge uma suspeita diferindo, todos os meios intelectuais e afectivos intervêm, a fim de inventar argumentos, interpretar os pontos de vista opostos, encontrar a razão do desacordo, e, sobretudo, a saída para ele. (...) O significado em relação à decisão a tomar é clarificado, as dimensões pertinentes mais salientes aparecem mais uniformes aos olhos dos participantes. Isto significa que a comunicação sintonizouos, organizando os elementos de informação numa visão comum, tanto mais unificada quanto nela se participa mais ativamente. (p. 208)

Sendo assim, as representações individuais, antes distintas, transformam-se em representação partilhada.

Considerando que as estratégias defensivas transformam as representações que os trabalhadores têm da realidade e, o paradoxo entre sofrimento individual e estratégia defensiva coletiva, Dejours (1994) aponta que, embora prazer e sofrimento sejam vivências subjetivas, as estratégias defensivas funcionam como regras.

Como toda regra, ela (a estratégia defensiva) supõe um consenso ou um acordo partilhado. Um tal acordo normativo, quando ele existe, não implica uma coisificação de um sujeito submetido à regra. (...) a diferença fundamental entre um mecanismo de defesa individual e uma estratégia coletiva de defesa é que o mecanismo de defesa está interiorizado (no sentido psicanalítico do termo), ou seja, ele persiste mesmo sem a presença física de outros, enquanto a estratégia coletiva de defesa não se sustenta a não ser por um consenso, dependendo assim, de condições externas.(p. 128/129)

Para Dejours (1994) tanto quanto as estratégias coletivas de defesa têm impacto no funcionamento psíquico do indivíduo, também têm no funcionamento coletivo. Para ele, "as estratégias de defesa coletiva têm um papel essencial na própria estruturação dos coletivos de trabalho, na sua coesão e estabilização". (p. 130).

$\mathrm{Na}$ prática cotidiana das organizações é preciso aplicar estes conceitos implantando intervenções. E sobre esta possibilidade de aplicabilidade, com base nas informações diagnósticas descritas é possível definir diretrizes e metas com vistas a minimização do sofrimento psíquico dos trabalhadores. Estas diretrizes e metas, desdobradas em planos de ação, garantem o efetivo controle e melhoria dos processos de gestão.

O sistema Lean Six Sigma é uma metodologia que foi criada na década de 1980, por Bill Smith da Motorola, com o objetivo de aumentar a eficácia em processos a partir da confiabilidade de suas análises diagnósticas e, sobretudo por 
sua capacidade de estabelecer planos de ação consistentes com a necessidade de melhoria. Inicialmente foi concebido para medir defeitos e melhorar a qualidade global de processos utilizando análises estatísticas. Entretanto, a metodologia Six Sigma (seis níveis de qualidade de processos) tem sido utilizada de diferentes maneiras, incluindo aquelas relacionadas à interação humana. Esta metodologia utiliza o sistema DMAIC (define, measure, analyse, improve e control = DEFINIR - Qual o problema?; MEDIR/mensurar - Qual o impacto para a organização?; ANALISAR - Por que acontece?; APRIMORAR/melhorar - Como fazer para evitar que aconteça?; CONTROLAR - Como manter o novo jeito de fazer?) para melhorar projetos já implantados que apresentam resultados insuficientes em termos de qualidade.

É possível associar esta metodologia Six Sigma à prevenção e promoção de saúde e, especificamente, no âmbito da penosidade. Assim, com base no diagnóstico, alvo desta tese de doutorado, as intervenções tem melhor eficácia, na medida em que são fornecidas as informações detalhadas no que se referem ás dimensões e níveis de representação com os maiores índices de penosidade.

Aplicando-se o DMAIC, a definição do problema - D, os resultados que apresentaram os maiores índices de penosidade - nível de representação Societal, sobretudo nas dimensões Limite Subjetivo e Poder. A mensuração do problema - M são os índices especificados por cada grupo de ocupações e por setores de alocação. A identificação de suas causas - A e impactos no cotidiano da gestão de cuidado, podem ser identificados a partir de uma matriz de esforço e impacto (FIGURA 3) que permite a elaboração de planos de ação com intervenções para a melhoria do fenômeno - I. Sendo assim, a área responsável na instituição pode garantir instrumentos capazes de controlar - C, os resultados após a implantação de intervenções. 
Figura 3 - Matriz de Esforço-Impacto para tomada de decisões

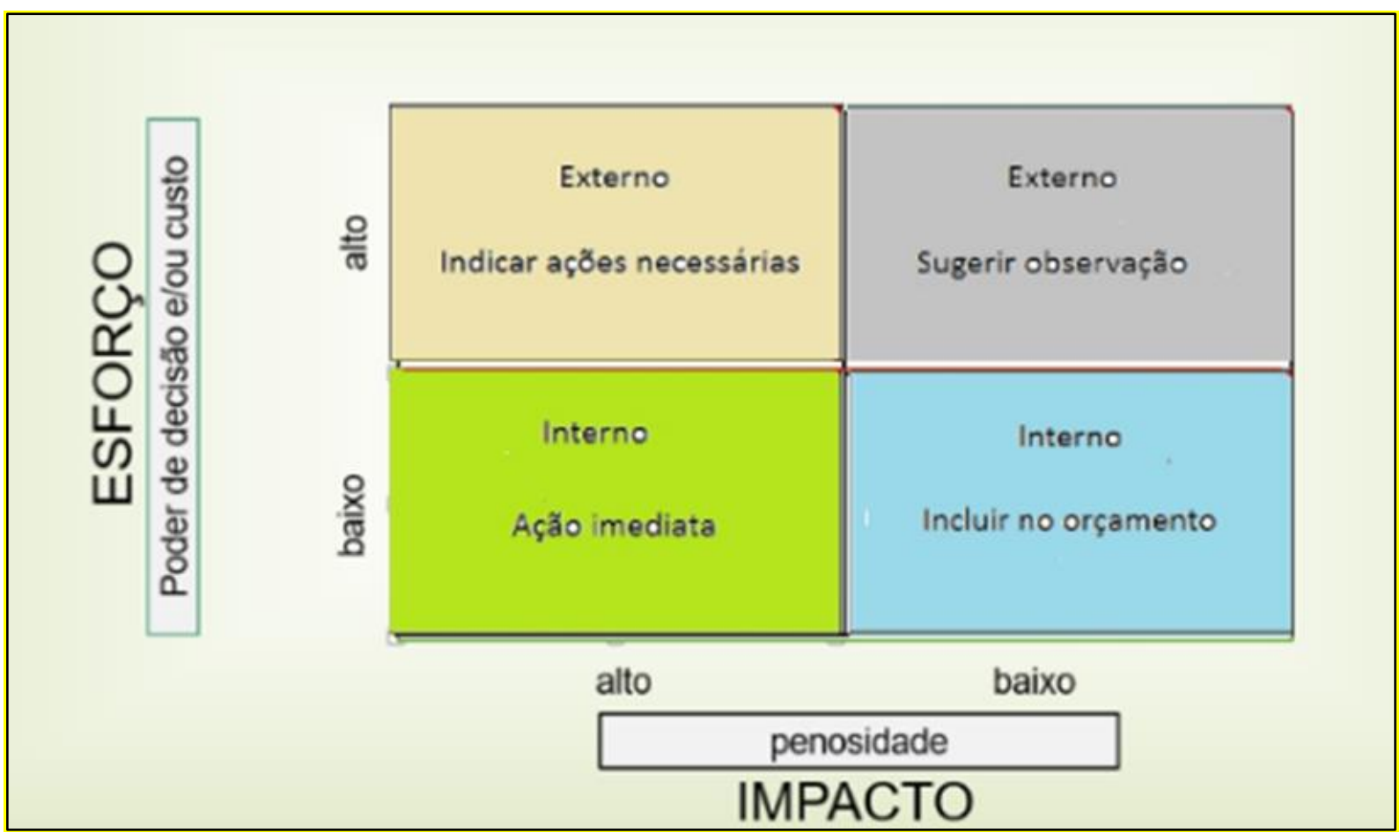

No Hospital Municipal Miguel Couto, embora não fosse o objetivo da pesquisa, foram realizadas reuniões com cinco responsáveis pela área de emergência com o objetivo de planejar intervenções com base no diagnóstico realizado durante o período da realização da pesquisa. Foram sugeridas intervenções que priorizam estratégias de defesa coletiva, tais como: grupos de reflexão, programas de desenvolvimento de habilidades interpessoais, treinamento de assertividade; criação de projeto de revisão, difusão e aplicação de protocolos e procedimentos padrão (realizados, diretamente pelo hospital); campanha na mídia sobre gestão do cuidado em emergência (pelo Ministério da Saúde e/ou Secretaria Municipal de Saúde). .Todas as sugestões foram descritas no relatório de conclusão da pesquisa e enviadas para o Ministério da Saúde. 


\section{Conclusão}

Esta tese de doutorado, sobre sofrimento psíquico relacionado ao trabalho, objetivou construir um instrumento que possibilite avaliar a penosidade com indicadores mensuráveis quantitativos, extraídos de análise qualitativa das representações de trabalhadores.

Para compreender o mundo do trabalho e sua relação com a subjetividade humana discutiu-se a realidade do mundo do trabalho brasileiro (MINISTÉRIO DO TRABALHO E EMPREGO - MET, 2017; SANTOS, 2012; BIONDI, 2009), a partir do conceito de vita activa (ARENDT, 1991). A ideia foi demonstrar que, embora bem sistematizado como desdobramento do preconizado pela Organização Internacional do Trabalho - OIT, o sistema hierarquizado por níveis de competência, não apresenta o correlato no que tange à proteção integral da pessoa humana. A ênfase está no corpo para o trabalho como se destituído de alma. Defende-se, portanto, que é necessário o estudo do corpo no trabalho considerado na visão monista, corpo/mente. Para esta proteção, entendida como prevenção e promoção de saúde, é necessário que a qualidade diagnóstica do fenômeno forneça informações específicas das demandas laborais.

Para estudar esta realidade brasileira de forma analítica inseriu-se uma discussão da realidade mundial, priorizando-se as visões de Chomsky (2017) em sua recente publicação "Quem manda no mundo" e de George (2010; 2013) em seu trabalho sobre os Relatórios Lugano I e II, de forma articulada com a visão de outros pensadores (HOBSBAWM, 1997; JAGUARIBE, 1987; OLIVEIRA VIANNA, 1974; PENNA, 1989; SOARES, 2004; VOVELLE, 1987; WAGNER, 2002; WALLERSTEIN, 1998).

O constructo teórico, fundamento desta tese, está composto pela Psicodinâmica do Trabalho e pela Teoria das Representações Sociais, do qual foram extraídos os indicadores, expressos em dimensões e níveis. (DEJOURS, C., 2005, 1998, 1994, 1993, SATO, 1999; MENDES, 2002; Silva, 2015; DOISE, 2002; MOSCOVICI \& DOISE, 1991; MOSCOVICI, 1990, 1978, 2003; WAGNER, 1998; ALMEIDA, 1999; BOTELLA \& BOTELLA, 2002; SILVA, 2017). 
Os estudos sobre burnout (MASLACH, C \& JACKSON, 1981; Silva et al, 2015) foi tratado de forma articulada com o conceito de estratégias defensivas na visão de Dejours sobre a banalização da injustiça social (1992, 1993, 1994, 2005) que analisa as estratégias defensivas coletivas além das individuais.

Partindo do pressuposto de que a realidade é construída dialeticamente e considerando-se a visão de Homem e de mundo pautada na interação sujeito/objeto, aponta-se a relação entre representações e subjetividade, fundamentada numa discussão que remete ao aforismo socrático "Por que existe alguma coisa ao invés do nada" (GARCIA-ROZA, 1991, 1985; KOYRÉ, 1991; GUITTON; BOGDANOV; BOGDANOV, 1993; FREUD, 1932, 1900; GONDAR, 1995; BOTELLA; BOTELLA, 2002; MOSCOVICI, 1990)

Buscando a compreensão de como o conceito de representações sociais permite informações diagnósticas fundamentais na medida em que "as práticas de conhecimento e do conhecimento prático desempenham um papel essencial, estudou-se a forma com a qual estas práticas inscrevem-se "nas experiências ou acontecimentos sustentados por indivíduos e partilhados pela sociedade." (MOSCOVICI, 2003, p. 217). Foi fundamental a contribuição de Wagner (1998) sobre as características 'holomórficas' de uma representação.

Com esta fundamentação construiu-se o Instrumento de Avaliação da Penosidade - IAP, considerando-se como itens do protocolo de entrevista, as dimensões, Familiaridade, Poder e Limite Subjetivo extraídas da Psicodinâmica do Trabalho (DEJOURS, C., 2005, 1998, 1994, 1993; SATO, 1999) integradas aos níveis de representação, Intraindividual, Interpessoal, Intergrupal e societal, inspirados na Teoria das Representações Sociais, em sua abordagem societal (DOISE, 2002; MOSCOVICI \& DOISE, 1991; MOSCOVICI, 1990, 1978, 2003; WAGNER, 1998; ALMEIDA, 1999)

Para verificar a qualidade psicométrica do instrumento (BROWN, 2006; HATCHER, 1994; HAYTON, ALLEN, SCARPELLO, 2004; MATSUNAGA 2010; TABACHNICK B, FIDELL L, 2001). , considerou-se a fidedignidade como uma das propriedades mais elementares de um instrumento, foi utilizado um parâmetro consagrado na literatura. Trata-se do Alfa de Cronbach. Além disso, foi realizada a Análise de Itens em relação a todos os itens que compõem a Escala. Neste caso, pode-se calcular a Correlação Item Total de cada um dos itens. Para a avaliação da validade de constructo foi realizada a Análise Fatorial Exploratória 
(Data Driven) para verificar até que ponto todos os itens que compõem o instrumento se constituem como Fatores que explicam os dados produzidos por este instrumento. Além do Alfa de Cronbach, foram utilizados o índice de KaiserMeyer-Olkin - KMO, o método de extração axis factoring, o scree plot e os eigenvalues. Os resultados desta análise mostraram que o instrumento apresenta consistência interna razoável (alpha de Cronbach $\alpha=.68$ ), com correlação item total moderada ( $\mathrm{r}=32$ ) (GEORGE \& MALLERY, 2003). Na análise fatorial verificou-se poder Intraindividual apresentou comunalidade baixa (.08). Pela análise do scree plot e dos eigenvalues a melhor estruturação é a de 3 fatores que respondem por $42.5 \%$ da variância. (BROWN, 2006; HATCHER, 1994). A solução de três fatores apresentou uma estrutura bem definida. Sugere-se a continuidade de pesquisas sobre a dimensão Poder articulada com o nível de representação Intraindividual, para aprimoramento do instrumento.

Quanto ao diagnóstico do trabalho de pessoas que atuam em emergência de hospital público no Município do Rio de Janeiro, os resultados originados da coleta de dados em 249 sujeitos que trabalham na emergência do Hospital Municipal Miguel Couto (GRÁFICOS de 6 à 44), apontaram para a constatação de que, independente da dimensão de análise representações sociais de sofrimento psíquico em relação ao trabalho estão prioritariamente nos níveis Societal e Interpessoal. Considerando-se que são os sistemas de interação individuais que fornecem os princípios explicativos típicos das dinâmicas do nível Interpessoal e, que o nível Societal analisa os sistemas de crenças, representações, avaliações e normas sociais foi possível sugerir intervenções que apontam para a diminuição do sofrimento psíquico destes trabalhadores.

Sendo assim completam-se os objetivos desta tese se doutorado em relação à construção e validação do instrumento para diagnóstico do sofrimento psíquico relacionado ao trabalho, definindo indicadores mensuráveis de penosidade com base nas dimensões descritas na Psicodinâmica do Trabalho e nos níveis de representações propostos na Abordagem Societal das Representações; verificando a qualidade psicométrica do instrumento, denominado Inventário de Avaliação de Penosidade - IAP, e investigando as representações sociais de sofrimento psíquico em relação ao trabalho. 


\section{Referências bibliográficas}

Almeida, Angela Maria de Oliveira. (2009). Abordagem societal das representações sociais. Sociedade e Estado, 24(3), 713-737. https://dx.doi.org/10.1590/S0102-69922009000300005

Arendt, Hannah. A condição humana. Rio de Janeiro: Forense universitária, 1991.

Biondi, Luigi (2009) A Greve Geral de 1917 em São Paulo e a imigração italiana: novas perspectivas. Cad. AEL, v.15, $\mathrm{n}$ 27: https://www.ifch.unicamp.br/ojs/index.php/ael/article/view/2577/1987.

Botella, Cesar; Botella, Sara (2002) Irrepresentável: mais além da representação. Sociedade de Psicologia do Rio Grande do Sul/ Criação Humana, 2002: https://psicanalisedownload.files.wordpress.com/2012/08/resen_psy141.

Brown Timoty A. (2006) Confirmatory factor analysis for applied research. New York: Guilford Press;

Chomsky, Noam (2017). Quem manda no mundo. São Paulo: Planeta..

Comissão da verdade do Estado de São Paulo (2013). Mortos e Desaparecidos: Aurora Maria Nascimento Furtado: http://comissaodaverdade.al.sp.gov.br/mortos-desaparecidos/aurora-marianascimento-furtado.

Comissão da verdade do Estado do Rio de Janeiro (2014). Advogados de Presos e Perseguidos Políticos $(O A B / R J)$ : Eny Moreira: https://www.youtube.com/watch?v=BRp9FrTA9k4

Costello, Anna B. \& Jason Osborne (2005). Best practices in exploratory factor analysis: four recommendations for getting the most from your analysis. Practical Assessment Research \& Evaluation, 10(7): http://pareonline.net/getvn.asp?v=10\&n=7

Damásio, Bruno Figueiredo. (2012). Uso da análise fatorial exploratória em psicologia. Avaliação Psicológica, 11(2), 213-228. Recuperado em 27 de janeiro de 2019, de http://pepsic.bvsalud.org/scielo.php?script=sci_arttext\&pid=S167704712012000200007\&lng=pt\&tlng=pt.

Dejours, Christophe (2005). A banalização da injustiça social. Rio de Janeiro: FGV.

Dejours, Christophe (2015). A loucura do trabalho: estudo de Psicopatologia do Trabalho. São Paulo: Cortez, 2015.

Dejours, Christophe (1994). Psicodinâmica do trabalho: contribuições da escola dejouriana à análise da relação prazer, sofrimento trabalho. São Paulo: Atlas. 
Dejours, Christophe (1993). Uma nova visão do sofrimento humano nas organizações: $O$ indivíduo na organização: dimensões esquecidas. São Paulo: Atlas.

Doise, Willem. (2002). Da psicologia social à psicologia societal. Psicologia: Teoria e Pesquisa, 18(1), 027-035. https://dx.doi.org/10.1590/S0102$\underline{37722002000100004}$

Freud, Sigmund (sd1900/1973) Obras completes de Sigmund Freud, Interpretação dos sonhos, Tomo II, Psicologia dos processos oníricos, volume 4. Rio de Janeiro: Delta.

Freud, Sigmund (sd1932/1973) Obras completes de Sigmund Freud, Novas contribuições à psicanálise. Uma concepção do universo (XXXV), volume 17. Rio de Janeiro: Delta.

Freud, Sigmund (sd1925/1973) Obras completes de Sigmund Freud, Inibição, sintoma e angústia(XXXV), volume 9. Rio de Janeiro: Delta.

Garcia-Roza, Luis. Alfredo (1987). Freud e o inconsciente. Rio de Janeiro: Zahar.

Garcia-Roza, Luis. Alfredo (1981). Introdução à metapsicologia Freudiana, volume 1: sobre as afasias (1891): O projeto de 1895. Rio de Janeiro: Zahar.

George Dareen, Mallery Paul (2003). SPSS for Windows step by step: a simple guide and reference, 11.0 update. Boston: $\mathrm{A} \& \mathrm{~B}$.

George, Susan (2010). Informe Lugano : A preservação do capitalismo no século XXI. Barcelona: Icaria.

George, Susan (2013). El Informe Lugano II: Esta vez, vamos a liquidar la democracia. Barcelona: Planeta

Gondar, Jo (1995). Os tempos de Freud. Rio de Janeiro: Revinter.

Guimarães, Liliana Andolpho Magalhães, \& Rimoli, Adriana Odalia. (2006). "Mobbing" (assédio psicológico) no trabalho: uma síndrome psicossocial multidimensional. Psicologia: Teoria e Pesquisa, 22(2), 183-191. https://dx.doi.org/10.1590/S0102-37722006000200008

Guitton, Jean.; Bogdanov, Grishka.; Bogdanov, Igor (1993). Deus e a ciência. Rio de Janeiro: Nova Fronteira.

Hayton James, Allen David, Scarpello Vida (2004). Factor retention decisions in exploratory factor analysis: a tutorial on parallel analysis. Organ Res Meth. Apr 7.

Hobsbawm, Eric J. (1995). Era dos extremos: o breve século XX: 1914-1991. São Paulo: Companhia das Letras. 
Instituto Nacional de Metrologia, Qualidade e Tecnologia-Inmetro. Compreendendo a responsabilidade social: ISO 26000 e ABNT NBR 16001.:http://www.inmetro.gov.br/qualidade/responsabilidade_social.

Jaguaribe, Hélio e outros (1986). Brasil, sociedade democrática. Rio de Janeiro, José Olímpio.

Kerscher, Maracy Alves (1990). A representação social de república no exército brasileiro. Dissertação de mestrado. Rio de Janeiro: Fundação Getúlio Vargas.

Koyré, Alexandre (1991). Estudos de história do pensamento científico. Rio de Janeiro: Forense Universitária.

Krein, José Darin (2018). O desmonte dos direitos, as novas configurações do trabalho e o esvaziamento da ação coletiva. Consequências da reforma trabalhista. Tempo Social, revista de sociologia da USP, v.30, n1. Abril, p. 77 -104. https://www.revistas.usp.br/ts/article/view/138082.

Laplanche, Jean (2001). Vocabulário da Psicanálise. São Paulo: Martins Fontes.

Maslach, Christina and Jackson, Susan E. (1981). The measurement of experienced burnout. Journal of occupational behaviour, Vol. 2, 99-113. : https://onlinelibrary.wiley.com/doi/abs/10.1002/job.4030020205

Matsunaga Masaki (2010). How to Factor-Analyze Your Data Right: Do's, Don'ts, and How-To's. Int J Psychol Res.; 3(1), 97-110: https://www.redalyc.org/pdf/2990/299023509007.

Mendes, René (2002) Debate sobre o artigo de Leny Sato. Cadernos de Saúde Pública, Rio de Janeiro, v. 18, n. 5, Oct.: http://www.scielo.br/scielo.php?script=sci_arttext\&pid=S0102$\underline{311 X 2002000500007 \& \operatorname{lng}=e n \& n r m=i s o}$

Ministério do Trabalho e Emprego - MET. Classificação Brasileira de Ocupações-CBO:

http://www.mtecbo.gov.br/cbosite/pages/informacoesGerais.jsf, acesso em 05/07/2017.

Moscovici, Serge e Doise, Willem (1991). Dissensões e consenso: Uma teoria geral das decisões colectivas. Lisboa: Horizonte

Moscovici, Serge (1990). A máquina de fazer deuses. Rio de Janeiro: Imago.

Moscovici, Serge (1978). Representação social da psicanálise. Rio de Janeiro: Zahar.

Moscovici, Serge (2003). Representações sociais: investigações em psicologia social. Editado em inglês por Gerard Duveen; traduzido do inglês por Pedrinho A. Guareschi. Petrópolis: Vozes. 
Oliveira Vianna (1974) Instituições políticas brasileiras. Volume I. Rio de Janeiro: Record.

O'Rourke, Norm and Hatcher, Larry. (1994). A step-by step approach to using the SAS system for factor analysis and structural equation modeling. Cary: SAS Institute Inc.

Penna, Lincoln de Abreu (1989). Uma história da República. Rio de Janeiro: Nova Fronteira.

Richardson, A.; Kamenetz, F.; Stein, H.; Domiciano, I. (2016) Projeto Raposos Sustentável: análise dos discursos explicitado e pronunciados reservadamente. Manuscrito não publicado.

Rocha, Zeferino. (2011). A dor física e psíquica na metapsicologia freudiana. Rev. Mal Estar e Subjetividade, 11(2), 591-621. http://pepsic.bvsalud.org/scielo.php?script=sci arttext\&pid=S1518-

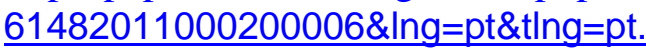

Santos, Adolfo Roberto Moreira (2012) O ministério do trabalho e emprego e a saúde no trabalho. In: Chagas, Ana Maria de Resende.; Salim, Celso Amorim; Servo, Luciana Mendes Santos (org.), Saúde e segurança no trabalho no Brasil: aspectos institucionais (pp. 21-75). São Paulo: IPEA/Fundacentro: http://www.ipea.gov.br/portal/images/stories/PDFs/livros/livros/livro_sauden otrabalho.pdf

Sarti, Cynthia A. (2008). Famílias enredadas In: Acosta, Ana Rojas; Vitale, Maria Amália Faller (Org.) (2008). Famílias: redes, laços e políticas públicas. 4 ed. São Paulo: Cortez/Instituto de Estudos Especiais/PUC-SP: http://www.bibliotecadigital.abong.org.br/handle/11465/1731

Sato, Leny. (1999). Representação social de trabalho penoso. In Spink, Mary Jane (Org.). $O$ conhecimento no cotidiano - As representações sociais na perspectiva da psicologia social. São Paulo: Brasiliense.

Silva, Deonísio da (2014). De onde vêm as palavras. Rio de Janeiro: Lexikon.

Silva, Renata Pimentel da, Barbosa, Silvânia da Cruz, Silva, Sandra Souza da, \& Patrício, Danielle Figueiredo. (2015). Burnout e estratégias de enfrentamento em profissionais de enfermagem. Arquivos Brasileiros de Psicologia, 67(1), 130-145: http://pepsic.bvsalud.org/scielo.php?script=sci_arttext\&pid=S180952672015000100010\&lng=pt\&tlng=pt

Soares, Gianna Maria de Paula. (2004). Responsabilidade social corporativa: por uma boa causa!?. RAE eletrônica, 3(2)https://dx.doi.org/10.1590/S1676$\underline{56482004000200007}$

Tabachnick Barbara, Fidell Linda S. (2001) Using Multivariate Statistics. 4th ed. Pearson. 


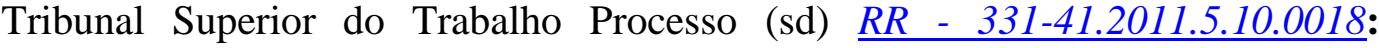
http://www.tst.jus.br/noticias/-/asset_publisher/89Dk/content/discriminacaogera-indenizacao-a-empregada-do-carrefour-em-brasilia

Vovelle, Michel (1987). Ideologias e mentalidades. São Paulo: Brasiliense.

Wagner, Eugenia Sales. (2002) Hannah Arendt e Karl Marx: o mundo do trabalho. Cotia: Atelier Editorial.

Wagner, Wolfgang. Sociogênese e características das representações sociais. In Moreira, Antonia Silva Paredes. e Oliveira, Denise Cristina. de (org.) Estudos interdisciplinares de representação social. Goiânia: AB, 1998, p. 3-25.

Wagner, Wolfgang. Social representations and beyond: brute facts, symbolic coping and domesticated worlds. Culture \& Psychology, 4, 1998, p. 297-329.

Wallerstein, Immanuel (1988). O fim do mundo tal como o concebemos: ciência social para o século XXI. Rio de Janeiro: Revan. 


\section{TERMO DE CONSENTIMENTO LIVRE E ESCLARECIDO}

\section{DADOS DE IDENTIFICAÇÃO DO PARTICIPANTE DA PESQUISA}

Nome:

Sexo: Masculino ( ) Feminino ( ) Data Nascimento:

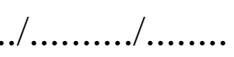

Endereço:

Bairro:

Cidade:

Telefone: (.....)...... Email:

\section{Título do Protocolo de Pesquisa:}

"Dimensões Analíticas do Fluxo de Informação na Trajetória do Usuário no Sistema Hospitalar: Análise do trabalho humano com ênfase em levantamento de indicadores de penosidade (sofrimento psíquico) de profissionais de emergência hospitalar".

\section{Pesquisadora responsável:}

Maracy Domingues Alves - Professora do Departamento de Psicologia/PUC-Rio.

Avaliação do risco da pesquisa:

(X) Risco Mínimo ( ) Risco Médio ( ) Risco Baixo ( ) Risco Maior

\section{Objetivos e Justificativa:}

Como funcionário do Serviço de Emergência, você está sendo convidado a participar de pesquisa intitulada "Dimensões Analíticas do Fluxo de Informação na Trajetória do Usuário no Sistema Hospitalar: Análise do trabalho humano com ênfase em levantamento de indicadores de penosidade (sofrimento psíquico) de profissionais de emergência hospitalar". Esta pesquisa tem como objetivo compreender, de forma sistematizada, o trabalho humano nas ocupações relacionadas às instituições de saúde com ênfase na definição de indicadores 
mensuráveis de penosidade. O propósito final será a criação de intervenções que minimizem o sofrimento psíquico relacionado ao exercício profissional.

\section{Procedimentos:}

Você está sendo convidado (a) a participar de uma entrevista constituída de perguntas sobre como você percebe seu trabalho na emergência hospitalar. A entrevista será realizada nas dependências do setor de emergência. A entrevista será conduzida por um(a) pesquisador(a) devidamente treinado(a) que realizará a leitura dos itens para você.

\section{Riscos e inconveniências:}

Você poderá se sentir ansioso(a) e preocupado(a) frente ao conteúdo dos questionários. Em caso de qualquer necessidade, você poderá contatar um dos membros da pesquisa, que o(a) assistirá indicando locais para possível acompanhamento psicológico.

\section{Potenciais benefícios:}

As informações que você fornecer serão úteis para o avanço do conhecimento acerca do grau de sofrimento psíquico relacionado aos funcionários que atuam em serviço de emergência hospitalar, podendo beneficiar outras pessoas. Ademais, o desenvolvimento do conhecimento produzido por meio desta pesquisa resultará em estratégias de intervenção com vistas à prevenção do sofrimento psíquico decorrente do exercício da profissão.

\section{Informações Adicionais:}

Os dados fornecidos por você serão usados somente para o fim previsto neste projeto de pesquisa. As informações obtidas serão mantidas em lugar seguro e a identificação dos participantes só poderá ser realizada pelos pesquisadores. Caso o material venha a ser utilizado para publicação científica ou atividades didáticas, não serão utilizados nomes ou quaisquer outras informações que possam vir a identificá-lo.

Não haverá nenhum custo ao participante em qualquer fase da pesquisa. Do mesmo modo, não haverá compensação financeira relacionada à sua participação. 
Você terá total e plena liberdade para se recusar a participar bem como retirar seu consentimento, em qualquer fase da pesquisa.

Se você tiver alguma consideração ou dúvida sobre a ética da pesquisa, pode entrar em contato com o Comitê de Ética em Pesquisa da Secretaria Municipal de Saúde e Defesa Civil, pelo telefone 3971-1463 (horário comercial) ou pelos emails cepsms@rio.rj.gov.bre cepsmsrj@yahoo.com.br.

Assinando esse consentimento, você não abre mão de nenhum de seus direitos. Além disso, você não libera os investigadores de suas responsabilidades legais e profissionais no caso de alguma situação que lhe prejudique. A sua participação é inteiramente voluntária.

Uma vez aceitando participar desta pesquisa, você deverá se sentir livre para abandonar o estudo a qualquer momento, sem que isto afete o seu cuidado ou relacionamento futuro com esta instituição. $\mathrm{O}$ (a) investigador(a) deste estudo também poderá retirá-lo do estudo a qualquer momento, se ele julgar que seja necessário para o seu bem-estar.

Caso surja alguma dúvida quanto à ética do estudo, você deverá se reportar ao Comitê de Ética em Pesquisa envolvendo seres humanos - subordinado ao Conselho Nacional de Ética em Pesquisa, órgão do Ministério da Saúde, através de solicitação ao representante de pesquisa, que estará sob contato permanente, ou contatando o comitê de ética em pesquisa desta instituição, no telefone (21) 39711463. É assegurado o completo sigilo de sua identidade quanto à sua participação neste estudo, incluindo a eventualidade da apresentação dos resultados deste estudo em congressos e periódicos científicos.

Diante do exposto nos parágrafos anteriores eu,

,residente à (endereço)

concordo

em participar do estudo.

$\mathrm{Eu}$ fui completamente orientado (a) pelo pesquisador (nome completo de quem está aplicando o TCLE) que está realizando o estudo, de acordo com sua natureza, propósito e duração. Eu pude questioná-lo (a) sobre todos os aspectos do estudo. Além disso, recebi uma cópia da folha de informações para os participantes, a qual li, compreendi, permitindo-me plena liberdade para decidir acerca da minha espontânea 
participação nesta pesquisa. Depois de tal consideração, concordo em cooperar com este estudo, promovido pela Pontifícia Universidade Católica do Rio De Janeiro e financiado pelo Ministério da Saúde.

Estou recebendo uma cópia assinada deste termo.

Rio de Janeiro, I

Investigador:

Nome:

Data:

Assinatura:

Participante:

Nome:

Data:

Assinatura:

Responsável:

Nome:

Data:

Assinatura:

Este termo será assinado em 02 (duas) vias de igual teor, uma para o participante da pesquisa e outra para o responsável pela pesquisa.

\section{CONTATOS:}

\section{Pesquisadora responsável:}

Maracy Domingues Alves - Professora do Departamento de Psicologia da PUCRio. Rua Marquês de São Vicente, 225, Edifício Cardeal Leme, sala 201, Gávea, Rio de Janeiro. Telefone: (21) 3527 2073. Email: maracy.alves@ gmail.com

\section{Comitê de Ética em Pesquisa:}

Secretaria Municipal de Saúde e Defesa Civil, Rua Afonso Cavalcanti, 455 sala 710 - Cidade Nova, Rio de Janeiro, RJ. Telefone 3971-1463 (horário comercial). E-mails cepsms@rio.rj.gov.br e cepsmsrj@yahoo.com.br. 